\title{
Formação do Urbanismo em São PaUlo Como CaMpo deconhecimento E ÁREA dE ATUAÇÃo PROFISSIONAL
}

Maria Cristina da Silva Leme

Tese apresentada para Concurso de Livre-Docência Faculdade de Arquitetura e Urbanismo Universidade de São Paulo

\author{
São Paulo \\ Janeiro 2000
}

DEDALUS - Acervo - FAU

20200017054

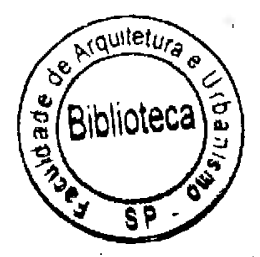


Aos meus pais, Maria Alice e Ruy, com muito amor.

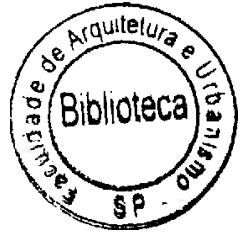




\section{INTRODUÇÃO}

O trabalho tem por objetivo descrever e analisar a formação do urbanismo em São Paulo como campo de conhecimento e de atuação profissional desde o final do século XIX , quando se inicia uma intervenção planejada na cidade , até o aparecimento de duas novas vertentes nos anos cinquenta

Este trabalho se insere em nossa trajetória de reflexão sobre o planejamento urbano no Brasil. No início da década de 70 investigávamos a eficácia dos planos diretores como instrumento de atuação do poder municipal. Esta análise refletia, em parte, a perplexidade dos urbanistas face ao número de planos elaborados e a não utilização destes documentos como instrumento de planejamento das administrações municipais que os haviam feito elaborar.

Na dissertação de mestrado ${ }^{1}$ estudamos os principais documentos de planejamento urbano para a cidade de São Paulo, no período entre 1930 e 1969, relacionado-os ao quadro politico e econômico federal, estadual e municipal.

Este estudo, assim como outros elaborados no mesmo período, partiam da constatação de uma crise do planejamento urbano e apontavam para a necessária revisão do papel a ser desempenhado por esse instrumento de atuação do Estado no urbano.

Neste período, do final dos anos 70 ao início dos anos 80 o descrédito dos planejadores em relação à atividade que exerciam pode ser atribuída ao fato de associarem este instrumento como inerente à forma autoritária do exercício do poder que havia se iniciado no Brasil com o golpe militar em 1964. Esta reflexão representava um ponto importante de inflexão nos estudos urbanos. Deixava-se de lado uma visão; até ali; Oprevalecente do caráter neutro da atuação do Estado, diferenciando-se o discurso das práticas de intervenção concreta.

\footnotetext{
1 Leme, Maria Cristina da Silva "Planejamento urbano em São Paulo 1930-1969"
} Dissertação de Mestrado FAU USP, 1982 
Entretanto como alertou Scherer ${ }^{2}$, na conclusão de sua tese, o fato de ter prevalecido nos vinte anos do govemo autoritário, a ideologia da técnica e da ciência como forma de legitimação do poder, levou a associação indiscriminada do planejamento como prática autoritária e repressiva. A autora observa que ao se negar um tipo determinado de planejamento acabava-se negando qualquer tipo de planejamento.

No processo de elaboração da tese de doutorado ${ }^{3}$ foram emergindo algumas categorias de análise que nos pareceram significativas para o estudo do planejamento urbano. Procurávamos fugir de certas posturas reducionistas e simplificadoras, que enfocavam as questões relativas à eficiência e eficácia do planejamento urbano como instrumento de atuação do Estado, enfocando principalmente o aspecto formal das práticas de planejamento institucionalizado; ou ainda, a postura de denúncia, que tem evidentemente importância política e ideológica, ao identificar o papel desempenhado pelo planejamento urbano, apenas como cortina de fumaça encobrindo interesses econômicos que estariam produzindo a cidade, mas que não avança para fundamentar e explicar as condições em que isto ocorre e que podem indicar os caminhos possíveis de mudanças.

Ao analisar o Plano de Avenidas 4 elaborado por Francisco Prestes Maia em 1930 procuramos encaminhar dois eixos de análise :o da lógica interna ao planejamento urbano e o das relações entre o planejamento urbano e as práticas concretas dos diferentes agentes (públicos e privados)que produzem a cidade. A escolha deste documento deveu-se ao fato de que ele é o único plano urbanístico que orientou a ação da administração municipal de São Paulo .Nesse sentido ele permitia uma análise privilegiada dos dois eixos propostos.

O primeiro eixo partia do estudo do conteúdo do plano e relacionava seus principais

\footnotetext{
2 Scherer, Rebecca "Descentralização e planejamento urbanono município de São Paulo" Tese de doutorado, FAU USP, São Paulo, 1987.

3 Leme, Maria Cristina da Silva "ReVisão do Plano de Avenidas Um estudo do planejamento urbano em São Paulo,1930" Tese de doutorado, FAU USP, 1990.

4 Maia, Francisco Prestes "Estudo de um Plano de Avenidas para São Paulo" São Paulo, Melhoramentos, 193
} 
aspectos(temas abordados, propostas de intervenção, recursos legais e financeiros para a implementação das propostas)com o pensamento urbanístico que teve influência na sua elaboração. $O$ segundo eixo de investigação consistiu na análise da relação entre o conteúdo do plano,(enquanto intenção de intervenção) e as práticas concretas de agentes (públicos e privados)que produziam a cidade no momento de elaboração e de implantação do plano. A articulação dos dois eixos de análise permitiu avançar na interpretação do significado e do alcance do planejamento urbano naquele momento histórico .

A partir da discussão das idéias expostas no doutorado foi se consolidando o interesse pela pesquisa sobre a formação do pensamento urbanístico em São Paulo. Questões exploradas na tese, como a influência das idéias de urbanistas paulistas e de urbanistas americanos e europeus para a formação do urbanismo paulistano ,se mostraram um ponto importante de diálogo com outros pesquisadores.

O contato com estes pesquisadores estimulou a formação de uma rede de pesquisa sobre a formação do urbanismo no Brasil .Formulada como um levantamento documental abrangendo as obras de urbanistas publicadas em livros e revistas especializadas; projetos e planos urbanos, a pesquisa permitiu identificar e reunir documentos que se encontravam esparsos em arquivos de dificil acesso como acervos particulares e seção de livros raros em bibliotecas públicas.

A adoção de metodologias comuns de levantamento e sistematização deste material permitiu avançar na reflexão teórica e metodológica sobre o conhecimento da história do urbanismo e do planejamento urbano a partir do aprofundamento das análises comparativas entre as oito cidades. Esta visão comparada e de conjunto imprimiu um novo olhar nas pesquisas que vínhamos desenvolvendo sobre São Paulo. Ao possibilitar a identificação das singularidades e dos eventos em comum estimulou a procura de interpretação dos processos que se davam em escala nacional.

No inicio dos anos noventa iniciava-se um processo de reflexão mais ampla sobre a história da cidade e do urbanismo como podia ser observado na realização dos Seminários de História Urbana . Havíamos identificado a passagem do interesse do 
presente ao interesse pelo passado quando elaboramos, junto com Regina Pacheco 5 ,um balanço sobre os referenciais teóricos na produção acadêmica de estudos urbanos dos anos oitenta. Levantávamos como hipótese explicativa para o desenvolvimento dos estudos históricos no campo do urbano no Brasil a necessidade da busca de nossas raizes como estratégia de conhecimento da formação da sociedade. Esta hipótese se contrapunha a levantada por Topalov 6 para a realidade francêsa segundo o qual o interesse pelos estudos históricos seria a expressão de uma despolitização da questão urbana.

Consideramos hoje que o recurso à pesquisa histórica representa uma fonte privilegiada de questionamento para a compreensão e reapropriação do presente. Esta convicção está na base dos estudos elaborados para a realização deste trabalho.

$\mathrm{Na}$ análise da formação do urbanismo em São Paulo utilizamos como recurso metodológico o estudo da palavra urbanismo, das trajetónas geográficas e profissionais dos urbanistas que aqui atuaram e das transferências e traduções dos saberes de urbanistas europeus e americanos

Procuramos estudar a trajetória da palavra urbanismo ${ }^{7}$. 0 estudo dos significados da palavra e das que a precedem e substituem permitiu avançar na identificação de diferentes períodos de constituição do campo de conhecimento e de atuação profissional.. Observa-se que a prática precede a formação do urbanismo enquanto área de conhecimento o que nos levou a formular a hipótese sobre a necessidade da organização de uma educação formal para legitimar uma pratica que vinha se fazendo junto ou sob o contrato de instituições públicas.

A fonte principal de consulta foram os textos escritos por engenheiros, arquitetos que

\footnotetext{
5 Leme, Maria Cristina da Silva, Pacheco, Regina V. “A questão fundiária, imobiliária e os serviços urbanos : conceitos e referenciais teóricos em teses e dissertações recentes" Revista Espaço \& Debates, no 28, São Paulo, NERU , 1989

6 ver sobre este tema Leme, Maria Cristina da Silva, Pacheco ,Regina V, 1989, opus cit

7 Este estudo se insere no estudo que vimos realizando no contexto da rede internacional Programa Les Mots de la ville. PIR Villes CNRS/MOST UNESCO, sob a coordenação, no Brasil da profa Maria Stella Bresciani.
} 
compõem o meio técnico e acadêmico que atua neste setor ,em São Paulo. $O$ abandono de uma palavra e a substituição por outra forneceu pistas importantes sobre as questões que estavam em circulação para formar este campo de conhecimento e de atuação profissional.

No início procuramos distinguir a palavra dos seus significados. Pesquisando nos dicionários portugueses do final do século XVIII as palavras derivadas do radical urbs vemos que estão associadas a cortesia, bons modos dos que vivem na cidade, em oposição à rusticidade e grosseria dos que vivem no campo. No século XIX a palavra vem associada , também, à idéia de civilização. ${ }^{8}$

Esta relação entre um modo de vida caracterizado por um comportamento e o espaço físico onde estas novas formas de sociabilidade se desenvolvem ficam mais explícitas quando lemos as explicações do engenheiro catalão Ildefonso Cerdà sobre as origens da palavra urbanização .Quando ele cunha, em 1863, a palavra deriva-a de "urbs, contração de urbum que designava o arado, instrumento com o qual os romanos traçavam o círculo que deveria conter o povoado que eles iriam fundar. Denotava e exprimia tudo que podia conter o espaço circunscrito pelo sulco aberto com o auxílio dos bois sagrados." 9

O termo urbanização, para Cerdà designava "o conjunto de ações tendendo a agrupar as construções e a regularizar seu funcionamento como conjunto de princípios, doutrinas e regras que é necessário aplicar para que as construções e seu agrupamento longe de reprimir, enfraquecer e corromper as faculdades físicas morais e intelectuais do homem social, contribuam a favorecer seu desenvolvimento assim como melhorar o bem estar individual e o bem público 10".

8 Conforme Silva ,Antônio de Moraes Dicionário da lingua portuguesa Lisboa , Lacerdina, 1813

Urbanidade: s. f. A cortezia, e bom termo, os estilos de gente civilizada e polida, civilidade, polícia.

Urbanizar: v. at. Fazer urbano, civilizar.

Urbano: Dotado de urbanidade, conforme os termos da urbanidade, trato urbano.

9 Cerdá Ildefonso 'La théorie génerale de 1 'urbanisation"Paris Ed du Seuil , 1979 ,p 82 (traduzido do francês )

10 Cerdá, opus cit , p 82,( traduzido do francês) 
Cerdà ao escrever a Teoria Geral da Urbanização tinha como objetivo configurar um campo conceitual que servisse de referência à prática de projeto e construção planejada das cidades que se constituía com vigor naquela época $O$ seu plano para a extensão da cidade de Barcelona é uma das referências mais importantes no campo do urbanismo moderno.

Vemos, portanto, que nos meados do século XIX constituía - se um vocabulário especializado que correspondia a um esforço de regulamentação para a intervenção nas cidades . Cerdà pretendia que esta regulamentação tivesse em vista não apenas o individuo mas o bem comum., ideal que aparecerá crescentemente associado aos discursos do urbanismo.

O uso do radical urbs para designar o campo de conhecimento e de atuação sobre o urbano é restrito a alguns países de língua latina 11 . $\mathrm{O}$ fato de terem sido cunhadas diferentes palavras com significado semelhante são indícios da forma como se constituiu este campo de conhecimento. Conforme observa Coudroy de Lille ${ }^{12}$ "entrar através das palavras nas problemáticas do planejamento urbano ${ }^{13}$ permite principalmente não confundir duas ordens de realidade. Se as noções viajam no tempo e no espaço, se os conceitos são instrumentos feitos para serem utilizados, as palavras não existem sem as situações em que são enunciadas e utilizadas: elas estão vinculadas ao seu contexto".

Ele observa na relação de diferenciação entre as palavras e seus significados que "as

11 Urbanismo nos paises de lingua espanhola e portuguesa , urbanisme na França, urbanistica na Itália. Em outras linguas são outras as palavras para designar o conhecimento e a profissão da pratica de intervenção sobre o urbano. Town planning , na Inglaterra, City planning nos Estados Unidos; Stadtebau na Alemanha são alguns exemplos .

12 em seu trabalho apresentado no Colóquio Les Mots de la Ville em 1997 e publicado na Revista Urbanisme janeiro de 1999 ,ele apresenta uma serie de observaçôes de ordem metodológica que muito esclareceram a organização deste texto.

13 aménagement urbain no original não tem correspondência no portugues. A tradução seria ordenamento, organização.É uma expressão que aparece para explicitar, no início do século, o conteúdo dos planos urbanos para as cidades francesas - plan d'aménagement ,

embelissement e extension urbain. O plano do urbanista francês Donat Alfred Agache para a cidade do Rio de Janeiro ,em 1927, tem o título traduzido para o português como Plano de remodelação, extensão e embelezamento. 
palavras sobre o urbanismo, antes mesmo da palavra urbanismo têm um importante e especifico papel: o de instaurar legitimidade - jurídica ou ideológica - à intervenção urbana."14.

Em cada país o campo de conhecimento do urbanismo não é autônomo ,mas se estrutura junto a outros campos de conhecimento: a engenharia, a arquitetura ou a sociologia ,como resposta a demandas políticas e sociais.

Na Alemanha inicia-se em 1889 o ensino de urbanismo na Escola Politécnica de Charlotten Bourg em uma cadeira denominada 'A arte do engenheiro municipal'15. A construção política do Estado na Alemanha na metade do século XIX se faz conferindo um importante papel ao nível local de poder. O urbanismo se desenvolve na medida que cresce o reconhecimento das funções do poder local .A partir das experiências de gestão é produzida uma extensa literatura de publicações especializadas como a revista Der Stadtebau e manuais de urbanismo. Estes manuais escritos por figuras públicas como Joseph Stubben e Joseph Baumeister tiveram larga repercussão nos outros países da Europa divulgando normas e modelos urbanísticos. Nestas experiências de gestão local na Alemanha estariam uma das origens dos planos reguladores e seriam portanto a resposta do urbanismo no sentido de uma racionalização do desenvolvimento das metrópoles do tipo capitalista.

Analisando as formações em urbanismo, Marques 16 observa que segundo a perspectiva da sociologia das profíssões o movimento de autonomização de uma profissão tem como componente essencial uma formação especifica. Nesta perspectiva o papel do ensino superior é de fornecer os conhecimentos e manter o controle do acesso à profissão.

No mesmo sentido, relacionando a noção de autonomia da profissão ao

\footnotetext{
14 Coudroy de Lille, opus cit, p 59

15 Carmem Portinho engenheira e ativa urbanista carioca faz um rápido relato sobre o desenvolvimento do ensino do urbanismo .

16 Marques, Sonia , "les Professions de l'urbanisme au Bresil"thèse de doctorat École des hautes Études en Sciences Sociales, s/d
} 
reconhecimento social e ao necessário desenvolvimento de uma área de conhecimento o sociólogo francês Christian Topalov observa: "A ciência urbana ao se constituir no início do século está desde logo ligada a uma prática, o planejamento urbano. Ela the fornece sua legitimidade, seus conceitos, sua metodologia seus especialistas" 17 . Entretanto, esta nova prática profissional tanto nos países europeus como nos Estados Unidos, segundo o autor, se formava no contexto da reforma social procurando definir uma nova ordem social mais produtiva e menos conflituosa.

Uma primeira questão que nos colocamos neste trabalho, portanto, se refere ao meio em que se organiza o conhecimento e a prática profissional. Observa-se que em outros países a prática precede a formação institucionalizada em cursos de urbanismo. Ela é acompanhada pela organização em associações profissionais e a publicação de revistas especializadas. Poderiamos, portanto, formular a hipótese sobre a necessidade da organização de uma educação formal para legitimar uma pratica que vinha se fazendo junto ou sob o contrato de instituições públicas .

Sendo o urbanismo um conhecimento formulado tendo em vista uma pratica de intervenção sobre o urbano, esta relação entre o saber e a pratica profissional se faz de diferentes forma. Distingui-las permite ,também, diferenciar linhagens de urbanismo quanto o meio profíssional e intelectual em que se inserem e na sua relação com o Estado.

No Brasil ,como nos outros países, o ensino do urbanismo não precede a prática urbanística mas vem a posterior com claro indicio de a legitimar. Constitui -se a partir - das experiências de intervenção na cidade que se fazem no terreno da legislação urbanística, do saneamento urbano e dos projetos de abertura e extensão viária. $O$ ensino do urbanismo tem início dentro dos cursos de engenharia e o seu conteúdo reforça o trabalho profissional dos engenheiros arquitetos! Na Escola Politécnica, em São Paulo, aparece como disciplina apenas ao final da década de 20.

17 Topalov , Christian, "Os saberes sobre a cidade : tempos de crise? "Revista Espaço e Debates no $34, \mathrm{p} 30$ 


\begin{abstract}
A palavra urbanismo é recente e as primeiras referências aparecem em textos elaborados por engenheiros nos primeiros anos do século XX. Antes de ser cunhada ,a palavra que a precede é melhoramento urbano. Procuramos neste trabalho identificar o momento em que a nova palavra começa a ser utilizada, seguir o seu percurso, a convivência e a concorrência entre palavras, as formas de adaptação, a institucionalização e, enfim, a substituição do antigo pelo novo.
\end{abstract}

Definimos urbanismo como a formulação de um conhecimento e a formação de uma prática profissional de intervenção sobre o espaço urbano.

Neste trabalho procuramos diferenciar a palavra urbanismo de seus significados, diferentes no tempo e segundo quem a emprega. É um dos elementos que ajudam a identificar as diferentes vertentes de urbanismo que se configuraram no Brasil. Seguindo esta linha de interpretação seria possível identificar nos grandes temas que mobilizaram os meios em que se movimentaram as vertentes de urbanismo para perceber as semelhanças e diferenças entre elas. Neste sentido o estudo das palavras fornece importantes pistas para identificar grupos, estratégias de legitimação, rivalidades, e continuidades no tempo.

$O$ fato de diferentes vertentes do urbanismo compartilharem as mesmas palavras porém com significados diversos auxilia também na compreensão da formação destes campos intelectuais ${ }^{18}$. Identificar as questões que mobilizaram os urbanistas em cada período permite entender os limites e alcances deste campo de atuação.

Ao realizar a pesquisa para o doutorado um dos aspectos estudados foi, o que denominamos na época, a influência das idéias de urbanistas estrangeiros na formulação das propostas dos urbanistas paulistanos.

18 Bourdieu atribue uma relação importante entre os sistemas de ensino e sistemas de pensamento. "Assim como os lingüistas recorrem ao critério da intercompreensão a fim de determinar as áreas linguísticas , tambem poder- se- ia determinar áreas e gerações intelectuais e culturais, através de levantamento dos conjuntos de questões que definem o campo cultural de uma época" Bourdieu, Pierre "A economia das trocas simbólicas", São Paulo, Editora Perspectiva, 1974 p 206, 207 
Abria-se naquele momento um campo importante de pesquisa. A identificação das citações e a leitura das obras de origem possibilitou, inicialmente, perceber o caráter inovador da conferência pronunciada pelo engenheiro português Victor da Silva Freire, em 1911, a seus alunos da Escola Politécnica como inicio de uma reflexão sobre o urbanismo em São Paulo. Permitiu ainda constatar não apenas a circulação de modelos urbanísticos mas a forma como os urbanistas paulistanos se apropriavam e os adaptavam a seus interesses. É exemplar neste sentido a combinação de dois modelos utilizado por Francisco Prestes Maia para propor o sistema radial perimetral para São Paulo utilizando ao mesmo tempo o modelo de Eugène Hénard e o de Joseph Stuben.

Permitiu ainda identificar, na elaboração do Plano de Avenidas, a importância que assumiu o urbanismo americano, tanto no modelo adotado, priorizando o transporte sobre pneus em relação ao transporte sobre trilhos, nas questões referentes a alternativas na captação de recursos financeiros para a realização de obras_e na definição da formação de uma especialidade da engenharia - a engenharia municipal.

O prosseguimento de estudos e pesquisas e a formação de uma rede internacional de pesquisa sobre urbanismo ${ }^{19}$ permitiu avançar na percepção sobre as formas assumidas pela circulação de idéias e o papel que assumem na formação do urbanismo em cada cidade.

Abandonada a noção de influência foi substituída pela de transferência e tradução para evidenciar as formas de apropriação dos saberes e práticas profissionais. Em seminário realizado em 1993 pelo IPPUR foi proposta uma nova noção- a de ressonância 20 - significando tratar-se de um terreno de trocas de experiências em que todos os profissionais envolvidos modificam-se através destes contatos.

19 Christian Topalov, Catherine Bruant, Jean Pierre Frey; pesquisadores latino americanos Alicia Novick, Oscar Bragos, Juan Jose Martin e outros pesquisadores brasileiros Luiz Cesar de Queiroz Ribeiro, Robert Pechman, Maria Stella Bresciani,Marisa Carpintero, Margareth da Silva Pereira no estudo das transferências e traduções de saberes entre os urbanistas brasileiros, latino americanos e franceses.

20 Carlos Roberto Monteiro de Andrade no seminário IPPUR CSU propõs esta noção como método de análise da rede de pesquisa. 
Neste trabalho estudamos as duas noções: a de transferência e tradução e também a de ressonância. A diferenciação das formas de contato fornecem informações sobre a legitimidade conferida na transmissão de idéias. Procuramos esclarecer os motivos que mobilizaram os urbanistas europeus a cruzar o Atlântico 21

Observamos o impacto da experiência em um outro continente na produção de Le Corbusier após a sua viagem à América do Sul em 1929. Mais significativa é a observação de Antonio Candido sobre a influência das obras de Josué de Castro na formulação do conceito de desenvolvimento e solidariedade pelo padre dominicano Joseph Lebret

Na formação do urbanismo no Brasil , como disciplina e como campo de trabalho profissional, constata-se a importante influência das concepções urbanísticas internacionais. Esta influência pode ser percebida na leitura de documentos, artigos publicados nas revistas especializadas, livros, planos e projetos urbanos. Estes documentos manifestam um conhecimento atualizado da produção científica do período, reproduzem as idéias, as polêmicas e adotam ,freqüentemente, os modelos elaborados pelos urbanistas estrangeiros.

As formas pelas quais se deram os contatos entre os urbanistas brasileiros e os urbanistas franceses, ingleses, americanos foram diferenciadas ,tanto para os urbanistas brasileiros enquanto recepção e assimilação de conhecimento, como para os urbanistas estrangeiros enquanto reconhecimento internacional e abertura de um campo de atuação profissional.

Os contatos iniciais se deram pessoalmente nos congressos e exposições internacionais e também pelo contato com as idéias pela leitura de livros e artigos publicados nas revistas especializadas.

$21 \mathrm{O}$ estudo em arquivos e acervos que realizamos em duas viagens à Paris, França permitiu ao consultar as obras originais dos urbanistas citados um melhor entendimento sobre a formação da cultura urbanística francesa e identificar com maior precisão as traduções realizadas por urbanistas paulistanos. Permitiu ainda desfazer equívocos sobre a autoria e originalidade das idéias. 
Verificamos que a vinda de alguns urbanistas franceses ao Brasil se deu inicialmente para a realização de conferências. Deste primeiro contato, em alguns casos ,as relações evoluíram para a contratação dos serviços profissionais como consultor ou como responsável por projeto urbanístico ou planos urbanos.

A segunda forma de circulação de idéias se fazia através da leitura dos textos escritos e apresentados em congressos internacionais e dos tratados urbanísticos. Nas bibliotecas pessoais de Anhaia Mello e de Prestes Maia, a primeira doada a FAUUSP e a segunda formando o acervo da Biblioteca Municipal Kennedy, existem as principais obras de urbanistas alemães, franceses, americanos, ingleses adquiridas logo em seguida a data de publicação.

A presença para apresentação de trabalho ou representação oficial nos congressos internacionais foi rara. Até a década de vinte temos conhecimento da participação do engenheiro Victor da Silva Freire no Congresso do Royal Institute of Architects em 1910 em Londres, no congresso Internacional e Exposição Comparada das Cidades realizado em Gand em 1913 ,quando foi eleito para o conselho diretor pela Union internationale des villes, indicação que ele atribui ao fato de ser o único representante brasileiro presente. O engenheiro Francisco Satumino de Brito apresenta o trabalho Le tracé sanitaire des villes no congresso Comment reconstruire nos cités détruites, em 1916.

A terceira forma, mais rara, mas também importante em termos de transmissão foi a realização de cursos de urbanismo. $O$ arquiteto carioca Atilio Correia Lima fez o curso de urbanismo no Institut d'Urbanisme de l'Université de Paris .Formou-se em 1930 com uma tese sobre a cidade de Niteroi,com o título Plan d'Aménagement, d'embelissement e d'extension de la ville de Niteroi tendo o arquiteto Henri Prost como diretor de tese.

$\mathrm{Na}$ correspondência do arquiteto Louis Bonnier, na pasta referente ao seu trabalho no Institut d'Urbanisme de l'Université de Paris depositada no Arquivos do Institut Français d'Architecture encontramos a referência ao projeto de tese de um aluno brasileiro, D. A .Ribeiro. O conteúdo deste trabalho era a proposta de uma futura 
capital a instalar no planalto central do Brasil. Entretanto este aluno não constava da lista de formados pelo Institut d'Urbanisme de Paris.

Destacamos a importância desta experiência de formação em urbanismo na França pois no caso de Atílio Correia Lima ela foi seguida pela introdução da disciplina de urbanismo no Rio de Janeiro em 1933, na Escola de Belas Artes.

Os princípios do urbanismo modernista são introduzidos no meio acadêmico a partir das conferências realizadas por Le Corbusier em 1929, no Rio de Janeiro e no Instituto de Engenharia em São Paulo. Mas o objetivo da viagem de Le Corbusier ao Brasil, como se evidencia em sua correspondência ${ }^{22}$, era desenvolver projetos urbanos. Fazer um projeto para a cidade do Rio de Janeiro, mesmo que isso implicasse na despedida sumária de seu compatriota Agache. Mas , a ambição de Le Corbusier não se limitava à proposta de transformação da cidade existente .Desde que havia sido informado por Blaise de Cendrars da aprovação pelo Congresso de verbas para uma nova capital do Brasil, Planaltina, seu interesse em realizar esta obra é evidente na correspondência que envia a seus amigos brasileiros. Ele declara, mais tarde, que não se deslocaria toda a distância que separa os dois continentes para dar apenas conferências, o seu interesse era desenvolver projetos.

As redes de relações que lhes permitiram os contatos com o Brasil são bastante diferentes entre Joseph Bouvard, Le Corbusier, Donat Alfred Agache e Joseph Lebret e denotam que fazem parte de meios urbanísticos diferentes, argumento que procuramos desenvolver neste trabalho.

22 Envia cartas a Oswaldo Costa .Em carta datada de 22 de abril menciona "un sujet délicat : les grands travaux de Rio de J. Délicat parce qu'il y a en place au Rio un confrère: Agache(...) Il Faut être de la grand ère machiniste qui commence .Et les villes du Sud Amérique sont celles au monde qui sont arrivés aujourd'hui à l'heure de son destin .resterez vous au projets dans un style 1925 bouffon? Je dis BOUFFON" FLCDossier A311 Voyages en Amerique Latine, II 1936,B São Paulo -Correspondencia 1929-1930..Em carta de 12 julho de 1930,ele argumenta"Ecoutez, je serai heureux pour l'histoire de ma carrière que mon voyage dAmérique me fournisse l'occasiond'un oeuvre de grande architecture ou d'urbanisme .Je mourrais comme les autres - bientôt.J'ai travaillé pendant 25 ans a faire les racines. Nos pays ici sont trop vieux J'ai un besoin de paternité Je suis a 1 'age où il faut produire. Vous autre de Brésil donnez moi cette occasion"FLCVoyages en Amerique Latine, II 1936,B Så Paulo -Correspondencia 19291930. 
Os engenheiros e arquitetos, principalmente formados no Rio de Janeiro e em São Paulo serão chamados para desenvolver projetos e dar consultorias em outras cidades. Difunde se desta forma um saber técnico no campo do saneamento e repetem-se modelos de organização do sistema viário e de transportes .

Este trabalho está estruturado em três capítulos. No primeiro capítulo procuramos estudar a gênese do urbanismo em São Paulo e a forma como se estrutura no ensino da engenharia, na formação de órgãos de representação de classe, na criação de revistas especializadas e na organização do serviço público estadual e municipal .

Em um segundo momento, objeto de estudo do segundo capítulo, o urbanismo passa a designar um campo de conhecimento articulado a uma forma de intervenção planejada na cidade. Procuramos mostrar que a visão de cidade, como objeto de intervenção, inicialmente restrita à área central amplia-se gradativamente. São elaborados os planos de conjunto, principalmente planos viários para a totalidade da área urbanizada. Acompanha este movimento uma percepção de uma necessidade de atuação crescente do Estado, que deve assumir a responsabilidade pela execução de obras e a regulação e regulamentação das atividades de produção imobiliária e de serviços urbanos.

No terceiro capitulo mostramos que duas novas vertentes de urbanismo vêm se somar à que havia formado na engenharia, em São Paulo. A primeira estabelece um vínculo entre o urbanismo e a arquitetura, inicialmente na Escola Nacional de Belas Artes, no Rio de Janeiro, e em outras cidades, inclusive São Paulo, com a autonomização do ensino da arquitetura em relação à engenharia no final da década de quarenta. As duas viagens de Le Corbusier ao Brasil em 1929 e em 1936 influem pra configurar o meio. Os projetos premiados no concurso de Brasilia demonstram fortemente a difusão do ideário do urbanismo modernista entre os arquitetos brasileiros .

A segunda vertente aparece na formação dos escritórios da SAGMACS como resultado da penetração do Movimento Economia e Humanismo, pelo padre dominicano Joseph Louis Lebret nos meios políticos católicos, em São Paulo e no Recife . 
As três vertentes não são isoladas, porém se estabelecem e legitimam em meios diferentes. A tese que procuramos desenvolver neste trabalho é que para uma compreensão dos rumos que assume o planejamento urbano a partir da década de sessenta esta diferenciação é fundamental. 


\section{CAPÍtulo I}

\section{Melhoramentos URbanos:Praticas de INTERVENÇÃo PlanEJada NA CIDADE}

Neste capítulo procuramos estudar a gênese do urbanismo em São Paulo e a forma como se estrutura no ensino da engenharia, na formação de órgãos de representação de classe , na criação de revistas especializadas e na organização do serviço público estadual e municipal .Como observamos na introdução deste trabalho, o estudo das palavras pode nos oferecer pistas sobre a formação e as transformações de um campo de conhecimento. A palavra urbanismo só começa a ser utilizada a partir da década de dez e penetra gradualmente no meio técnico local substituindo a palavra melhoramento.

Iniciamos estudando o significado que assume a palavra melhoramento nas diferentes formas e momentos em que é utilizada, tanto quando designa uma forma de intervenção do poder público, como quando nomeia um artigo publicado em revista especializada ou um relatório de governo.

Ao estudar as trajetórias profissionais dos engenheiros que atuaram neste período, em São Paulo, observamos que ocupam inicialmente os postos de trabalho abertos pelas novas frentes de investimento dos capitais acumulados na exportação de café: construção de ferrovias, formação de companhias de abastecimento de água, transporte público, iluminação.

Observamos ainda a imbricação da formação do ensino de urbanismo na Escola Politécnica e a estruturação dos quadros na Prefeitura Municipal e no Governo do Estado nos setores ligados às obras públicas. Estes engenheiros ocuparam cargos de chefia no serviço público e eram também os responsáveis pelas cátedras na escola. Esta dupla inserção reproduzia-se nos cargos diretamente subordinados e que ,muitas vezes, substituiam os titulares nos afastamentos e depois nas aposentadorias.

Configura-se, desta forma, a transmissão de um conhecimento técnico e uma forma de administrar a cidade. 
Salientamos duas questões na comparação entre as gerações de urbanistas que atuaram no ensino e na administração publica em São Paulo. Em primeiro lugar é a relação que estabelecem com as elites políticas e econômicas locais. Observamos diferenças importantes nas formas de participação política no legislativo e no executivo. Neste período a primeira geração por ocupar os principais cargos da estrutura administrativa municipal é responsável pela configuração do setor de urbanismo em temos de áreas de atuação. Veremos ao analisar as trajetórias profissionais destes engenheiros que é possivel relacionar o conhecimento técnico que detinham às mudanças nas propostas de regulação : legislação urbanística e tributação.

A qualidade dos projetos e planos urbanísticos elaborados demonstram que estes engenheiros estavam sintonizados com os conhecimentos técnicos em obras de infraestrutura e serviços urbanos, os mais atualizados, como pode ser observado nos projetos de canalização do rio Tietê. Detinham uma cultura urbanística onde estava presente a preocupação com o resultado estético .

Por outro lado, os limites desta atuação modernizadora na cidade são evidentes quando se analisa o âmbito dos projetos realizados. Observa-se que estes limites estão relacionados à imbricação de interesses com empresas imobiliárias como a City of São Paulo Improvements and Freehold Land Company Limited e empresas concessionárias de serviços públicos como a Cia Light and Power.

No final do século XIX, uma demanda crescente pelo engenheiro nos serviços de obras pode ser observada na estrutura administrativa da prefeitura de São Paulo', Destacamos dois momentos deste processo : a criação em 1896, da Comissão Técnica de Melhoramentos da Cidade, três anos depois, é finalmente criada a Seção de Obras, transformada em Departamento logo em seguida. Estavam dadas as bases para uma atuação mais coordenada na cidade.

1 Conforme informações sobre a estrutura e composição tecnica da prefeitura de São Paulo de 1892 a 1947 por José Geraldo Simões Jr em seu TGI , FAU USP, 1981. 


\section{A palavra melhoramento urbano}

No Brasil, desde os meados do século XIX, a palavra melhoramento urbano designava , tanto a formação de comissões para uma ação planejada ,como toda e qualquer intervenção em obras de saneamento ,abertura de praças, alargamento e extensão de vias. Esta relação entre a ação planejada e a prática de intervenção se fazia regulamentada pela Câmara .

Em 1860, Janice Theodoro da Silva identifica ,na leitura das Atas da Câmara de São Paulo, as primeiras referências ao processo de planejamento ,quando se exige a elaboração de uma "planta da Cidade e planos de construção das casas traçando as ruas e praças que deve ter a cidade sua direção e dimensões, as que devem ser alargadas, alinhadas ou conter unicamente casas de sobrado, afin de que desde então a concessão de licenças para a construção de predios em terrenos actualmente descampados, ou que por demolição vierem a sêl-o a Camara municipal se regule pela dita planta, negando a licença , sempre que o terreno for preciso para espaçar ou alinhar uma rua ou praça , e desapropriando-o ou no caso contrário concedendo a licença de ser a construção segundo o referido plano, de modo que gradualmente, e no decurso dos annos se consiga o aformoseamento da Cidade pelas desapropriações ou construções que forem se realizando"2.

Três anos mais tarde ,a atividade de planejar a cidade já é diretamente associada à palavra melhoramentos. Segundo Simões Jr, é por iniciativa do vereador João Mendes de Almeida proposta à Câmara a criação de uma comissão que teria como objetivo a organização de um Plano Geral de Melhoramentos. Este plano amplia as antigas funções da Câmara incluindo, por exemplo "a edificação nas margens da Várzea do Carmo de longas praças e boulevards arborizados até o Cambuci e a canalização retilínea do Rio Tamanduatei"3.

2 Atas da Camara 19 de julho de 1860 , apud Silva , Janice Theodoro "São Paulo 1554 1880 Discurso Ideológico e organização espacial" São Paulo, Editora Moderna , 1984, pp $147-148$

3 Simões Jr José Geraldo "O Setor de Obras Públicas e as origens do urbanismo na cidade de São Paulo" dissertação de mestrado , EAESP FGV , 1990, p 37 Simões Jr observa nãoter encontrado nos anos seguintes referência à atuação desta comissão nas Atas da Câmara. 
A racionalidade da ação pública associada à idéia de previsão da realização das obras se faz progressivamente e de forma extensiva no espaço. $O$ engenheiro João Pereira Ferraz , como diretor da Comissão Técnica de Melhoramentos da Cidade , propõe ,em 1897 ,a carta Geral da Cidade com o esboço do planejamento das obras públicas a serem executadas a médio e longo prazo ${ }^{4}$.

"Melhoramentos de São Paulo" é o título do artigo do engenheiro Victor da Silva Freire publicado em 1911 pela Revista Politécnica que identificamos como o texto inaugural na história da formação do pensamento urbanístico paulistano.

"Não é uma questão actual no estricto sentido da palavra, a dos melhoramentos de São Paulo. É a phase actual de uma questão permanente, a de acudir às necessidades do crescimento da cidade"5. Com este artigo Victor Freire incorpora ao ideário urbanistico paulistano as questões que mobilizavam os meios intelectuais do urbanismo moderno na Europa e nos Estados Unidos : a salubridade, a extensão e a estética.

Aborda a questão estética da forma urbana ao defender as posições do urbanista austríaco Camillo Sitte, trazendo o debate de duas posições antagônicas quanto ao projeto de desenho das cidades: a simetria dos traçados nascidos na prancheta e a irregularidade revalorizada do traçado histórico das cidades. A questão da salubridade urbana é introduzida através da discussão do papel dos espaços livres na saúde das populações. A sua solução para resolver o problema do sistema viário na área central inclui resguardar o vale do Anhangabaú como parque da cidade.

$\mathrm{Na}$ cidade, "os melhoramentos "que eram realizados pelo governo provincial passam a ter, no recém criado poder municipal ,uma nova instância de atuação político administrativa. Até as primeiras décadas do século XX, face à pequena capacidade de investimento da prefeitura permanece uma ambigüidade na atribuição de poderes

4 Idem Simões Jr, 1990, opus cit ,p 67

5 Freire Victor da Silva "Os Melhoramentos de São Paulo", Revista Politécnica, no 33 ,1911, p 92 
entre o governo estadual e municipal. Um exemplo é a disputa que envolve a Secretaria da Agricultura do Estado e a Diretoria de Obras Municipais da Prefeitura com projetos concorrentes para a reformulação do sistema viário do Vale do Anhangabaú.

A percepção de um conhecimento que se pretende universal vai aparecer nos textos escritos por urbanistas paulistas - a idéia de previsão inerente à atividade de planejar a cidade apoiava-se no princípio de que o porvir de uma cidade nos trópicos é inexoravelmente o mesmo de uma cidade européia., aplicando-se, portanto o mesmo conhecimento a realidades tão intensamente diferentes. No artigo, Freire propõe que se elabore um plano para a cidade adotando uma posição de previsão face aos problemas que cidades do porte de Paris e Londres já apresentavam. Entretanto, a cidade neste momento é ainda uma abstração e toda atenção tanto do governo estadual como da prefeitura se dirigia apenas para a resolução dos problemas na área central da cidade.

Nos textos técnicos, a palavra melhoramento continua a ser utilizada, convivendo com os termos urbanismo e planejamento urbano, até os anos cinquenta. Seu significado se mantém no tempo. Designa sempre práticas de intervenção planejada do poder local .O título "Grandes melhoramentos de São Paulo" é utilizado pelo engenheiro João Florence de Ulhôa Cintra e Francisco Prestes Maia em uma série de artigos que publicam no Boletim do Instituto de Engenharia de 1924 a 1926 e que constituem o esboço do famoso Plano de Avenidas ${ }^{6}$. É também o título do relatório de governo que Prestes Maia apresenta como balanço dos anos frente à prefeitura de São Paulo, em 1945.

Em 1951, o plano contratado pela prefeitura de São Paulo ao IBEC International Basic Economic Corporation tem o nome de Programa de Melhoramentos Públicos para a cidade de São Paulo- Program of Public improvements. 0 relatório de um estudo de seis meses coordenado pelo urbanista americano Robert Moses constituia-se

6 "O Estudo de um Plano de Avenidas para a cidade de São Paulo" é de autoria apenas de Francisco Prestes Maia e publicado em 1930 pela Editora Melhoramentos de São Paulo 
em um série de orientações para um plano viário, para a cidade . Reforça, portanto esta associação entre a palavra melhoramento e uma prática profissional concreta na cidade.

\section{A formação do meio urbanístico no ensino e no exercício da profissão.}

Em São Paulo, o ensino do urbanismo não precede a prática urbanística mas vem a posteriori com claro indício de a legitimar. Constitui -se a partir das experiências de intervenção na cidade que se fazem no terreno da legislação urbanística, do saneamento urbano e dos projetos de abertura e extensão viária. 0 ensino do urbanismo tem início no curso de engenheiro civil e engenheiro arquiteto e o seu conteúdo reforça o trabalho profissional que já vinha sendo desenvolvido principalmente nos órgãos de administração pública. Na Escola Politécnica aparece denominando uma disciplina apenas ao final da década de 20 , no curso de engenheiro arquiteto.

A criação do curso de engenharia, em São Paulo, é um produto da consolidação da República e da descentralização político - administrativa. Se constitui em resposta aos interesses econômicos conflitantes da agricultura e da industria emergente, na constituição da estrutura político administrativa municipal e na combinação do conhecimento do controle sobre o território com as formas de intervenção para a modernização das cidades.

O antecedente ao curso de engenharia em São Paulo é o Gabinete Topográfico, estabelecimento criado pela lei provincial $n^{\circ} 10$ de 24 de março de 1835 e que tinha como principal finalidade uma "escola para estradas". O gabinete teria funcionado de outubro de 1836 a março de 1838 , reaberto em 1840 e voltado a funcionar em 1842. Quatro anos mais tarde, perde a autonomia e é anexado à Diretoria de Obras.

Campos Neto ${ }^{7}$ observa que a iniciativa da criação do Gabinete pelo presidente da

7 Campos Neto, Candido Malta "Os rumos da cidade : urbanismo e modernização em São Paulo"Tese de doutoramento, FA USP, 1999, 2vol , p 51 
provincia Rafael Tobias de Aguiar, com origem no Partido Liberal tinha como objetivo reforçar a autonomia de São Paulo em relação à centralização do poder monárquico na corte. A formação de especialistas no setor de obras públicas, em especial na abertura de estradas, reforçaria as ligações entre a cidade e os centros produtivos.

Também a lei de criação da Diretoria de Obras representava a introdução de padrões atualizados de racionalidade e controle em termos técnicos e administrativos. Estas iniciativas tiveram pequena duração. Em 1849 , as duas instituições haviam sido extintas definitivamente o que poderia indicar, como observa o autor, uma resistência à nova categoria profissional dos engenheiros que começa a atuar na cidade.

A Escola Politécnica inicia suas atividades em 15 de fevereiro de 1894. Em 1896 ,começa a funcionar a Escola de Engenharia Mackenzie e o Liceu de Artes e Ofícios começa a ser reorganizado em 1895. Pelo primeiro regulamento da Politécnica,em agosto de 1893 ,eram criados os cursos de engenheiro civil, industrial e agrícola. .Em 1894 , o $2^{\circ}$ regulamento criava também o curso de engenheiro arquiteto ${ }^{8}$. O primeiro regulamento previa além das cadeiras sob responsabilidade de professores formados, aulas ministradas por profíssionais não necessariamente formados, contratados por dois anos ${ }^{9}$.

A criação desta instituição combinava o ensino teórico à pratica profissional, em campos bastante diferentes como o setor de construção civil ,em franca expansão no final do século, a agricultura e a industria ${ }^{10}$. A existência desde o início de um curso de engenharia industrial é uma das especifícidades da Politécnica

8 conforme Ficher, Sylvia "Ensino e profissão : o curso de engenheiro- arquiteto da Escola Politécnica de São Paulo" Tese de doutoramento Departamento de História FFLCH USP, 1989

9 Prestes Maia $s^{\wedge}$ Zerá uma das exceções.Formado ,deu aulas de desenho arquitetônico e esboço do natural de 1924 a 1937.Em 1937 é publicado um decreto proibindo o acumulo de cargos. Neste momento, ele deixa o ensino e opta pelo trabalho no Departamento de Obras Públicas, DOP.

10 O curso com maior procura era o de engenharia civil. O de agricultura se separa da Politécnica em 1902 com a criação da Escola Superior Agrícola de Piracicaba. O industrial é pouco procurado se transforma em curso de engenharia mecânica que, na década de 50 , se desdobra em engenharia de produçã 
paulistana 11 .Embora menos estruturado do que as outras formações denota o avanço dos novos interesses econômicos presentes em São Paulo.

A estrutura didática compreendia um curso fundamental com um ano preliminar e dois de curso geral e em seguida os cursos especiais de engenheiro civil, arquiteto, industrial e agrônomo , permitindo que se acumulasse mais de uma formação. Este não era o modelo adotado pela École Politechnique francêsa(fundada em 1795) que tem três anos básicos e prepara para as outras escolas Mines, Ponts et Chaussés. 0 modelo adotado é o de Karlsruhe onde estudou o fundador da Escola Politécnica ,Antonio Francisco de Paula Souza e também o de Berlim onde a arquitetura não é um curso especial como na École des Beaux Arts em Paris e na Escola de Belas Artes no Rio de Janeiro ,mas uma especialidade da engenharia.

As disciplinas mais voltadas ao setor de obras públicas estavam no curso de engenheiro civil nas cadeiras Estradas, pontes e viadutos ; Estradas de ferro; Navegação interior, canais , portos de mar e faróis ; Hidráulica ,Tecnologia Mecânica ; Resistência dos Materiais, Estabilidade das construções e Arquitetura civil .

As escolas e faculdades isoladas só serão reunidas em universidades a partir dos anos vinte do século passado. 0 modelo do Rio de Janeiro reunindo engenharia, medicina e direito é seguido em outros Estados .Em São Paulo,a primeira formação da universidade incluiu também a Faculdade de Filosofia Ciências e Letras.

A formação e consolidação do meio dos urbanistas ,em São Paulo ,nas primeiras décadas do século $\mathrm{XX}$, se faz através, também, da fundação de órgãos de representação de classe, instituições profissionais e a publicação de revistas especializadas. Estas atuavam como fóruns de divulgação e de debates das idéias e

11 O curso em Porto Alegre, por exemplo não incluía esta especialidade conforme Almeida, Maria de Soares "A Academia e o urbanismo no Rio Grande do Sul 1900-1972" in Leme ,Maria Cristina da Silva ( coordenadora) Urbanismo no Brasil 1895965 , São Paulo,Ed NOBEL , FAUUSP , FUPAM , 1999. 
realizações urbanisticas e sinalizavam as transformações do meio

O primeiro periódico a circular mensalmente foi a revista de Engenharia, em maio de 1879. Esta revista teve dois períodos até dezembro de 1884 e a segunda fase iniciada em junho de 1911 e que termina dois anos depois. Breve existência ,porém importante para os assuntos de urbanismo, principalmente na segunda fase. Por uma decisão editorial de publicar assuntos de interêsse público para incentivar a ampliação do campo de atuação profissional e conferir um sentido de contribuição social passam a analisar as obras de engenharia e assuntos referentes a problemas urbanos, como obras de saneamento, habitação, transporte urbano, questões relativas à eletricidade, tanto privada quanto pública e outros assuntos, a maior parte voltados às obras públicas indicando soluções ou novas tecnologias. A revista foi o principal meio de divulgação dos embates envolvendo os projetos para o Vale do Anhangabaú na primeira década do século.

Com linha editorial diferente vinculada à instituição surge, em 1900, o Anuário da Escola Politécnica de São Paulo que tratava de assuntos internos da escola e não passou do segundo número. Com a fundação do Grêmio Politécnico foi retomada a publicação e em novembro de 1904 começa a circular a revista. Os responsáveis pela publicação eram os próprios alunos. Ela divulga e desenvolve os temas das disciplinas em artigos escritos por alunos e por professores incluindo as questões de urbanismo ,como as conferências proferidas por Victor da Silva Freire ${ }^{12}$.

A terceira revista mais importante no período com artigos divulgando os temas relativos ao urbanismo e ao planejamento urbano é vinculada ao recém criado Instituto de Engenharia 13 O Boletim do Instituto de Engenharia como foi denominado foi criado em outubro de 1917. Ele para de circular com este nome, em 1935 ,mas tem continuidade, com o mesmo perfil editorial, na revista Engenharia.

12 A revista Mackenzie iniciada em 1915 pelos alunos da Escola de Engenharia do Mackenzie College, com o aval do grêmio da instituição. Dedicou-se a publicar artigos relativos à engenharia e arquitetura.O tema do urbanismo é secundário na publicação . 13 É fundada a Sociedade de Arquitetos e Engenheiros de São Paulo em fevereiro de 1912, mas não se tem noticia de atividade ; em maio de 1916 é fundado o Instituto de Engenhari 


\section{A engenharia Municipal}

Em $1892^{14}$, vigia o sistema de Intendências que não separava ainda as atividades do executivo e do legislativo. $\mathbf{O}$ fato novo que confere importância à Comissão Técnica de Melhoramentos da Cidade 15 é a proposta do diretor, engenheiro João Pereira Ferraz, em 1897 , de elaborar a Carta Geral da Cidade com o esboço do planejamento das obras públicas a serem executadas a médio e longo prazo . Vincula, pela primeira vez, a execução de obras de edificações, as retificações nos traçados viários ,enfim os melhoramentos e embelezamentos urbanos à organização de planos ou projetos urbanos. Segundo Grostein 16 , esta Comissão em conjunto com a Intendência de Gomes Cardim teria proposto uma grande avenida perimetral para São Paulo. Esta obra não se realiza., mas inaugura uma série de projetos de avenidas circulares em São Paulo. Este engenheiro havia trabalhado na Comissão de saneamento estadual e vai ser o primeiro responsável pela cadeira de Hidráulica urbana e saneamento da Escola Politécnica .

Apenas em 1898 é abolido o regime de Intendência e criado o cargo de Prefeito municipal. O primeiro a ocupar o cargo será Antonio Prado 17. A Intendência de Obras Municipais tinha como atribuições :o levantamento da planta cadastral do município, o mapa da cidade para a uniformidade dos alinhamentos e edificações, calçamentos e colocação de guias e aberturas de ruas. Todo e qualquer serviço devia ser dirigido e fiscalizado por engenheiro. Contava com um engenheiro chefe, um

14 Pela Lei no 1 Regimento Interno da Câmara Municipal de São Paulo,eram criadas quatro Intendencias : Justiça e Policia; Higiene e Saúde Pública, Obras e Finanças.

15 Idem Simões Jr, 1990,p 67

16. Grostein , Marta, "Os planos urbanísticos elaborados desde 1880 a 1980 , inclusive diagnóstiicos setorais globalizantes "INTRAURBE, São Paulo, 1983 p 15 , apud Campos Neto, opus cit ,p 81

17 Antonio Prado dominou o cenário político paulistano na primeira República. Proprietário de fazendas de café, banqueiro, acionista de companhia de estrada de ferro, de companhia de serviços de abastecimento de agua, foi o primeiro prefeito de São Paulo e permaneceu no cargo até 1910 . Neste período ele procura transformar a imagem colonial da cidade, redesenhando o traçado de praças e construindo um novo e imponente Teatro Municipal dominando as encostas do vale do Anhangabaú . 
engenheiro fiscal de viação, dois engenheiros de distrito, um escriturário, um desenhista e um alinhador. Em 189918 é criada a Seção de Obras na Intendência de caminhos , construções, ajardinamentos e arborizações .Esta seção contava com um diretor ,o engenheiro chefe, Victor da Silva Freire, um vice diretor, dois primeiros engenheiros, dois segundos engenheiros, dois auxiliares e um desenhista.

Em $1913^{19}$, na administração de Raimundo Duprat ,a seção é transformada em Diretoria de Obras e Viação com quatro seções. A $1^{a}$ seção- Escritório Central, Planta da Cidade, Edificações Particulares contava com dezesseis engenheiros. A 2a seção de Obras e Calçamentos Correntes, Viação Ordinária; a 3a seção cuidava da Conservação e a 4a seção de Expediente e Informações.

\section{Pioneiros do urbanismo no Brasil}

Observando a origem da formação e a trajetória profissional da primeira geração de engenheiros que atuou no decorrer do século XIX em São Paulo podemos observar algumas características em comum com os profissionais que atuaram nas principais cidades brasileiras. Eles são formados em escolas de Engenharia na Europa , caso da primeira geração de profissionais que atuou em São Paulo 20 ou formados na Escola Central no Rio de Janeiro, antiga Academia Militar, que em 1874 passa a ser denominada Escola Politécnica.

A corte atrae a maioria dos mais importantes profissionais da primeira geração que denominamos pioneiros do urbanismo no Brasil. Entre eles Francisco de Pereira Passos, Francisco de Paula Bicalho, Augusto da Silva Telles, Aarão Reis ,Theodoro Sampaio, André Augusto Paulo de Frontin, Francisco Saturnino de Brito ,Armando

18 Ato no $17 / 1 / 1899$

19 Ato $57316 / 4 / 1913$

20 Victor da Silva Freire era formado em Lisboa e Paris, Antonio Franscico de Paula Souza cursou a Escola Politecnica de Kalsruhe, na Alemanha e Francisco Ramos de Azevedo estudou em Gand, na Belgica. Samuel das Neve era formado em Salvador. 
Augusto de Godoi. 21

Participaram da criação e do corpo docente das Escolas de Engenharia em São Paulo, na Bahia no Rio de Janeiro. Estes profissionais atuaram e transitaram em diferentes especialidades da engenharia .É um campo profissional em expansão. Os conhecimentos de engenharia os habilitaram para a construção das estradas de ferro, de pontes e viadutos. A modernização das áreas portuárias incluiam a construção $\mathrm{e}$ reforço de diques, serviços de dragagem e aterros. Atuaram nas cidades na defínição do projeto de loteamentos, abertura e extensão de vias, elaboraram projetos urbanísticos para as áreas centrais das cidades.

O engenheiro paulista Antonio Francisco de Paula Souza, fundador da Escola Politécnica, filho e neto de políticos da região de Itu é um interessante exemplo. Seu percurso profissional se faz nas novas frentes de investimentos dos capitais paulistas acumulados na exportação do café. Sem dúvida as relações familiares e de negócios eram importantes elementos. Trabalhou na expansão da rede ferroviária paulista nas companhias Ituana, Paulista e Rio Clarense. Em Campinas realiza serviços de levantamento topográfico e dos recursos hidrícos para a formação de uma companhia de abastecimento de água 22 .

Pressionada pelas epidemias que assolavam as cidades a questão do saneamento passa a ser central para as administrações provinciais e os engenheiros são chamados para chefiar comissões no desenvolvimento de projetos e construção de redes de água e esgoto $^{23}$. Francisco Saturnino de Brito foi , sem dúvida, o urbanista que mais se destacou neste campo, no Brasil.

21 Ver a biografia destes engenheiros em Leme, Maria Cristina da Silva ( coord)opus cit.pp444-463

22Ver sobre este percurso Santos, Antonio da Costa Santos "Compra e venda de terra e água e um tombamento na primeira sesmaria da freguesia de Nossa Senhora da Conceição das Campinas do Mato Grosso de Jundiai 1732-1992"Tese de doutorado, FAUUSP, 1999 23 Destacam-se atuando no campo de saneamento neste período Lourenço Baeta Neves, Teodoro Sampaio e Francisco Saturnino de Brito.

24ver sobre o plano de Santos, Andrade , Carlos Roberto Monteiro de, "A peste e o plano.O urbanismo sanitarista do engenheiro Saturnino de Brito"dissertação de mestrado , FAU

USP,2vol, 1992. 
O plano de saneamento e extensão que ele realiza para a cidade de Santos de 1905 a 1910 é considerada a sua mais importante obra construida 24 .Nela, Brito inovou no emprego de técnicas para a solução de drenagem de aguas pluviais e no escoamento e tratamento de esgotos. Mas o aspecto principal de seu projeto, como destaca Andrade, é o plano de expansão da cidade. Ele não se limitava a resolver os problemas sanitários das partes construídas mas projetava também as áreas de expansão da cidade. Brito foi o exemplo mais significativo de uma prática, usual à época, de atuação profissional em diferentes cidades brasileiras. Ele fez projetos para um grande número de cidades brasileiras entre elas Recife no Pernambuco; Vitória no Espírito Santo e Porto Alegre no Rio Grande do Sul. Em São Paulo ele realiza, na década de vinte do século passado, um dos seus últimos trabalhos profissionais - $o$ projeto de retificação e urbanização da várzea do rio Tietê junto à Comissão de Melhoramentos do Tietê. A concepção biológica da cidade de Saturnino de Brito ultrapassa a imagem já banalizada no urbanismo sanitarista, de higienização de um organismo urbano doente que deve ser recuperado pela ação "médica" da engenharia urbana; para pensar, a partir da complexidade e complementariedade de partes especializadas de um organismo vivo, na articulação entre evoluções urbanas do futuro e elementos estruturais recuperáveis do passado. Esta concepção se manifesta na forma como divide a cidade em zonas utilizando como elementos definidores a topografia e os ventos dominantes. No seu projeto para a cidade de Santos são os canais de drenagem que definem a estrutura do sistema viário nas área de expansão da cidade.

\section{0 diretor de Obras Municipais, Victor da Silva Freire .}

Victor da Silva Freire foi a figura mais marcante da primeira geração de engenheiros urbanistas que atuou no ensino e na prefeitura de São Paulo. Português, formado pela Escola Politécnica de Lisboa completou seus estudos em Paris. Em 1895 , veio para São Paulo e trabalhou desde o início no setor de obras públicas. Quando Antonio Prado, em 1898, assumiu a prefeitura de São Paulo, nomeou Victor Freire chefe e, logo em seguida, diretor da Seç̧ão de Obras da Prefeitura, cargo em que permanece até 1926. Demonstra desde cedo competência profissional e capacidade de articulação 
de diferentes interesses politicos. O episódio da contratação de Antoine Bouvard é um exemplo, conforme descrevemos mais adiante. No final de 1897 passa a lecionar na Escola Politécnica onde permaneceu por 40 anos. Ministrou disciplinas vinculadas ao curso de engenheiro civil; engenheiro arquiteto e engenheiro industrial 25 Chegou a exercer a diretoria da Politécnica de 1932 a 1933.

Freire foi membro de algumas das mais importantes instituições do período : do Instituto de Engenharia de São Paulo, participou de conselhos de engenharia, do Clube de Engenheiros do Rio de Janeiro e da Associação dos Engenheiros Civis Portugueses. Também participou da "Société des Ingénieurs Civils de France" e da "Institution of Civil Engineers" de New York.

Acompanhava atentamente os trabalhos e as discussões que aconteciam nos congressos internacionais, trazendo para o cenário paulistano as idéias de urbanistas europeus e americanos. A formação européia e o constante contato com a produção urbanistica internacional marca sua atividade profissional e acadêmica .Participou dos principais congressos internacionais do período entre eles o organizado pelo RIBA Royal Institute British Architects, em 1911 na Exposição Internacional de Higiene da Habitação em Dresden. Participou também do primeiro Congresso Internacional e Exposição Comparada das Cidades realizado em Gand em 1913, quando foi eleito para o conselho diretor pela Union internationale des villes, indicação que ele, ironicamenete, atribue ao fato de ser o único representante brasileiro presente ao congresso 26 .

Nesse sentido, a transposição de modelos do ideário urbanistico europeu presente, por exemplo, na proposta, desenvolvida de um anel viário para a área central de São Paulo se faz de forma criteriosa, apontando com clareza as origens das idéias. De forma mais contundente critica a importação de parâmetros europeus presente na legislação

25 Com muito prestígio entre os alunos, ministrou as disciplinas 'Estabilidade das Construções' , 'Tecnologia do construtor mecanico', 'Mecanica Industrial' , 'Motores Hidraulicos,Fábricas'e tecnologia Civil e Mecanica - Materias de Construção' conforme .Simões Jr José Geraldo, 1991,opus cit , p 161

26; .Simões Jr José Geraldo “Anhangabaú : história e urbanismo”tese de doutoramento FAUUSP, 1995, p 162 
urbanística paulistana.

Analisando o seu percurso profissional destacamos três aspectos que articulam a sua formação, a atividade acadêmica e a longa permanência na Prefeitura .iniciamos pela sua concepção de remodelação da área central da cidade ; em seguida observamos a crítica aos padrões vigentes na legislação edilícia associada a uma capacidade de proposição de novos parâmetros atualizados aos conceitos de salubridade e, finalmente, a introdução de uma nova concepção de regulação dos serviços públicos.

Causa estranhamento hoje o fato de Freire sendo diretor da Seção de Obras da prefeitura participar ao mesmo tempo do Conselho da City of São Paulo

Improvements assessorando nas decisões sobre as áreas de investimento e compras de gleba da companhia. Entretanto, conforme observamos no estudo sobre o Plano de Avenidas 27 para entender a transformação da São Paulo colonial do século XIX à metrópole dos anos 50 é necessário observar a forma como se organizam os interesses das companhias estrangeiras de serviços públicos, em particular a Light and Power ,de negócios imobiliários como a Companhia City 28 , os grandes proprietários de glebas urbanas. sob a mediação da Diretoria de Obras da Prefeitura.

\section{A remodelação da área central da cidade}

O artigo, "Melhoramentos de São Paulo", conforme observamos anteriormente é um marco na história do urbanismo paulistano, em termos de reflexão sobre princípios urbanisticos. Neste artigo Victor da Silva Freire divulga os princípios do urbanismo moderno baseados no tripé: previsão, estética e salubridade.

Impressionado com as taxas de crescimento demográfico de Paris e Londres, ele destaca a necessidade de um plano para São Paulo. Aborda também a questão estética da forma urbana ao defender as posições do urbanista austríaco Camillo Sitte,

27 Leme, Maria Cristina da Silva "ReVisão do Plano de Avenidas: um estudo do planejamento em São Paulo, 1930"tese de doutoramento, FAUUSP, 1990 28 Carlos Roberto Monteiro de Andrade descreve a forma como se estruturam estes interesses em torno da Cia City em sua tese de doutoramento junto a FAUUSP “.Barry Parker, um arquiteto inglês na cidade de São Paulo, 1998 
trazendo o debate de duas posições antagônicas quanto ao projeto de desenho das cidades: a simetria dos traçados nascidos na prancheta e a irregularidade revalorizada do traçado histórico das cidades. A questão da salubridade urbana é introduzida através da discussão do papel dos espaços livres na saúde das populações. Propõe resguardar o vale do Anhangabaú como parque da cidade.

O objetivo principal do artigo é expor a sua proposta de reformulação do sistema viário na colina central. Para reforçar a sua argumentação, Victor Freire se apoia em duas concepções estéticas diferentes e até antagônicas:as idéias do urbanista austríaco Camillo Sitte e as de Mulford Robinson identificado por alguns autores com o movimento City Beautiful do urbanismo americano.

Camillo Sitte apresentou a crítica à racionalidade da intervenção do urbanismo moderno, opunha-se aos critérios únicos de eficiência e aproveitamento racional que passam a orientar o planejamento da cidade industrial. Propunha-se a recuperar, no projeto, os espaços que a configuração histórica proporciona à cidade.

Nos Estados Unidos uma nova fase do urbanismo se instaura, provocada pela realização da feira mundial de Chicago em 1893. Conforme observa Anhaia Mello "os enthusiatas da city beautiful nella se inspiraram e começaram a aparecer centros civicos imponentes, boulevards scenográphicos, fontes de marmore e os grupos de estatuária. É a primeira phase, a esthética."(Anhaia Mello, 1929, p 107). Ele considerava Mulford Robinson como filiado a esta fase do urbanismo americano. Para justificar esta classificação exemplifica com os títulos dos capitulos de um livro de Robinson escrito em 1901:1. Bases da belleza civica, 2.A belleza das ruas, 3. A phase esthética do esforço social, 4.A Phase esthética do esforço educativo, 5. Meios de garantir a belleza civica 29 .

O urbanista americano Nelson Lewis tem uma visão semelhante à de Anhaia Mello sobre o significado essencialmente estético deste movimento, no qual também situa

29 Anhaia Mello,Luiz Ignácio "A verdadeira finalidade do urbanismo"in Boletim do Instituto de Engenharia,no 51,1929,p 107 
Robinson e que denomina de City Planning Movement. 30

Discordamos em parte das considerações de Anhaia Mello e de Nelson Lewis quanto à percepção de uma preocupação estética dominante nas propostas de Mulford Robinson.Sem dúvida a preocupação do autor volta-se para os aspectos estéticos dos problemas urbanos .Mas essa preocupção tem como questão central resolver os problemas de circulação viária urbana.

Na proposta de Victor Freire de remodelação do sistema viário na área central de São Paulo, transparece uma síntese da sua percepção destas idéias - o aspecto estético , influência das idéias Camillo Sitte e o aspecto estético-funcional, influência dos princípios defendidos por Mulford Robinson.

A combinação harmoniosa entre o espaço construido e o espaço livre orienta o traço de Victor da Silva Freire na sua proposta de um anel viário na área central de São Paulo: a elegância do traçado curvilíneo das ruas, largas para permitir a fácil circulaçåo e dilatadas em pontos estratégicos de forma a configurar uma praça e abrigar um monumento; a valorização e o aproveitamento do sítio natural de Såo Paulo formado por vales e esplanadas.

Outro aspecto a destacar neste artigo de Freire é a associação de similariedade que estabelece entre o crescimento extraordinário das cidades européias e americanas no decorrer do século passado e o futuro crescimento de São Paulo. Ele afirma a necessidade de preparar São Paulo para o crescimento que ocorria em outras cidades em decorrência da industrialização. Aos princípios defendidos pelos higienistas de garantir a boa distribuição do ar e da luz ele acrescenta a necessidade da antecipação e da previsão. Esta constatação de similariedade entre processos urbanos e formas de atuação é uma das marcas do urbanismo que se pretende como um saber universal.

Freire propõe realizar as obras necessárias para a execução deste plano viário, de forma a onerar o menos possivel a municipalidade, cabendo à iniciativa privada a

30 Lewis, Nelson P. "The planning of the modern city .A review of the principles governing city planning"2nd ed., New York, John Wiley \& Sons, Inc ,1923, p 23 
realização da obra e à prefeitura apenas a indicação dos requisitos de projeto. No caso de obra realizada pela municipalidade, considera que dever-se-ía garantir que a valorização de terrenos, resultante das melhorias, não fosse apropriada individualmente, mas que retornasse aos cofres públicos.

A participação da iniciativa privada é vista com interesse e aprovada por Freire. Cita o exemplo da abertura de avenida realizada por particulares em Buenos Aires.Segundo ele,o mesmo processo havia sido solicitado, em São Paulo,"por abastados proprietários, taes como os srs.Conde de Prates, Plinio Prado,José Paulino Nogueira, Rodrigues Alves, Ramos de Azevedo, Arnaldo Vieira de Carvalho e Nicolau de Souza Queiroz.". Este processo apresentado por Alexandre de Albuquerque, descrevemos em seguida 31 .

Outra alternativa considerada promissora por Freire era a criação de corporações municipais, à semelhança do que se fazia na Alemanha. Naquele país, segundo o autor, ao se planejar a realização de uma operação urbana , guardava-se segredo sobre o empreendimento, até que a corporação tivesse adquirido, em boas condições, o terreno necessário. Desta forma a municipalidade tirava proveito da valorização decorrente da realização da obra.

A regulação das atividade na cidade: legislação urbanistica , contribuição de melhoria e concessão de serviços urbanos.

Na década de dez Freire publica artigos na Revista da Escola Politécnica e no Boletim do Instituto de Engenharia 32 sobre a questão da higiene e da salubridade. Ao abordar a influência que a luz e o ar assumem nas aglomerações humanas ele insiste na necessidade da multiplicação de espaços abertos. Victor Freire reforça o argumento

31 idem Freire,opus cit ,1911,p142

32 Os principais artigos que relacionam a questão da salubridade a novos padrões edilícios são:em 1914 "A Cidade salubre"pela Revista Politécnica; em 1916 "A planta de Belo Horizonte ( a propósito da cidade salubre)"também pela Revista Politécnica; em 1918 pelo Boletim do Instituto de Engenharia " Códigos Sanitários e Posturas Municipais sobre habitações. Um capitulo de urbanismo e economia nacional”. 
- ambientes físicos insalubres deterioram a saúde da população - apresentando dados estatísticos comparando a menor incidência de casos de tuberculose em Londres do que em Paris.

O inicío desta reflexão sobre a importância da insolação direta como fator de salubridade havia sido tema da introdução de Victor Freire á publicação da palestra de Alexandre Albuquerque pronunciada quando os dois engenheiros participam, em 1911, na Exposição Internacional de Higiene da Habitação, em Dresden 33.

Victor Freire foi o responsável pela elaboração de estudos de insolação e ventilação vinculando as normas para a construção da edificação ao desenvolvimento de padrões adaptados ao clima è̀s técnicas construtivas no Brasil. Ao tratar da posição da casa no lote, da disposição e tamanho dos comodos vai demonstrar a necessária exposição dos espaços de moradia à insolação e ventilação, mostrando que o que se espera do espaço arquitetônico é que ele cumpra a função climática de fornecer a melhor disposição do ar e da luz. Essas recomendações visavam a definição de uma regulamentação adequada 34 .

O diretor de Obras critica as "ideias feitas" referindo-se à adoção de regulamentações de outros países, sem visão crítica dos critérios que as definiram . Dá como exemplo a defínição da altura do pé direito obrigatório pelo Código Sanitário paulistano e que havia sido definido a partir das dimensões de volume mínimo de cômodos da legislação francêsa. $O$ código não levara em consideração as diferenças climáticas, como por exemplo a necessária ventilação em uma habitação em São Paulo ou ainda o padrão usual adotado nas dimensões dos cômodos, menores que os francêses. 0 urbanista criticava também a exigência de largura mínima de 16 metros para todas as

33 Albuquerque, Alexandre de "Higiene da residencia urbana" scp, São Paulo, 1917 conforme Campos Neto, 1999, p 204.

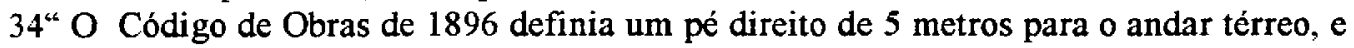
para os primeiros e segundo pavimentos de 4,50 e 4,20 metros respectivamente.Em $1894 \mathrm{o}$ primeiro Código Sanitário reduz as exigencias de pé direito para 4 metros .A lei Municipal de 1915 que regulamentou o segundo Código Sanitário do Estado de 1911 reduz novamente para 3,70"Somekh , Nadia "A cidade vertical e o urbanismo modernizador" São Paulo, EDUSP ,Ed Nobel , FAPESP , 1997 p 40. 
ruas da cidade.

A adoção sem crítica destes padrões estariam levando a um encarecimento desnecessário das construções. Como observa Somekh ${ }^{35}$, as propostas de Freire de redução do pé direito e de larguras de ruas diferenciadas propiciavam o adensamento e a utilização mais econômica do terreno pela redução do pé direito

Estas críticas se faziam no momento que a Câmara, por iniciativa do engenheiro arquiteto e vereador Heribaldo Siciliano, propunha, em 1917, um novo código de obras .Este projeto discutido pela Câmara é enviado ao Instituto de Engenharia para parecer. Fazem parte dos debates do projeto o próprio Heribaldo Siciliano, Victor Freire, Saturmino de Brito mostrando os vínculos do Instituto com o executivo, o legislativo e a importância como esfera de manifestação técnica 36 .

A contribuição mais importante de Freire para a elaboração do novo padrão municipal foi a limitação das alturas das edificações em relação à largura da via. Esta relação variava conforme a zona urbana permitindo as maiores alturas na área central e diminuindo até uma vez na zona suburbana. Ele propunha também fixar um número máximo de pavimentos por zona. As duas recomendações, encaminhadas pelo Instituto são discutidas, acatadas e modificadas pela Câmara. A relação altura da edificação / largura da via se mantém, mas é eliminada a restrição de altura o que representa uma possibilidade de verticalização grande, principalmente na área central.

Rolnik observa que a diferenciação de potencial construtivo introduzida por esta legislação possibiltava a verticalização e a valorização de terrenos da área central .Esta regulação diferenciada será estratégia recorrentemente utilizada para atualizar áreas altamente valorizadas na cidade 37 .

A cobrança de uma taxa pela valorização de terrenos pela realização de

35 Somekh, Nadia, 1997, opus cit.

36Para uma descrição detalhada do processo de elaboração do padrão municipal e do processo de discussão ver Campos Neto, opus cit, pp 205- 208

37 Rolnik, Raquel “A cidade e a lei”,São Paulo, Ed Studio Nobel , FAPESP, 1997, p 129 
melhoramentos é um tema introduzido por Freire 38 e que será mais tarde retomado por Prestes Maia , por Anhaia Mello e motivo de polêmica entre os dois engenheiros. A argumentação mais uma vez é construida expondo e discutindo o exemplo utilizado em outros países: a legislação inglêsa Town Planning and Housing Act, a legislação italiana e o dispositivo americano local assesment .Tratam -se de instrumentos de cobrança em que varia a proporção do que é taxado - sobre o valor integral no caso americano e italiano e sobre metade no caso da legislação inglesa.

No decorrer da década de dez, Victor da Silva Freire escreve sobre a regulamentação dos serviços urbanos ${ }^{39}$, em que reflete sobre as possibilidades de mudança nas relações contratuais entre o poder concedente e concessionárias de serviços públicos. Trata-se de um campo de atuação distinto ao de obras públicas analisado anteriormente e reflete o início de uma ampliação de áreas de intervenção da administração municipal.

Ele estava preocupado com os procedimentos a serem adotados pela Câmara Municipal para regulamentar novas formas de contrato com a Light, dado o término do contrato de concessão dos serviços de energia elétrica 40 .

A análise do autor é marcada pelas experiências americanas neste campo. Segundo Freire, a evolução da jurisprudência americana vinha se dando no sentido de admitir que a intervenção pública garantisse a função social dos serviços públicos. Ele destaca a formação de comissões especialmente criadas para analisar o funcionamento das empresas de serviços urbanos e sugere a adoção do mesmo sistema para São Paulo.

38 Freire, Victor da Silva 1911, opus cit p 13

$39^{\text {“O }}$ futuro das Concessões Municipais na cidade de São Paulo" Revista Politécnica nº 60 , $1919 ;$ p. $258-334$

40. Os setores de água, energia elétrica, gás, telefone, transporte coletivo foram objeto de concessão pelo poder provincial e municipal, inicialmente a empresários nacionais que os transferiram a empresas privadas de capital estrangeiro. Operando com uma lógica empresarial estas empresas detém o monopólio dos serviços urbanos do final do século XIX ao primeiro quartel do século $\mathrm{XX}$. 


\section{0s projetos para o vale do Anhangabaú .}

Os projetos propostos para o vale do Anhangabaú 41 a que se refere o artigo de Victor Freire revelam o processo de modernização da cidade, porém parcial e incompleto envolvendo apenas a sua porção central. A ação da municipalidade, neste primeiro período, tanto enquanto planos como em termos de intervenção pontual para o alargamentos de vias, abertura de praças não ultrapassava os limites dos bairros da Sé, Luz, Santa Ifigênia e Campos Elíseos.

Este projeto para a área central de São Paulo faz parte de um movimento mais geral de intervenção em áreas centrais nas principais cidades brasileiras. Ao valorizar novas áreas, próximas aos centros comerciais tradicionais, dão inicio ao processo de deslocamento das atividades centrais

Iniciado com o plano mais ambicioso do engenheiro Pereira Passos que envolveu a abertura da avenida central no Rio de Janeiro 42 , pode ser observado também no plano elaborado por Jeronymo Teixeira de Alencar Lima para parte alta da cidade de Salvador, na reforma urbana do bairro do Recife e no plano de Melhoramentos de J Maciel para a cidade de Porto Alegre 43 .

Talvez o mais limitado seja o elaborado para o vale do Anhanagabaú em São Paulo envolvendo apenas uma área da cidade e abordando principalmente os aspectos viários e a proposta de um conjunto de edificios .A existência de importantes interesses imobiliários consistiu na peça central da disputa entre projetos urbanísticos concorrentes. $\mathrm{O}$ estudo destes projetos revelou as estratégias utilizadas por grandes proprietários de terrenos na defesa de seus interesses. Revelou também a existência de

41Para fins deste trabalho, em que procuramos interpretar a importância destes projetos na formação do urbanismo paulistano nos limitamos a abordar os principais pontos que descrevem cada projeto Para uma descrição e análise detalhada destes projetos e dos interesses em jogo ver Simões Jr, José Geraldo, 1995, opus cit 42 Ver nos Planos de Conjunto para o Rio de Janeiro em Leme, Maria Cristina da Silva, opus cit $\mathrm{p} 358$.

43 Para uma descrição destes projetos ver Leme, Maria Cristina da Silva, opus cit p 280 a 297. 
conflito de esferas de atuação entre a Prefeitura, a Câmara e poder estadual.

O vale, em 1906, era ainda uma área abandonada com o córrego do Anhangabaú ao fundo, formada pelo fundos dos lotes das casas que davam suas frentes para as duas encostas, quando o vereador Augusto Carlos da Silva Telles 44 escreve e publica no ano seguinte um livro com o título "Os Melhoramentos de São Paulo"45. Observa-se o caráter propositivo do trabalho do vereador denotando permanências do periodo anterior em que a Câmara tinha também um papel executivo.

Silva Telles inicia o trabalho descrevendo o intenso crescimento de São Paulo e considerando indispensável que a Prefeitura ,através da diretoria de obras ,disciplinasse este crescimento e intervisse na área central. Esta é a parte mais substantiva do estudo, quando se refere às intervenções no setor central da cidade, abrangendo a colina histórica situada entre os vales do Anhangabaú e Tamanduateí.

A circulação viária apresentava-se como o maior desafio d ser enfrentado necessitando intervenções imediatas. Destacava como obras urgentes o alargamento de alguns cruzamentos onde a intensidade do tráfego era maior e a transformação da estreita e íngreme rua Libero Badaró, situada nos fundos da colina central e por isso abrigando inúmeros cortiços em uma larga avenida . "Dariamos ao centro da cidade um verdadeiro desafogo, dotariamos São Paulo de uma bella avenida central, dominando esse valle sob os dois viaductos, hoje tão mal aproveitado e que podera transformar-

44 Augusto Carlos da Silva Telles nasceu em São Paulo em 1851 e pertencia a uma tradicional familia paulista ligada à cafeicultura .Estudou Direito na Academia do Largo São Francisco, tendo depois se mudado para o Rio de Janeiro onde concluiu os estudos na Politecnica carioca, diplomando-se em 1878 como engenheiro civil e mecânico.Exerceu entre 1897 e 1898 o cargo de diretor de obras da Capital Federal Transferiu-se para São Paulo em 1898, como convidado para lecionar na Escola Politécnica, assumindo a cátedra do curso de Engenharia Industrial.Exerceu o cargo de vereador na Câmara Municipal paulistana entre os anos de 1905 a 1911 , período em que contribuiu de forma relevante para a cidade.

Desde 1906 , apresenta inúmeros projetos de lei procurando solucionar questões crônicas vividas pela cidade como a dos transportes coletivos, controle da expansão urbana .Dentro desse espírito que vai propor a transformação do vale do Anhangabaú.Esta proposta gera uma série de outras propostas por parte da Prefeitura e do governo do Estado.Apenas em 1911 será solucionada por uma proposta conciliadora do arquiteto francês Antoine Bouvard. Vide Simões Jr, 1995, opus cit

45 Silva Telles, Augusto Carlos "Melhoramentos de São Paulo", São Paulo, Escolas Salesianas Profissionais, 1907 
se em um sítio encantador $« 46$

Pouco tempo após a elaboração deste estudo, Silva Telles apresenta na Câmara Municipal uma nova versão para este projeto e que se torna o motivo para a série de projetos para o Vale que só terminaria com a proposta conciliadora do consultor francês Joseph Antoine Bouvard em 1912.

Neste projeto encaminhado à Camara, Silva Telles estende seu plano de intervenção para toda a área que compreende o Vale. Além do alargamento da rua Libero Badaró seria dado um tratamento paisagístico à região do fundo do vale onde poderia ter também uma outra avenida artísticamente traçada. Conforme observa Simões $F^{\circ}$ esta era uma idéia inovadora a de utilizar um fundo de vale para uma ligação viária , uma vez que a forma habitual de se abrir caminhos era pelos espigões ou pontos mais altos que não apresentassem problemas de drenagem 47 . Esta proposta dava início a uma prática que se difunde amplamente, em São Paulo,com o Plano de Avenidas, em 1930 ,de aproveitamento dos fundos de vale para a localização das principais avenidas .

Em 1907, logo após ter sido apresentado o projeto de Silva Telles , a diretoria de Obras resolve estudar melhor o assunto. 48 Dois processos simultâneos acontecem: por um lado o projeto na Câmara é alvo de ardorosos debates envolvendo membros das Comissões de Obras, de Justiça ,de Finanças e os representantes dos interesses dos proprietários de terras da região do Vale.Estes debates se estendem até 1910 quando é proposta uma solução conciliadora. Por outro lado o projeto de Telles estava sendo estudado e aprofundado pela diretoria de Obras, por seu diretor Victor da Silva Freire e pelo seu vice Eugênio Guilhem.

O eng. Guilhem justifica o plano como meio de desafogar a região central da cidade, alegando que o "triangulo central" detem quase toda a circulação urbana que vem aumentando, e não há possibilidades de alteração ou ampliação da área.

46 Telles, 1907p 41,42 Apud Simões Jr, 1995 opus cit

47 Simões Jr 1995, opus cit, p 77

48 "Projecto Freire Guilhem" Revista de Engenharia, 1o Volume, junho de 1911 maio de 1912 , p 41 
Projeto da diretoria de Obras. Fonte: Revista Engenharia ,1912.

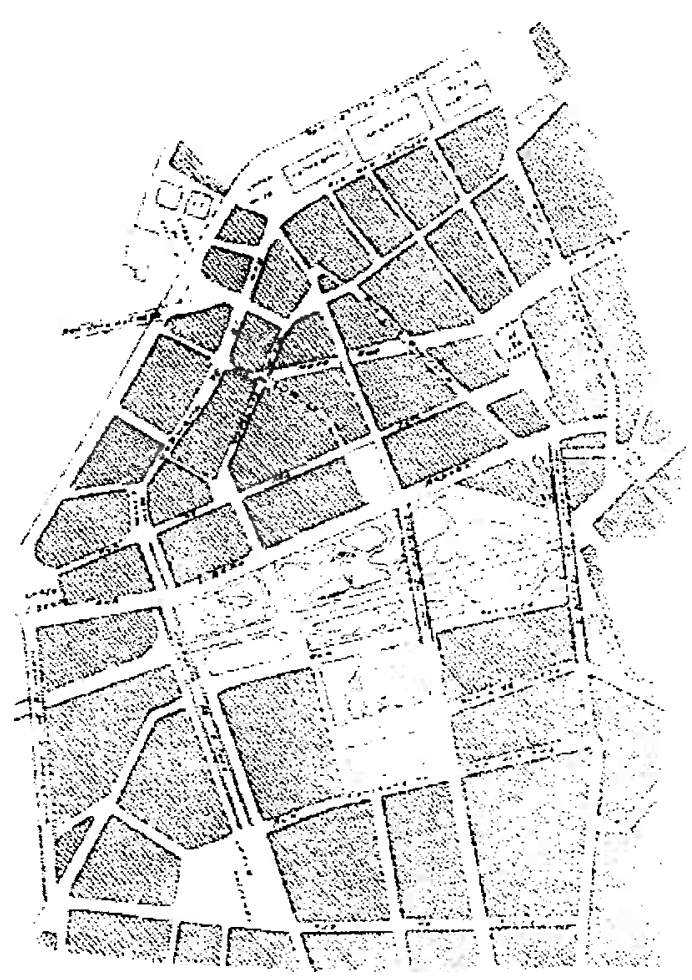

Ainda segundo o engenheiro, o governo vem tentando afastar o movimento do centro, através de obras como os viadutos Sta. Ifigênia e do Chá que ligam o centro a zonas mais planas para expansão. Porém, o viaduto Sta. Ifigênia não resolve o problema de trânsito no triângulo, apenas descongestiona o cruzamento das ruas São Bento e Direita, desviando o transito do viaduto do Chá. Eles propõem o alargamento e nivelamento da rua Líbero Badaró. Ela teria de 18 a $20 \mathrm{~m}$ de largura e só seria construída do lado par, do lado oposto rampas com pequeno declive gramadas e plantadas com vegetação dariam acesso ao parque .A rua se prolongaria em curva em direção à rua Santo Amaro e Brigadeiro Luíz António, cortando as encostas por onde descem as ladeiras do Ouvidor, São Francisco e Riachuelo.Propunham ainda outras obras a transformação da rua São João em larga avenida ,a criação de um largo em frente à igreja de Santo Antonio Para a execução de tal obra, a Prefeitura considerava essencial a aprovação de uma lei de desapropriação igual à utilizada no Rio de Janeiro em seus melhoramentos.

A prefeitura não tinha os recursos necessários para realizar as obras e cabe ao Estado 


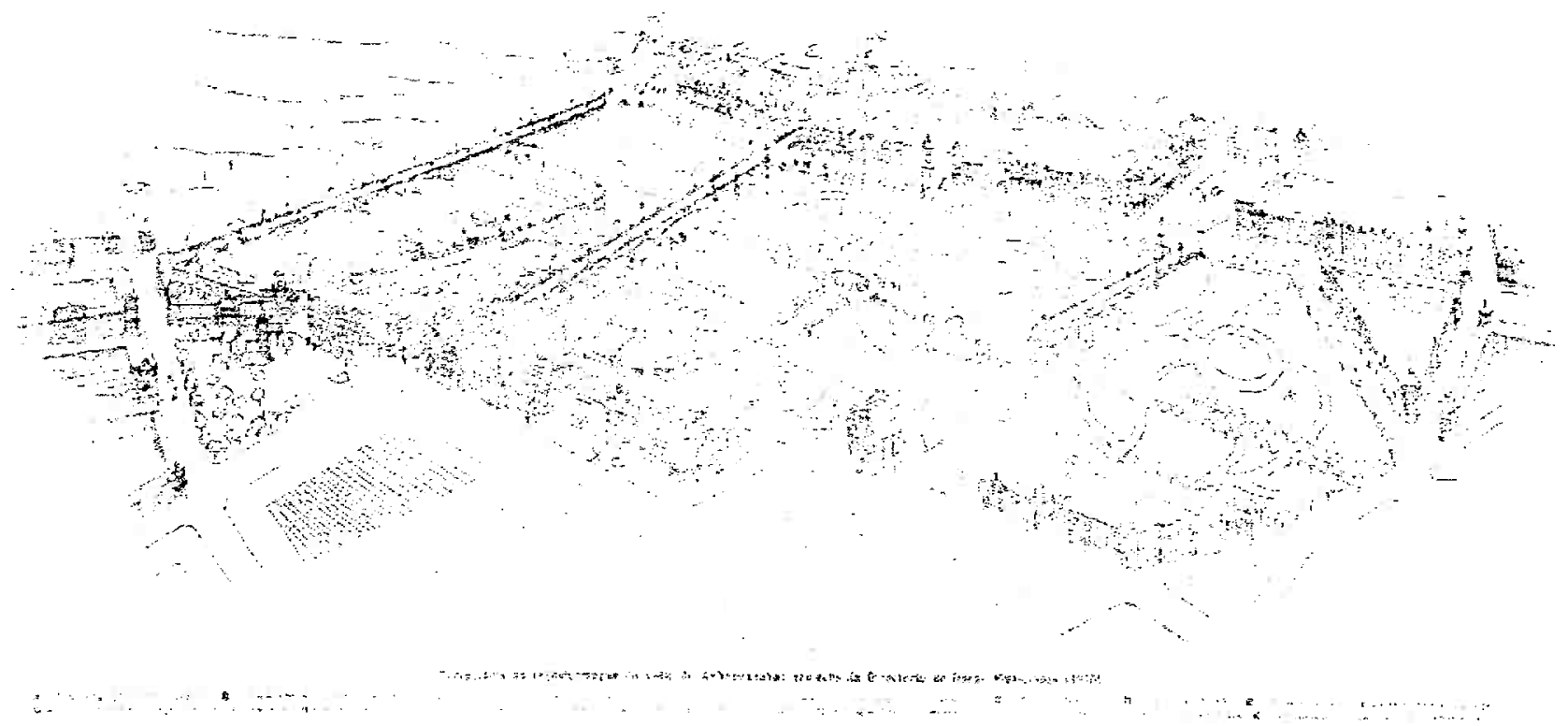
Perspectiva geral do projeto da Diretoria de Obras Municipais ( Freire - Guilhem) Fonte: Freire, Victor da Silva "Os Melhoramentos de São Paulo" Revista Politécnica no 33 São Paulo 1911

prever uma verba para a realização das obras. Mas não apenas concede a verba mas propõe um novo projeto para o Vale, de autoria de Samuel das Neves 49 . O engenheiro agrônomo baiano Samuel das Neves tinha um importante escritório técnico, que projetou e construiu centenas de prédios, desde residências simples ou de luxo, escolas, fábricas, escritórios, os primeiros prédios de apartamentos da cidade, hospitais e penitenciária.

O projeto é pouco elaborado Consistia no alargamento do lado impar da rua Libero Badaró e a construção de grandes edificios ao longo desta; construção de uma "avenida parque" de traçado retilíneo no vale do Anhangabaú (com $60 \mathrm{~m}$ de largura).Esta avenida, posteriormente, se prolongaria em direção a estação do Pari e da avenida Paulista passando pelos três viadutos.

Propunha ainda o prolongamento da rua Boa Vista, por meio de um viaduto de cimento armado, até ao palácio do Governo e a formação de uma praça em frente à igreja Santo Antonio (atual praça Patriarca). Criação de um viaduto do largo São Francisco ao largo da Memória, em substituição ao viaduto São João proposto pelo plano da Prefeitura, abertura

49 "Projecto Samuel das Neves" Revista de Engenharia, 1o Volume, junho de 1911 maio de 1912 .p 41. 
Projeto Samuel das Neves Plano das Grandes Avenidas. Fonte: Revista Engenharia, 1912

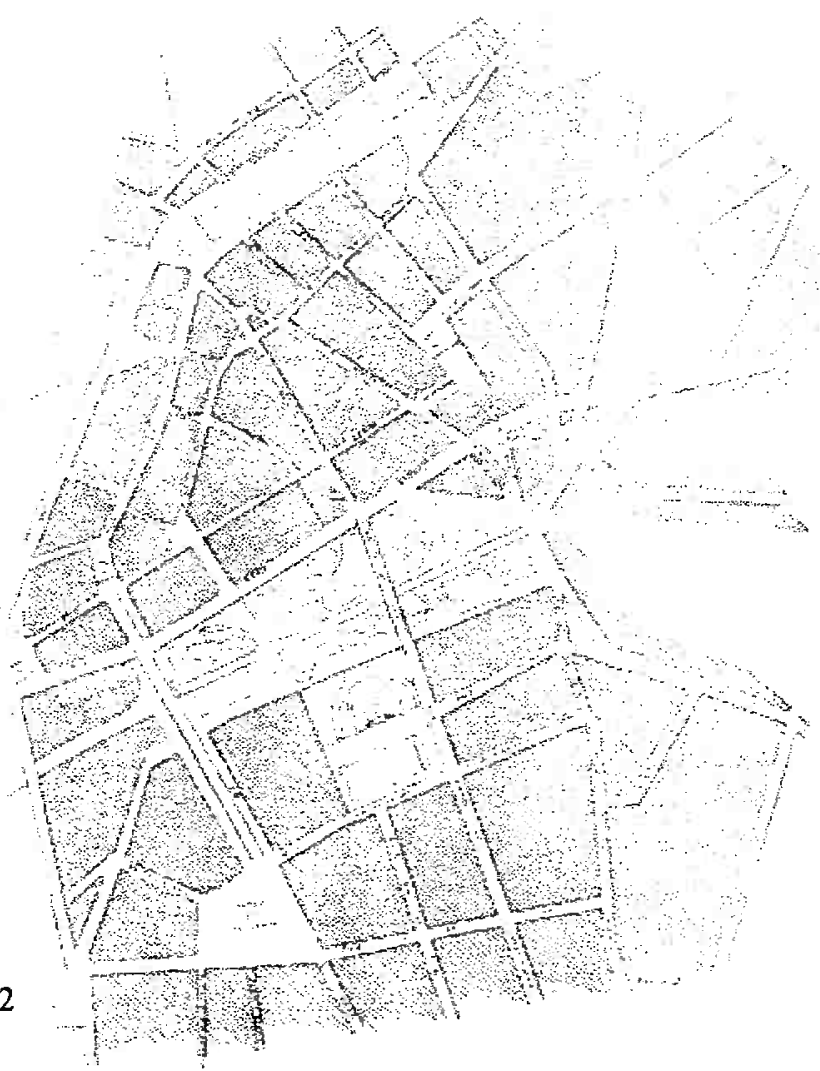

de uma nova rua (com $18 \mathrm{~m}$ de largura e com edificações do “...tipo da rua Rivoli, de Pariz...") partindo do cruzamento das ruas do Comércio e da Quitanda, como prolongamento da avenida Luiz Antonio.

A polêmica entre o projeto da Prefeitura e o do Governo do Estado foi ativada com a publicação do artigo de Victor da Silva Freire na Revista Politecnica. O Vereador Alcantara Machado influenciado pelas idéias de Freire propõe na Câmara Municipal a indicação de um árbitro para se estabelecer uma solução concilatória . Refere-se à possibilidade de convidar o arquiteto francês Bouvard que passaria pelo Rio de Janeiro a caminho de Buenos Aires onde estava elaborando um plano para a cidade.

Esta proposta é aprovada por unanimidade e Victor Freire parte para o Rio para convidar Bouvard. Logo depois o arquiteto francês está em São Paulo onde permanece por quarenta dias, contratado pela prefeitura 50 .

50 "O Relatório Bouvard" Revista de Engenharia, lo Volume, junho de 1911 maio de $1912, p 42$ 
O arquiteto francês Joseph Antoine Bouvard "diretor dos serviços de arquitetura dos passeios, de viação e do plano de Paris" 51 que passava por São Paulo,a caminho de Buenos Aires,em caráter oficial é contratado para elaborar um plano para a cidade.Este projeto para Buenos Aires ele o apresenta, em 1913, no Congresso de Gand. O projeto para o vale do Anhangabaú em São Paulo, ele o faz, aparentemente, através de seu escritório, em carater particular.

A vinda para o Brasil, em 1911 , foi um convite do banqueiro francês Edouard Fontaine de Laveleye 52 e é solicitado pela prefeitura de São Paulo a opinar sobre dois projetos que estavam em discussão para o Vale do Anhangabaú: o de Samuel das Neves pela Secretaria da Agricultura e o da Diretoria de Obras elaborado por Victor Freire e Eugenio Guilhem. Ele propõe uma terceira solução conciliadora .Segundo a revista La Construction Moderne ele envia ainda um conjunto de planos elaborados "após uma vasta pesquisa sobre os recursos presentes na cidade, as condições de circulação e a orientação para o seu crescimento 53 " sugerindo abertura de vias, criação de parques, a valorização de alguns edificios e a urbanização de alguns bairros.

Com a idade de 71 anos, à véspera da aposentadoria Bouvard participa de empreendimentos imobiliários, mas desta vez não mais em caráter oficial e sim como serviço pessoal. Ele torna-se vice presidente da City of São Paulo, Improvements and

510 arquiteto francês Antoine Bouvard, nascido em 1840 , foi aluno de Constant Dufeux e trabalhou com Adolpho Alphand, responsável pelos projetos dos grandes parques realizados na remodelação de Paris .Participou das exposições universais de Paris de 1870,1889 e 1900 .Realizou o plano de avenidas e parques da cidade de Buenos Aires entre 1907 e 1910 e seu nome havia sido citado varias vezes por Victor Freire no artigo. Simões Jr ,opus cit, $p$ 171.

52 Recebeu uma proposta de um amigo francês radicado no Brasil Edouard Fontaine de Lavelaye. Contatado por vereadores de São Paulo,Alcantara Machado e Cincinato Braga para que ao passar com destino a Buenos Aires fizesse estudos para área central de São Paulo.Bouvard passa dois meses na cidade apresenta relatório para a Prefeitura em 15 de maio de 1911.Fontaine de Lavelaye pede a Victor Freire que o apresente a diversos proprietários para que constituisse uma empresa imobiliaria .Logo em seguida associa-se a Cincinato Braga e Horacio Belfort Sabino e banqueiros londrinos e constitue Cia City comprando 1200 ha na cidade."Simões Jr , opus cit ,p 171 . .

53La Construction Moderne 27 mai 1905, p 420 apud Chatelet, Anne Marie "Joseph Antoine Bouvard"mimeo. 
Freehold Land Company Limited onde fará os primeiros empreendimentos concebidos segundo o modelo das cidades jardim inglesas .

Anne Marie Chatelet observa que a partir da "observação destes dez anos de missão a serviço da cidade de Paris, pode se perceber alguns traços constantes, em particular sua forma de preferir a adição de pequenas intervenções pontuais a um plano de conjunto. Estas intervenções são a via em diagonal, a criação de espaços verdes, o destaque aos monumentos, formulas do breviário hausmmaniano que na realidade nunca foi escrito. Neste sentido Bouvard aparece como um legatário de Alphand, um homem que exporta até São Paulo e Buenos Aires o que não havia sido teorizado mas que todos admiravam ao visitar Paris , a obra de Haussmann"

Saliente-se, entretanto, o caráter parcial da transposição do modelo francês. As transformações de Paris no período da administração do Barão de Haussmann não se limitaram a abertura das grandes avenidas em percée que tiveram um efeito devastador no tecido urbano da cidade incluiram, principalmente, obras de infraestrutura de água e esgoto para toda a cidade.

Apegando -se ao aspecto formal do projeto para o vale baseado no modelo bastante difundido através das exposições universais em que a cidade de Paris passa a ser um dos elementos na vitrine, os políticos e técnicos paulistanos aprovam o projeto que conferia uma nova imagem àcidade.

Bouvard havia sido o encarregado da direção dos serviços de arquitetura nas exposições universais. Estas exposições constituem momentos importantes de difusão não apenas dos produtos comerciais francêses como também representaram a oportunidade de difusão das realizações no campo do urbanismo .A cidade de Paris passa a participar de forma independente nas exposições e Bouvard ,como funcionário da prefeitura ,foi o responsável pela construção do Pavillon da cidade de Paris em 1878 e pelo Palais des Expositions Diverses na Exposição internacional em Paris em 1889. Supomos que nesta ocasião tenha feito os primeiros contatos com Antonio Prado, senador do império, nomeado pela princesa regente Isabel como responsável pela execução do programa de despesas da Comissão franco brasileira na exposição universal de 1889 . 
Os desenhos apresentados por Bouvard são marcados por um traçado orgânico dos arruamentos .As plantas, segundo Simões Jr, são apresentadas em duas versões. Sómente na segunda, mais detalhada, apresentada em uma escala que permite a leitura e compreensão imediata aparece a versão conciliadora que permite a implantação de dois grandes corpos de edifícações no lado impar da rua Libero Badaró.O projeto de Bouvard se completa com um plano global de arruamentos para as áreas de expansão do centro e por um projeto de transformação da várzea do Tamanduateí onde seriam construídos o novo Mercado Municipal e um pavilhão para exposições agrícolas e industriais 54 .

A Revista de Engenharia traz o relatório entregue ao prefeito por Bouvard.O artigo descreve a composição do estudo: com planta geral da cidade e indicações das propostas; plantas das alterações no centro da cidade; projeto de prolongamento da rua D.José de Barros; planta das alterações entre as ruas Líbero Badaró , Formosa e variantes; projeto de um parque na várzea do Carmo e variante.

O arquiteto considera sua proposta um "programa de ação" a ser desenvolvido pela municipalidade, onde leva-se em consideração a situação atual numa análise do processo de crescimento da cidade.

Considera necessário alterar-se o modo de se traçar o sistema viário ("xadrês absoluto"), levando-se em consideração a situação topográfica. Considera ainda, inútil grandes alterações no "triãngulo" central para seu descongestionamento. É necessário desviar o trãnsito dessa região para vias que envolvam a região.

Outros pontos tratados são a criação de parques e áreas verdes e um centro cívico formado pelos edificios da catedral, congresso, palácio do governo, paço municipal, palácio da justiça.

A transformação do vale será feita na administração Washington Luis .Porém não é apenas este projeto de Bouvard que será realizado, outro mais interessante pela

54 Simões Jr , 1995,opus cit, p 127 
localização será implantado no mesmo período. Descrevemos o projeto de Bouvard para a Várzea do Carmo e o de Alexandre Albuquerque de grandes avenidas com o objetivo de lançar algumas luzes sobre as formas como eram concebidas as relações entre o poder público e os interesses econômicos no início do século, em São Paulo.

\section{Projetos de parceria publico privado: as Grandes Avenidas e a Varzea do}

\section{Carmo.}

No artigo de Freire ele faz referência também ao projeto apresentado "por abastados proprietários, taes como os srs.Conde de Prates, Plinio Prado,José Paulino Nogueira, Rodrigues Alves, Ramos de Azevedo, Amaldo Vieira de Carvalho e Nicolau de Souza Queiroz.".Este projeto, apesar de não realizado, é um interessante objeto de estudo por revelar a proposta de uma nova relação entre os investidores imobiliários e a

Plano das Grandes Avenidas.

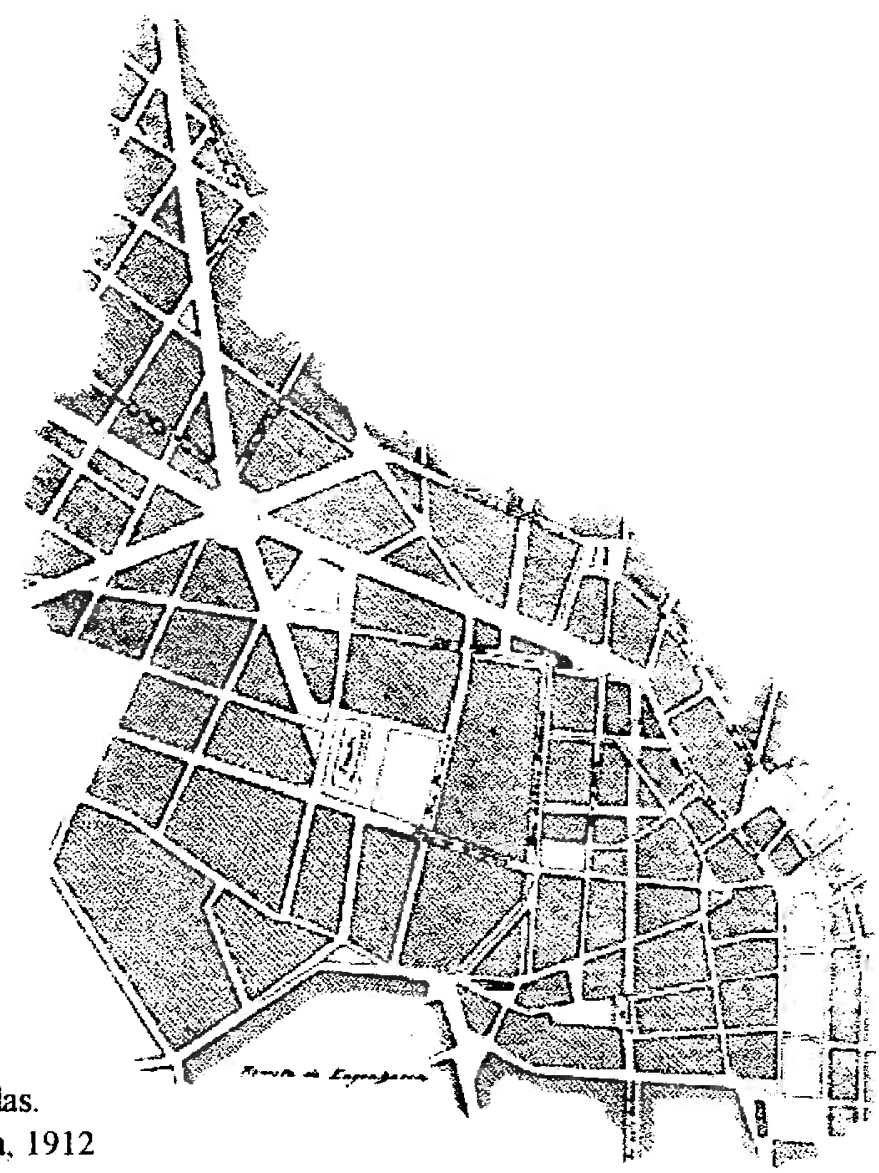


prefeitura, representando um momento de passagem na relação publico privado na produção da cidade.

Este momento pode ser observado quando se comparam as formas como eram realizados os melhoramentos na área central, por particulares como no caso do projeto e construção do Viaduto do Chá , por Jules Martin ,no início do século; pelo poder público( Prefeitura, Govemo do Estado e Câmara) nos projetos para o Anhangabaú

Por ocasião da entrega do projeto do arquiteto Bouvard à Câmara Municipal, o arquiteto Alexandre de Albuquerque fala de antecedentes a este, principalmente sobre o projeto das "Grandes Avenidas" 55 que, segundo o autor, não "desperdiçou as idéias já concebidas pela prefeitura, tentando desta maneira disciplinar o tráfego na região central e o tráfego das estações ferroviárias até o centro".

Para Albuquerque o plano de Bouvard e o plano das Grandes Avenidas partem de premissas diferentes, sendo que o plano de Bouvard encerra uma série de sugestões que possam ser executadas dentro do orçamento previsto pela Prefeitura. Já o plano das Grandes Avenidas encara com seriedade os planos antecedentes e considera a participação da iniciativa privada, sem gerar grandes custos a Prefeitura.

Considera ainda que, para traçar um plano de melhoramentos, não seria necessário a Prefeitura buscar técnicos estrangeiros, não prestigiando os técnicos nacionais.

O projeto foi enviado em petição ao Congresso Legislativo do Estado, em 14 de novembro de 1910. solicitando licença para a intervenção na cidade. Os requerentes da petição são: Conde de Prates; Plínio da Silva Prado; José Paulino Nogueira; José Martiniano Rodrigues Alves; Francisco de Paula Ramos de Azevedo; Arnaldo Vieira de Carvalho; Nicolau de Sousa Queiróz; Barão de Bocaina; Alexandre de Albuquerque; Horácio Belfort Sabino e Sylvio de Campos.

55 "O Projecto Alexandre Albuquerque" Revista de Engenharia , lo Volume , junho de 1911 maio de 1912 , p 37,38;"As grandes Avenidas e os Melhoramentos " Revista de Engenharia ,10 Volume, junho de 1911 maio de 1912 , p 44, 45 
O plano previa três grandes avenidas na região central da cidade. A primeira partindo da Praça António Prado, atravessando o vale do Anhangabaú, extendendo-se entre as ruas de São João (atual av. São João) e Visconde do Rio Branco (atual av. Rio Branco), indo sempre em linha reta, e posteriormente atingindo a região do Bom Retiro e Freguesia do Ó.

A segunda avenida partindo do Teatro Municipal, seguindo em linha reta, passando entre as estações ferroviárias Inglesas e Sorocabana, posteriormente prolongando-se convenientemente e a terceira saindo o do largo Sta. Ifigênia, seguindo em linha reta até o largo do Arouche, dai seguindo pela rua Jaguaribe em direção a Higienópolis e Perdizes. A interseção dessas três avenidas formaria uma grande praça.

O plano previa detalhes de embelezamento, tais como: na praça formada pela intersecção das avenidas, se instalaria um monumento à cidade; a travessia do vale do Anhangabaú seria feita por arcadas, com edifícações de sobrado, desde o solo, nas suas laterais; o calçamento seria "... a madeira ou asfalto..." ; todas as edificações ao longo das avenidas seríam de dois ou mais pavimentos, obedecendo "... aos modernos estilos arquitetónicos...".

Além disto, seriam reservados espaços para: parque, jardim botânico e zoológico, na extremidade de uma das avenidas; paço do Congresso Estadual; palácio do Governo; nova Catedral; Correios e telégrafos; e outra para edificação de interesse municipal. Edificios comerciais seriam construídos pelos próprios requerentes. Também aos requerentes, caberiam arcar os custos do empreendimento, utilizando-se de capitais nacionais e estrangeiros. Porém, os requerentes solicitavam do poder público o seguinte:

- direito de desapropriação de uma faixa de $80 \mathrm{~m}$ de largura de cada lado das avenidas, com direito a revenda e alienação;

- concessão exclusiva de linhas de "ömnibus-automóveis" servindo as avenidas e suas ligações;

- implantação de rede de água e esgoto e iluminação por parte do govemo;

- financiamento de $1 / 4$ do orçamento previsto ("160.000:000\$000"), com obrigação de restituição por parte dos requerentes com juros de $5 \%$ por 10 anos; 
- intervenção do governo Estadual junto ao governo Federal para importação de materiais destinados à obra.

O autor ponderava ainda que o plano não intervinha na área de interesse histórico e elevado valor o que dificultava intervenções nesta área; facilitava a ligação da parte antiga com os novos bairros e com a estação da Luz.

Observava também que a perspectiva do centro da praça projetada “... só será comparável àquela que se aprecia em Paris, no cimo do arco da praça da Estrela..."Facilitava a comunicação entre as estações das estradas de ferro, o centro, e os bairros da Liberdade e Vila Mariana; a ligação dos Campos Elíseos, várzeas do Tieté, Higienópolis, Sta. Cecília, Perdizes e Lapa com a praça Antonio Prado.

Como observa Freire em seu artigo, este projeto não foi aprovado pelo Congresso Estadual.Porém,em áreas menos valorizadas da cidade o problema era tratado de forma diferente. O prefeito de São Paulo,em 1914,Washington Luis Pereira de Souza sugeriu que o construtor do aterro da várzea do Carmo e da canalização do rio Tamanduateí, obras de grande dimensão, recebesse o pagamento do seu trabalho, não em dinheiro, mas em terrenos da várzea, que depois de recuperada, teria grande valorização.

A várzea do Carmo foi objeto de propostas, recusas e aprovações da Câmara de São Paulo,desde 1890.Nesta época, segundo observa Lemos ${ }^{56}$, Augusto Cezar de Miranda Azevedo e Samuel Malfatti requereram a concessão de terrenos públicos na várzea, que seria numa faixa de $240 \mathrm{~m}$ saneada, aterrada e os terrenos loteados e vendidos. O pedido foi aprovado pela Câmara e depois recusado por intervenção de Prudente de Moraes, governador do Estado seguindo a argumentação de vereadores que alegavam a inalienabilidade de terrenos públicos. Em 1918, a várzea foi saneada e urbanizada segundo planos de Bouvard, pela companhia da Várzea do Carmo, presidida pelo Visconde de Moraes. A companhia recebeu em troca terrenos para lotear e vender.

56 Lemos , Carlos"A alvenaria burguêsa" São Paulo, Nobel , 1985, p 59 


\section{Os projetos de retificação e canalização para o rio Tietê. 57}

A formação de Comissões precede as estruturas administrativas mais formalizadas na intervenção das cidades .Um exemplo é a constituição da Comissão de saneamento que teve importante atuação nas obras de abastecimento de água e redes de esgotos nas cidades de Santos e Campinas .Em São Paulo são no âmbito desta Comissão elaborados os projetos de retificação do Tamandauteí

Os planos e projetos elaborados para o Tamanduatei e depois para o rio Tietê revelam o desenvolvimento de um saber técnico que combinava as obras para a regularização do curso do rio, de canalização, o aproveitamento como canal navegável ao projeto de urbanização das margens para atividades de recreação, de circulação e de lazer .Também neste campo aparece a dupla inserção profissional nos quadros da administração pública estadual e municipal e no ensino da cadeira de Hidráulica da Escola Politécnica 58 .

Os primeiros planos de retificação do Tietê são de fins do século XIX, motivados pelo agravamento das condições de saneamento de suas várzeas, bem como pela situação crítica provocada por suas enchentes periódicas. Em 1887, estudos feitos quatro anos antes pelo Barão de Guarajá propondo a retificação conjunta dos rios Tietê e Tamanduatei são refeitos sob orientação do Eng Bianchi Bertoldi. Resulta o primeiro projeto de retificação do Tietê, o do Visconde de Parnaíba, então presidente da Província.

Em 1894 , sob a chefia do eng João Pereira Ferraz da Comissão de Saneamento do Estado de São Paulo, criada em 1892 são reelaborados os projetos anteriores. Começam a ser sistematizadas observações e medições do rio. A ameaça das

57para uma descrição mais detalhada destes projetos ver Andrade, Carlos Roberto Monteiro e Leme, Maria Cristina da Silva "O rio Tiete : dos meandros às avenidas marginais"in II Seminário Metrópoles Latino Americanas, São Paulo, Anais, UNCRD, FAUUSP, FUPAM, 1993, vl.

58 São docentes na cadeira de Hidráulica João Pereira Ferraz , João Florence de Ulhôa Cintra, Lysandro Pereira. 
epidemias levou ao início das obras de retificação do rio que resultou em um aumento da declividade e portanto da velocidade de escoamento das aguas.

Em 1913, o engenheiro Pacheco e Silva apresenta ao governo do estado proposta mais ampla incluindo além da retificação do rio, parques laterais e à margem esquerda a localização de uma linha de bonde. Propunha a construção de uma eclusa e construção de um cais para navegação junto a foz do Tamanduateí. Este projeto representa uma transição de projetos de retificação dos fins do século XIX e as elaboradas nos anos vinte que contemplavam o aproveitamento e o tratamento da várzea.

Apenas em 1922 o engenheiro Fonseca Rodrigues, professor da Escola Politecnica ,retoma a pedido da Diretoria de Obras Municipais os projetos para o rio, chegando a uma nova proposta. O projeto consistia de dois diques laterais de terra e impermeáveis, paralelos ao ao canal com 108 metros de largura e $4.5 \mathrm{~m}$ de altura sobre cujo topo correriam duas avenidas de $20 \mathrm{~m}$ de largura cada. O canal era dividido em dois leitos : o maior constituído pelos diques laterais destinado ao escoamento das enchentes , o menor via navegável quando o maior estivesse seco. Destaca-se neste projeto um açude móvel para regularização da vazão do rio ,situado na altura da Ponte Grande,criando um lago artificial de $3 \mathrm{~km}$ de extensão por quase $1 \mathrm{~km}$ de largura. Este lago juntamente com um segundo lago proposto deveria ser aproveitado para a prática de esportes náuticos.

No entanto o projeto de Fonseca Rodrigues será criticado pelo diretor de Obras do Município Victor da Silva Freire "por delinear a solução Hidráulica a traços largos"descurando os aspectos de aformoseamento da cidade. É apresentado em substituição o projeto do eng João Florence de Ulhôa Cintra. O novo projeto mantem uma certa sinuosidade do rio tanto por critérios estéticos pinturescos, como por motivos de economia ,pois o traçado em linha reta atravessaria áreas urbanizadas - Vila Guilherme e Vila Maria , mas também por motivos técnicos , já que o uso de dragas recomendava a proximidade entre o novo canal e o curso natural do rio. Ulhôa Cintra propõe o rebaixamento da altura dos diques do esboço de Fonseca Rodrigues e aumenta a largura do leito maior do canal, encaixando-o dentro da ampla avenida parque (park - way) 
Em 1924 Francisco Saturnino de Brito é encarregado pela Câmara Municipal e pelo prefeito de São Paulo, Firmiano Pinto de dirigir os trabalhos da recém criada Comissão de Melhoramentos do Rio Tietê. O programa da Comissão deveria dar conta dos seguintes aspectos: defesa contra inundações da várzea no trecho junto à cidade, navegação ao longo deste trecho e afastamento para juzante das descargas de esgotos que se faziam sem depuração. Tratava-se, portanto , de um projeto amplo em que o aproveitamento da várzea para expansão urbana se destacava como objetivo principal.Saturnino concebe um projeto de aproveitamento do rio e ocupação da várzea. Ele reduz a extensão do leito entre a penha e Osasco de 46,3 km para $26 \mathrm{~km}$, aumenta a seção de vazão e aterra as áreas mais baixas da várzea possibilitando a recuperação de uma área de $25 \mathrm{~km}^{2}$ então inundável, a formação de dois lagos que

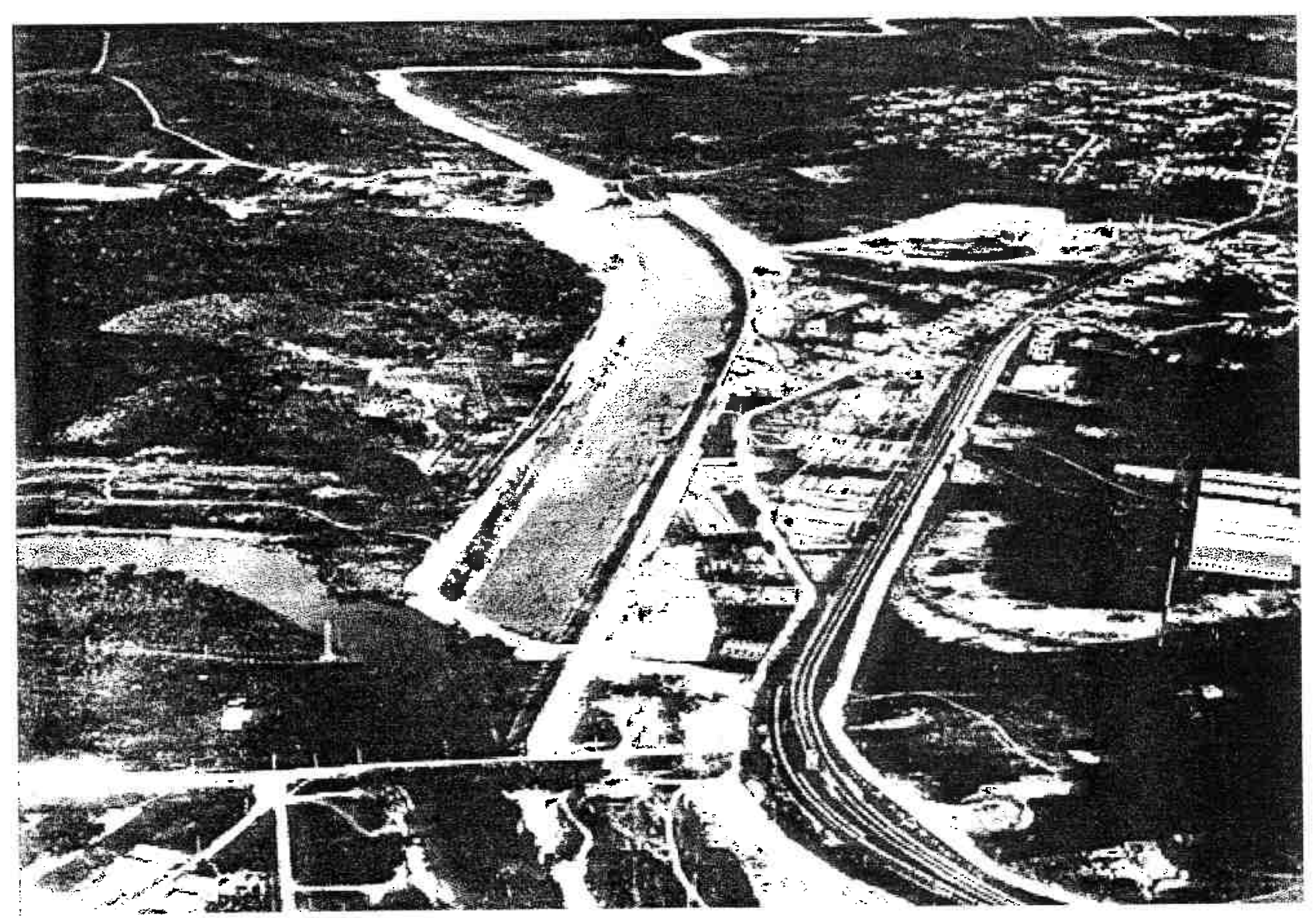

Abertura canal Tietê, trecho Osasco.Fonte Maia, Francisco Prestes Os Melhoramentos de São Paulo ,2a edição, Prefeitura Municipal de São Paulo, 1945 
forneceriam terra para este aterro e contribuiriam para melhorar as condições de vida urbana pela possibilidade de prática de esportes náuticos. Brito organiza para o rio Tietê dois projetos referentes a dois tipos de seção cada uma delas com três variantes aplicadas a trechos distintos da retificação.

Uma das características do projeto de Brito é a preservação da várzea como reservatório natural de regularização do rio.

As avenidas marginais ao rio já aparecem no projeto de Ulhôa Cintra, em 1923, mas assumem uma configuração definitiva , integradas a uma proposta total para o sistema viário da cidade, sete anos depois, no Plano de Avenidas elaborado pelo engenheiro Francisco Prestes Maia.

Na gestão de Prestes Maia, na Prefeitura, são iniciadas as obras de canalização do trecho Osasco a Ponte Grande. Abandona-se o traçado pinturesco proposto nos projetos anteriores , a possibilidade de navegação do rio, os lagos e as avenidas marginais acompanham o traçado do canal. A prioridade é a questão da drenagem e de entregar à urbanização vastas áreas inundáveis ou antes ocupadas pelos meandros do rio.

No próximo capítulo observaremos a nova forma de planejar e intervir na cidade resultado de um processo de amadurecimento de um conhecimento técnico que se gestou neste primeiro periodo. 


\section{CAPÍtULO II}

\section{A CONSOLIDAÇÃO do MEIO do URBANISMO.}

Nas três primeiras décadas deste século ,observa-se a formação entre os urbanistas paulistas de um determinado saber sobre a cidade , forma de conhecimento articulada a uma forma de intervenção (planejada)da administração municipal.

Procuramos mostrar que a visão de cidade ,como objeto de intervenção, inicialmente restrita à área central amplia-se gradativamente. São elaborados os planos de conjunto , principalmente planos viários para a totalidade da área urbanizada. Acompanha este movimento uma percepção de uma necessidade de atuação crescente do Estado ,que deve assumir a responsabilidade pela execução de obras e a regulação e regulamentação das atividades de produção imobiliária e de serviços urbanos.

O urbanismo e o planejamento urbano estão desde o início umbilicalmente ligados ao Estado .A defesa de um campo de trabalho profissional para o engenheiro na administração municipal nos parece uma evidência de que a continuidade do planejamento urbano é garantida, em parte pela própria burocracia ,ligada a esta atividade, preocupada em preservar as funções e posições alcançadas.

As idéias de urbanistas franceses, alemães e americanos são utilizadas de forma seletiva , parcial. O traço que une esta somatória de citações, muitas vezes contraditórias, é a utilidade que tinham de fundamentar, conferir legitimidade, à argumentação das propostas. A partir do momento em que urbanistas estrangeiros suo contratados como consultores e passam a disputar o mesmo espaço de atuação profissional pode-se observar que seus pareceres são objeto de ressalvas e de críticas por parte dos urbanistas paulistas.

A partir dos anos trinta pode-se observar a consolidação do urbanismo paulista tanto como área de conhecimento como campo de atuação profissional. 


\section{A palavra urbanismo}

Victor da Silva Freire introduz o termo urbanismo no vocabulário técnico paulistano ao citar o neologismo francês urbanismel e já o emprega, em 1918, no título do artigo "Códigos sanitários e posturas municipais sobre habitação (alturas e espaços )Um capítulo do urbanismo e de economia nacional", publicado pelo Boletim do Instituto de Engenharia .

A partir dos anos 20 , a palavra urbanismo se torna de uso corrente .Não designa apenas uma pratica como melhoramento mas pretende conceituar uma área de conhecimento. É utilizada referindo-se, inicialmente, às questões da administração e, em seguida, ao planejamento da cidade.

Sem dúvida ,o urbanista que empenha o maior esforço para a constituição deste campo de conhecimento e de atuação profíssional foi o engenheiro Luiz Ignácio de Anhaia Mello. Sua atividade profissional articulava o ensino, a política (vereador e prefeito) e a militância acadêmica .Ë o responsável pela introdução do ensino de urbanismo na Escola Politécnica. Publica no Boletim do Instituto de Engenharia, de 1927 a 1933 , uma série de artigos em que difunde de forma extremamente didática as experiências, principalmente norte-americanas, no campo da regulação e regulamentação urbana. Aborda nos artigos temas como a defesa da legislação urbanística, incluindo o zoneamento, formas de financiamento de obras através da cobrança de taxas de melhoria e a criação de novas instâncias de participação da comunidade no planejamento da cidade. São os temas que darão o conteúdo do ensino de urbanismo na engenharia e que constituirão a sua agenda política nos dois breves mandatos frente a Prefeitura de São Paulo. O primeiro artigo desta série sobre o governo e a administração das cidades "Urbanismo" fora o tema de conferência proferida no Rotary Club ,instituição de grande prestígio na época

Em 1929 é criada uma Divisão de Urbanismo no Instituto de Engenharia como um

\footnotetext{
1 Em artigo de 1916 "A planta de Belo Horizonte "publicado pela Revista Politécnica no 52 ele se refere à tradução do geômetra francês Julian Julian no livro Introdução ao Urbanismo "Town planning em inglês, stadtbau em alemão e urbanisme em francês"
} 
fórum específico de divulgação dos debates na área. A seção de Urbanismo na Diretoria de Obras na década de vinte é o indício de uma crescente importância do planejamento urbano na estrutura administrativa da Prefeitura.

Como um campo em formação e sem autonomia a própria definição das palavras mobiliza os urbanistas. Em principio concordam com a definição do arquiteto e sociólogo francês Donat Alfred Agache que urbanismo é ao mesmo tempo ciência e arte - unindo a formação na engenharia e na arquitetura. "Urbanismo é a arte científica do arranjo e da disposição das aglomerações humanas" 2 ; o urbanista "a la fois un scientifique et un artiste, un raisoneur et un intuitif'"3.

Porém esta dupla formação, unindo a engenharia e a arquitetura ,dez anos mais tarde já é questionada refletindo a questão social que passara a penetrar no meio urbanístico a partir dos anos 30 . O engenheiro Henrique Lefevre associa a cidade ao organismo doente. "Urbanismo na acepção moderna do vocábulo é sciencia e arte de apropriação e de extensão das cidades (...)não basta ser apenas engenheiro ou architecto. Ele muito deve ter de sociólogo(..) Pondo ordem no plano das cidades : preparando a sua extensão removendo males sociais physicos e moraes que melhor se originaram pela defeituosidade de seu desenvolvimento material ; cuidando não só do plano , porque tem de encarar o organismo que na cidade vive (...). É pelo urbanismo que mais se evidencia a função social do engenheiro". 4

Apesar da criação em 1948 da Faculdade de Arquitetura separando-se da engenharia e incorporando o urbanismo como disciplina, dois artigos 5 mostram na década de 50 a permanência da associação do urbanismo à engenharia. $O$ de Anhaia Mello denomina-

2 Anhaia Mello, Luiz Ignácio "Problemas de Urbanismo : mais uma contribuição para o calçamento" Revista Politécnica , no 83, 1927, p344

3 Anhaia Mello, Luiz Ignácio'Um grande urbanista francês : Donat Alfred Agache" Revista Politécnica, no85, 861928 , p 70

4 "O Urbanismo e a ação social do engenheiro" Revista Mackenzie, no 68 , 1938 p 179182

5 Anhaia Mello ,Luiz Ignácio "Engenharia e urbanismo - profissão e personalidade" Revista de Engenharia Mackenzie, no 124, 125,1955 p 2-5 Prestes Maia , Francisco "Arquitetura e arte" Revista de Engenharia Mackenzie , no 126, 1955 p 67-70 
se Engenharia e urbanismo - profissão e personalidade .No número seguinte publicase Arquitetura e arte por Francisco Prestes Maia .Se o primeiro amplia e inclui diferentes disciplinas no campo do urbanismo, inclusive a arquitetura, no segundo o tema são as artes plásticas .No início o autor distingue "três campos complementares importantes para a formação do profíssional perfeito : o científico, o político e o artístico, entendidos cada qual em sentido lato. Ao engenheiro químico, eletricista ou calculista importa o primeiro; ao industrial e ao urbanista o segundo campo ; ao arquiteto importa sobretudo o terceiro, pelas íntimas relações com a matéria de sua atividade" 6 .

\section{A disciplina urbanismo}

Urbanismo fazia parte do curriculum do curso de engenheiro civil mas, principalmente, do curso de engenheiro arquiteto. A cadeira de Hidráulica Urbana e Saneamento tinha como subtítulo Noções de Urbanismo (em suas relações com a técnica sanitária).Na década de vinte do século passado ,ministrada por João Florence de Ulhôa Cintra tinha o conteúdo voltado para as questões sanitárias :a relação edificação/lote, traçado das ruas, drenagem e disposição de detritos, mas também com alguns princípios de urbanismo : zoneamento e cidades- jardim 7 .

Porém é no curso de engenheiro arquiteto, por iniciativa de Luiz Ignácio de Anhaia Mello, que será ministrada a disciplina com conteúdo específico de urbanismo. Desde 1922 ele era o titular da Cadeira de Estética e seus primeiros artigos abordam as questões da estética das edificações. A partir de 1927 ele introduz a questão do urbanismo e a Cadeira passa a ser chamada Estética, Composição Geral e Urbanismo dirigida aos alunos do $5^{\circ}$ ano 8 .

Abordava os conceitos de urbanismo e urbanização, detalhava as legislações urbanísticas recentes nos países europeus e nos EUA, os transportes e a sua

6 Maia , Francisco Prestes ,1955, opus cit , p 67

7 ver programa da disciplina in Birkholz, Lauro "O ensino do planejamento territorial no Brasil", São Paulo, 1967.pp 192,193

8 ver programa da disciplina in Birkholz , Lauro, 1967 ,opus cit pp 198-201 
regulamentação, os serviços públicos, o zoneamento, o modelo cidade jardim de Ebenezer Howard, dos planos regionais, o de Nova York e a experiência americana de plano. nacional.

É importante apontar a coerência e consistência da forma de atuação de Anhaia Mello. No conteúdo desta disciplina estão presentes os temas que ele irá desenvolver em artigos, conferências e na sua atuação política: defesa da regulação e regulamentação das atividades de produção do espaço urbano; a definição do campo do urbanismo e planejamento urbano na estrutura administrativa da prefeitura de São Paulo e a filiação à vertente de urbanismo que defende uma organização territorial a partir de uma forma de organização social.

A dupla inserção do urbanismo na arquitetura e na engenharia não acontecia apenas em São Paulo mas era uma característica da formação em outras cidades brasileiras como Belo Horizonte e Porto Alegre. No Rio de Janeiro, Marques observa ${ }^{9}$ uma rivalidade entre a Escola Politécnica e a Escola Nacional de Belas Artes pela formação em arquitetura , atribuindo - a à disputa pelo mercado de trabalho em expansão devido às reformas urbanas no início do século. Ela argumenta que os trabalhos de reforma urbana passam a ter como componente importante a transformação estética dos conjuntos urbanos, sendo a formação artística atributo da arquitetura ,os engenheiros passam a se apropriar da formação em composição arquitetônica também .

\section{A segunda geração de engenheiros urbanistas paulistas e a consolidação do} meio.

Nos anos vinte uma nova geração de urbanistas atua nas cidades brasileiras 10 Formados nos cursos de engenheiro civil e engenheiro arquiteto são os responsáveis

\footnotetext{
${ }^{9}$ Marques, Sonia, opus cit, p 27

10Para uma leitura da biografia da segunda geração de engenheiros que atuou nas cidades brasileiras ver Leme, Maria Cristina da Silva, 1999, opus cit , pp465-509.Entre eles encontram-se alem dos engenheiros citados, os urbanistas paulistas Chistiano Stockler das Neves, Carlos Roberto Gomes Cardim
} 
pela consolidação do urbanismo como campo de conhecimento e campo de atuação profissional . Participam da organização de setores de urbanismo nas associações de classe. Organizam congressos de Habitação e de Urbanismo e compõem o corpo docente das escolas de engenharia e da Escola Nacional de Belas Artes, no Rio de Janeiro, onde introduzem a nova disciplina de urbanismo. Nos quadros técnicos da Prefeitura e do Governo do Estado são os responsáveis pela concepção dos primeiros planos para a totalidade da área urbana na época.

Em São Paulo, as revistas Politécnica e Boletim do Instituto de Engenharia continuam a ser as principais publicações para a divulgação do tema de urbanismo. A partir de 1929 este tema ocupa cada vez um espaço maior nestas publicações devido à intensa produção escrita de Anhaia Mello .

Circula a partir de 1939 uma curiosidade, a revista Paulistâniall. Dedicada aos soldados da Revolução de 1932. ecoando os ideais revolucionários paulistas se propôs a promover uma identidade paulistana. Destacam-se artigos que registram através de fotografias as transformações do espaço físico da cidade.

As questões de urbanismo começam a interessar um público especializado mais amplo no final da década de 40 .A revista Digesto Econômico, editada pela Associação Comercial de São Paulo, desde 1944, propunha-se cobrir um espaço editorial de divulgação econômica, ao alcance do publico leigo. Publica não apenas temas de conjuntura como as críticas de Prestes Maia ao Programa de Melhoramentos elaborado pelo IBEC, mas assuntos mais gerais como sobre o modelo cidade jardim por Anhaia Mello.Com o tempo sua linha editorial foi ficando mais clara, assumindo uma postura liberal.

11 A Revista Paulistânia começou a ser publicada em 1939 e foi até 1979 , ficando interrompida de outubro de 1944 até julho de 1947 Era publicada pelo Departamento de Cultura do Clube Piratininga que havia sido fundado a 16 de dezembro de 1934.

t, pl75. 
O evento mais importante 12 deste período é o 1o Congresso Brasileiro de Urbanismo , organizado pelo Departamento de Urbanismo do Centro Carioca de 20 a 27 de janeiro de 1941 .Foi o primeiro evento nacional cobrindo as questões profissionais do urbanismo naquele momento. Realizado no mesmo formato dos congressos internacionais tinha a seguinte organização visitas, conferencias, sessões plenárias onde eram apresentados e discutidos temas, teses apresentadas e aprovadas em plenário. Os temas abordados nas teses apresentadas ao Congresso foram: habitação, problemas de saneamento, serviços de utilidade pública, congestionamento, proteção dos monumentos históricos e artísticos, regulamentação dos loteamentos, planos reguladores e regionais.

As visitas deste congresso foram ao aeroporto, ao "Rio antigo" e ao "Rio moderno", às construções do IAPI, às favelas e à Ilha do Governador. Teve almoço no Rotary Club e exposição de urbanismo com a apresentação do plano do escritório Coimbra Bueno para a cidade de Goiânia.

Participaram deste congresso os principais nomes do urbanismo, do Rio de Janeiro Carmem Portinho, Francisco Batista de Oliveira, Sampaio Corrêa, Attilio Correa Lima, Nestor de Figueiredo, Morales de Los Rios, José Mariano Filho, Luis Dodsworth Martins, José de Oliveira Reis, Abelardo e Jeronimo Coimbra Bueno; de São Paulo Saturnino de Brito Fo, Luiz de Anhaia Mello Carlos Gomes Cardim Filho; de Belo Horizonte, Lincoln Continentino e do Recife José Estelita .

As sedes locais do Rotary Club , como pode ser observado neste congresso, foram locais importantes para a exposição de idéias e debates. Neste período,em cidades como o Rio de Janeiro e São Paulo, serviram como fórum de divulgação das idéias

12 Precede este congresso, tambem importante, porém de âmbito mais local, a Semana de Urbanismo organizado pela Comissão do Plano da Cidade de Salvador Nas conclusões do encontro dois pontos se destacam como rupturas ao ideário e praticas vigentes em Salvador : a defesa da necessidade de um plano para regular o crescimento e submeter decisões parciais à visão de conjunto e a defesa do urbanismo enquanto um novo campo de conhecimento e de atuação profissional.Vide Fernandes, Ana; Gomes, Marco Aurelio F; Sampaio, Antonio Heliodorio, "A constituição do urbanismo moderno na Bahia 1900-1950"in Leme, Maria Cristina da Silva, opus cit, p175. 
urbanísticas. $\mathbf{O}$ engenheiro Anhaia Mello, antes da existência de um setor especializado em urbanismo no Instituto de Engenharia, profere a primeira palestra sobre urbanismo no Rotary de São Paulo.

O objetivo inicial do Rotary era a criação de uma rede de relações sociais e principalmente de negócios 13 . Talvez a forma de organização do Rotary em que é necessária a indicação de um membro para o ingresso como rotariano confira legitimidade como fórum de divulgação. Estabelecia-se também como uma rede de relações internacional, conforme observamos na correspondência do IBEC sobre o prefeito de São Paulo Armando de Arruda Pereira .

Em 1934 a iniciativa de fundar uma Sociedade Amigos da Cidade tem o apoio tanto de Anhaia Mello como de Prestes Maia , que será o primeiro presidente. Esta sociedade, que existe até hoje no centro da cidade de São Paulo, pretendia um papel de intermediação entre a iniciativa privada e a administração municipal, reproduzindo teses levantadas por Anhaia Mello, como a necessidade de criação de uma comissão do plano da cidade.

\section{João Florence de Ulhôa Cintra e o perímetro de irradiação}

Na segunda geração de urbanistas paulistas, destacam-se João Florence de Ulhôa Cintra, Francisco Prestes Maia e Luiz Ignácio Romeiro de Anhaia Mello, com percursos profissionais bastante diferentes 14 . Imprimem uma nova concepção de intervenção urbanística na cidade e princípios de administração municipal. A passagem para este segundo período do urbanismo paulistano se faz sem rupturas com o passado, apropriam-se parcialmente de idéias, modificando-as, acrescentando outras idéias, sem explicitar as diferenças.

13 Fundado em 1905 em Chicago por Paul Percy Harris tinha por objetivo inicial reunir um grupo de colegas de negócios em um ambiente informal.O nome rotary foi sugerido porque designaria o esquema rotativo dos encontros. in Rotary Club de Santos edição comemorativa do $70^{\circ}$ aniversário, $\mathrm{s} / \mathrm{d}, \mathrm{p} 3$

14 para uma biografia completa destes engenheiros ver Ficher, Sylvia, opus cit . 
João Florence d'Ulhôa Cintra formou-se engenheiro civil em 1911 pela Escola Politécnica de São Paulo. Trabalhou durante toda a vida no serviço público, entrando para a Prefeitura de São Paulo, ainda estudante.

Na Secretaria de Obras foi nomeado, em 1925 , chefe da Divisão de Urbanismo, da Seção de Cadastro e Urbanismo ${ }^{15}$ que tinha como atribuições : a organização do cadastro, o estudo de um plano geral de viação, remodelação, embelezamento, melhoramentos, extensão, e sistematização para regular o desenvolvimento e a vida da cidade, a fixação e fiscalização dos alinhamentos e nivelamentos e todas as questões relativas ao urbanismo.

Ulhôa Cintra começa a lecionar na Escola Politécnica na cadeira 'Hidráulica das cidades' como assistente de João Pereira Ferraz .Assume como titular em 1927 a cadeira 'Hidráulica, Hidráulica Urbana e Saneamento das Cidades' tendo por

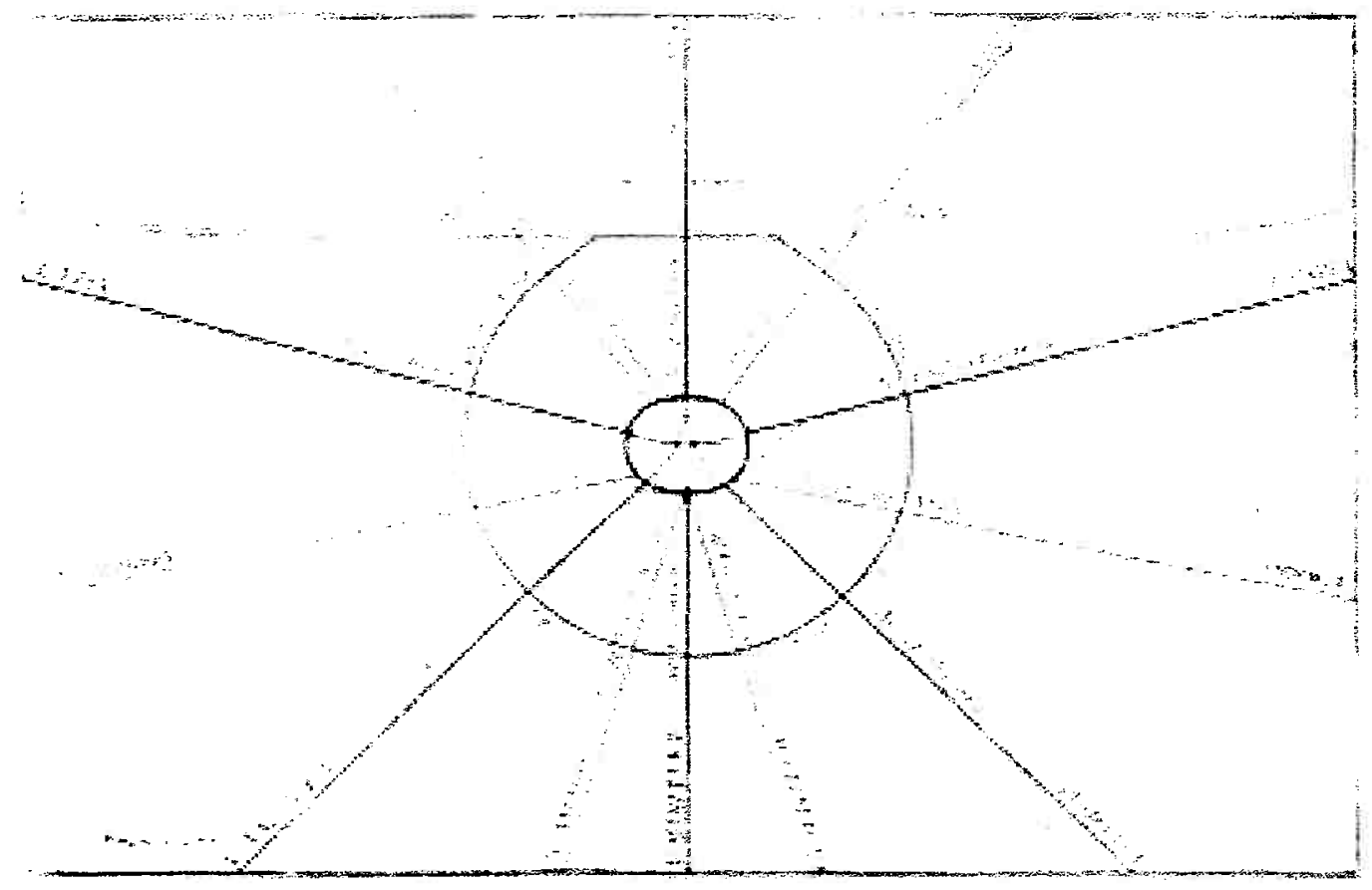

Esquema teórico de São Paulo, segundo João Florence de Ulhôa Cintra. Fonte: Maia, Francisco Prestes Estudo de um Plano de Avenidas para São Paulo São Paulo, Melhoramentos,

15 a seção é criada pela lei 2898 10/8/1925 
assistente Lysandro Pereira da Silva. Amplia , como observamos anteriormente o conteúdo da disciplina incluindo os estudos de hidráulica no campo do urbanismo. Esta dupla inserção no serviço publico e no ensino não apenas conferia prestígio mas garantia também notoriedade além dos limites do Estado. $O$ convite para prestar consultorias em outras cidades é um dos sinais deste reconhecimento. Este é o caso quando é convidado, em 1943 a elaborar um plano para a cidade de Recife.

O artigo "Projeto de uma avenida circular constituindo perímetro de irradiação" publicado no número 24 do Boletim do Instituto de Engenharia ${ }^{16}$, representa o ponto de partida do conjunto de propostas de reformulação do sistema viário que vão ser desenvolvidas de forma cada vez mais elaborada por Ulhôa Cintra em conjunto com Prestes Maia .

A preocupação central do autor é mais abrangente do que a proposta que desenvolve. Partindo da premissa que São Paulo, uma cidade com um "futuro brilhante e crescimento rápido" pretende "enfrentar o problema da urbanização da cidade segundo programa amplo, seguro, planeado conforme regras consagradas pela experiência e estudos alheios" 17 .

Estas são as considerações preliminares para o autor desenvolver uma solução viária para a cidade. $O$ exemplo adotado por Ulhôa Cintra é o das cidades européias onde o crescimento urbano se fez a partir das direções "naturais" de desenvolvimento : do núcleo central saem as vias radiais .Esta solução se contrapõe ao traçado em xadrez adotado nas cidades americanas.

Segundo Ulhôa Cintra o traçado viário de São Paulo lembra o das cidades européias "com núcleo central e vias radiais de bom traçado". Para melhora-lo e resolver a circulação do centro da cidade adota o esquema desenvolvido por Eugène Hénard .Na

16 este estudo elaborado como funcionário municipal é apresentado à Câmara em 1922. Annaes da Câmara Municipal de São Paulo, Typographia Piratininga, São Paulo, 1922, p 573 apud Campos Neto, opus cit, p 247

17 Cintra,João Florence de Ulhôa "“"Projeto de uma avenida circular constituindo perímetro de irradiação" no 24 Boletim do Instituto de Engenharia ,1924,p 331 
comparação do traçado viário de três cidades européias : Berlim, Londres e Moscou o urbanista francês percebe um elemento em comum "uma espécie de circuito fechado ou collector, que nos propomos chamar perimetro de irradiação e que , traçado a uma certa distancia do centro mathematico da cidade. Este perímetro representa um grande papel no plano das três capitaes; por assim dizer, o regulador da circulação convergente, que attingiria a inextrincavel chaos, si todas as vias concorressem ... mesma praça. É elle que recebe as correntes affluentes e que as distribue em seguida, com o auxilio das pequenas ruas secundarias até o edificio ou a casa que é o escopo do movimento individual de cada elemento da circulação"18.

Ele desenvolve, a partir do esquema de Hénard, um projeto de uma via circular constituindo perimetro de irradiação para São Paulo.

\section{A colaboração de Ulhôa Cintra e Prestes Maia - esboça-se o plano para São Paulo.}

A discussão sobre o planejamento urbano e mais precisamente a elaboração de um plano para a cidade é introduzida gradualmente na estrutura administrativa da Prefeitura através de duas instâncias uma proposta pela Câmara e outra pelo executivo e que teriam funções semelhantes e concorrentes. Por iniciativa do legislativo ${ }^{19}$ é proposta a criação de duas comissões : uma técnica composta por técnicos da Prefeitura para elaboração do Plano Geral de Conjunto e uma consultiva composta por professores das Faculdades de Engenharia, Medicina e Direito e representantes do Instituto de Engenharia, $\mathrm{OAB}$, comerciantes e industriais para acompanhar os trabalhos desta.

A partir de 1924 ,se estabelece uma colaboração entre Ulhôa Cintra e o jovem engenheiro Francisco Prestes Maia , funcionário de Departamento de Obras Públicas

\footnotetext{
18 idem, Cintra, 1924, opus cit ,p 332

19 ler sobre o papel desempenhado pelo vereador Orlando Prado na defesa da criação de um curso de urbanismo para a formação de tecnicos nacionais capacitados assim como a formação das comissões para elaboração de um plano de conjunto para a cidade. in Campos Neto opus cit p 259
} 
do Estado e professor da Escola Politécnica .Desenvolvem uma série de estudos, publicados pelo Boletim do Instituto de Engenharia que contem as principais idéias desenvolvidas quatro anos depois por Prestes Maia na elaboração do Plano de Avenidas 20 .

Nestes artigos exaltam a imagem de liderança de São Paulo no processo de desenvolvimento do pais. A garantia para a continuidade deste processo, afirmam

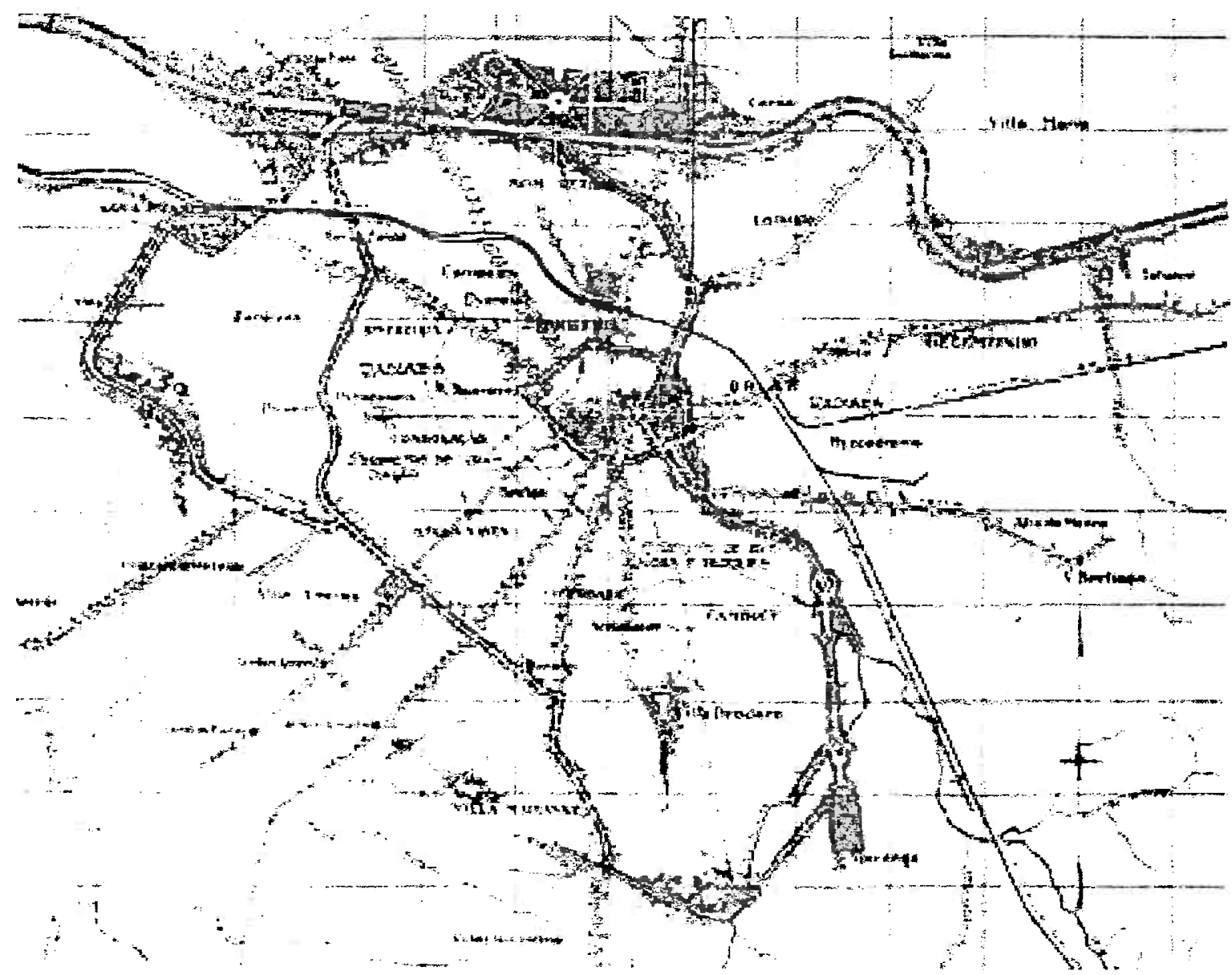

Esquema do Perímetro de Irradiação, Radiais e Circuito de Avenidas e Parques. Francisco Prestes Maia e João Florence de Ulhôa Cintra. Fonte: boletim do Instituto de Engenharia.

20 "Um problema actual :Os grandes melhoramentos de São Paulo",realizado por Prestes Maia e Ulhôa Cintra junto à Comissão Técnica do Plano da Cidade, da Diretoria de Obras e Viação da Prefeitura de São Paulo.O trabalho foi apresentado à Câmara Municipal e publicado no Boletim do Instituto de Engenharia de outubro de 1924 a junho de 1926. 
Prestes Maia e Ulhôa Cintra, dependia da remodelação da cidade. No segundo artigo publicado começam a insistir na idéia do plano. A idéia é nova : plano integral, plano de conjunto as denominações variam mas a intenção é a mesma : antecipar, prever, submeter o projeto particular a uma idéia de conjunto.

O plano é esboçado a seguir :o sistema geral de viação proposto adota e amplia o traçado radial existente na cidade, neste sentido, considerado pelos autores como "a remodelação da parte existente".

Para justificar a solução adotada baseiam-se nas idéias de Victor da Silva Freire em um artigo publicado no Almanach do Estado de São Paulo, em 1925.0 trecho citado se refere à regras enunciadas por Stubben em 1893, sobre a forma de adaptar o estado atual de uma cidade a um plano racional de viação.

A citação do artigo denota a forma como os conhecimentos técnicos eram agregados. Assumiam ,em parte, soluções do passado às quais adicionam novas soluções. Para resolver "a parte mais delicada do problema: o centro da cidade" retomam a solução de uma via circular elaborada em 1924 por Ulhôa Cintra, baseada nos ensinamentos de Eugène Hénard.

No último artigo da série publicada no Boletim do Instituto de Engenharia, Ulhôa Cintra e Prestes Maia abordam ,de forma breve, temas que, segundo os autores, afetam o desenvolvimento da cidade: as estradas de ferro, a abertura de bairros industriais e residenciais e a exiguidade da área central de São Paulo. Alguns destes temas terão continuidade no Plano de Avenidas, porém abordados de forma mais desenvolvida e ampliada.

Prestes Maia e Ulhôa Cintra pretendem um papel mais atuante da Prefeitura na definição das diretrizes de expansão da cidade: a criação de bairro industrial na várzea do Tietê, e a abertura de loteamentos para "classes menos abastadas". 0 papel da Prefeitura não se limitaria à previsão de áreas para estas atividades, mas à compra de terrenos na várzea, realizando operações que lhe proporcionariam os recursos para realizar a remodelação da cidade. 
Em 1930, Prestes Maia é mais ousado na solução para o problema de travessia de estradas de ferro na cidade. Desloca-as para a margem do Tietê e aproveita o leito das vias férreas para o traçado do segundo perímetro viário. Já na questão da definição de uma política fundiária municipal sua postura é mais conservadora. Limita-se a propor um papel normativo, indicando áreas de localização para habitações populares através de um zoneamento da cidade.

Os textos escritos em co-autoria por Ulhôa Cintra e Prestes Maia representam o momento de transição entre as idéias de Victor da Silva Freire e o novo modelo urbanístico adotado para a intervenção na cidade.

Sob o ponto de vista das propostas de remodelação do sistema viário a adoção do esquema combinando as propostas de Hénard às de Stubben apontam para uma intervenção muito mais radical no tecido urbano, um rompimento com a tradição de adaptação ao traçado histórico das cidades preconizado por Camillo Sitte e adotado por Victor Freire em 1911.

"Joseph Stubben é bem o Haussmannn da periferia" afirma Guy Ballangé em sua breve nota bibliográfica na Exposição "La Ville art et architecture en Europe" 21 No plano que ele faz para a cidade de Colonia ,na Alemanha, articula o sistema viário da parte antiga com os novos bairros que são construídos nos terrenos das antigas fortificações. Largas avenidas retilineas, convergindo para praças de circulação organizam um sistema viário que distribue a circulação intra urbana e suburbana.

Jean Louis Cohen 22 aponta para a linhagem de pensamento que se estabelece entre as idéias de Eugène Hénard e as propostas de Le Corbusier na Cidade Contemporânea apresentada em 1922 e no "Plan Voisin" em 1925. Algumas idéias chave articulam esta herança : a proposta de uma grande avenida cortando Paris, a via elevada e a classificação do sistema viário segundo a circulação e o tráfego .

21 Ballangé, Guy "Joseph Stubben ( 1845-1936) Héritier ou fondateur"in Dethier, Jean et Guilheux, Alain La Ville, art et architecture en Europe, 1870-1993 Paris Ed du Centre Georges Pompidou, 1994 p 134-135

22 Cohen, Jean Louis "Presentation : les visions métropolitaines d'Eugène Hénard"in Henard, Eugène Les transformations de Paris , Paris, L'Enquerre, 1982 
Observa- se a forma como se faz a transferência dos modelos para o caso paulistano. Adotam em parte as idéias adaptando -as ao que é mais conveniente naquele momento. Hénard e Stubben partem de concepções opostas de estrutura viária. No esquema de Hénard todas as vias de expansão e penetração convergem para o núcleo central, para um círculo fechado que ele propõe chamar de perímetro de irradiação; já Stubben considera que as verdadeiras correntes de circulação são as vias radiais que conduzem do centro à periferia e vice-versa. A segunda categoria de vias, segundo Stubben, a que serve para ligar os setores divididos pelas vias radiais. Denomina de ruas anulares ou "rings" de primeira, segunda e terceira ordem.

Os dois modelos têm por concepção orientações diferentes para o desenvolvimento da cidade: o de Hénard converge, adensa; o de Stubben espalha o movimento, se repete indefinidamente através do sistema radial-perimetral.

No Plano de Avenidas a concepção do sistema radial perimetral para a reformulação e ampliação do sistema viário é a mesma desenvolvida em 1925 por Prestes Maia e Ulhôa Cintra

Apresentam também indicações da influência que começam a exercer no urbanismo paulista as idéias de urbanistas americanos. A mais importante é a introdução de princípios de racionalidade e eficiência da administração privada para a administração pública .Critérios como a efíciência e a eficácia dos planos urbanos passam a ser passiveis de averiguação.

No Plano de Avenidas, esta tendência de apresentar os exemplos de experiências urbanisticas americanas, como forma de apoio à argumentação, aparece com maior frequência. Os exemplos são variados e referem-se principalmente a soluções de engenharia viária. Representam a penetração de uma nova fase do urbanismo americano a do comprehensive city planning e o livro Planning the modern city de Nelson Lewis será a principal referência citada.

Nelson Lewis dedica o livro aos engenheiros municipais:"The first men on the ground in city planning as in city building in the hope that it may help them to realize their 
responsabilities and opportunities in determining the manner in wich our cities will develop" 23 o significado desta dedicatória é desenvolvido no último capítulo do livro "The opportunities of the municipal engineer". Lewis exalta a importância do trabalho do engenheiro,segundo ele, pelas direções de crescimento da ciaade e reivindica um novo campo de trabalho para o engenheiro - a administração municipal. Ao procurar garantir um espaço profissional para o engenheiro está , também ,definindo limites para esta competência .Amplia o espaço profissional ao mesmo tempo que reduz o papel ao controle e operacionalização de obras de engenharia na administração municipal. Nesta perspectiva, o casamento é perfeito, ninguém melhor que o engenheiro para ser o responsável pela administração da cidade.

A mesma idéia aparece no Plano de Avenidas, a defesa do campo de atuação profíssional do engenheiro municipal Observa-se que esta posição faz parte de um movimento mais geral entre os engenheiros civis e arquitetos, de definir o seu espaço, não apenas na administração municipal , mas a nível da sociedade civil.

Vamos encontrar este argumento em artigos publicados na época. Em 1928 ,Anhaia Mello defende a criação de uma Divisão de Urbanismo no Instituto de Engenharia, inspirando-se na City Planning Divisison da American Society of Civil Engineers 24 Em outro artigo,publicado em 1929 ,assinado pelo engenheiro Plinio de Queiroz aparece a informação da criação desta divisão, o autor pretende que ela seja o embrião da Associação dos Amigos da Cidade. Os dois engenheiros justificam a criação destes espaços institucionais como forma de difusão do urbanismo junto ao grande público .Na prática este movimento resultou na consolidação de um campo de atuação profissional como podemos observar pelas transformações na estrutura administrativa da Prefeitura de São Paulo.

23 Lewis, 1923 ,opus cit ,p IV

24 Mello, 1928,opus cit ,p 235-240 
6.A cidade moderna do Plano de Avenidas: fluidez, descongestionamento, sem barreiras para 0 crescimento

Em 1930 é publicado o Plano de Avenidas .Foi o documento que orientou a atuação de dois prefeitos de Suo Paulo: Fabio Prado e o próprio Prestes Maia no período entre 1934 e 1945 quanto à remodelação e extensão do sistema viário da cidade. A execução das obras viárias transformam a estrutura urbana de São Paulo e preparam a cidade para o desenvolvimento econômico que se concretizará nas décadas seguintes. Estas características o destacam dos demais planos realizados para São Paulo. Até o final da década de 60, a estrutura viária principal da cidade é a definida neste Plano.

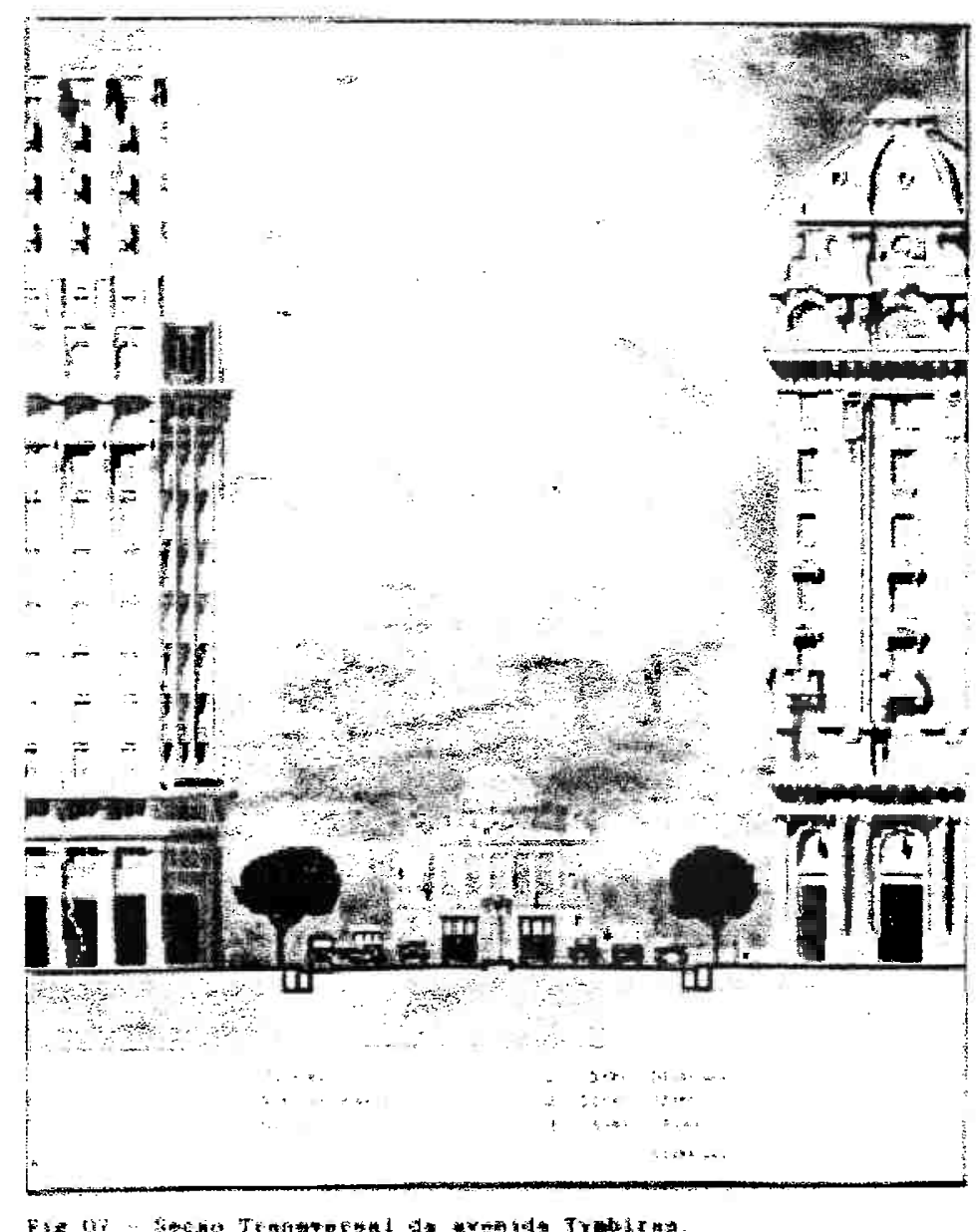

Seção transversal da avenida Tymbiras. Fonte: Maia, Francisco Prestes Estudo de um Plano de Avenidas para São Paulo São Paulo, Melhoramentos, 1930 
O sistema viário projetado no Plano compunha-se de três avenidas perimetrais articuladas por um sistema de avenidas radiais. O sistema perimetral era composto por três anéis viários 0 primeiro inspirava-se nos boulevards interiores de Paris.Denominado Perímetro de Irradiação envolvia o centro antigo e o novo bairro comercial nas encostas do vale do Anhangabaú. Transpor o vale, integrar os dois centros assume naquele momento um significado importante. $O$ comercio mais sofísticado, as sedes de empresas, as atividades culturais já vinham se deslocando para o outro lado do vale.As novas avenidas e os viadutos projetados sinalizavam a importância que este novo centro assumia para a administração municipal.

O segundo anel, boulevard exterior, era traçado em parte sobre o leito das ferrovias Suo Paulo Railway e Sorocabana e atravessava os bairros da Barra Funda ao norte, Higienópolis, Cerqueira Cesar, Paraiso e Ipiranga ao sul. As ferrovias seriam removidas para a marginal do rio Tietê, com os objetivos de ,por um lado, melhorar a circulação de veículos evitando travessias e por outro unificar e racionalizar o serviço ferroviário. Fechando o círculo em torno à área urbanizada na época, o terceiro anel denominado Circuito de Parkways, era composto pelas marginais ao rio Tietê e Pinheiros, seguia até as cabeceiras do Ipiranga , descia o vale do Tamanduateí até a confluência com o Tietê. A margem direita do canal do Tietê era reservada para a relocação das ferrovias e a localização de uma nova Estação Central .Na margem esquerda eram localizadas as vias marginais ligando os parques propostos para a cidade

Unindo estes anéis era traçada a Estrela de Radiais-avenidas que saíam do Perímetro de Irradiação em direção a todos os quadrantes da cidade.

Este sistema radial-perimetral permitia a extensão sem limites da cidade garantindo, ao mesmo tempo, uma integração mais eficiente entre os diferentes bairros.A predominância dos automóveis e ônibus em relação a outros meios de transporte é evidente no Plano.O argumento da fluidez do tráfego é utilizado tanto para justificar o deslocamento de ferrovias como o impedimento do tráfego de bondes nas avenidas.

Prestes Maia defende a crescente intervenção do Estado através : da realização de 
obras, da produção e gestão de serviços urbanos e do estabelecimento de normas para gerir o que se constitui como uso comum e uso privado.Para Prestes Maia, o Estado deve se distanciar do jogo das forças de mercado e assumir o duplo papel de provedor e árbitro: por um lado deve garantir os recursos para a realização de obras através da criação de impostos e taxas;como árbitro deve evitar os abusos que possam prejudicar tanto o interesse público como o interesse privado.

As observações de Prestes Maia sobre a legislação que regulamentava a questão das desapropriações suo um exemplo desta nova postura:"Tudo se resume em por um lado garantir o interesse público, e por outro evitar contra o particular abusos de uma legislação avançada"Remete à esfera do judiciário o arbítrio de tal questiono juiz de carreira, esclarecido, independente, affeito às leis e à sua interpretação" afastado das pressões de interesses particulares deve substituir "o bom varão leigo e ocasional" 25 .

Para realizar o conjunto de obras viárias proposto no Plano de Avenidas, Prestes Maia propõe que os recursos financeiros venham de fundos públicos:rendas ordinárias, empréstimos e taxa de melhoria.Pode-se notar que a participação da iniciativa privada como empreendedora é totalmente deixada de lado.Na questão dos transportes urbanos, defende cada vez mais a coordenação pela Prefeitura da gesto deste serviço: definição de tarifas, de abertura e extenso de linhas de bondes e ônibus etc.

No Plano de Avenidas a defesa da engenharia municipal aparece com maior clareza no capítulo referente ao sistema de transportes.É nesta área que o conflito de atribuições entre as empresas concessionárias de serviços públicos e a administração municipal começa a ganhar consistência a nivel da explicitação de interesses e assume contomos de um debate público.Prestes Maia apresenta longas descrições do sistema de transportes de Suo Paulo e de experiências estrangeiras. Critica os pareceres de consultores estrangeiros contratados pela administração municipal 26 e procura

25 Maia, 1930,opus cit ,p. 16

26 A crítica de Prestes Maia à consultoria de especialistas estrangeiros se expressa com maior contundência ao argumentar no Plano de Avenidas contra o plano da Cia Light \& Power de extensåo de linhas de bondes subterrâneos para a área central de São Paulo. 
demonstrar o conhecimento técnico necessário para que as novas funções venham a ser desempenhadas pelo engenheiro municipal.

As opiniões de Prestes Maia expressas no Plano de Avenidas apontam para uma mudança de postura em favor de um aumento de intervenção do Estado.Esta mudança foi se constituindo, entre os urbanistas paulistas, ao longo dos vinte anos que separam os textos de Freire e Prestes Maia.Este movimento de expansão (enquanto intenção de intervenção )aparece tanto na formulação quanto na prática do planejamento urbano e se reflete em formas diferentes de estrutura da administração municipal. Uma forma se refere à ampliação direta de órgãos da administração pública , a outra se refere à ampliação indireta através da criação de comissões técnicas.Prestes Maia não menciona,como o fizeram Victor Freire e Anhaia Mello, a possibilidade da mediação da sociedade civil junto a esta crescente intervenção do Estado.

No decorrer da leitura do Plano de Avenidas em alguns mumentos somos surpreendidos pelas propostas de criação de espaços públicos, conjuntos arquitetônicos em pontos estratégicos na cidade. Destacam-se das demais propostas a começar pela designação que recebem, o estilo ao descrevê-las e as aquarelas que as ilustram.

Representam um projeto de proposta estética para algumas áreas de alto valor simbólico da cidade. São conjuntos de edificios e praças que transformariam o vale do Anhangabaú na "sala de visitas "da cidade; a praça da Sé ligada a uma pequena reprodução da Place d'Etoile na extremidade do parque D.Pedro e uma nova Estação Ferroviária,às margens do Tietê, nas "portas da cidade moderna" (talvez uma resposta à proposta de Alfred Agache à"porta de entrada"do Brasil projetada no Rio de Janeiro).

Prestes Maia procura corresponder nestes novos espaços projetados as funções sociais da vida urbana: a representação política, eclesiástica, o trabalho, a circulação, o lazer. É o momento que ele projeta e sonha a cidade à Haussmann :a cidade das grandes perspectivas, a cidade dos pontos focais. Entretanto, ao procurar traduzir 
nestes novos espaços urbanos as redes de relações que se estabelecem e se entrecruzam na cidade moderna, demonstra um descompasso entre o planejamento urbano e o projeto arquitetônico.

A proposta de remodelação do sistema viário traduz o novo ritmo de crescimento da cidade industrial. Ele projeta a cidade modema de sistemas de vias perimetrais que se repetem indefinidamente e lançam São Paulo extra-muros da confinação que a mantinha as barreiras representadas pelos rios Pinheiros e Tietê. Nos conjuntos arquitetônicos retorna aos valores estéticos do passado, sem vínculos com a matriz do movimento da arquitetura moderna que tem um nexo orgânico e deliberado com a sociedade industrial capitalista. Este vinculo é evidente na corrente do urbanismo modernista tema que desenvolvemos no capítulo seguinte.

\section{Planos de conjunto : a circulação de idéias nas cidades brasileiras}

No mesmo período em que estava sendo elaborado o plano para São Paulo, no Rio de Janeiro o arquiteto e sociólogo Donat Alfred Agache, secretário geral da Société Française des Urbanistes, e professor do Institut d 'Urbanisme foi contratado pelo prefeito para uma série de palestras e em seguida para desenvolver um plano para a cidade do Rio de Janeiro .

A palavra urbanismo, segundo Bruant 27 ,foi introduzida na França por volta de 1910. Atribue-se o neologismo a Pierre Clerget no artigo "L urbanisme, étude historique , géographique et économique". Entretanto, será Donat Alfred Agache quem empregará o termo para qualificar um conhecimento e uma atividade que envolveria "A pesquisa de todos os elementos que fazem parte da organização de uma aglomeração urbana". Agache 28 acrescenta "Não é apenas uma ciência e uma Arte , é também uma adaptação sociológica".

27 Bruant, Catherine "Donat Alfred Agache : urbanismo, uma sociologia aplicada"in Ribeiro, Luiz Cesar e Pechman,Robert(org) Cidade , povo e nação : gênese do urbanismo moderno, Ed Civilização Brasileira, 1996.

28 apud Bruant, Ctaherine, opus cit, p 195 
Esta afirmação refletia em parte uma característica do urbanismo que surgia na França da associação entre diferentes saberes, em particular entre a arquitetura e a sociologia. Uma das principais instituições que vai reunir profissionais de diferentes origens: arquitetos, sociólogos , higienistas , será , desde 1907 ,a Seção de higiene urbana e rural do Museu Social .0 museu ,uma organização não govemamental , com sede em Paris organizava concurso de projetos, reunia em sua biblioteca informações e documentos e financiava viagens de pesquisa ao exterior. Constituía-se em um fórum importante de discussão das questões urbanas na França e no exterior. Organizava-se em sessões temáticas ,como a de higiene rural e urbana ,que teve como questões centrais de debate, até os anos 20 , a utilização da área das antigas fortificações em torno da cidade de Paris e a regulamentação de planos de extensão.

Em 1911 é criada a SFU Société Française des Urbanistes, sinalizando a crescente institucionalização da atividade profissional. A primeira geração de urbanistas ${ }^{29}$ é na sua maioria formada por arquitetos da École des Beaux Arts, a alguns deles como Henri Prost havia sido conferido o Grand Prix de Rome Participam ativamente de concursos internacionais como o para Camberra na Australia ou o Concurso para a Região de Berlim.

A ação das duas instituições o Museu Social e a Société Française des Urbanistes contribuiu para que fosse elaborada a lei Comudet, promulgada em 1919e modificada em 1924 que dispunha sobre a obrigatoriedade de realização de planos de ordenamento (aménagement) embelezamento e extensão para toda a cidade francêsa com mais de 10000 habitante. A promulgação desta lei abriu um vasto campo de trabalho para os urbanistas franceses .Explica em parte a institucionalização crescente da atividade , inclusive em termos de ensino. Conforme observa Gaudin 30 “a estruturação de práticas profissionais interagindo com as formas de recrutamento e de formação foram função . principalmente de uma codificação administrativa para a elaboração de planos de urbanismo. Esta institucionalização aparece às vezes como elemento de reconhecimento do campo profissional e como fator de diferenciação e de

29 Louis Bonnier ,Donat Alfred Agache,Leon Jaussely,Henry Prost, entre outros.

30 Gaudin, Jean Pierre "A l'avance avec méthode .Savoirs, savoir- faire et mouvement de professionalisation dans I 'urbanisme au début du siècle" in Sociologie du travail , no 2, 87 
hierarquização de práticas"

O autor está se referindo especificamente ao período de 1909 a 1929, na França ,quando se legitima a idéia de plano Neste período haveria uma disputa entre engenheiros e arquitetos quanto à proeminência do papel a desempenhar na nova atividade que se formava .Nos primeiros projetos de lei de planos de urbanismo 0 papel de concepção é atribuído, sem discussão, ao arquiteto. $O$ que não impediu que outras formações reivindicassem que o conteúdo dos planos recaísse sobre seus campos de especialidade como no caso dos engenheiros reivindicando a primazia no projeto das redes de infraestrutura

Os termos arte e ciência conjugam-se para definir urbanismo segundo a concepção dos primeiros urbanistas franceses como vimos em Agache .Esse binômio sugere a combinação de duas formações : a artística do arquiteto e a racional do engenheiro. Gaudin interpreta, porém, arte não como a atividade artística, mas como se usava na época para definir homme de l'art - o que pratica, o que detem a prática do oficio. Neste sentido unindo ciência e arte estava se sugerindo a combinação do saber e do saber fazer, do conhecimento e da prática profissional. Esta relação seria na época ,segundo o autor, bastante explorada tanto nas questões relativas a tecnicas de infraestrutra reunindo conhecimentos técnicos, como por exemplo captação, adução e distribuição de água ,com conhecimentos científicos, como bacteriologia, epidemiologia. Estariam também na base dos projetos de arquitetura e urbanismo reunindo conhecimentos que permitissem o recurso a modelos globais de explicação das dinâmicas sociais para a definição de leis gerais de urbanização. $O$ recurso à ciência ,naquele momento de formação de uma área de conhecimento, é fator importante de legitimação. 31 .

Na definição de Agache sobre o urbanismo é conferida primazia à sociologia - um meio de intervir no social. Esta forma de entender o urbanismo é uma caracteristica importante entre estes primeiros urbanistas reunidos no Museu Social e que através da

31 É interessante observar que permanece neste campo a indefinição e a competição entre diferentes competências profissionais : a arquitetura, a engenharia, a geografia e a sociologia 
reforma urbana pretendiam a reforma social.

O ensino de urbanismo se inicia em 1919 quando é fundada a École des Hautes Études Urbains, com os cursos A arte do engenheiro municipal , ministrada por Georges Bechman; Urbanismo, ministrada por Louis Bonnier a partir de 1920 e Arte urbana por Leon Jasussely .Conforme descrito anteriormente, de 1917 a 1923 funcionou a École Supérieure d'Art Public, sendo Louis Bonnier o presidente do Conselho de professores.

Em 1924 é criada a instituição que conformará de forma mais permanente o ensino de urbanismo-o Institut d'Urbanisme de Paris, que existe até hoje na Universidade de Paris.

No caso do plano para o Rio de Janeiro, Agache mantem, durante três anos, um escritório técnico no Rio para elaborar os estudos e propostas .Esta extensão de atividades além mar pode ser interpretada como a procura de novos mercados de trabalho e também pela possibilidade que paises, como o Brasil,com legislações urbanísticas menos consolidadas representavam de experimentação de novos instrumentos urbanisticos.

Ele fora escolhido entre quatro nomes para dar uma série de palestras. $O$ tema central é urbanismo. Para Antonio Prado, prefeito do Rio, que o contratara, ele estaria convencendo a opinião pública sobre a necessidade de disciplinar o futuro. ${ }^{32}$ Para o meio técnico profissional brasileiro ele estava divulgando um conceito ainda recente e de uso restrito e que estava substituindo gradualmente a palavra melhoramentos Tratava-se entretanto de tarefa mais ambiciosa , não se referia apenas à intervenção na cidade. Propunha conceituar uma área de conhecimento na confluência da ciência e da arte . "é uma ciência e uma arte e sobretudo uma filosofia social .Entende-se por urbanismo, o conjunto de regras aplicadas ao melhoramentos das edificações, do arruamento, da circulação e do descongestionamento das artérias públicas. É a

32 conforme a revista Le Maitre d'Oeuvre, Revue Française d'Urbanisme,no 33 , avril, mai 1929,Numéro spécial sur le Rio de Janeiro p 30. 
remodelação, a extensão e o embelezamento de uma cidade , levados a efeito, mediante um estudo metódico da geografia humana e da topografia urbana sem descurar as soluções finaceiras"Uma ciência para a compreensão do funcionamento das cidades, que teriam funções análogas às do corpo humano e o plano enfocaria as três funções : respirar , circular e digerir.

O plano para o Rio se vale de uma série de estudos preliminares, que incluem a história econômica e social e levantamentos aero- fotogramétricos do sitio. Sobre esta base cartográfica ele traça os principais eixos do sistema de circulação (ruas , avenidas auto-estradas, transportes urbanos coletivos, metro, ferrovias ) aeroporto e projeta a repartição de espaços públicos (edificios e praças) sistema de parques incluindo um parque nacional.

Agache reune,também, os estudos anteriores elaborados, o que the valeu uma polêmica acusação de plágio 33 . Propondo pela primeira vez um "plano diretor"reune as previsões necessárias de adução de água, esgoto, controle de inundações .Desenvolve a característica de grande porto industrial e comercial criando novas bacias na Baixada Fluminense destinadas ao comercio, depósitos, construção naval e tambem um vasto espaço perto da Ilha do Governador para um aeroporto. Resolve a questão ferroviária organizando uma estação central no lugar da estação Leopoldina e prevendo a ligação direta com o bairro de Copacabana 34 .

Do plano, as propostas de conjuntos monumentais são, talvez , as mais conhecidas e divulgadas no meio profissional. Referimo-nos não apenas às aquarelas do conjunto de predios, avenidas e praça para a Esplanada do Castelo mas também o uso de imagens quando projeta no Rio "As portas do Brasil". Agache tem a ambição de dotar o Rio de Janeiro de um conjunto monumental que dará às obras na cidade a nota grandiosa que the falta enquanto capital de um pais e oferecerá ao visitante chegando

33 ver texto de Silva L. "A trajetória de Donat Alfred Agache no Brasil"in Ribeiro ,LC e Pehman, R Cidade Povo e Nação Gênese do Urbanismo moderno ed Civilização Brasileira, Rio de Janeiro, 1996 p 405.

34 conforme a revista Le Maitre d'Oeuvre, Revue Française d'Urbanisme,no 33 , avril, mai 1929, Numéro spécial sur le Rio de Janeiro p 30 e 31. 
pelo mar uma fachada correspondente à importancia da cidade" 35 Inflama a imaginação de urbanistas de outras cidades que procuram reproduzir imagens com igual apelo é a "Sala de Visitas"para o vale do Anhangabaú, em São Paulo,projetada por Prestes Maia em referência explícita ao Rio de Janeiro.

Mas não apenas os especialistas estrangeiros eram contratados, alguns engenheiros e arquitetos, como os paulistas Prestes Maia e Ulhôa Cintra e os cariocas Attílio Correia Lima, Washington Azevedo e Armando de Godoy serão chamados a projetar novas cidades e para dar consultorias. Os projetos para o bairro de Santo Antonio, na área central da cidade de Recife, são um exemplo de projetos polêmicos que envolveram eqipes locais e as disputas ultrapassaram as fronteiras do Estado .

Em 1927, Domingos Ferreira, engenheiro da Secão Técnica da Prefeitura do Recife propõe um projeto de abertura de avenidas e desapropriações no bairro.Este projeto é submetido ao parecer de uma Comissão do Clube de Engenharia que apresenta duras críticas $^{36}$.

Sabendo desta polêmica o engenheiro-arquiteto, Nestor de Figueiredo, pernambucano radicado no Rio de Janeiro e que já havia trabalhado com Agache, entra na discussão ao apresentar um esboço de um plano urbanístico para a cidade no IV Congresso Panamericano de Arquitetos, realizado no Rio de Janeiro em 1930. Este trabalho the vale um convite do Prefeito Lauro Borba para vir ao Recife proferir uma palestra sobre suas idéias acerca da remodelação do bairro. Nestor de Figueiredo terminou por conseguir firmar um acordo, sem ônus para a Prefeitura, no qual apresentaria um Plano para o Bairro de Santo Antônio.

35 conforme a revista Le Maitre d"ouvre, Revue Française d'Urbanisme,no 33 , avril, mai 1929, Numéro spécial sur le Rio de Janeiro p 31.

36 o parecer do eng. José Estelita separa os engenheiros por categorias aqueles, funcionários municipais, que se ocupam do dia a dia e aqueles, como ele ,em instituições de classe , capazes de uma visão abrangente .Nas suas palavras, critica entregar "os planos geraes, os planos de embelezamento de uma cidade a funcionários municipaes que vivem ocupados com detalhes de cousas diarias.(...)jamais terão tempo para grandes reflexões para deliberação muito seria, de alta responsabilidade e que exijam uma larga visão de futuro 
Em janeiro de 1932, Figueiredo ap resenta seu Plano de Remodelação do Bairro de Santo Antônio. Tal plano consistiu basicamente em um novo desenho para o bairro, que, segundo ele, deveria ser estudado em função da cidade como um todo. Neste plano, segundo Diniz Moreira 37 , podemos encontrar uma forte influência de Agache: o aspecto maciço, cênico, com muitas perspectivas e visuais, avenidas em $Y$, praças e conjuntos monumentais e, sobretudo, a idéia de que o edificio forma a cidade. Outros temas de Agache constantes no plano para o Rio de Janeiro estão também presentes como a Entrada do Brasil e a idéia de criar-se um bairro exclusivamente de negócios.

Figueiredo apresentou ainda um plano para o Recife "Plano de Remodelação e Extensão da Cidade do Recife"que constava basicamente de zoneamento e sistema viário. Em relação à este último, foi adotado pela primeira vez o sistema viário radialperimetral, comunicando zonas urbanas periféricas a partir de um conjunto de avenidas que cruzavam-se em praças e nós espalhados por vários pontos do território.Em relação ao zoneamento, Figueiredo propõe zonas comerciais e de serviços diferenciadas para o Bairro do Recife e para o de Santo Antônio. Propõe ainda zona industrial e zonas residenciais segundo a densidade de urbana, além de um bairro universitário nas imediações do Parque 13 de Maio, um sistema de parques e jardins, uma proposta de legislação e um bosque margeando o canal principal que marcaria o limite entre o centro expandido e a zona estritamente residencial.

O plano de Figueiredo é submetido ao parecer do engenheiro Francisco Prestes Maia de São Paulo e Washington de Azevedo do Rio, a pedido Prefeitura de Recife. Após a não aprovação do plano de Figueiredo pela Prefeitura, é chamado o urbanista Attílio Correia Lima para novo projeto.Em agosto do mesmo ano, ele apresenta o plano para a cidade. $O$ sistema viário é também o radial-perimetral, procurando sempre que possivel conservar a estrutura existente. $O$ urbanista alega que desta forma diminuiria os custos, eliminaria a excessiva convergência para o centro e reduziria o tráfego. 0 ponto marcante do projeto foi a disposição das perimetrais, seis ao todo, enquanto as duas primeiras situavam-se ainda no núcleo central, perfazendo uma espécie de

37 Diniz Moreira ,Fernando "A aventura do urbanismo moderno na cidade do Recife, 1991965 " in Leme,Maria Cristina da Silva (coord) opus cit p 141-166 
perímetro de irradiação, outras três ligavam bairros então suburbanos e a última cortava zonas periféricas extremas não adensadas. Partindo das duas primeiras perimetrais encontrar- se ía um conjunto de 5 vias radiais que se dirigiriam para o interior, estruturando do território urbano.Também o plano de Attilio Corrêa Lima não é aprovado .

Em 1943, a Comissão do Plano da Cidade chama o urbanista paulista João Florence de Ulhôa Cintra. Ele procura identificar da mesma forma como o fizera para São Paulo, em 1924, um circuito de avenidas existente, ou a projetar, para formar o que denomina o perímetro de irradiação .Este perímetro era ,também, inspirado no esquema desenvolvido por Eugène Hénard, para Paris 38 .

Enquanto que em São Paulo existiam os vales para dificultar a implantação do perímetro, em Recife, a dificuldade era imposta pelos rios que cortam a cidade. Assim, para rearticular os bairros centrais, Cintra propôs um aterro em cima dos bancos de areia por vezes emergentes na bacia de Santo Amaro.

Comparando os planos de Nestor de Figueiredo, Attilio Correa Lima e Ulhôa Cintra, Pontual ${ }^{39}$ acentua os pontos de convergência que ao final não são apenas de Recife mas dos planos elaborados para as cidades neste período: o modelo radial - perimetral e a presença de sistemas de parques e jardins .Acrescentaria aos pontos observados por Pontual, a separação entre os diferentes tipos de transporte, a circulação do automóvel e ônibus a diesel sobre pneus e a circulação sobre trilhos por bonde e trem.

A elaboração do Estudo de um Plano de Avenidas para a cidade de São Paulo é sem dúvida um marco na trajetória profissional e política de Prestes Maia. A partir da divulgação e premiação deste estudo, em 1930, no $4^{\circ}$ Congresso Pan Americano de Arquitetos no Rio de Janeiro, é reconhecido como um especialista e vai ser chamado

38 Cintra, João Florence de Ulhôa. "Sugestões para orientação do estudo de um plano geral de remodelação e expansão da cidade de Recife". Prefeitura Municipal Recife, Arquivos, 10 numero, 1943, Recife.

39 Pontual, Virginia "O saber urbanístico no Governo da Cidade: uma narrativa do Recife das décadas de 1930 a 1950, tese de doutoramento, FAU USP , 1998 
para colaborar nos projetos e planos urbanísticos de várias cidades brasileiras. Ele o faz, através de seu escritório, como no parecer para o plano de Recife ou como funcionário do DOP ,no plano para a cidade de Campinas.

O modelo radial perimetral adotado em Recife é modificado no estudo para Campinas. Prestes Maia propõe como solução para resolver a circulação convergente a abertura de uma avenida central, no lugar do perímetro de irradiação .

No rascunho da Exposição Preliminar que faz para o plano de urbanismo de Campinas o primeiro ponto abordado é o que ele denomina "Entrada da Cidade". No Plano de Avenidas já aparecia essa preocupação de marcar com conjuntos arquitetonicos alguns lugares de alto valor simbólico para a cidade. Em São Paulo ele propunha as Portas da Cidade acontecendo em uma grande Estação Central de estrada de ferro situada às margens do rio Tiete .No vale do Anhanagabaú era projetada a Sala de Visitas da cidade em contraponto a Porta do Brasil proposta por Agache para o Rio de janeiro.

Para Campinas ,a entrada demarcada por "portal e pylones" simboliza a divisão do município.Mas a preocupação não é apenas estética pretende também" aplicar o mais possivel as conclusões modernas sobre rodovias principais: previsão de alargamento para no mínimo quatro vias, perimetral externa tratada como parkway, parques, grandes radiais"Este sistema viario em malha formado por radiais e perimetrais seria preenchido por unidades residenciais (neighbourhood unit) unidades alto sustentaveis ao menos para as atividades do bairro. Estas unidades assemelhando-se a cidades-jardim invertidas, com a zona residencial no centro e a comercial na periferia permitiriam a definição dos princípios de um zoneamento permanente. 


\section{Na primeira gestão de Prestes Maia a transformação de São Paulo 40}

Quando aceita o convite do interventor de São Paulo, Adhemar de Barros, para ser prefeito da capital em 1938 inicia uma longa e importante carreira política .É o início de um período de intervenções radicais na estrutura urbana da cidade de São Paulo. Cinco anos, aproximadamente, separam a elaboração do Plano de Avenidas e a utilização deste documento como base para a atuação das administrações municipais. Neste periodo ocorrem transformações no quadro político e econômico nacional e estadual com reflexos no âmbito municipal.

A crise do café,em 1929 e a revolução de 30 têm sido consideradas como os marcos da transição da denominada República Velha ou Primeira Republica e o novo regime político que se instala com o golpe militar de Getúlio Vargas em 1937.Dois aspectos destes acontecimentos são importantes para se compreender as relações particulares que se darão ao nível local:a passagem de uma atividade econômica em que o centro dinâmico é a atividade agrícola para exportação para a atividade industrial;o rompimento da organização política descentralizada, apoiada no alto grau de autonomia dos estados federados em favor do fortalecimento do poder central.

Esta passagem,tanto em termos políticos como econômicos ,não pode ser vista, simplesmente, como uma relação de oposição ou complementaridade ,mas como uma relação de contradição. Esta relação de contradição estaria nas próprias origens da formação do capital cafeeiro,na existência de outras atividades, incluindo a indústria, não diretamente vinculadas à exportação,mas articuladas à expansão da produção cafeeira.

“A crise de 29 e a grande depressão dos anos trinta, ao darem à industria posição de crescente importância, vinham, portanto, acentuar e confirmar os rumos do

\footnotetext{
40 Retomamos aqui a interpretação desenvolvida na tese de doutoramento, sobre o quadro politico e economico que propicia a implantação do plano de Avenidas e as transformações na estrutura urabana decorrentes . Ver Leme ,Maria Crsitina da Silva:,"Re Visão do Plano de Avenidas : 1930 um estudo sobre o planejamento urbano em São Paulo"FAU USP , 1990
} 
desenvolvimento do capital cafeeiro.(..)A partir de então as diversas frações de capital assumem sua própria identidade, as ligações entre frações se tornam tênues :parece possivel a partir de 1930, encontrar uma burguesia "bancária",uma burguesia agrária, uma burguesia comercial."41

No plano político,em especial na organização de partidos políticos, podemos perceber a correspondência destas transformações que vinham ocorrendo a nível econômico. Micelli 42 mostra que a expansão das organizações políticas ao longo dos anos vinte e trinta articula-se às transformações das relações de força no interior do circuito dirigente oligárquico. $O$ autor caracteriza o período de 1901 a 1926, como um período de concorrência entre grupos em tomo da direção do PRP.A criação do Partido Democrático, em 1926 congrega a maioria dos grupos dissidentes em torno de um programa comum

Nesta perspectiva ,a Revolução de 30 não significa a derrota da oligarquia cafeeira como uma totalidade, mas apenas daquela fração cuja atividade, como bem marcou Saes, centrava-se no café enquanto atividade predominante e manifestação ideológica.

A implantação de um Estado forte e centralizado, a partir de 1937, significou de fato não a exclusão de interesses econômicos dominantes do período anterior mas sim uma redefinição de canais de acesso e influência com o poder central.

As observações de Prestes Maia 43 , no relatório sobre as obras realizadas quando prefeito de São Paulo,sâo um exemplo evidente do pensamento tecnocrático que passa a dominar as novas organizações políticas. Prestes Maia atribui a esta nova forma de

41 Saes,Flavio Azevedo Marques de "A grande empresa de serviços públicos na economia cafeeira"São Paulo, Hucitec , 1986,p277

42 Micelli , Sergio opus cit , 1979

43 "Este acervo de concretas realizaçoes comprova de um modo insofismavel,no campo do municipalismo,a excelencia do regime administrativo e das diretrizes implantadas pelo Presidente Vargas, pois nâo, se conceberia no regime das disputas demagógicas, dos embaraços formalisticos e da incerteza financeira"Maia,Francisco Prestes "Os melhoramentos de São Paulo "São Paulo,Prefeitura Municipal de São Paulo, 1945,pl 
organização e ao silêncio das instâncias de participação política o êxito de sua administração.

De acordo com esta visâo,o fortalecimento do poder central só tem condições de se realizar a partir de uma hegemonia construida previamente na sociedade civil. A nível ideológico, as camadas médias têm um papel importante na difusão dos valores da nova classe hegemônica.

As camadas médias urbanas já vinham ocupando desde a Primeira República, os cargos mais elevados das estruturas administrativas (profissionais liberais) e passam a ocupar,também,os postos criados pela nova organização burocrática implantada tanto a nível federal, como a nível estadual e municipal.

Identificados com valores da classe dirigente (com quem mantinham vínculos de família e de negócios), reproduzem e difundem esses valores em um novo quadro econômico e político em que as pressões de grupos dissidentes não conta com canais de representação.

Oliveira 44 observa que quando a "industrialização começa a ser o motor da expansão capitalista no Brasil, ela tem que ser simultaneamente urbana e tem que ser fundamentalmente urbana porque não pode apoiar-se em nenhuma pretérita divisão social do trabalho no interior das unidades agricolas"Isto significava que as indústrias para a produção de um bem não durável de consumo (o exemplo utilizado pelo autor é a industria Matarazzo) precisavam instalar dentro de si, toda uma complexa divisão social do trabalho, desde a produção de bens de capital até as atividades de apoio à comercialização e distribuição .

Esta concentração de diferentes atividades em uma única unidade industrial exigia, segundo Oliveira, por um lado alto grau de capitalização, o que explicaria a concentração de capital e a tendência à formação de oligopólios e conglomerados e dialéticamente, baixa capacidade de acumulação em função da baixa produtividade do

44 Oliveira , Francisco “O Estado e o urbano" Revista Espaço \& Debates no 6, 1982 p42 
trabalho.A abertura de novos postos de trabalho em função deste processo particular de industrialização atraiu à cidade grandes levas de migrantes .

A casa alugada, e especialmente o cortiço, foi durante as primeiras décadas a forma de moradia das classes de renda mais baixa. Com o aumento da população urbana em função do crescimento da atividade industrial surgem novas formas de habitação e que a ,nosso ver,concorrem para a transformação na estrutura urbana da cidade de São Paulo:a expansão da área urbanizada e a localização na periferia da cidade, das habitações dos trabalhadores. 0 aluguel ainda é a forma dominante de acesso à habitação,porém tem início neste período a solução que se tornará cada vez mais difundida e dominante ,a partir dos anos 60 , a auto-construçâo da habitação na periferia da cidade 45 . Cabe assinalar que esta transformação só foi possível com a transformação do sistema de transportes coletivos. A rigidez dos trilhos dos bondes é inicialmente complementada e gradualmente substituída pelo ônibus. A malha viária necessária a esta mudança foi implantada de acordo com os princípios de um sistema viário radial proposto no Plano de Avenidas e implantado nas administrações de Fábio Prado e Prestes Maia.

A localização na periferia da cidade das habitações das classes de renda mais baixa,constatação reafirmada pelos diferentes estudos urbanos, 46 está a nosso ver, relacionada aos dois processos que constatamos ao descrever as obras viárias realizadas pelas administrações municipais no período entre 1934 e 1945 : a verticalização do centro com consequente expulsão das residências de classes mais baixas para a periferia e a integração bairros/centro e bairros/bairros.

As idéias e propostas do Plano de Avenidas apresentam uma correspondência com este quadro de transformações econômicas e políticas esboçado nos seus traços mais gerais.Esta relação pode ser percebida como a expressão de uma combinação de interesses diversos.

45 Como observam Kowarick e Ant, no decorrer da década de 1940, quando Sâo Paulo ultrapassa 2 milhôes de habitantes,já existem sinais evidentes da generalizaçâo da autoconstruçâo no que eram entâo as periferias de Sâo Paulo.p.58.

46 Ver sobre o tema Villaça, 1978,pp238 e239;Kowarick e Ant,1988,pp56 e57; Kowarick e Bonduki,1988,ppl39-140 
A concepção de cidade, implícita nas propostas do Plano de Avenidas ,de ocupação extensiva do solo apoiada em um sistema viário radial perimetral, corresponde, à nível da estrutura urbana, a um padrão de ocupação do solo que se faz de forma cada vez mais extensiva mas que, por outro lado, apresenta a necessidade de uma integração mais eficiente entre os diferentes setores da cidade

O Plano apresenta a incorporação pela própria administração municipal da percepção de uma necessidade de intervenção crescente do Estado direta (provisão de serviços de infraestrutura) e indireta (na gestão de serviços urbanos e como árbitro entre o direito individual e coletivo).

As camadas médias ocupam cada vez mais os postos burocráticos, cabendo a elas legitimar e ampliar este espaço. Neste sentido, a defesa que Prestes Maia faz, no Plano de Avenidas, de um campo de trabalho profissional -a engenharia municipal- nos parece reforçar esta hipótese: a continuidade do planejamento urbano é garantida em parte pela própria necessidade dos engenheiros municipais em preservar as funções e posições conseguidas.

Com a realização das obras viárias nas administrações de Fábio Prado e Francisco Prestes Maia 47 previstas no Plano de Avenidas dois processos que ocorrem em São Paulo neste periodo:a verticalização da área central e a integração dos bairros entre si e com o centro da cidade. As comunicações dos bairros entre si e com o centro, que se davam de forma precária, se transformam, resultando com a melhoria da acessibilidade,em um conjunto mais integrado e articulado.

Fábio Prado, pertencente a tradicional familia paulista,é o primeiro prefeito do período autoritário a exercer um mandato mais longo (1934-1938).Contando com o apoio dos outros niveis de governo e sem a interferência de pressões sociais,e sem as Câmaras municipais extintas em 1930,tem início uma nova fase na administração municipal.

47 O primeiro período que se segue à Revoluçâo de 30 é de grande turbulência política .Ocupam a Prefeitura de Sâo Paulo onze prefeitos de 1930 a 1934, entre eles os engenheiros Luis de Anhaia Mello e Arthur Saboya.Descrevemos as principais características dêsse periodo na dissertaçâo de mestrado.(Leme, 1982 p40). 
Na gestão de Fábio Prado é realizada uma reforma administrativa na Prefeitura.Esta mudança significou imprimir uma nova hierarquia aos diferentes setores, modificar a subordinação de serviços, extinçâo e criação de setores.A antiga Diretoria de Obras é transformada em Departamento de Obras e Serviços Municipais.

O recolhimento do imposto predial passara para a Prefeitura e a situação financeira apresentou um superávit, pela primeira vez, desde 1930 o que permite realizar algumas das obras previstas no Plano de Avenidas. :abertura da avenida Rebuças e da avenida Nove de Julho; inicio das obras do viaduto do Chá e do túnel sob a avenida Paulista e formação do Parque do Ibirapuera. A administração de Fábio Prado prepara as condições administrativas e financeiras para a transformação que Prestes Maia vai imprimir ao assumir a Prefeitura de São Paulo, em 193848.

A relação de obras projetadas, iniciadas e realizadas é bastante extensa. Entretanto, mais do que a quantidade, é o significado das obras o indicador da importância deste período.

A área central da cidade vai receber uma atenção especial. Prestes Maia completa neste periodo as obras do perímetro de irradiação. A concepção é simples e menos ambiciosa do que nos projetos originais de 1924 e 1930:"envolvimento da área congestionada por um anel, de modo a provocar ao mesmo tempo sua expansão superficial, o desvio das correntes diametrais e uma fácil distribuição perimetral do tráfego" 49 .

Prestes Maia persiste nas soluções anunciadas no Plano de Avenidas, mantendo inclusive os mesmos nomes. Além do perímetro de irradiação na área central prossegue as obras do "sistema em Y", um conjunto de três avenidas que, segundo o autor atravessaria toda a cidade ligando o Tietê ao vale do Pinheiros. A conclusão do

48 Um balanço deste período de sete anos de administraçâo pode ser avaliado a partir do relato detalhado das obras realizadas feito por Prestes Maia e publicado em 1945 sob o título "Os Melhoramentos de Sâo Paulo". Este relatório foi publicado pela primeira vez em 1942. Uma segunda versão ampliada foi publicada em 1945.

49 Maia, 1945, opus cit ,p 10. 
viaduto do Chá, construção em concreto, substituíndo a antiga estrutura metálica, projeto de Jules Martin, efetiva a integração entre os dois centros 50 .

A circulação de veículos ganha cada vez mais importância a partir das transformações que ocorrem na área central. Quadras inteiras são derrubadas, áreas verdes reduzidas para "obter mais espaço, passagem e pontos convenientes de retorno para os veículos coletivos e aliviar as praças centrais mais congestionadas, como as da Sé e dos Correios" 51

O Vale do Anhangabaú é o exemplo mais flagrante deste tipo de transformação. Projetado para ser um parque " "a Sala de Visitas de São Paulo" a sua função principal passa a ser a circulação do fluxo de veículos para a zona sul da cidade .Duas vias de circulação ocupam o espaço antes reservado à área verde, reduzida depois das obras, a simples passeios central e lateral.

A realização destas obras em um curto espaço de tempo (dez anos) tiveram um impacto importante na acessibilidade entre a área do triângulo central e o novo centro, do outro lado do vale do Anhangabaú e dos diferentes bairros entre si e com o centro da cidade.

Somekh, ao descrever o processo de verticalização em São Paulo, observa que na área central, a partir do final da década de 20 começa a expansão do triângulo histórico em direção ao chamado centro novo. No período entre a metade da década de 20 e o final da década de 30 ocorre o processo de verticalização, tanto na área do triângulo central,como nos bairros do outro lado do vale do Anhangabaú. Como mostra a autora, a verticalização até 1939 "era um fenômeno tipicamente central e predominantemente terciário" 52. A partir de 1940 observa-se a existência de dois centros, com a importância crescente do novo em relação a colina histórica.

50 A transposiçâo do vale do Anhangabaú era realizada através de dois viadutos :o Santa Efigênia e o do Chá. O novo viaduto do Chá tem aproximadamente $30 \mathrm{~ms}$ de largura, o que mais que duplicava a capacidade do anterior.

51 Maia, 1945, opus cit ,p 12.

52 Somekh, 1989, opus cit ,p 190. 
O segundo período de verticalização em São Paulo, identificado por Somekh (1940 1957) é predominantemente residencial, e os edifícios construídos neste período, localizam-se predominantemente nos bairros próximos ao centro.

Para a ocorrência destes dois processos apontados pela autora concorrem as obras viárias realizadas nas gestões de Fábio Prado e Prestes Maia. O alargamento das vias que compõem o perímetro de irradiação, a construção do novo viaduto do Chá, do viaduto Jacareí, viaduto Dona Paulina e viaduto Nove de Julho concorreram de forma importante para a integração entre os dois centros e a verticalização da área central.

Em 1938, pelo Ato $1366 \mathrm{~m}$, Prestes Maia introduz mudanças na legislação limitando gabaritos em algumas ruas do centro, definindo como observa Somekh ${ }^{53}$, um novo desenho urbano. Esta intenção de controle estético vinculava o limite de um edifício aos vizinhos formando conjuntos arquitetônicos. Em 1941 Prestes Maia introduziu alterações no Código de Obras ampliando o limite das alturas na área abrangida pelo perímetro de irradiação .Segundo Henrique Lefevre 54 , esta legislação incentivou um
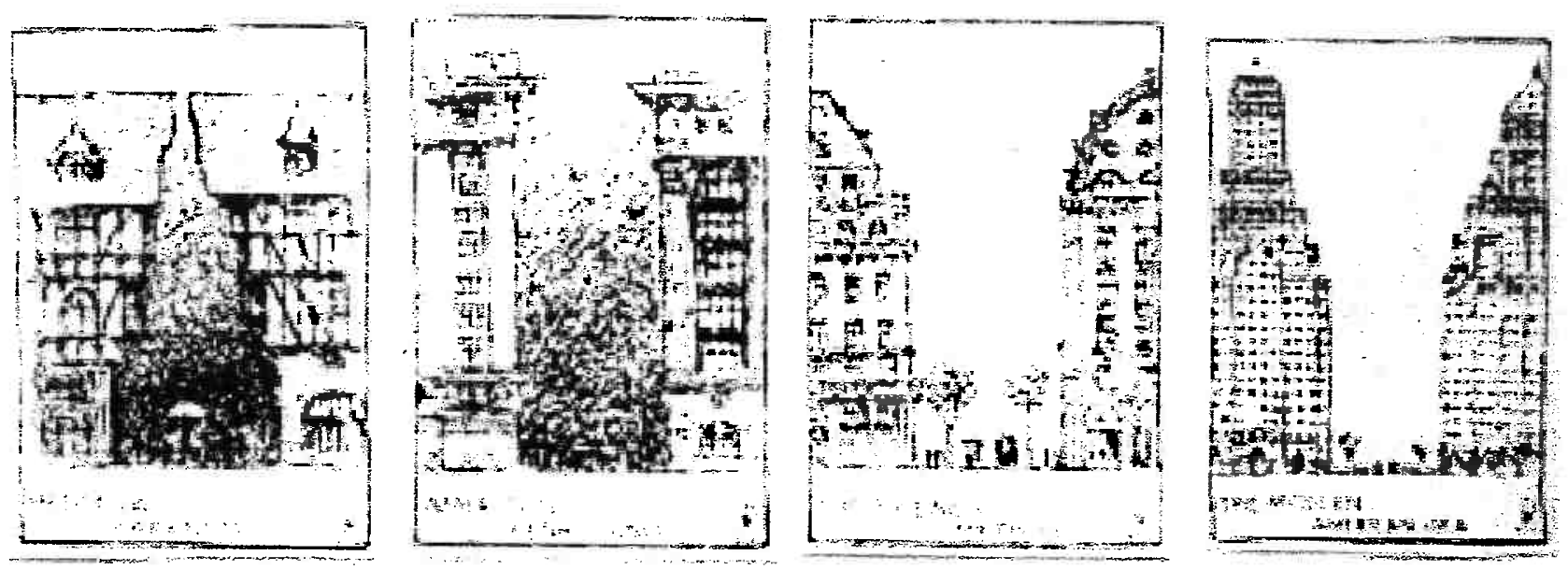

A influência do zoneamento na disposição das edificações. Fonte: Maia, Francisco Prestes Estudo de um Plano de Avenidas para São Paulo São Paulo, Melhoramentos, 1930

\footnotetext{
53 Ver tambem a descrição das ruas atingidas pela legislação in Somekh,1997, opus cit p 133 e 134

54 Lefevre, Henrique Neves"Influência da legislação urbanística sobre a estruturação das cidades .São Paulo, mimeo .Tese apresentada em concurso da Escola de Engnharia Mackenzie, 1951.apud Someck 1997,opus cit ,p 134
} 
novo crescimento da construção civil.

A expansão da verticalização para os bairros em torno à área central estaria mais relacionada às obras do sistema viário radial realizadas no período entre 1934 e 1945 . Correspondem ao processo que identificamos como a integração dos bairros entre si e com o centro da cidade.

As plantas podem iludir um observador desavisado sobre as formas de comunicação que se estabeleciam naquela época em São Paulo. As memórias dos moradores, relatos do cotidiano mostram a existência de "cidades" dentro da cidade 55 .

A história dos bairros e as histórias de vida nos falam do isolamento em que viviam os habitantes dos bairros populares. A ida ao centro para uma compra era muito rara. Os bondes bissextos e as baldeações, passando, necessariamente, pelo centro faziam com que a comunicação de um bairro a outro se desse de forma precária,com tempos de deslocamento muito grandes.

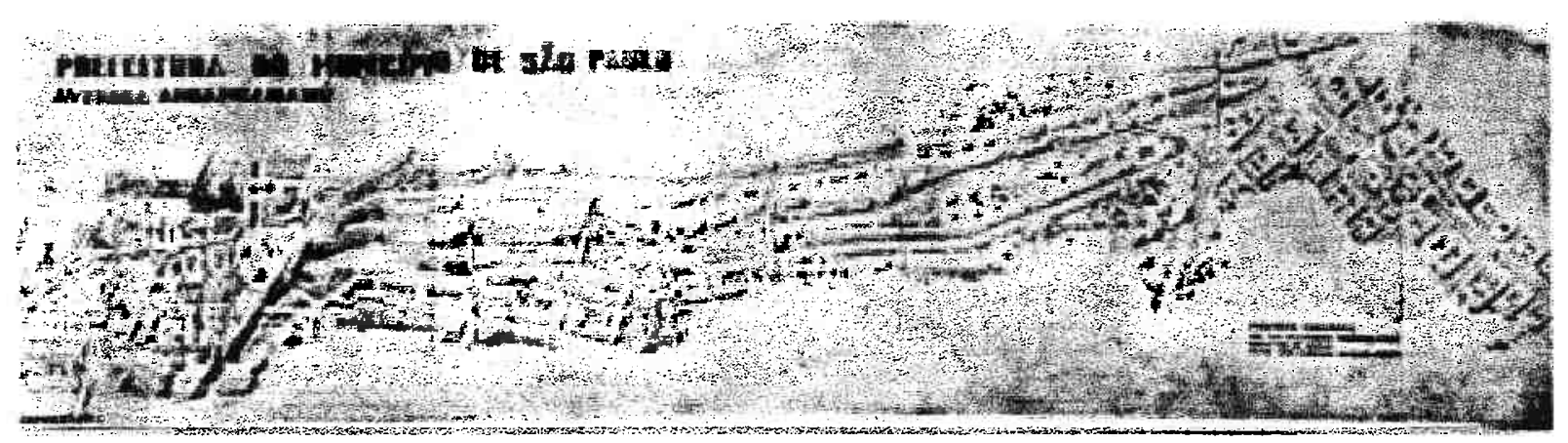

Projeto Avenida Anhangabaú . Fonte: Maia, Francisco Prestes Estudo de um Plano de Avenidas para São Paulo, Melhoramentos, 1930.

55 Para recuperar,em parte,a memória de Sâo Paulo no início do século ver:"As lembranças de velhos" de Ecléa Bosi, "Anarquistas, graças a Deus" de Zelia Gatai;"Novelas Paulistanas" de Antonio de Alcantara Machado;"Um homem sem profissâo. Sob as ordens de mamâe".de Oswald de Andrade. Ver,específicamente sobre a formaçâo dos bairros de Sâo Paulo,as publicaçôes da Secretaria Municipal de Cultura da Prefeitura do Município de Sâo Paulo. 
Constituíam barreiras que separavam o centro dos bairros à leste (Brás, Mooca, Tatuapé) o rio Tamanduateí e as "porteiras" das estradas de ferro. Ao sul, o caminho para Santo Amaro se fazia pela estreita e íngreme rua Brigadeiro Luis Antonio; para o bairro de Pinheiros, os bondes desciam a atravancada e estreita rua Teodoro Sampaio.

Ao norte o transporte para o bairro de Santana se fazia pelo tramway da Cantareira, construído inicialmente para a realização das obras de abastecimento de água da cidade. A abertura da avenida Tiradentes, a construção da Ponte Grande, em concreto,substituindo a antiga e estreita ponte sobre o rio Tietê, ampliavam as comunicações com esta área, que Prestes Maia visualizava como a nova área de expansão da cidade. $O$ início da canalização do rio Tietê integrava à área urbanizada da cidade terrenos da várzea, periodicamente inundados pelas enchentes do rio $\mathrm{e}$ representavam o primeiro passo para a abertura das vias marginais.

$\mathrm{Na}$ zona leste, ligando os bairros industriais ao centro, zona preterida pelos melhoramentos urbanos das administrações anteriores, foram realizadas obras como a canalização do rio Tamanduatei, a nova ponte Pequena,as pontes do Mercúrio, e das Indústrias, ligando o parque $\mathrm{D}$. Pedro ao bairro do Brá s, além do alargamento da avenida Rangel Pestana. Em fase de estudos, acrescentando mais uma ligação do centro com a zona leste da cidade, existia o projeto da abertura da avenida Radial Leste.

Representam novas ligações entre bairros e com o centro: a extensão da avenida Rebouças nos dois extremos (além do rio Pinheiros através de ponte construída em associação da Prefeitura com a Light e, no outro extremo, até a avenida Dr. Amaldo); a avenida Pacaembú prolongada até o rio Tietê; a avenida Paulista ligando a praça Oswaldo Cruz a Rodrigues de Abreu; a Nove de Julho, prolongada através do Jardim América e do Jardim Europa. As principais medidas de sua gestão foram:diminuição da máquina do município (com a diminuição do quadro de pessoal, extinção de cargos e aposentadoria compulsória); abertura de créditos especiais para obras de melhoramentos e desapropriações.

Sem dúvida, muitas destas obras tiveram relação com os loteamentos de classe alta 
que se abriam nesta época em São Paulo. Da Cia City foram beneficiados diretamente com as novas avenidas: o loteamento do Jardim América atravessado pela avenida Nove de Julho, o loteamento do Alto de Pinheiros pela abertura da avenida Rebouças e avenida Pedroso de Morais, os loteamentos do Butantã e Jardim Guedalia pelo prolongamento da avenida Rebouças além do rio Pinheiros e o loteamento do Pacaembú pela abertura da avenida Pacaembú. Ainda da Cia City tornaram-se mais acessiveis a Vila Romana, o Alto da Lapa e Bela Aliança, pela abertura da avenida Dr Arnaldo e a ligação com a rua Cerro Corá. Outros loteamentos de classe alta são também beneficiados por estas ligações viárias, como por exemplo : o Jardim Europa, a Cidade Jardim, o Sumaré e Perdizes.

O tipo de industria que se instala em São Paulo neste período, reunindo dentro de si uma complexa divisão social do trabalho, atraiu à cidade grandes levas de migrantes. Novos locais de residência e de localização de indústrias eram constantemente abertos. $O$ processo de periferização decorre da própria expansão da atividade industrial que cria novos e mais diversificados centros. Entretanto, se como observam pesquisadores 56 , a periferizaçâo decorre do avanço da industrialização, ela só seria possivel com a alteração da estrutura do sistema viário e do sistema de transportes coletivos urbanos. As linhas de ônibus estendem-se até os novos loteamentos não servidos pelas linhas de bondes 57 .

O trabalho desenvolvido por Sampaio 58 identifica a aplicação de excedentes em atividades imobiliárias pelos cafeicultores e pelos industriais desde o final do século XIX. Ela mostra que, na maioria dos casos, a atividade imobiliária era associada a outras atividades econômicas e não era a mais importante. Na década de vinte é possível perceber o desenvolvimento da atividade imobiliária na periferia paulistana, por proprietários de empresas de material de construção, evidenciando o início do

\footnotetext{
56 Oliveira,Francisco 1982 , opus cit ;Kowarick e Ant, 1988, opus cit

$57 \mathrm{Na}$ descriçâo da forma de atuaçâo da Light mostramos que a empresa atendia preferencialmente os loteamentos de classe alta.Existem registros nos arquivos da empresa de reclamaçôes de industriais nâo atendidos nas suas reinvindicaçôes de extensâo de linhas de bondes ao local das fábricas

58 Sampaio, Maria Ruth de Amaral "O papel da iniciativa privada na formação da periferia paulistana"in Revista Espaço \& Debates , no 37 pp 19-38
} 
processo de construção de moradias na periferia em loteamentos populares.

A associação de interesses entre loteadores e empresas de serviços públicos condição necessária para a o desenvolvimento das atividades da Cia. City, foi observado também na abertura de loteamentos industriais, com o acordo da ligação de ramal ferroviário da São Paulo Railway.

A concepção de cidade,implícita nas propostas do Plano de Avenidas de ocupação extensiva do solo estruturada por um sistema viário radial-perimetral,corresponde enquanto estrutura urbana, por um, lado ao novo padrão de ocupação periférico da cidade e, por outro lado,garante uma integração mais eficiente entre os diferentes bairros e o centro da cidade. Prepara-se dessa forma uma estrutura urbana mais integrada e homogênea, condições necessárias à expansão do processo de industrialização que ocorrerá na próxima década.

\section{Luiz Ignácio de Anhaia Mello - a formulação de um pensamento urbanístico}

Muito da historia do urbanismo paulistano que se desenvolveu na vertente da engenharia, se configurou em torno de Luiz Ignácio de Anhaia Mello. Ele entrou para a Escola Politécnica, em 1909, formando-se engenheiro-arquiteto em 1913. Ingressa como professor no primeiro concurso em que participam formados pela Escola Politécnica. $\mathrm{O}$ primeiro lugar foi de Alexandre Albuquerque contratado no mesmo ano e o segundo lugar, de Anhaia Melo que assumiu o cargo para lente substituto em 1918, na 4a Seção de Artes. Em 1922, foi efetivado e até o ano seguinte foi professor das cadeiras "Arquitetura Civil e Higiene das Habitações" e "Composição Geral I (Habitações)" ocupadas anteriormente por Ramos de Azevedo.

Em 1926 assumiu como cated rático as cadeiras "Composição geral I e II", acrescentada ao currículo da Politécnica por ocasião da reforma de ensino, "Estética. Composição Geral e Urbanismo I e II".Foi vice-diretor da Escola Politécnica de São Paulo, em 1928, afastando-se do cargo em 1930 e retornando em 1931. De 1929 a 1930 foi presidente do Instituto de Engenharia, e de 1933 a 1934 pertenceu à sua 
diretoria.

A produção intelectual de Anhaia Mello tem reflexos importantes tanto na formação da disciplina de urbanismo no curso de engenheiro arquiteto na Escola Politécnica e depois no curso de urbanismo da Faculdade de Arquitetura e Urbanismo como na configuração que assume o setor de urbanismo na Prefeitura Municipal de São Paulo.

Ao observarmos a formação e a consolidação tanto do ensino como da profíssão na administração municipal, percebe-se ser precedida por uma serie de escritos de Anhaia defendendo e sustentando bandeiras, às vezes, durante mais de uma década.

Destacam-se três temas nesta trajetória : a defesa da regulação e regulamentação das atividades de produção do espaço urbano; a definição do campo do urbanismo e planejamento urbano na estrutura administrativa da prefeitura de São Paulo e a filiação à vertente de urbanismo que defende uma organização territorial a partir de uma forma de organização social, unindo pensadores tão diferentes como o escocês Patrick Geddes, o ingles Ebenezer Howard, o americano Lewis Munford e o francês Gaston Bardet .

Anhaia Mello, no cargo de vereador de São Paulo59, imprime uma nova forma de atuação da Prefeitura, na gestão do setor de obras viárias. Suas propostas abordam a questão dos parâmetros de projeto, em uma linha de continuidade às críticas de Victor da Silva Freire, à rigidez imposta à largura e ao traçado de ruas e praças, até a necessária articulação das vias de novos loteamentos ao sistema viário existente na cidade. Na gestão de Raimundo Duprat 60 , alguns avanços haviam sido obtidos, admitindo-se os traçados curvilíneos e submetendo à aprovação da prefeitura a abertura de vias. Pela nova lei 1666 de 1913 iniciava-se a prática da continuidade de traçado entre vias abertas e projetadas e alguns cuidados com o nivelamento do terreno.

59 Eleito em 1919 pelo PRP para o período de 1920 a 1923.

60 Conforme relato de Anhaia Mello in "Problemas de Urbanismo, mais uma contribuição para o calçamento" Revista Politécnica no 23, 1927 p 354. 
Defendendo a cobrança de um pagamento de $2 / 3$ das despesas com o primeiro calçamento, ele , Heriberto Siciliano, Luciano Gualberto e Mario Graccho apresentam sete anos mais tarde um projeto de lei que desta forma imprimia uma preocupação nova com os recursos financeiros para a realização de obras viárias . Este projeto modificado dará origem a lei 2611 de 1923, lei de arruamentos como ficou conhecida. Instituíam-se novos parâmetros de projeto reduzindo as obrigações quanto à largura de via , mantendo a aprovação do projeto e a definição do traçado da via principal pela prefeitura, mas não introduzindo a cobrança de uma taxa de melhoria .

Esta preocupação em conceituar a cobrança de um melhoramento pela valorização que incide sobre o imóvel, se insere em uma linha de argumentação de Anhaia sobre os recursos financeiros municipais para realizar as obras de infraestrutura viária. Prestes Maia repete, no capítulo "Recursos Financeiros do Plano de Avenidas" as mesmas quatro alternativas repetindo, sem citar, a argumentação de Anhaia: rendas ordinárias , empréstimo, "o mais popular e mais perfeito dos métodos - a taxa de melhoria ( benefit assessment method) e o excess condemnation - desapropriação de uma larga zona envolvendo o terreno necessário para realizar o melhoramento.

A argumentação em favor da cobrança de uma taxa de melhoria é retomada, em 1945 , no momento em que São Paulo estava sendo transformada radicalmente pela realização das obras viárias na gestão de Prestes Maia na prefeitura de São Paulo.

Em conferência no Instituto de Engenharia 61 e usando como respaldo a Sociedade Amigos da Cidade, Anhaia Mello mais uma vez discute o problema financeiro da prefeitura. $O$ interessante deste artigo é que explicita as divergências entre Anhaia e Prestes Maia sobre a cobrança de taxa de melhoria. Prestes Maia revidara ,em palestra no Rotary Club, as críticas por não ter aplicado, quando prefeito de São Paulo, a taxa de melhoria. Argumentava considerá-la desnecessária e ultrapassada

61 Conferência proferida em 23 de outubro de 1945 e publicada in Anhaia Mello, Luiz Ignácio de "Um plano regulador para o município de São Paulo.Elementos constitutivos do plano"Revista Engenharia no 41 , jan 46 , pp 169-175 
,alem disto atacava Anhaia Mello que também não a teria aplicado nem quando prefeito por duas vezes de São Paulo, nem como secretário de Viação do governo estadual. Anhaia, alem de reproduzir a polêmica termina o artigo defendendo a taxa de melhoria e descrevendo a base legal recente em legislação estadual, para a aplicação a nível municipal.

Anhaia Mello advoga sempre um controle crescente do Estado através da regulação e a regulamentação das atividades da iniciativa privada. Esta posição anti liberal é muito evidente nos mecanismos que propõe de controle das empresas prestadoras de serviços públicos.

“As empresas de serviços de utilidade pública são regulamentadas pelos govemos de todo o mundo civilizado" é como inicia o artigo publicado em 193062 que tem como sub titulo “Os meios de proteção do interesse publico'.

Admitindo que os serviços são produzidos por empresas de capital privado , no Brasil, empresas estrangeiras em regime de monopólio, ele mostra como necessário o controle rigoroso pelo poder público das atividades das empresas. $O$ caso exemplar em que discute estas teses é a renovação do contrato de transporte público pela Light em São Paulo.

Não apenas as experiências citadas são de cidades americanas mas recorre ao parecer do especialista John Bauer, "a autoridade americana mais acatada em matéria de economia de serviços de utilidade pública" sobre o caso da Light. $O$ fío da argumentação ao descrever as experiências americanas conduz à defesa da constituição de Comissões de Serviços de Utilidade Pública. Estas comissões regulariam a qualidade do serviço oferecido, fixariam tarifas e garantiriam a estabilidade financeira. Para isto ele afirma ser necessário o acesso à contabilidade das empresas.

62 São dois artigos publicados no Boletim do Instituto de Engenharia "Regulamentação dos serviços de utilidade pública" no 59, abril 1930 e "Regulamentação dos serviços de utilidade pública" no 60, maio 1930 . 
No seu breve mandato como prefeito 63 de São Paulo Anhaia Mello concretiza muitas das idéias defendidas em seus artigos. Ele investe em diferentes campos. Através do Ato 127 ele introduz o zoneamento por usos na legislação urbanística paulistana que até aquele momento só regulava a relação entre alturas de edificações e largura de vias por zonas da cidade. As restrições de uso aplicavam-se apenas aos bairros estritamente residenciais da City que tinham bases contratuais. Logo que assume cria a Comissão de Serviços de Utilidade Pública 64 composta por funcionários municipais para fiscalizar e regulamentar os serviços públicos .Ressucita a lei 3008 de 1926 que permitia à municipalidade a cobrança do calçamento do proprietário e que havia sido revogada no ano seguinte. Conforme observa Campos Neto, ele é percebido como uma ameaça a interesses diversos - desde empresas estrangeiras como a Light até os proprietários de terrenos. Mas claramente é uma nova esfera de interesses que está se formando com a revolução de 30 .

Junto com a defesa da regulação e regulamentação das atividades imobiliárias e de serviços urbanos na cidade, Anhaia Mello escreverá sobre urbanismo e o governo da cidade. É também uma linha consistente de argumentação que terá efeitos importantes na constituição e no papel que desempenhará o setor de urbanismo na estrutura administrativa da prefeitura de São Paulo.

Mais uma vez o exemplo discutido é o americano. Ao descrever a experiência de governo das cidades americanas, Anhaia Mello estrutura o artigo no sentido de defender a criação de comissões - instâncias intermediárias que ele vê como imparciais, não partidárias, nem políticas. Ele propõe a organização das comissões para diversos fins. Articuladoras entre o executivo e o legislativo, sem compromisso direto com o eleitorado elas garantiriam, segundo ele, a defesa do interesse público. $O$ tom deste primeiro artigo de $1928^{65}$ pode ser avaliado por um dos sub-titulos: "city

63 Foram dois breves mandatos.o primeiro de 5 de dezembro de 1930 a 26 de julho de 1931 e depois por 20 dias de 14 de novembro a 3 de dezembro de 1931 .

64 Ato municipal $n^{\circ} 32$ de 27 de dezembro de 1930 apud Neto Campos, 1999, opus cit ,p442.

65 Mello, Luiz I gnácio de Anhaia "A cidade problema de governo" Boletim do Instituto de Engenharia ${ }^{\circ} 43$, dezembro de 1928. 
governement is business" As atividades de construção, calçamento, direção de serviços coletivos deveriam ser encaradas como negócios e para isto seria necessário um administrador - Commision manager.

Neste artigo é introduzida a idéia da City Plan Commission que ele sustentará por mais duas décadas e que será implementada na Prefeitura de São Paulo. Esta comissão do Plano da Cidade seria, na visão de Anhaia a "vestal incumbida de zelar pelo fogo sagrado do desenvolvimento futuro da cidade ". Esta entidade encarregada de produzir o master plan teria duas qualidades principais: a permanência e o não compromisso partidário.

Feldman alerta para a formulação acrítica de Anhaia Mello em relação à atuação destas comissões nos Estados Unidos. Citando um estudo de Topalov ela observa "uma das principais características do planejamento americano, no momento em que as comissões constituíram a forma privilegiada de elaboração de planos é a aliança entre os setores de negócios e jovens profissionais, particularmente os pertencentes ao American Institute of Planners " 66 A participação majoritária de homens de negócios da industria da construção de banqueiros e ausência da população de baixa renda imprimirá um caráter altamente conservador à atuação da maior parte das comissões sob o ponto de vista social e político 67 .

As observações de Anhaia Mello vem no momento de formação do setor de urbanismo na Prefeitura. A experiência de comissões já havia sido iniciada em 1925 e será retomada em 1937 com Prestes Maia na prefeitura da cidade. Nas duas vezes, porém, sem sucesso. $O$ fracasso na implantação destas comissões, que pressupunham a participação de outros setores da sociedade civil externos à administração municipal, pode ser atribuido à autonomização crescente deste setor. Campos Neto, já observava 68 esta tendência na década de 20 e percebia que as comissões poderiam

66 Feldman Sarah, "Planejamento e zoneamento : São Paulo, 1947 1972"tese de doutorado , 1996p 36

67 A autora cita o estudo de Robert Walker realizado entre 1937 e 1938 sobre a composição das associações americanas. opus cit , p 36.

68 Campos Neto, 1999,opus cit p 265 
ter cumprido um papel de costura de interesses divergentes.

A partir de meados da década de 40 a configuração do Departamento de Urbanismo assume forma mais definitiva. Abandonando a idéia de comissões desvinculadas da estrutura administrativa da prefeitura, Anhaia advoga a criação do departamento diretamente vinculado ao prefeito e fora da rotina administrativa . 69 "Se investigar, prever e planejar são funções 'staff' claro que é o urbanismo que deve estar diretamente subordinado ao prefeito e não pode ser uma simples divisão do departamento de Obras Municipais, que exerce funções de realização, de execução, funções 'linha' de acordo com a terminologia administrativa"70.

Também subordinada ao prefeito é proposta uma Comissão Consultiva do Plano da Cidade .Composta por cidadãos de reconhecida competência que exerceriam sem remuneração consultoria para a elaboração do plano. Crescentemente a idéia de plano irá se sobrepondo à de planejamento. Apenas com o engenheiro Carlos Lodi veremos que esta concepção se inverte.

Na reestruturação administrativa da prefeitura, em 1947, aparecem algumas das propostas de Anhaia como a criação simultânea, do Departamento de Urbanismo e da Comissão Orientadora do Plano da Cidade, dentro da Secretaria de Obras. Mas, ainda, sem a autonomia desejada 71

Por sugestão de Anhaia Mello acolhida pelo prefeito Janio Quadros, a Comissão passa a se chamar Comissão Orientadora do Plano Diretor do Município e teve seus

69 Ele já vinha desenvolvendo a idéia de um quarto poder e da separação entre funções 'staff' e 'linha' desde artigo publicado em 1937 . Retoma o mesmo tema na Revista Digesto Economico em 1947.

70 Mello, Luiz Ignácio de Anhaia "Urbanismo e Organização Administrativa"Revista Engenharia no 38 outubro de 1945 p 67.

71 com a seguinte composição: presidida pelo prefeito, quatro representantes do executivo, dois do legislativo, um do Instituto de Engenharia, um do IAB, um da sociedade Amigos da Cidade, um da Associação paulista de Imprensa, dois professores de urbanismo, um do Mackenzie e outro da USP e outros elementos que o prefeito julgar necessario.conforme Feldman, opus cit, $\mathrm{p} 41$. 
estatutos alterados no sentido de examinar todos os projetos relativos ao plano da cidade e não apenas quando solicitado. Passou também a articular esse plano com os municípios vizinhos no sentido de compor um plano regional.

Segundo Feldman o departamento resulta em um sistema híbrido entre staffe linha, mantendo atividades de rotina e o planejamento da cidade, estrutura que se manterá mesmo com a criação da COGEP ( Coordenadoria Geral de Planejamento )em 1972.

A diferença entre staffe linha é estratégica para se entender a desvinculação progressiva do planejamento urbano de outras esferas envolvidas na prática cotidiana da política municipal. Passa a ser um trabalho de gabinete de um pequeno grupo de tecnicos pertencentes aos quadros da carreira de funcionário público. Estes técnicos vão cada vez mais exercitar seu conhecimento técnico em propostas de legislação urbanística. É neste momento que no Departamento de Urbanismo da prefeitura são feitas as primeiras propostas para uma legislação de zoneamento para São Paulo.

Feldman observa também a importância política crescente que assume o zoneamento enquanto interferência concreta no mercado imobiliário. Na realidade, muito mais importante que a atividade de planejamento urbano que cada vez mais se restringe a estudos e propostas de caráter geral. Em um primeiro momento, pretende-se através da legislação de zoneamento uma proposta de organização da cidade. Com o tempo se autonomiza e passa a ser a esfera de negociação de uma política urbana.

A forma como concebe a organização territorial compõe uma outra e complexa faceta da produção intelectual de Anhaia Mello. Claramente ele a vincula à forma de organização social e política unindo pensadores tão diferentes como Patrick Geddes, Ebenezer Howard, Lewis Munford e Gaston Bardet. Para entender a articulação desta linhagem de pensamento urbanístico desenhada por Anhaia, um primeiro indício está na sua adesão a alguns dos princípios do modelo cidade jardim.

No conteúdo da disciplina de urbanismo que ministra desde 1927 já aparece a referência aos aspectos que considera importantes no modelo cidade jardim - a limitação da população, o cinturão rural , a industria e o sistema de propriedade 
individual, o exemplo é o das cidades jardim inglêsas Letchworth e Welwin.

Este conteúdo se expande para a experiência americana, inicialmente ${ }^{72}$ quando introduz a noção de unidade de vizinhança para definir os tamanhos de parques no planejamento local, mas se explicita quando descreve o subúrbio jardim de Radburn .

Na análise de Dal Co 73 sobre o significado da experiência de Radburn na história do urbanismo americano encontramos algumas pistas da filiação ideológica de Anhaia a esta linhagem de urbanismo.$O$ arquiteto e historiador italiano destaca Radburn como experiência de método e processos de planejamento elaborado pela Regional Planning Association of América RPAA e implementado pelo National Resource Planning Board.

Desde o início do século 74 se organizam associações reunindo profissionais que atuam e intervem nas cidades americanas. Estas associações crescem em número e tamanho denotam , por um lado, a forma de organização profissional e refletem a imbrincação entre a sociedade civil e o Estado no planejamento urbano americano.Um exemplo é a criação em 1917 da American Institute of Planners AIP para promover um forum de discussão aos profissionais de planejamento. Em 1934 ,é formada uma nova associação, a American Society of Planning Officials ASPO, para promover eficiencia na administração pública no planejamento local .Era aberta para membros: planning commissioners; ou outros planejadores que ocupassem qualquer posição em orgãos públicos 75 .Estas formas de associação profissional são citadas com frequencia por Anhaia Mello vistas como "conselhos de cidadãos dedicados ao estudo

72 Mello, Luiz Ignácio de Anhaia "O recreio activo e organizado das cidades modernas"Boletim do Instituto de Engenharia ,no 47, abril 1929

73 Dal Co Franceso "De los Parques a la region" in Ciucci Giorgio et alti La ciudad americana, Barcelona, Gustavo Gili , 1975

74. American Civic Association resultou da reunião, em 1904 , da American League for Civic Improvement (-formada em 1900 como National League of Improvements Associations ) com a American Park and Outdoor Art Association ,conforme Urban America : documenting the planners an exibition of the John M Olin Library oct 21-Dec 31 1985. Catalog compiled by Elaine D Engst $\mathrm{H}$ Thomas Hickerson.

75 Em 1978 AIP e ASPO se reunem e formam American Planning Association APA aberta para qualquer cidadão interessado em planejamento. -publicações: revista mensal Planning quinzenal newsletter APA News, quadrimensal Journal of the American Planning Association. 
desinteressado dos problemas urbanos" e que seriam incluídas no que denomina shema de organização municipal para 'urbanismo positivo' 76

A Regional Planning Association of America RPAA teve importante atuação nos anos vinte e início dos trinta, declinando lentamente durante o New Deal.Ela é completamente diferente de associações como a AIP em termos de uma posição ideológica que se concretizava em propostas urbanísticas Constitue-se em Nova York, em 1923 como um grupo informal reunindo arquitetos, planejadores, sociólogos e economistas 77 . Sua adesão, no mesmo ano, à International Garden Cities and Town Planning Federation sinaliza uma das filiações ideológicas da associação. $\mathrm{O}$ movimento milita em favor da realização de cidades jardim em uma perspectiva de desenvolvimento regional , propõe-se acompanhar o pensamento urbanístico inglês , em particular os trabalhos de Patrick Geddes e preparar planos em escala regional 78 . Segundo Dal Co, um aspecto interessante da associação está na discussão e divulgação de sua produção teórica 79 o que faz que mantenham contato com os principais expoentes do urbanismo moderno. Alem das relações evidentes com o movimento inglês pela cidade jardim ( participação conjuntas em congressos, visita a Letchworth, encontros com Howard e, Unwin ) mantém também contato com as experiências do urbanismo alemão, em especial de Martin Wagner e Ernest May. Mais labeis e mais tardias teriam sido o contato com as experiências russas. "Generalizando um pouco, a bagagem ideológica da RPPA pode fazer remontar as matrizes do pensamento vebleniano ou a Dewey, ainda que tendo em conta que neste tronco se insere a reativação da tradição regionalista europeia , francesa em particular

\footnotetext{
76 ele compara estas associações à recem criada Sociedade Amigos da Cidade .Mello, Luiz Ignácio de Anhaia "A Sociedade Amigos da Cidade e sua função no quadro urbano" Boletim do Instituto de Engenharia no 115, jun 1935

77 Conforme Dal Co , 1975 ,opus cit, p 257 , o primeiro documento que atesta a existência do grupo é um programa assinado por Clarence Stein para a constituição de uma Garden City and Regional Planning Association em março de 1923.O nome definitivo da associação e a formação de um comite executivo é decidido um mês depois.Entre os membros mais conhecidos do RPPA pelos urbanistas paulistas estão Clarence Stein, Lewis Munford. 78 Estes são alguns dos pontos elaborados no programa por Munford, Chase, Mc Kaye e Stein conforme Dal Co, opus cit , p 258.

79 a militancia nas questões urbanas em especial da habitação está expressa na produção teorica dos membros da RPPA.Infelizmente ,não coube nos limites deste trabalho incluir mais elementos sobre a trajetória de alguns destes profissionais.
} 
, a influencia da 'sociologia' de Geddes, alguns princípios da tradição 'descentralizadora' européia, desde Kropotkin a Howard. De tudo isto nasce uma síntese original composta , pragmática e idealista ao mesmo tempo, regida por um profundo compromisso civil e reformador que se atem precisamente aos valores da tradição reformista cuja urgência é continuamente adiada" 80 .

Um grande mérito da associação é colocar em debate propostas e realizações na construção de moradias de baixo custo Discutem os componentes do custo da habitação : a possibilidade de barateamento pela produção em escala , a formação de cooperativas, a necessária inclusão de áreas verdes nos projeto. As propostas procuram desenvolver metodologias para a construção de habitação.

Os dois exemplos mais significativos no campo da realização urbanística são: a construção do conjunto habitacional Sunnyside em 1925 e alguns anos mais tarde o empreendimento urbanístico Radburn .

Os responsáveis pelos dois projetos são Clarence Stein, Frederick Ackerman e H Wrigth. O primeiro é um projeto de 1202 moradias dispostas em blocos separados por espaços equipados com o objetivo de desenvolver uma vivencia comunitária. Procuraram elaborar tipologias que baiaxassem o custo sem perda de qualidade construtiva. Enquanto Sunnyside é a experiencia de um bairro, Radbum é a construção de uma cidade - da era do automóvel, segundo seus idealizadores. A solução urbanística hierarquisando a circulação viária ,separando a de passagem daquela que leva à habitação e termina em cul de sac remete às experiencias de cidade jardim inglesa, apesar de Stein 81 afirmar a filiação ao projeto de Olmsted para o Central Park.

Para Anhaia Mello a forma de organização do território parte da revitalização da vida em comunidade(a "neighborhood unit"), segundo ele geradora do sentimento e ação social e defende a cidade regional polinucleada, versus a metrópole mononucleada. 0

80 Dal Co, opus cit, p 262.

81 conforme Dal Co, p 272. 
formato de metrópole mononucleada é ultrapassado, e dará lugar as cidades regionais, aproveitando-se os recursos tecnológicos existentes e tomando sempre as necessidades do homem como medida. $O$ exemplo desta forma de planejamento é o plano do London County Council, considerado um exemplo a ser seguido, protegendo a "neighborhood life".

Uma abordagem mais específica e desenvolvida sobre o modelo cidade -jardim aparece, alguns anos mais tarde, no artigo "A Cidade Jardim" 82 , na Revista Digesto Econômico Conforme fora proposto originalmente por Ebenezer Howard em 1898 a unidade completa :residência ,trabalho, lazer "quem nela mora, nela trabalha"modelo que se difunde mais tarde para outras realidades e finalidades como as "green belts towns" projetadas e construidas pelas Resetlement Administration do governo Roosevelt.Anhaia destaca ao final do artigo o princípio fundamental da terra permanecer pública pois a valorização da transformação da terra de rural em urbana deve reverter para a comunidade e não ser apropriada individualmente.

A presença de Anhaia Mello continuará importante no periodo abordado no próximo capítulo.Através da sua atuação na universidade e junto aos órgãos públicos é possivel perceber as diferenças na constituição das três vertentes do urbanismo que se delineiam a partir dos anos cinquenta.

82 Revista Digesto Econômico - São Paulo - p.27-30, ,n .36 - vol.IX - nov/1947. 


\section{CAPÍtulo III}

\section{Três Vertentes do Urbanismo em SÄo PaUlo}

No final dos anos quarenta, três eventos sinalizam a definição de vertentes diferentes de urbanismo em São Paulo. O primeiro é a formação, em 1947, do Departamento de Urbanismo na Secretaria de Obras. A crescente institucionalização do planejamento urbano ${ }^{1}$ consolida, nos quadros da Prefeitura de São Paulo, o urbanismo vinculado à tradição da engenharia.

Em outra vertente, o Movimento Economia e Humanismo ,com a vinda do Padre Lebret, encontra um terreno fértil para a formação em urbanismo de jovens militantes católicos onde se combina um pensamento reformador, formulado a partir do conceito de solidariedade e o desenvolvimento de uma metodologia de pesquisa empirica vinculada à ação ${ }^{2}$.

Finalmente ,efetiva-se a separação do ensino da arquitetura da engenharia .Como resultado de um processo de autonomização que ocorreu no decorrer da década , a separação do ensino possibilitou a formação mais autônoma de um corpo de professores, recrutados entre aqueles que compunham os quadros do IAB, sintonizados com as idéias da arquitetura moderna.

Estas vertentes não são isoladas , pelo contrário, um exemplo é a presença importante, em todas elas, de Luiz Ignácio de Anhaia Mello. Como professor de urbanismo é um dos responsáveis pela formação da terceira geração de engenheiros civis e engenheiros arquitetos que atuam na Prefeitura de São Paulo. Nomeado primeiro diretor da Faculdade de Arquitetura e Urbanismo apoia a formação de um ensino de arquitetura mais vinculado ao movimento moderno, ao mesmo tempo que

1 Este Departamento é composto por seções cobrindo as diferentes etapas pretendidas para o planejamento urbano, da pesquisa à elaboração do plano.

2 Ver sobre a formação do movimento em São Paulo, Lamparelli, Celso "Joseph Louis Lebret e a pesquisa urbanos regional no Brasil- crônicas tardias ou história prematura" in Espaço \& Debates no $37,1994$. 
concebe junto ao ensino de urbanismo a organização de um centro de estudos e pesquisas ,o CPEU , para o desenvolvimento de planos urbanos. As experiências metodológicas desenvolvidas pelos escritórios da SAGMACS em São Paulo serão aplicadas nos planos elaborados pelo CPEU.

Na década de cinquenta os dois estudos contratados para São Paulo por equipes extemas à prefeitura têm conteúdo inteiramente diferente. Procuramos ao estuda-los identificar as principais propostas e analisa - las tendo como referência as formulações urbanísticas já elaboradas para São Paulo. Nos detemos não apenas na lógica intema propositiva de cada plano mas procuramos também analisar as causas da sua contratação tanto para a municipalidade como o significado deste documento na trajetória do escritório contratado.

Em 1950 é encomendado o "Programa de Melhoramentos Públicos para a Cidade de São Paulo" Trata-se de um estudo contratado pelo prefeito de São Paulo, Lineu Prestes ,à International Basic Economic Corporation, IBEC, sociedade comercial com sede em Nova York, dirigida por Nelson Rockefeller. O urbanista americano Robert Moses foi indicado como diretor de estudos, acompanhado de dez conselheiros americanos. Estudando a atuação do IBEC na América Latina constata-se em primeiro lugar que este plano é uma iniciativa isolada no conjunto de atividades desenvolvida pelo escritório americano. Em segundo lugar, percebe-se que este plano difere muito dos estudos de planejamento realizados até aquele momento para São Paulo. Tratavase de uma consultoria que ao realizar estudos técnicos abria a possibilidade de um mercado de atuação para empresas americanas.

A segunda pesquisa contratada, neste periodo, é a "Estrutura Urbana da Aglomeração Paulistana ( Estruturas atuais e estruturas racionais)", estudo elaborado pela SAGMACS Sociedade para análise gráfica e mecanográfica aplicadas aos complexos sociais e pela Comissão de Pesquisa urbana da Prefeitura de São Paulo. Iniciada em 1956, contratada pelo prefeito de São Paulo Wladimir de Toledo Piza é concluída na gestão de Adhemar de Barros, em 1958.

Este plano para a aglomeração paulistana abordava a nova realidade que se configura 
nesta época : a migração campo-cidade, o processo crescente de urbanização, o aumento da área urbana e consequente conurbação.

No urbanismo e no planejamento urbano e regional constatamos a imbricação, desde a gênese, entre a formulação do conhecimento e a prática profissional. Esta relação apresenta-se de forma diferenciada ao longo do tempo. Como observamos, no início ,os mesmos profissionais atuaram no ensino superior, na administração pública ou ainda sob contrato do Estado ou da prefeitura. A dupla inserção foi fundamental para a própria formação e legitimação da área .A partir dos anos 40 , quando se consolida como área de atuação profissional, ficam definidas carreiras com perfil bastante diferenciado.

Com a vinda do padre dominicano francês, Louis Joseph Lebret, ao Brasil em 1947, para difundir o movimento Economia e Humanismo e a formação dos escritórios regionais da SAGMACS em Recife e São Paulo abre-se uma nova possibilidade de inserção e expectativa de resultados do trabalho profissional .Para os arquitetos, engenheiros, sociólogos, economistas que compõem os escritórios da SAGMACS esta dupla inserção traz tensão e ambiguidade, em especial porque se colocam expectativas de transformação social através do trabalho profissional Este profissional engajado vai participar de escritórios de consultoria e ingressar no ensino na universidade. Somente nos meados da década de setenta passam a participar de equipes em órgãos da prefeitura.

A comparação entre os três momentos de contato com as idéias de urbanistas franceses no Brasil- no início do século,com Joseph Antoine Bouvard ;nos anos vinte e trinta, através dos planos dos arquitetos ligados a Société Française d' Urbanisme e após a segunda guerra mundial no contato com o Movimento Economia e Humanismo revela formas diferentes de penetração no meio técnico urbanístico local. Para entender estas diferenças procuramos estudar as lógicas internas das transferências.

Analisamos em seguida a forma como se estruturam as idéias e a ação dos engenheiros municipais no Departamento de Urbanismo durante este período, em particular a atuação da Comissão do Plano Diretor da cidade. $O$ relato de Carlos 
Brasil Lodi, já nos anos sessenta ,mostra como as contribuições externas foram absorvidas, criticadas ou apenas recusadas

\section{IBEC e o plano de melhoramentos para São Paulo}

O plano de melhoramentos elaborado em seis meses pelo IBEC sob a coordenação do urbanista americano Robert Moses foi objeto de polêmica no meio técnico e político paulistano desde o momento de sua contratação. Tratava-se na realidade, como firma o contrato ,de um relatório detalhado para o planejamento de obras da prefeitura.

Sob o ponto de vista urbanístico pode ser considerado em uma linha de continuidade com o Plano de Avenidas ,elaborado por Francisco Prestes Maia em 1930 ,ao enfatizar mais uma vez como solução para São Paulo o transporte sobre pneus em um sistema de vias expressas. Projetadas em trincheira atualizam para os anos cinquenta os projetos em escala mais modesta elaborados por Prestes Maia. O modelo de organização espacial é porem outro .O esquema teórico radial perimetral do Plano de Avenidas é substituído por um sistema radial limitado pelas avenidas marginais e completado por penetrações das estradas até o centro da cidade .Mantém -se apenas o sistema em Y cortando o centro da cidade.

Duas questões abordadas no Plano: a indicação de compra de ônibus para suprir o transporte coletivo da cidade e a proposta de formação de uma corporação com a participação da Light Tramway and Power para urbanizar as terras ao longo do canal do Rio Pinheiros, revelam que não se tratava apenas de um plano urbanístico, mas que abria a possibilidade de um campo de negócios entre as empresas estrangeiras e a municipalidade.

O IBEC já atuava no Brasil há alguns anos e havia feito um trabalho de consultoria para a Light sobre a utilização das áreas remanescentes do rio Pinheiros. Entre as atividades desenvolvidas pela corporação tanto a consultoria para a Light como o plano elaborado para a Prefeitura de São Paulo foram pouco importantes não merecendo nem uma menção no estudo de caso realizado por Wayne Broehl em 
$1968^{3}$

A formação do IBEC revela o interesse que o Brasil representa como mercado potencial para empresas americanas. Este mercado segundo os negócios intermediados pelo IBEC são bastante dirigidos e inovadores :no setor de implementos agrícolas, produção de sementes, adubos, maquinas ;no setor agro industrial ,café solúvel e leite em pó; no setor financeiro pela criação de fundos mútuos; no setor de abastecimento a organização do comercio varejista através da implantação de supermercados.

A leitura dos contratos e da correspondência entre as partes interessadas revela 0 IBEC funcionando, também, como um canal de informação sobre a esfera politica e técnica local. Um exemplo são as informações que circulam sobre a probidade administrativa de Adhemar de Barros

As forma de atuação através de contratos para a intermediação de interesses entre empresas brasileiras, empresas americanas e órgãos públicos revelam uma nova lógica de atuação expondo e explicitando a arena de interesses econômicos .

\section{IBEC : constituição e forma de atuação}

A origem do IBEC situa-se no pós guerra como parte de uma política de desenvolvimento econômico na América Latina empreendida pelo empresário americano Nelson Rockefeller. Tendo como objetivo "o desenvolvimento industrial e a elevação do padrão de vida da população" dos países ele funda, em 1945, a empresa American International Association for Economic and Social Development (AIA).Sem fins lucrativos ela seria formada por capitais americanos e latino americanos. A nova companhia começa a atuar no Brasil pelo setor de sementes.

\footnotetext{
3 Nos baseamos no estudo de Broehl, Wayne G. "United States Business Performance Abroad : the case study of International Basic Economy Corporation"1968, National Planning Association.Este estudo como esclarece na folha de rosto é o $13^{\circ}$ estudo da National Planning Association sobre a perfomance de empresas americanas no exterior.As informações foram complementadas por pesquisa realizada em novembro de 97 nos Arquivos da Rockefeller Foundation quando encontramos as referncias ao contrato de São Paulo.
} 
IBEC - Brazil Operations, late 1954 Fonte de Broehl, Wayne G. United States Business Performance Abroad : the case study of International Basic Economy Corporation. National Planning Association, 1968.

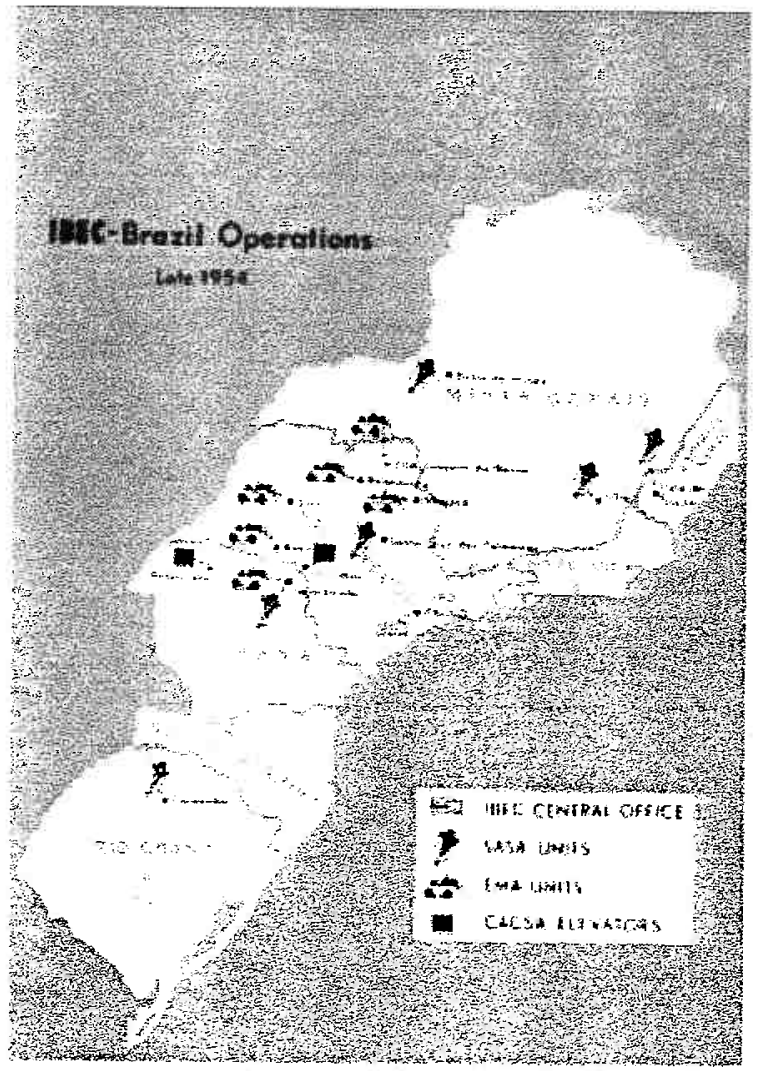

Com o sucesso e o desenvolvimento das atividades é proposta a associação com uma companhia brasileira .Logo evidencia-se a impossibilidade de ser ao mesmo tempo uma organização filantrópica e uma companhia comercial visando lucros. A impossibilidade faz criar uma nova organização, esta sim para fins lucrativos, o IBEC.

O IBEC nasce, portanto, com o objetivo de apoiar o desenvolvimento de empresas associadas americanas e latino americanas. Um dos objetivos chave do IBEC era o de obter lucros .Os fundadores acreditavam que outras empresas privadas, no mundo em desenvolvimento, poderiam ser persuadidas a seguir o exemplo e o efeito multiplicador do IBEC seria sentido.

Fundada em $1947^{4}$, começa as atividades no Brasil e na Venezuela. Em duas décadas ${ }^{5}$

\footnotetext{
${ }_{5}^{4}$ Broehl, W, opus cit, p XVI

5 Este livro foi publicado em 68 e o período coberto pelo estudo termina em 67. Nos arquivos da RFA encontrei informação de funcionamento do IBEC até 1974.
} 
fundou 200 empresas em 33 diferentes países atuando em áreas como supermercados, agricultura, industrialização de derivados do leite, fundos mútuos, habitação para classe média, pecuária e manufatura.

Na primeira fase, no Brasil, o IBEC ${ }^{6}$ escolheu um enfoque extensivo para enfrentar o problema da alimentação. Entre as diferentes atividades a companhia proveu serviços especializados para o fazendeiro aumentar a produção. Quatro companhias foram organizadas : uma na produção de sementes, outra em empreendimentos associados de agro pecuária , a terceira em transporte,em associação com a Standard Oil e a quarta companhia investindo na compra de terras. Apenas uma empresa atuava ligada a American International Association for Economic and Social Development (AIA) em um programa na área de nutrição.

\section{O IBEC e a Light atuando em São Paulo.}

Em assuntos urbanos temos a primeira noticia de atuação,em janeiro de 1950 Portanto seis meses antes do contrato com a Prefeitura de São Paulo para elaborar o Plano de Melhoramentos, o IBEC Technical Services Corporation, escritório técnico do IBEC já está atuando em São Paulo conforme o demonstra o memorandum assinado por Robert Moses ${ }^{7}$ dirigido a Nelson Rockefeller .Neste documento ele relata o acordo estabelecido com a São Paulo Tramway Light and Power para uma consultoria sobre a recuperação e o aproveitamento das terras adjacentes ao canal do rio Pinheiros da confluência com o rio Tietê até a barragem no Rio Grande .

O contrato da Light com o governo do Estado para a construção do sistema de energia previa que colocasse a disposição todo o excesso de terra dentro dos limites da várzea após ter completado o trabalho de aprofundamento e alargamento do canal com a finalidade de controle de enchentes e provimento de energia.

\footnotetext{
${ }^{6}$ Conforme memorandum de Kenneth Kadow, no Rio de Janeiro para Morrison Tucker IBEC Nova York, 24 abril de 1947, Folder IBEC Brazil Progress 1947, box 12, AIA IBEC series, RG 4 (NAR Personal), Rockefeller Family Archives, RAC.

7 A letter agreement entre o IBEC e a Light datava de 3 de agosto de 1949 segundo Memorandum de Robert Moses dirigido a Nelson Rockefeller , 20 janeiro, 1950, Folder IBEC Technical services, box 5, AIA IBEC series, RG 4 (NAR Personal), Rockefeller Family Archives, RAC.
} 
Para abertura do canal seriam necessários de oito a dez mil acres de terra dos quais ,dois mil foram adquiridos pela Light, mil estariam sendo utilizados pela Light em contrato sujeito a devolução aos antigos proprietários após pagamento dos custos das melhorias realizadas e 150 foram depois adquiridos pela companhia sujeito a certos direitos dos antigos proprietários. A Light ainda comprou 110 para seu uso. $\mathbf{O}$ restante era propriedade pública e privada sem vinculo com a companhia canadense.

Moses elogia a contratação do IBEC Technical Services pela Light que poderia ter seguido o contrato e devolvido as terras não utilizadas após a abertura do canal sem nenhum plano de utilização. Isto porem, alerta Moses, poderia ter graves conseqüências ao interesse público levando a especulação imobiliária e parcelamentos sem uma visão de desenvolvimento urbano.

Seriam terras, Moses observa, com grande potencial para industria, escritórios, habitação, lazer e outras finalidades públicas e privadas .Qualquer plano para esta área precisaria incluir a eliminação do esgoto que corre do Tietê para o Pinheiros ${ }^{8}$.

O trabalho do IBEC seria traçar um plano de ocupação da área Ele já avança algumas propostas de uso na área próxima ao Jockey Club para uma área continua de no mínimo duas milhas de parques públicos ou clubes de esportes ${ }^{9}$.

Discorre sobre a questão da necessidade de um zoneamento ${ }^{10} \mathrm{e}$ os custos estimados que incluíam : a compra de terra (de US\$80 a 100 milhões), a dragagem e disposição das terras para a abertura do canal(US\$ 4 milhões), o custo de ferrovia, avenidas expressas, pontes e outros melhoramentos (US\$ 10 a 12 milhões).

Para realizar estes trabalhos Moses afirma que a companhia canadense e outros

\footnotetext{
8 Observa ainda Moses que uma estimativa do custo para a instalação de um sistema de esgotos havia sido feita, sob demanda da prefeitura de São Paulo, pela firma Metcalf e Eddy de Boston.

9 ele identifica estes clubes como parques semi públicos.

10 Oberva que existe hoje um zoneamento e uma legislação de edificações muito rudimentar e a regulamentação de uso nas terras ao longo de canal do Pinheiros poderia servir como um modelo de codigo para a cidade
} 
interessados estavam contemplando a possibilidade de organizar uma empresa que adquiriria os direitos de ex - proprietários e proprietários para poder viabilizar o planejamento e desenvolvimento da área ao longo do canal. Esta proposta articula a consultoria para a Light e o plano de Melhoramentos para a Prefeitura de São Paulo, como veremos em seguida.

\subsection{Plano de Melhoramentos para São Paulo}

Em 14 de julho de 1950 é firmado o contrato ${ }^{11}$ entre a prefeitura de São Paulo, representada pelo prefeito Lineu Prestes, e o IBEC para a realização dos seguintes estudos: um mapa geral e um zoneamento; sistema de vias expressas; um sistema de transporte de massa; sistema de parques ; canalização do rio Tietê e aproveitamento das terras a margem do rio, engenharia sanitária e sugestões quanto aos métodos de financiamento para execução das obras públicas e serviços.

O relatório deveria estar pronto e impresso, em seis meses. $O$ contrato especificava ainda a quantia a ser paga pela prefeitura ${ }^{12}$, Em outubro uma carta da IBEC Technical Services Corporation ao IBEC acertava as formas de prestação de serviços, inclusive mencionava a contratação dos serviços de Robert Moses e Frederic Collins para a supervisão e direção dos serviços ${ }^{13}$

O relatório encaminhado por Moses ${ }^{14}$ acrescentava dois objetivos aos definidos em contrato : por iniciativa da equipe americana o plano de beneficiamento e urbanização

\footnotetext{
11 Translation of contract for the engaging of technical services. Folder IBEC Technical services, box 5, RG 13 Public Relations ), Rockefeller Family Archives ,RAC.

12 Seriam pagas seis parcelas de US $\$ 15.000 .00$ para as despesas de custeio da equipe.O total não deveria exceder $\mathrm{Cr} \$ 2.000 .000,00$ que fora o credito aprovado para o contrato.Entretanto ,se não fosse suficiente a prefeitura se comprometia a solicitar a Camara recursos suplementares.Após a entrega do relatório seria pago $\operatorname{Cr} \$ 400.000,00$. in Translation of contract for the engaging of technical services. Folder IBEC Technical services, box 5, RG 13 Public Relations ), Rockefeller Family Archives , RAC

13 Carta de ITSC para IBEC datada de outubro 1950.Folder IBEC Technical services, box 5. RG 13 Public Relations), Rockefeller Family Archives, RAC.

14 "Programa de Melhoramentos Públicos para a cidade de São Paulo . Program of Public improvements "IBEC, Robert Moses, diretor de estudos, New York City , novembro 1950
} 


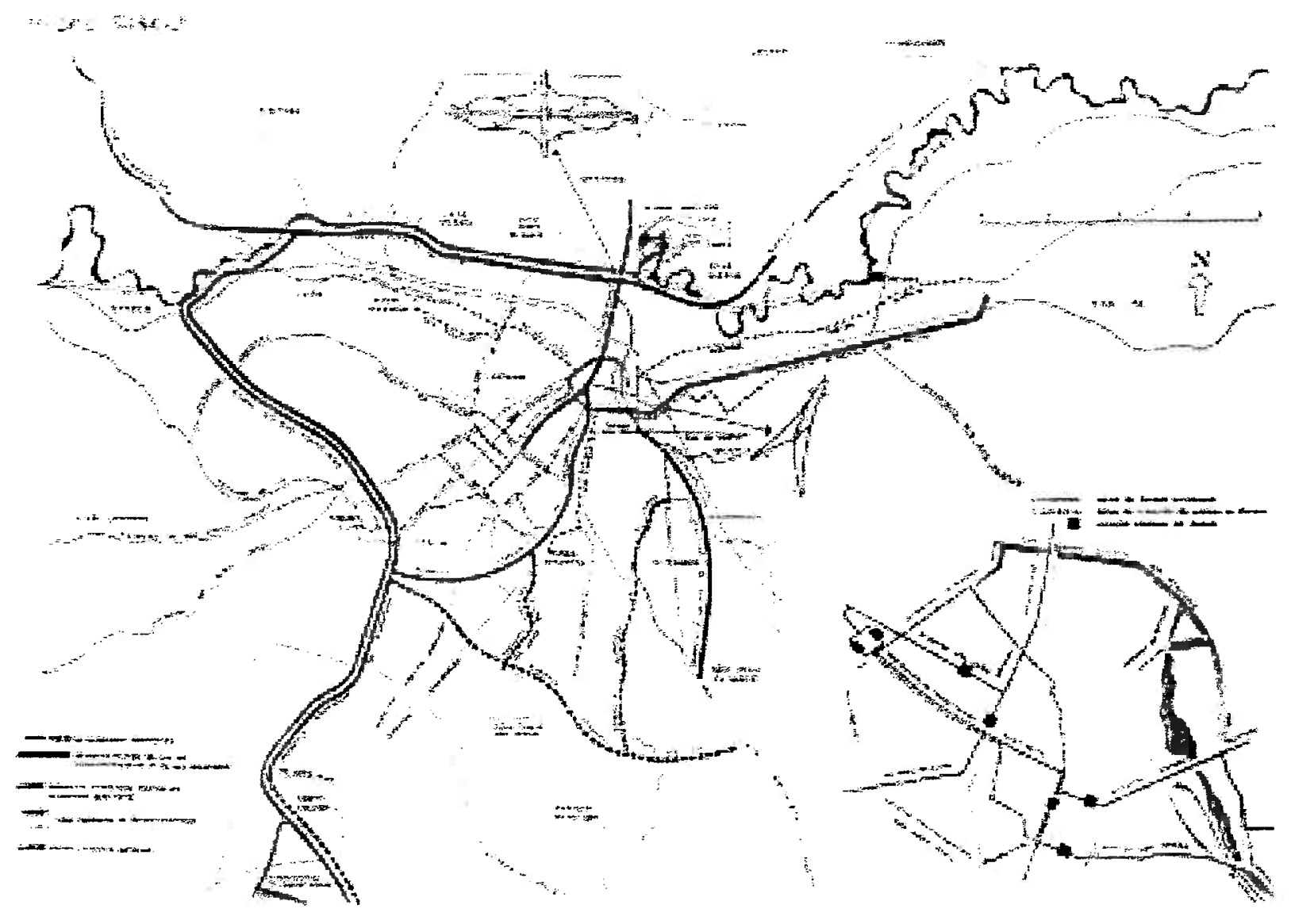

Sistema de Avenidas .Fonte: International Basic Economic Corporation Programa de Melhoramentos Públicos para a cidade de São Paulo . Program of Public improvements IBEC, New York City . novembro 1950

do canal de Pinheiros e a pedido do prefeito de São Paulo, o problema de eliminação de resíduos sólidos.

Quatro engenheiros municipais foram convidados a visitar obras em Nova York aprofundando as relações entre a Prefeitura e o IBEC ${ }^{15}$. $O$ relatório iniciava recomendando a realização de um levantamento aéreo fotogramétrico das áreas urbanizadas em escala 1:2000, com base neste levantamento deveria ser feita a planta oficial da cidade.

15 Luis Carlos Berrini do Departamento de Urbanismo ; Mario Lopes Leão do Departamento de Serviços Municipais; Paulo Sampaio Witaker do Departamento de Obras Públicas e José C Borroul do Departamento de Obras Publicas . 
A equipe de consultores elaborou uma proposta de zoneamento. Esta proposta não difere do que já vinha sendo elaborado na prefeitura de São Paulo - a definição de zonas de usos de forma a resguardar direitos de propriedade ${ }^{16}$. Definiram nove categorias de uso (industrial, comercial e residencial )que se combinam em zonas segundo um modelo de organização espacial em círculos concêntricos .

$\mathrm{Na}$ área central uma zona de comercio, serviços e industrias leves. No entorno imediato a esta área central seriam permitidas industrias leves e armazéns .Ao longo do Tietê , perto da divisa leste da cidade e nas vizinhanças do Canal do Pinheiros eram indicadas como zonas industriais e no resto da área urbana residências. Sugeriam que a elaboração do decreto de zoneamento deveria tomar como base e apoio o zoneamento de Nova York, para isso encaminhavam cópia da legislação da cidade.

Consideravam urgente resolver o problema do transporte coletivo na cidade e propunham a substituição da frota de ônibus e bondes em uso em São Paulo por nada menos do que a compra imediata de 500 ônibus novos, grandes e espaçosos.

Completando a frota seria necessário ainda a aquisição anual de 100 ônibus, durante dez anos. Com motor a diesel, de fabricação estrangeira poderiam ser montados no Brasil. Incluiam também recomendações quanto a ofícinas e itinerários dos ônibus com modificações no sistema viário.

Um ponto importante do relatório era a proposta do sistema de vias expressas ${ }^{17} \mathrm{e}$ rotas de ônibus com estimativas do custo dos terrenos a serem desapropriados e custos da construção do sistema. Um novo traçado para a Avenida do Anhangabaú corta o parque do Ibirapuera, mas repete com a avenida 9 de Julho o esquema em Y do Plano de Avenidas. A novidade maior está na articulação das rodovias para o Rio de Janeiro e a Via Anhanguera formando a rodovia expressa do Tietê. A rodovia Anchieta

16 "entende-se por zoneamento uma serie de regras acerca do uso das areas da cidade de tal modo que se protejam da melhor forma tanto os interesses da coletividade como os do proprietário individual"p 23

17 Rodovias expressas propostas:Avenida Anhangabaú, 9 de Julho, Rodovia expressa do Anhangabau , Rodovia expressa do aeroporto, Rodovia expressa do Sul, Rodovia expressa da Água Funda, Rodovia expressa da Penha, Rodovia expressa Anchieta Rodovia expressa Tiete do Pinheiros 
penetra até o centro cortando o Ipiranga em via expressa. Na zona leste, paralela a avenida Celso Garcia, apenas uma nova rodovia expressa , mantendo a desigualdade de propostas de intervenção entre as áreas da cidade. A diferença de tratamento é visivel entre os quadrantes da cidade ao se observar o número e a articulação do sistema de avenidas existente e proposto no quadrante oeste e sudoeste .

Na proposta de formação de uma companhia para a urbanização das terras do canal do Pinheiros a São Paulo Tramway Light and Power teria um papel central. Conforme se observou anteriormente ela estava encarregada dos trabalhos de dragagem do rio e para isso dispunha e havia adquirido terras que seriam devolvidas a municipalidade e aos antigos proprietários quando concluídos os serviços de abertura do canal.

No plano para a prefeitura ,Moses completa o trabalho de consultoria realizado para a Light e propõe que a nova companhia seria proprietária e responsável pelo

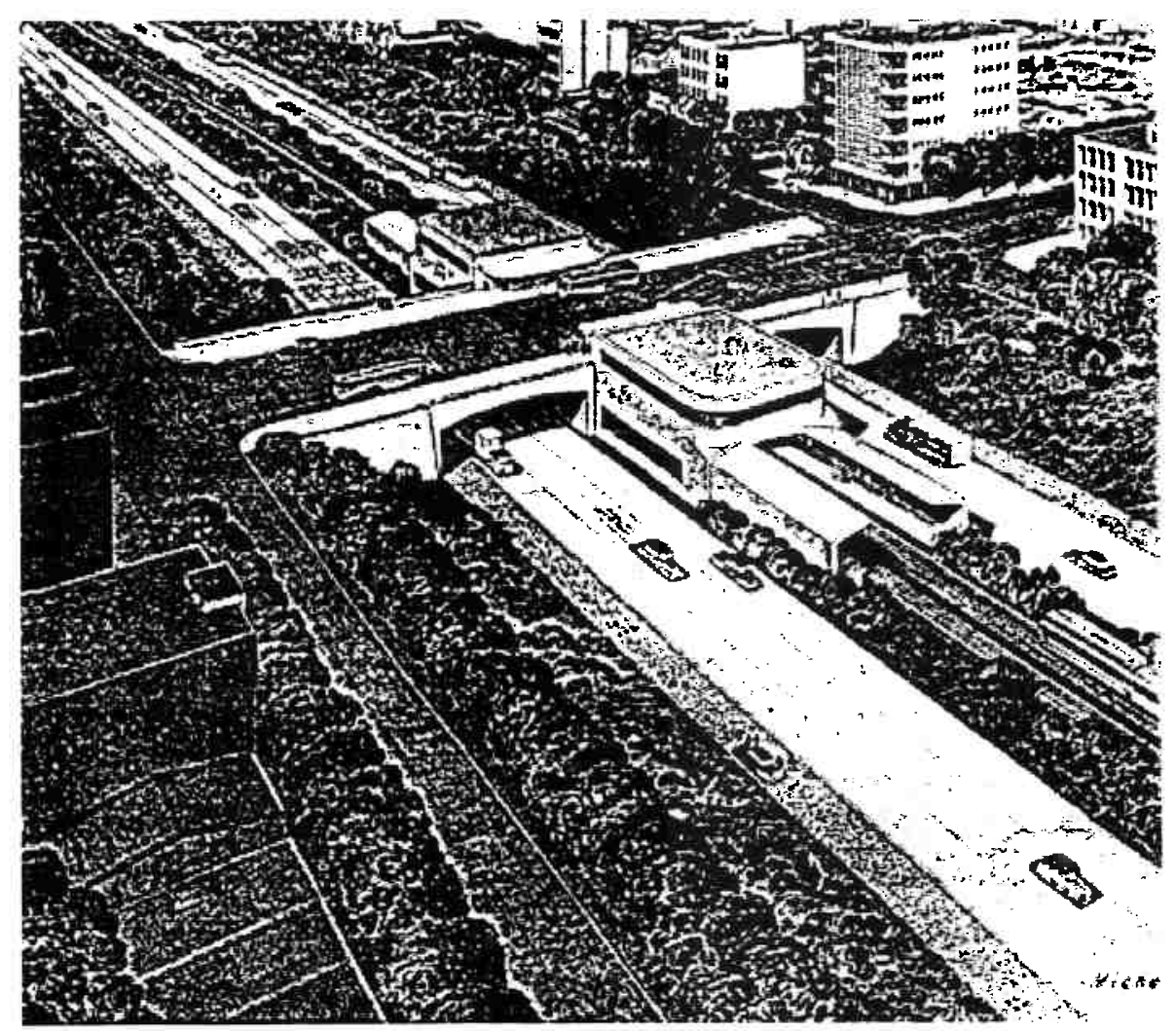

Rodovia expressa : International Basic Economic Corporation Programa de Melhoramentos Públicos para a cidade de São Paulo . Program of Public improvements IBEC, New York City, novembro 1950 
desenvolvimento de atividades ao longo do canal. A municipalidade passaria a ter apenas o direito de passagem para a construção de rodovias, estradas de ferro, pontes, linhas de transmissão e outros serviços públicos. ${ }^{18}$

Os consultores americanos sugeriam também a passagem do controle do trânsito, do âmbito do Estado para o do Município. Esta questão da divisão de atribuições e falta de coordenação entre estado e município é abordada por Moses também no referente ao abastecimento de água, rede de esgoto e coleta de lixo.

Recomendações específicas são feitas quanto à necessidade de estação de tratamento e extensão da rede .Quanto ao lixo, faż-se menção a necessidade de mecanização da coleta, programa de aterros sanitários e construção de incineradores. Para o financiamento estudou-se a necessidade de aumentar o endividamento da Prefeitura através do lançamento de títulos municipais.

\section{Avenidas , parkways, express ways}

Da tradição do movimento city beautiful, como observamos nos capitulos anteriores, as primeiras referências para o urbanismo paulistano são as proposições de desenho de sistema de ruas. Em 1911 já aparece no texto de Victor da Silva Freire uma citação aos trabalhos de Charles Mulford Robinson, ao se referir à proposta de reformulação do sistema viário na área central da cidadé.

Na proposta do Plano de Avenidas de Prestes Maia em 1930 o projeto do desenho das avenidas marginais ao rio Tiête apoiava- se na tradição americana de parkwaysavenidas que ligassem os parques propostos para a cidade

Esta idéia é uma das mais importante contribuições de Frederick Law Olmsted .Ele ampliou do desenho de um único mesmo que multifuncional parque, como o Central Park em Nova York, para o planejamento de um sistema de parques e boulevards. As primeiras avenidas de traçado sinuoso em verdadeiros parques urbanos evoluíram para

18 cönforme p 61 dò relatorío. 
sistemas mais complexos com elementos mais variados

As primeiras avenidas traçadas por Robert Moses em Nova York - Northern State Parkwaye Grand Central Parkway -são claramente inspiradas neste desenho de avenidas parques. Foram obras realizadas na década de vinte, antes da quebra da

Seção mínima de artéria central de la classe. Fonte: Maia, Francisco Prestes Estudo de um Plano de Avenidas para São Paulo São Paulo, Melhoramentos.

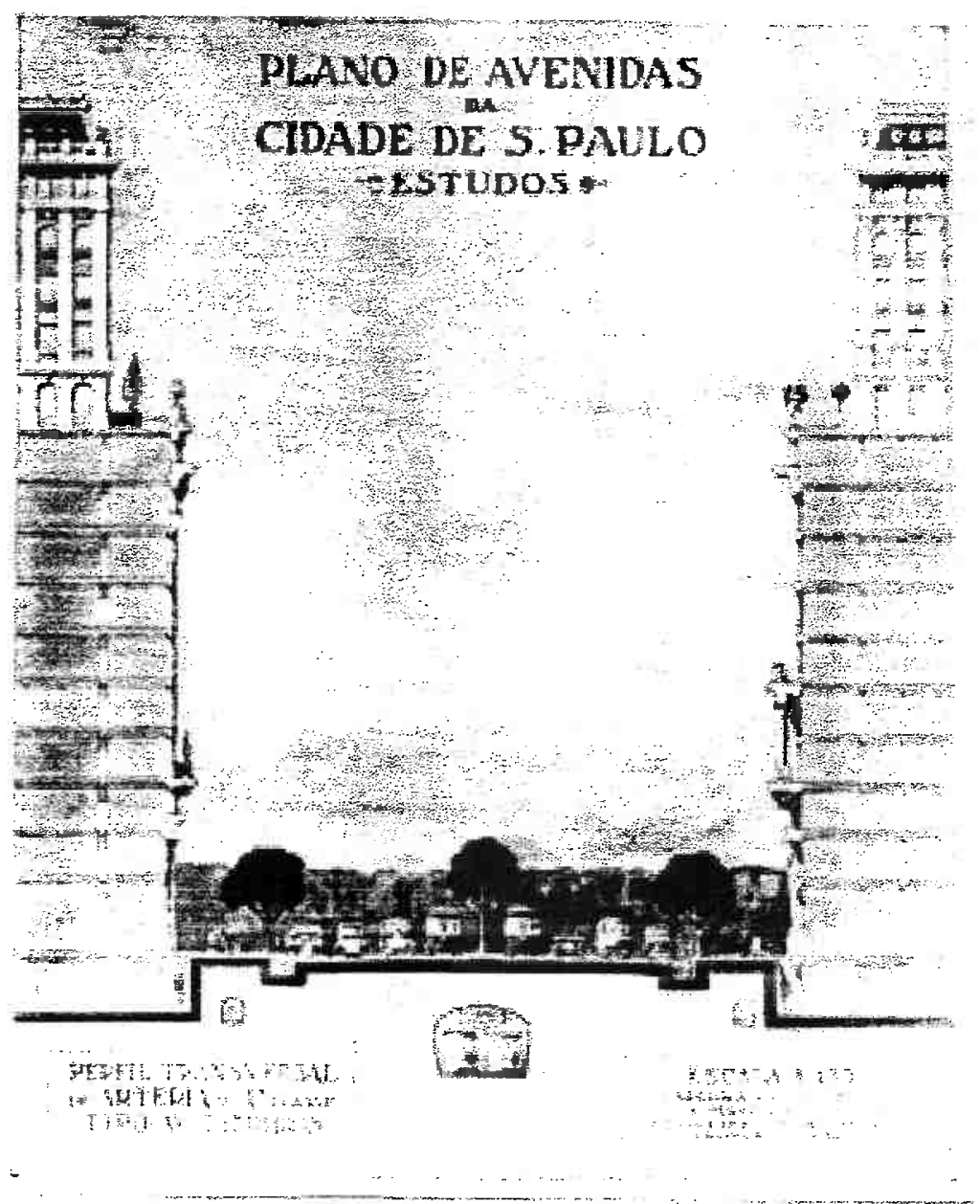
1930

\footnotetext{
${ }^{19}$ Uñà segunda contríbuição importante de Olmsted fơi a noção de que parques e mais

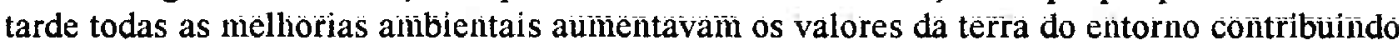
para a valorização dos eimpreendimentoos privados e retornando aos cofres públícos ätrảvés do aumento do valor dos impostos.

A terceira contribuição importante foi a prática de consultor que ele estabelecia com as elites economicas e culturais de uma cidade que haviam contratado seu trabalho e que acabavam por se encaminhar para o desenvolvímento de umim planö e pagamento dos serviços.
} 
Bolsa de Nova York, quando a sociedade americana vivia os anos dourados de expansão das atividades de lazer.

O parque estadual de Jones Beach, em Long Island foi construído por Moses, sobre terrenos pantanosos, em dois anos e as avenidas arborizadas que unem o Queens a Jones Beach tem o suave traçado desta relação artificialmente criada entre a natureza è a obràa viấrià.

Na mesma época em São Paulo, o traçado para as avenidas marginais ao rio Tietê proposto inicialmente por Saturnino de Brito, desenvolvido por Ulhôa Cintra e acatado por Prestes Maia no Plano de Avenidas é feito na melhor tradição das parkways ,traçadas

no meio de pequenas áreas arborizadas que uniriam os parques propostos para a cidade.

Moses defende a idéia do subúrbio "conectado "á cidade por grandes avenidas permitindo as duas possibilidades de cotidiano - viver na grande cidade e o fim de semana no campo e viver em uma grande casa no campo e manter na cidade um pequeno apartamento. Defende principalmente as qualidades -os estímulos culturais próprios às metrópoles. $\mathrm{Na}$ nova versão das parkways $=$ as vias expressas tem como melhor exemplo a construção por Moses nos anos cinquenta da Cross- Bronx.. No relato de Marshal Berman percebemos o impacto que representou a passagem a "golpes de cutelo" da nova avenida e a destruição de todas as suas referencias urbanas do seu bairro, o Bronx.

Como acontecera em Nova York, na década de cinquenta, em São Paulo deixava-se de lado o traçado bucólico das avenidas parques e atualizava-se o plano de avenidas de Prestes Maia em um plano de avenidas expressas .Este novo padrão de circulação viária será implantado na cidade nos anos sessenta.A avenida 23 de maio é a que melhor corresponde ao traçado proposto por Moses.

A acolhida e mesmo as críticas de Prestes Maia ao Programa de Melhoramentos Publicos de Moses sinalizam a filiação do urbanista a uuma mesma tradição de 
urbanismo de realizações, de obras .Distanciando-se de qualquer preocupação teórica , irônico quanto ao potencial transformador das utopias tanto a modemista como a filiação ao modelo cidade jardim, Prestes Maia mais uma vez aproveita a oportunidade para demonstrar ser profundo conhecedor da estrutura fisica da cidade, sabendo cada detalhe do sistema viário, e do funcionamento da infraestrutura de água ,esgoto, drenagem .Nas críticas ao relatório Moses reafirma soluções propostas no Plano de Avenidas ,como a localização da ferrovia ao longo da margem do rio Tietê.

Prestes Maia é o único a demonstrar conhecer em parte a extensão das atividades do IBEC no Brasil ${ }^{20}$, sem desvendar entretanto as razões da escolha da consultoria externa.

Como já o fizera em 1930 , no Plano de Avenidas, ao criticar os especialistas curiosos de passagem , mais contundente porém, declara o relatório americano de pré - técnico , apenas com recomendações gerais, quando os urbanistas paulistas como Victor Freire, Ulhôa Cintra e ele mesmo já haviam passado do terreno das idéias a realizações práticas.

No terreno das recomendações o relatório nada acrescentara , segundo ele "só confirmaram o que já estava diagnosticado, resolvido ou em execução."

Como não atentar para as observações sobre os embates de Moses com a corrente modernista de urbanismo nos Estados Unidos ${ }^{21}$. Irônico ,Prestes Maia , observa que aqueles que aguardavam "perspectivas fantásticas, espaços verdes, imensos arranha céus a Corbusier e paisagismos a inglesa" esqueciam que Moses, e nas entrelinhas pode se ler- como ele, era da escola realista de urbanismo: "realiza e não oferece a

20 "Absurdo inicial foi a maneira de promover a consulta, se consulta foi, através de uma organização muito idônea, mas predominantemente comercial e agrícola que tanto importa maquinaria para a lavoura, sementes, adubos, e reprodutores, como tecnicos e urbanistas para cá trazidos sem se saber bem porque nem para que"Maia Francisco Prestes , $O$ Programa Norte Americano de Melhoramentos para São Paulo"in Revista Digesto Economico, abril , 1951 pp 5-27

21 "eriçam - nos os cabelos ao pensar os nomes com quem tem brigado : Sarinem, Gropius, Mendelsohn, Lloyd Wright, Munford" Maia Francisco Prestes, 1951, opus cit , p 7 
incoerência de urbanistas que passam a vida a pregar utopias e morrem sem deixar o mais pífio arruamento".

Em janeiro Adhemar de Barros, governador de São Paulo e Lineu Prestes apresentaram ao público o plano recebido ${ }^{22}$. Imediatamente muitas críticas ${ }^{23}$ foram feitas e publicadas na grande imprensa e nas revistas especializadas. A principal, segundo correspondência enviada pela IBEC para Nova York, veio do IAB, seção São Paulo.

O IAB esclarece ter recomendado enfaticamente a realização de um plano para São Paulo. Não considera que o relatório elaborado pelos especialistas estrangeiros substituíssem o tão reclamado plano geral, não seria "satisfatório nem como simples programa de melhoramentos porque a despeito de ter sido feito por nossos especialistas que compreendem os problemas locais é absolutamente impraticável porque contem erros elementares resultado do fato de seus autores não nos conhecerem não conhecerem nossa cidade e não terem nem o mais superficial contato como eles declaram" 24 .

As críticas do IAB dão a tônica para os outros comentários críticos como o de Leo Ribeiro de Moraes em reunião da Sociedade Amigos da Cidade ${ }^{25}$. Aparecem algumas observações mais favoráveis. Neste segundo caso, publicadas pelo Diario de São Paulo de Assiz Chateaubriand , as observações vieram do engenheiro Henrique Neves

22 Correspondencia de Henry Bagley para Francis Jamieson em 15 dezembro de 1950 relatando a apresentação ao público e à imprensa do plano elaborado pelo IBEC. Folder IBEC Technical services, box 5, RG 13 Public Relations ), Rockefeller Family Archives ,RAC

${ }^{23}$ Nota-se que as critícas da imprensa eram acompanhadas e comentadas desde as mais gerais ao plano até os comentários de Carlos Lacerda, criticando comunistas e reproduzindo as críticas pessoais à Nelson Rockefeller. Correspondencia de Henry Bagley para Francis Jamieson em 21 dezembro de 1950 Folder IBEC Technical services, box 5, RG 13 Public Relations ), Rockefeller Family Archives , RAC

24 correspondencia de Henry Bagley a Francis Jameson de 26/01/1951 Folder IBEC Technical services, box 5, RG 13 Public Relations), Rockefeller Family Archives, RAC 25 Correspondencia de Henry Bagley para Francis Jamieson em 30/01/1950 de 1950 Folder IBEC Technical services, box 5, RG 13 Public Relations ), Rockefeller Family Archives ,RAC 
Lefevre e de Ranulpho Pinheiro Lima, editor da revista Engenharia do Instituto de Engenharia ${ }^{26}$.

Logo após a entrega do relatório, iniciaram-se as negociações do prefeito Lineu Prestes para obter o financiamento para realizá-lo. ${ }^{27}$

Em fevereiro é eleito Lucas Garcez para o governo de São Paulo e ele nomeia Armando Arruda Pereira para a prefeitura. Na troca de correspondência entre Henrique Villares e Moses imediatamente é encaminhado um curriculum muito elogioso do novo prefeito, salientando o mestrado na New York University e a sua ligação com o Rotary Club. Apesar de aparentemente muito mais afinado com o meio técnico e político americano as negociações para o financiamento do plano não são mais noticiadas. ${ }^{28}$

\section{O Padre Lebret e a formação do Movimento Economia e Humanismo}

O Movimento Economia e Humanismo é formado no periodo da guerra por Joseph Lebret. Nascido na Bretanha era oficial da Marinha Nacional quando entra para a ordem dos dominicanos, em 1923. Foi um dos fundadores, em 1930 ,da Jeunesse maritime chrétiènne e se engaja, no decorrer dos anos trinta em um intenso trabalho sindical . Lebret adere em 1940 ao projeto de revolução nacional e colabora com o regime de Vichy para a reforma da profissão de pescador em 1941, mas, em seguida distancia-se do governo. Após haver fundado no mesmo ano o movimento Economia e

\footnotetext{
26 na mesma correspondencia de Henry Bagley a Francis Jameson de 26/01/1951 Folder IBEC Technical services, box 5, RG 13 Public Relations ), Rockefeller Family Archives ,RAC

27 conforme sugere a correspondencia de Palmgren para Robert Fulton, em 22/12/1950, a intenção do prefeito era de que Nelson Rockefeller coordenasse a obtenção de fundos -a soma sugerida seria de 5 bilhões de cruzeiros, para um programa de cinco anos- para realizar as obras .Uma carta de Lineu Prestes em 24/01/1951 para Nelson Rockefeller aborda tambem a possibilidade de financiamento. Folder IBEC Technical services, box 5, RG 13 Public Relations ), Rockefeller Family Archives, RAC

28 Em 1956 aparecem as últimas referencias a cidade de São Paulo em estudos realizados pelo IBEC sobre alternativas para a compra de terrenos para a abertura de supermercados, um importante ramo de atividade na America Latina.
} 
Humanismo ele participa às Nouvelles équipes internationales que se batiam pela edificação de uma Europa democrata- cristã , ao mesmo tempo que engaja seu movimento no diálogo com o marxismo. Roma julga, em 1950, este encontro com os comunistas suficientemente perigoso para impor um fim à experiência exigir a destruição dos exemplares não vendidos do livro Signification du marxisme redigido pelo Padre Derosches, o mais próximo colaborador do padre Lebret dentro do Movimento Economia e Humanismo ${ }^{29}$.

O contato de Lebret com a América Latina imprime nova direção aos estudos do Movimento Economia e Humanismo na medida em que inclue a temática do subdesenvolvimento. Tema que no decorrer dos anos 50 se torna dominante nos estudos do padre dominicano.Como observa Antonio Candido ${ }^{30}$, na reflexão sobre o subdesenvolvimento, Lebret sofreu a influencia das idéias de Josué de Castro. Na contramão do pensamento dominante na época que insistia em fornecer uma imagem do Brasil como a terra prometida, onde havia para todos e ninguém morria de fome, os estudos de Josué de Castro revelavam a dura realidade e a incrível desigualdade do pais ${ }^{31}$.

Lebret envolve seus companheiros na questão com o terceiro mundo no contexto de uma crise do Movimento e a partir da decisão de se criar novas equipes internacionais ${ }^{32}$. A América Latina se torna o laboratório de pesquisas em

29 conforme Pelletier, Denis "Economie et Humanisme .De l'utopie communautaire au combat pour le tiers monde 1941-1966"Ed du CERF, Paris , 1996.

30 Antonio Candido "Alguns tópicos para a reflexão"Folha de São Paulo,29/11/99, Ilustrada, $\mathbf{p} 6$.

31 Segunado Antonio Candido, dois livros "Geografia da Fome" (1946) e "Geopolitica da Fome" (1951) se tornaram clássicos e foram traduzidos em diversas linguas.

32 Esta expansão se faz como consequencia das fortes divergências entre o Movimento Economia e Humanismo e o PRP, Partido Republicano Popular e depois de um longo debate interno envolvendo questões chave como a representação politica e a estatização da economia.Com origem no Movimento de Resistência o PRP torna-se a primeira força política democrata cristã que emerge no pós guerra e o segundo maior partido nas eleições pós guerra, perdendo apenas para o PCF. Pelletier descreve as divergências concluindo que naquele momento Economia e Humanismo estava politicamente muito a direita, ao recusar a democracia parlamentar e os sistema de partidos e socialmente muito a esquerda ao defender a nocão de democracia econômica - nacionalização, comitês de empresas, .opus cit p 147 e 153.0 autor atribue a posição política de Lebret marcado pelo ideal tomista de uma comunidade que produz a sua propria elite - "tudo se passa como se tratasse para ele de substiutuir a tecnica de representaçào pela metafísica da presença"opus cit ,p 152. 
planejamento urbano ${ }^{33}$ que se transformam em pesquisas de desenvolvimento econômico. Ao fundar Economia e Humanismo, o padre Lebret desejava elaborar uma teoria onde o enfoque científico da economia política viria renovar a doutrina social da Igreja católica.

Um pensamento reformador formulado no sentimento da solidariedade .A partir do contato com o terceiro mundo ele transforma a primeira versão da economia humana 'em uma dinâmica de desenvolvimento harmônico' que participa da elaboração no decorrer dos anos cinquenta das teorias econômicas de desenvolvimento ${ }^{34}$.

A discussão sobre o significado de desenvolvimento harmônico será uma das questões extremamente polemicas para as equipes brasileiras que se formavam. $O$ depoimento de Celso Lamparelli evidencia os limites da adoção do conceito em uma perspectiva de transformação econômica que não incluía a luta de classes ${ }^{35}$.

\section{As primeiras pesquisas no contexto após a segunda guerra e a importância do} curso dado na Escola de Sociologia e Política de 14/04 a 5/06 de 1947 no itinerário intelectual do P. Lebret

Pelletier analisa o significado do trabalho na América Latina e porque o padre Lebret se dirige ao terceiro mundo, após o esforço de reconstrução na Europa, depois do fim da segunda guerra. Ele enfatiza o novo rumo teórico que se imprime ao movimento, agora claramente marcado pela ideologia marxista e que vem à público na série de palestras que Lebret fez na Escola de Sociologia e Política, em São Paulo, em 1947.

33 o termo utilizado é aménagement de territoire que poderia ser traduzido por ordenação do território.

34 Mais tarde ele reinveste esta experiência adquirida nos trabalhos do Concilio conforme Pelletier, 1996: 10).

35 " $E ́$ importante lembrar que os próprios marxistas franceses dessa época de 60 rejeitaram a luta de classes .Quer dizer eles estavam passando por uma fase de expansão do capitalismo em que há o progresso e o desenvolvimento de após guerra, o que dava uma ilusão de que não haveria mais crise no capitalismo.E a concepção que o Lebret defendia era de um desenvolvimento harmônico, integrado, com uma possibilidade de redistribuiçã". Revista Espaço \& Debates no 4 p 160. 
Estas palestras dirigidas a um público de estudantes e intelectuais e ,mais tarde , organizadas em quatro volumes, consistem na primeira tentativa de síntese da economia humana enquanto prática e como resposta teórica aos impasses da economia política .Quatro capítulos, dos mais longos, são consagrados ao marxismo, dois ao leninismo è à economia soviética. De acordo com o autor constituem 36 "uma etapa chave de seu percurso intelectual. Elas fecham um ciclo aberto em 1938 , ligado aos anos de guerra è utopia comunitária que marcou o início da Economia Humanismo. Entre um catolicismo marcado pela herança Tomista e o reencontro com o marxismo é assim elaborada uma reflexão econômica, em oposição à tradição clássica , encontrando ,pelo viés da pesquisa social e graças ao apoio do CNRS, o esforço de modernização empreendido pelos governos da VI República" Neste contexto se organizam as equipes de pesquisa conhecidas pela sigla SAGMA ${ }^{37}$.

\section{Lebret e o meio religioso e político no Brasil}

Pesquisando os escritos de Lebret, diários e correspondência ,Pelletier descreve os primeiros anos de formação do Movimento Economia e Humanismo no Brasil e observa os primeiros cinco anos como esclarecedores do meio em que circula e a forma como se estabelece a rede de contatos. É no meio político anti Getulio,católico, conservador aproximando -se até com o integralismo que são feitos os primeiros contatos $^{38}$. Porem com o inicio dos trabalhos de pesquisa os contatos vão se

\footnotetext{
36 No livro, nota de rodapé descreve o título dos capítulos do curso datilografado em 4 volumes e que permaneceu inédito "Introduction généralle à l'économie humaine"Os primeiros capitulos consistem em uma leitura do Capital de Marx , a sintese das posições de Marx - Engels, as estruturas soviéticas e o leninismo.Em seguida, na segunda e terceira parte, desenvolve o que consiste a economia humana .Pelletier, Denis opus cit p 101.

37 SAGMA eram equipes de pesquisa , as mais estruturadas, do Movimento Economia e Huamnismo. Aparecem no pós guerra a partir de acordo feito entre Lebret e o ministro da Reconstrução Raoul Dautry .Lebret defende a posição de uma politica de reconstrução eficaz a partir de um conhecimento preciso do estado da habitação Convencido, Dautry encomenda uma pesquisa nas cidades de Lyon, Saint Etenne, Nantes, e Marseille.( p 93.Nestas cidades se fazem as primeiras experiências de conjunto habitacional de Corbusier.

38 Através do curso ministrado na Escola de Sociologia e Politica e dos dominicanos conhece Alceu Amoroso Lima , figura de destaque no meio católico na época e que o coloca em contato com dirigentes da UDN, partido político que representava uma "coalisão liberal conservadora" Estes dirigentes eram militares e anti Getulio como o general José Americo Gomes ,o brigadeiro Eduardo Gomes e general Juarez Távora.
} 
restringindo aos meios mais progressistas.

A aproximação de Lebret se faz com políticos da UDN e ,por ironia ,o retorno de Getulio Vargas ao poder ,pela via democrática, possibilita a constituição de uma rede de apoio às idéias de Economia e Humanismo.

Lebret consegue no Brasil o que não havia conseguido na França ,nos anos 40 .A influência passa pela integração ao aparelho de estado ao nível estadual mais que ao nível federal de equipes formadas no contato com Economia e Humanismo .Lucas Nogueira Garcez , em São Paulo, José Arthur Rios, no Rio de Janeiro e Antonio Bezerra Baltar, em Recife, são três exemplos.

Os primeiros trabalhos de pesquisa são realizados no Rio, em 1952, na recém criada Fundação Getúlio Vargas. José Arthur Rios, um dos membros das equipes de Economia Humana tornara- se em 1952 coordenador da campanha nacional de educação rural no quadro do serviço Social fundado por Vargas em junho deste mesmo ano.

Consultor da Comissão de Bem Estar Social de Josué de Castro o padre Lebret ajuda a instalar uma pesquisa sobre o nivel de vida em 34 cidades brasileiras $O$ questionário é elaborado segundo o modelo Economia e Humanismo e Josué de Castro encarrega o padre Lebret de redigir um capítulo de interpretação que será adicionado ao relatório e publicado em $54^{39}$.

Graças à eleição de Lucas Nogueira Garcez ao governo de São Paulo é assegurado o início da atividade de pesquisa da SAGMACS em São Paulo.$^{40} \mathrm{~A}$ pesquisa encomendada por Lucas Garcez sobre as possibilidades de desenvolvimento do Estado

${ }^{39}$ Louis Joseph Lebret "A pesquisa brasileira de padrões de vida"Serviço Social , 1954 XVI -72 p 10=47 Feuillets d'enquêtes et d'instructions aux enqueteurs NA 45 e AS 103 in Pelletier, Denis, 1996,opus cit , p 305.

40 Getulio se aliara ao governador de São Paulo, Adhemar de Barros para as eleições presidenciais. Eleito Getulio, Adhemar ocupa o Ministerio de Transportes deixando livre o cargo de governador do Estado.Em 50 a coligação PSP de Basrros e PTB de Getulio elege para o governo de São Paulo, Lucas Nogueira Garcez. 
de São Paulo é redigida durante os meses de junho a agosto de 52 , depois de seis semanas de contato global com o Estado, sobrevôo do território de avião, entrevistas com personalidades locais , consultas estatísticas e da literatura econômica existente. 0 resultado é um relatório de 64 páginas ${ }^{41}$.

O relatório sobre a conjuntura econômica paulista em relação à do Brasil faz propostas de desenvolvimento econômico fundadas em uma nova divisão regional e a revitalização de municípios. $O$ relatório chama a atenção para o crescimento anárquico de São Paulo e recomenda a reforma das estruturas agrárias .

Esta primeira missão é bem acolhida pelo governo e confirma a necessidade de uma pesquisa de caráter regional Ao longo de 1953 é encomendada uma pesquisa à SAGMACS pela Comissão da Bacia Paraná Uruguai (CIBPU) que reunia oito estados .esta pesquisa se desdobra, em seguida em um aprofundamento para o Estado de São Paulo ${ }^{42}$.

Esta missão é importante porque o método utilizado servirá de modelo para pesquisas posteriores. Ela aborda o nível de vida e necessidades das populações rurais do Estado .O estudo preciso de 64 municípios conduz a propor uma divisão do Estado em onze regiões formadas cada uma de três a oito zonas homogêneas no plano econômico.

Este mesmo método e esquema de abordagem é utilizado em seguida em uma pesquisa sobre os níveis de vida das zonas rurais no Estado do Paraná também realizada para a CIBPU.

A última pesquisa do período aborda as condições de desenvolvimento e de

41 “Conclusions provisoires du voyage d'etudes affectué par L J Lebret et B Santa Cruz a la demande du gouverneur de São Paulo ( ler juin 31 aout 1952) 64 pages dactylographées AN45 AS 102 in Pelletier, Denis, 1996,opus cit, p 306

42 "Problemas de desenvolvimento, necessidades, possibilidades do Estado de São Paulo"São Paulo, CIBPU , 1954, 550p, 11 volumes de plantas 302 p in Pelletier, Denis ,1996,opus cit, p 306 
industrialização do Estado do Pemambuco e do Nordeste. ${ }^{43}$.Uma equipe Economia e Humanismo é fundada em Recife por iniciativa de Benevenuto de Santa Cruz e por um jovem engenheiro e sociólogo Antonio Bezerra Baltar .Em Recife, Economia e Humanismo se beneficia do apoio do arcebispo D. Helder Camara.

Esta pesquisa se inscreve em um quadro de uma mobilização em favor do desenvolvimento do nordeste brasileiro. Este quadro tem por um lado a fundação do Banco do Nordeste em 1952 , a política de Vargas de reequilibrio regional e a fundação, também em 52 da CODEPE Comissão de desenvolvimento de Pernambuco com quem foi negociado o contrato de pesquisa da SAGMACS.

São elaborados dois estudos ${ }^{44}$ : o primeiro é uma proposta de desconcentração da economia com a localização de industrias em cidades de médio porte em tomo da capital ; o segundo, complementar detalhava uma proposta de localização de atividades para o Recife e desenvolvia as ligações viárias com a rede de cidades. A pesquisa propriamente dita é conduzida por Souza Barros pela CODEPE e por Baltar pela SAGMACS.O padre Lebret só participa ao final em duas semanas de contato global seguido de uma interp retação de conjunto.

As pesquisas SAGMACS se situam no ponto de encontro político entre o govemo federal e os poderes regionais - como o mostra o contrato com Lucas Garcez que se elegera governador e São Paulo a partir de um acordo entre Vargas e Adhemar de Barros.

Elas se inscrevem na lógica geral do desenvolvimentismo e de intervenção dos poderes públicos na gestão econômica do país. Observam -se, porem, diferenças importantes A política de Vargas indica um sentido de concentração de poder do Estado federal, as pesquisas de SAGMACS indicam, por outro lado, uma intervenção a nível estadual, o

43 "Estudo sobre desenvolvimento e implantação de industrias interessando a Pernambuco e ao Nordeste , Recife, CODEPE, 1955, XII + 80p e mapas AN45 AS 105 in Pelletier, Denis , 1996 opus cit $\mathrm{p} 307$

"44 Os estudos são "Diretrizes para um plano regional para o recife 1951 "e "Idéia de um zoneamento e de vias rápidas para o Recife" in Leme, Maria Cristina da Silva (coord)1999, opus cit.p 430 
que poderiam significar um contrapeso à centralização do governo Vargas. Indicam também, pelo menos no caso de São Paulo e Paraná , uma valorização do papel dos municípios o que confirma um projeto global de descentralização de poderes.

\section{A formação da SAGMACS em São Paulo}

A característica essencial da segunda metade dos anos cinquenta foi a progressiva independência da SAGMACS em relação ao movimento Economia e Humanismo.As dificuldades do Padre Benevenuto de Santa Cruz contribuíram para este afastamento .Em março de 1954 a antiga hostilidade do cardeal arcebispo de São Paulo em relação à Economia e Humanismo acaba por dar frutos e Santa Cruz é designado para o convento no Rio de Janeiro e interditado de vir à diocese de São Paulo. Esta sanção assim como tensões internas na equipe conduziram os leigos a assegurar o essencial da responsabilidade no interior da SAGMACS renovando assim a ligação com o início da associação ${ }^{45}$

O suicídio de Vargas não afeta politicamente a SAGMACS. Em São Paulo, Janio Quadros sucede Lucas Garcez .Ele vinha do Partido Democrata Cristão PDC, fundado em 1948, à margem da Liga eleitoral católica e cujo primeiro presidente Arruda Camara, bispo de Recife foi um dos raros a apoiar SAGMACS.O PDC contava também entre seus dirigentes com Franco Montoro que ,como Lucas Garcez ,esteve no primeiro escritório da SAGMACS em São Paulo.

Janio Quadros mantém a CIBPU. Em fevereiro de 55 foi negociada uma nova missão de planejamento em três estados do sul : Paraná, Santa Catarina e Rio Grande do $\mathrm{Sul}^{46}$.

Pouco depois o novo prefeito de São Paulo, Wladimir de Toledo Piza ${ }^{47}$ propõe uma

\footnotetext{
45 Pelletier,Denis, 1996 opus cit p 321

46 Manuscrito do Relatório em NA 45 AS160 "Paraná, Santa Catarina Rio Grande do Sul Necessidades e possibildades".

47 Seu contato com as ideias de Lebret vinham das primeiras palestras na Escola de Sociologia e Politica e Politica.impressionado participara da tradução e edição do livro "Princípios para a ação"Suplemento Especial Folha de São Paulo, 1968, p 362
} 
pesquisa sobre o desenvolvimento urbano de São Paulo que André Franco Montoro pressiona Lebret a aceitar.

A SAGMACS em São Paulo, como nos outros estados é formada segundo o modelo francês. Concebida como um laboratório de pesquisa social a formação da SAGMACS em São Paulo se faz por subscrição do Jockey Club. Os primeiros contatos foram com Luis Cintra do Prado- ex diretor da Politécnica, Dr Freitas diretor da Escola Paulista de Medicina, engenheiro Lucas Nogueira Garcez e Franco Montoro, secretário geral da Ação Católica paulista.

Como se observou a inserção política da SAGMACS era ampla, os contatos na Igreja iam do meio integralista católico, á juventude operária católica $\mathrm{Na}$ medida em que se consolidava a ação do grupo pela realização de pesquisas este leque de alianças se estreitava ${ }^{48}$. Colocadas em campo por equipes brasileiras as duas pesquisas foram coordenadas por Lebret e Delprat e terminadas simultaneamente no início de 1958 no momento em que Adhemar de Barros assumia a prefeitura de São Paulo.

Por outro lado, Lebret apenas controla os resultados da pesquisa sobre o desenvolvimento urbano de Belo Horizonte que ele negocia para a SAGMACS em março de 1958. O estudo para Belo Horizonte ${ }^{49}$ é elaborado com urbanistas mineiros e parte da equipe paulista reforçando o desenvolvimento e a difusão do método definido por Lebret e seguido pelas equipes SAGMACS. A cidade é estudada como parte e em função da região. Ela constitue a região e é definida por ela. Esta é uma diferença fundamental dos estudos urbanos e regionais realizados até aquele momento em que a região era entendida como uma extensão da cidade .

\footnotetext{
48 Uma pesquisa sobre o problema social do menor foi interditada pela intervenção de uma instituição católica e o Jockey Club suspende o financiamento após uma pesquisa que denunciava a condição miserável dos jockeys .Conforme correspondência Le Duigou-Santa Cruz, 15maio, 29, julhoe 27 novembro 1949, NA 45 AS 104, apud Pelletier, Denis, 1996,opus cit, p 299. $49^{\prime} \mathrm{O}$ trabalho foi contratado pela Prefeitura de Belo Horizonte (lei municipal 730 de $2 / 8$ / 1958) e elaborado pela SAGMACS ,com escritório em São Paulo . Participaram da redação do Relatório:

Annibal Villela, Antônio Bezerra Baltar, Antônio Delorenzo Netto, Beneveenuto de Santa Cruz, Celso Lamparelli,Francisco Whitaker Ferreira..O Anexo sobre o Abastecimento de Belo Horizonte foi redigido por Fernando Correia Dias, Margarida Luiza Ribeiro, Pedro Galéry,Silviano Cançado Azevedo.
} 
No começo dos anos sessenta enfim uma nova pesquisa da CIBPU sobre o desenvolvimento de três outros estados membros da Comissão : Mato Grosso, Goias e Minas Gerais foi a ocasião da incorporação da SAGMACS no interior do aparelho estadual de desenvolvimento do Estado de São Paulo sob o governo de Carvalho Pinto que havia sucedido Janio Quadros em 1959.

\section{Sobre o método de pesquisa do Movimento Economia e Humanismo}

Para fins dos nossos estudos sobre as transferências no campo do urbanismo no Brasil são importantes as informações de Pelletier comparando Frederic Le Play e o padre Lebret quanto à formação e métodos de pesquisa .

Nas origens do urbanismo que se forma no Museu Social, no início do século na França, têm como formação os ensinamentos de Le Play. Chegaram ao Brasil através ,principalmente, do arquiteto francês Donat Alfred Agache em seu primeiro plano realizado no Brasil em 1927 no Rio de Janeiro. A prática da pesquisa que confere o caráter mais próximo de ciência ao urbanismo vem também desta tradição de sociologia aplicada. O paralelo entre Le Play e Lebret se impõe, segundo Pelletier ${ }^{50}$, pelo fato de serem os dois figuras maiores da tradição de um pensamento econômico católico,com um século de intervalo entre eles.

Ele recusa a idéia de uma influência direta de Le Play sobre Lebret que só raramente fala dele.Esse silencio poderia ser atribuido ao fato de Lebret não querer parecer adotar posições conservadoras Porém as semelhanças existem tanto entre a obra como entre as trajetórias : os dois tem origem no meio católico, rural ,portuário, passaram por uma formação científica de engenheiro, Politécnica e Minas para o primeiro e Naval para o segundo. Os dois foram grandes viajantes e os dois elaboraram à margem da universidade uma ciência social subordinada à ação imediata. Os dois constroem modelos científicos para o conhecimento da sociedade apoiando-se nas ciências naturais, o mesmo apoio sobre a moral católica no início de uma análise que se reivindicava como empírica , a mesma ênfase sobre a pesquisa monográfica que constitue um conhecimento íntimo do objeto de estudo ${ }^{51}$.

50 Pelletier,Denis, 1996,opus cit, p132

51 Pelletier, Denis, 1996,opus cit, pg13 
Entretanto as formas de pesquisa diferem em pontos essenciais : a pesquisa Economia e Humanismo se elabora na tensão entre o qualitativo e o quantitativo entre a monografia e a estatística.$O$ método definido por Le Play , a partir da pesquisa das famílias ,procura chegar a uma tipologia das famílias européias, utiliza o método indutivo em uma passagem do particular para se chegar ao geral. Ao contrário, as pesquisa da Economia e Humanismo não procuram os "tipos" de famílias mas através do confronto entre múltiplos estudos de casos analisam a as causas do desaparecimento das comunidades, investigam as doenças da sociedade urbana moderna.

Conforme Pelletier as pesquisas do Movimento Economia e Humanismo têm um forte conteúdo normativo e moralizador marcado por uma ordem social cristã. Porém este viés ruralista, marcado pelo ideal comunitário e cristão da primeira fase do Movimento é substituído tanto na França quando fazem pesquisa sob contrato dos ministérios da reconstrução no pós guerra como nas primıiras pesquisas no Brasil por um movimento de laicização. $O$ ideal de uma familia cristã organizada permanece apenas nos manuais mas desaparece na formulação da pesquisa e na interpretação da informação coletada.São feitas também adaptações a cidades de outro clima e outra situação econômica.

A passagem de uma reflexão sobre o desenvolvimento econômico para uma análise territorializada da sociedade deve-se ao encontro do Padre Lebret e de seus colaboradores com o arquiteto e urbanista francês Gaston Bardet ${ }^{52}$.

52 Arquiteto estudou com Marcel Poète, seu futuro sogro, no Instituto de Urbanismo de Paris .Elabora uma serie de estudos de urbanismo entre eles o plano de extensão para Vichy em 1939. Muito crítico em relação aos princípios da Carta de Atenas e de Le Corbusier em particular. Após a guerra ele se encontra marginalisado no meio intelectual frances e se desloca para Bruxelas onde funda o Instituto Superior de Urbanismo Aplicado .Neste instituto forma muitos alunos latino americanos que se constituem em uma nova rede de relações profissionais .Ele faz trabalhos de urbanismo para a Argentina e Venezuela .No Brasil , ele mimistra um curso intensivo de urbanismo na escola de Arquitetura da Universidade de Minas Gerais .Este curso dirigido a alunos e professores teve uma duração de quatro meses, se encerrando no dia 29 de junho. Ele passa por São Paulo onde pronuncia uma série de conferências na Escola de Sociologia e Política sobre os seguintes temas:

Sociologia e Urbanismo, Escala Comunitária, Nova estrutura rural e Simbiose cidade campo .Leme, Maria Cristina( coord) 1999, opus cit, p 543. 
Bardet propõe uma nova forma de organização espacial urbana e regional a partir de relações comunitárias, introduzindo uma espacialidade à teoria desenvolvida pelo movimento Economia e Humanismo. $\mathrm{O}$ arquiteto francês publica uma série de artigos na revista Economia e Humanismo no período entre 1943 e 1948 divulgando suas idéias.

A economia humana desenvolve uma teoria das necessidades ${ }^{53}$ Divididas em três classes sendo a primeira da dignidade; a segunda do conforto e a terceira do depassement $^{54}$ Estas classes não indicam apenas acesso a bens materiais mas também a instrução, ao culto, à consciência política enfim à cidadania. Segundo Lebret, a verdadeira prosperidade se exprime nos bens primários, os terciários ,muito importantes, não são mensuráveis, como o tempo livre dedicado à pesquisa cientifica desinteressada , a criação artística. A classificação indicaria também uma hierarquia de valores.

Uma das grandes dificuldades deste método estava na construção da escala de valores para cada critério não quantificável. Desenvolveu-se uma técnica de construção de diagramas. Cada atributo pesquisado recebia uma nota e uma representação gráfica no diagrama que superpostos gerariam uma visualização qualitativa e quantitativa.

\section{As contribuições da SAGMACS para o urbanismo paulistano}

Para os estudos urbanos em São Paulo três são as principais contribuições do método introduzido por Lebret. A percepção da diversidade sócio econômica na composição de bairros da cidade e principalmente a compreensão da existência da periferia e de sua relação dialética com o centro tem a nosso ver um enorme impacto na formulação do pensamento urbanístico em São Paulo. Derivam do conceito de desenvolvimento e sub desenvolvimento elaborados por Lebret nos seus estudos para a América Latina.

O terceiro está diretamente vinculado aos dois primeiros. É a formação de um

\footnotetext{
53 Este seria um ponto importante em comum com as pesquisas de Chombart de Lauwe, segundo Lamparelli, Celso, Revista Espaço \& Debates no 37 , p 92

54 alem do necessário.
} 
profissional engajado tanto no conhecimento profundo de cada situação urbana como também comprometido com a sua transformação.

No manual do pesquisador ${ }^{55}$ podemos seguir os passos para esta compreensão: é recomendada uma visão de conjunto que pode ser feita pela soma de elementos: carta na escala de 1: 50000 , fotos aéreas, vôo sobre o território ,que se de dificil realização pode ser substituído por visões de pontos altos na cidade.

Junta-se à visão de conjunto uma de detalhe: primeiro identificar as grandes zonas por atividade, seguida de uma visita no terreno delimitando os setores, observando as

Ficha de pesquisa .Le quartier niveau de vie . FonteLebret ,L.J. Bride, R. Guide Pratique de l'enquete social Paris, Presses Universitaires de France, 1955

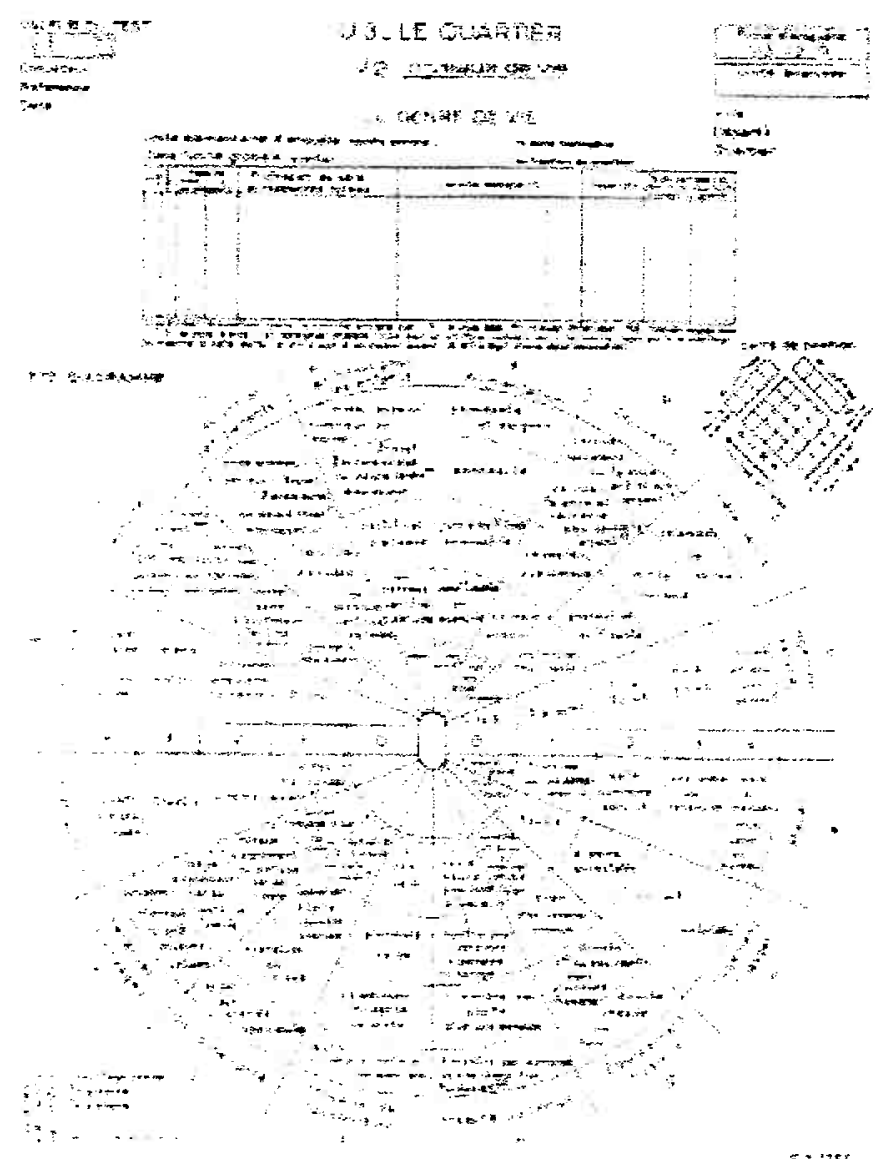

55 Lebret, Louis Joseph "Guide Pratique de l'enquete sociale vol IIIL'enquête urbaine lá analyse du quartier et de la ville"Paris, ed PUF, $1955 \mathrm{p} 9$. 
pessoas. Depois , visitas de carro às zonas periféricas e, percurso a pé, às zonas mais características tanto sob o ponto de vista do conforto, como da miséria. Notar a localização das industrias e visitar pelo menos uma de cada tipo. Percorrer as grandes vias e observar o volume de trafego. No decorrer da visita à periferia observar a ligação por meio de transporte com a cidade, o grau de dependência ou de autonomia em termos de industria e comercio .

Observar as pessoas de diferentes classes sociais nos cafés, nos restaurantes .A recomendação de Lebret era "por todo o lado é preciso escutar, colocar questões, se colocar na escola da realidade" 56 .

Na pesquisa de São Paulo desenvolve-se de forma articulada o estudo urbano e regional. $\mathrm{Na}$ primeira parte "Perspectivas históricas, demográficas e econômica da aglomeração paulistana", uma análise crítica do dinamismo de São Paulo propõe ,com base em dados demográficos, limites ao crescimento urbano. Pela primeira vez um estudo de planejamento urbano de São Paulo inclui estudos da história de formação da cidade desde a fundação, passando pela fase colonial, império ,até a transformação, no século XX, em metrópole.

Na segunda parte, "Estrutura Urbana de São Paulo", era aplicado um método para identificar as formas de organização social em todas a área urbanizada da aglomeração paulistana, incluindo os municípios de São Paulo, Santo André, São Bernardo e Guarulhos. A pesquisa adotava como hipótese a organização em três escalões : elementar, complexa e completa. Aplicando esta classificação foram identificadas três regiões na cidade em função do centro principal e dos sub-centro: a região central, a região externa e a região de transição entre as duas.

A terceira parte do estudo consistiria nos "Aspectos Sociológicos da aglomeração paulistana". Ela não aparece detalhada em itens como as outras partes do estudo ${ }^{57}$.

${ }_{56}^{56}$ Lebret, opus cit, p 10.

57 Não foi localizado nenhum exemplar, até o momento, o que leva a supor que não tenha sido entregue como estudo final. 
A análise urbanística consistiu na coleta por amostragem de informações quanto ao uso e a ocupação do solo, equipamentos básicos, circulação e problemas relativos à legislação urbanística existente.

Elaboram a noção de anomalia ( anomalia na implantação das edificações ; anomalia no equipamento básico; anomalia decorrente do processo anárquico da expansão central e periférica; anomalia da circulação; anomalia da legislação) para comparar as informações levantadas para São Paulo com indices construídos a partir de referências à experiências de planejamento de outras cidades. Os índices assim construídos permitiram comparar as regiões da cidade em termos de densidade residencial e qualidade do equipamento público instalado ( sistema viário e pavimentação, sistema de coleta de esgoto, abastecimento de água, sistema de drenagem de águas pluviais, energia elétrica e iluminação pública). Constatadas as diferenças estes índices permitiam também apontar as causas das desigualdades verificadas.

Além de identificar com clareza a noção de periferia, diferenciava e qualificava as diferentes regiões da cidade a partir de uma compreensão dos processos que estruturavam o espaço intra- urbano. Desta forma introduzia nos estudos de planejamento urbano uma nova noção de periferia como conseqüência de um processo perverso de estruturação urbana.

Os estudos diferenciavam regiões, bairros e centros de bairro na cidade desfazendo uma visão monocêntrica predominante nos estudos sobre São Paulo. Identificava centros constituídos de bairros na cidade ${ }^{58}$. $O$ atraso na identificação da complexidade da estruturação das atividades comerciais na cidade pode ser percebida nos estudos de zoneamento contemporâneos ao estudo da SAGMACS .Em 1955 ,eram propostos como centros de comercio secundário apenas Pinheiros e Santo Amaro ${ }^{59}$.

Vinculada a esta nova visão da organização econômica e social da cidade era proposto um novo modelo descentralizando a administração municipal em sub-

58 Bras ,Mooca Penha, São Miguel, Saúde, Ipiranga , Vila Prudente,Ibirapuera, Indianópolis, Ibirapuera, Santo Amaro, Pinheiros Santana, Vila Maria.

${ }^{59}$ Conforme Feldman, Sarah, 1996, opus cit, p124. 
prefeituras. No sentido intra urbano propunha a decomposição e no outro sentido inseria em um contexto progressivamente mais amplo desde os municípios vizinhos até incluir todo o estado.

Dois fatos contribuíram para que as idéias deste estudo penetrassem na cultura urbanística dos quadros técnicos da prefeitura de São Paulo. Em primeiro lugar por não se interessarem por elaborar um plano diretor não competiram com a equipe local. A equipe do SAGMACS, considerava que os urbanistas do Departamento de Urbanismo da Prefeitura, estavam melhor habilitados para fazê-lo, cabendo a ela apenas as indicações de caráter geral.

Como conseqüência desta articulação entre os urbanistas da prefeitura e a equipe SAGMACS o estudo foi absorvido,mesmo que de forma seletiva, em um relatório do governo de Adhemar de Barros. ${ }^{60}$. 0 segundo capitulo deste relatório publicou partes dos produtos da pesquisa elaborada pela SAGMACS :a análise da atração que identificavam pólos secundários e as necessidades imediatas da população nas unidades elementares.

\section{O Departamento de Urbanismo e a Comissão Orientadora do Plano da Cidade}

Em 1947 , a criação do Departamento de Urbanismo ${ }^{61}$, dentro da estrutura da Secretaria de Obras, sinaliza a crescente institucionalização do planejamento. 0 Departamento tinha por competência "a elaboração, realização e defesa do Plano da Cidade "e para isso contava com as seguintes divisões : de Pesquisas, Regulamentação e Divulgação; de Planejamento Geral; de Desenvolvimento do Plano, Serviço de Biblioteca e Arquivo, Serviço de Pesquisas Urbanas; Serviço Técnico.

O decreto - lei criava ainda a Comissão Orientadora do Plano da Cidade .Formada por representantes do executivo, legislativo, das universidades, de entidades profissionais

60 “ Planejamento 1957 - 1961 " Departamento de Urbanismo,Secretaria de Obras ,Prefeitura Municipal de São Paulo,São Paulo,Prefeitura Municipal de São Paulo,1961. 61 Decreto- lei 431 7/7/47 
tinha por objetivo ap reciar, quando solicitada pelo executivo ou Legislativo Municipal os projetos relativos ao Plano da cidade e os problemas relativos aos serviços de utilidade pública ,podendo também apresentar estudos e sugestões relativos aos problemas de urbanismo. Feldman destaca "que ampliava-se de forma significativa o espaço institucional dedicado ao plano da cidade na administração municipal, dando sequência ao processo iniciado em 1925. De atividade atribuída a uma seção, naquele momento, e a uma subdivisão conforme estabelecido pela reforma de 1936, o plano passa a ter dois órgãos voltados para a sua elaboração - o Departamento de Urbanismo e a Comissão Orientadora do Plano da Cidade" ${ }^{62}$

O decreto não apenas criava o Departamento de Urbanismo mas também os de Arquitetura e de Obras Públicas, separando desta forma, na administração municipal , como as atividades do arquiteto, do engenheiro e do urbanista ${ }^{63}$.

Ocupam os cargos de chefia das divisões e do Departamento de Urbanismo ,engenheiros cuja função principal é a administração pública. Como observamos nos capítulos anteriores, os urbanistas, da geração que os precedeu ,estavam empenhados tanto na concepção do urbanismo enquanto área de conhecimento como aplicavam estes principios em sua prática profissional. Os novos engenheiros municipais têm uma ação mais restrita ao âmbito da prefeitura .Publicam artigos nas revistas especializadas debatendo ou reproduzindo idéias dos dois urbanistas que continuam como figuras chave neste período: Anhaia Mello e Prestes Maia.

Duas revistas começam a ser editadas a partir dos anos cinquenta A Revista de Engenharia Municipal, publicação da Sociedade do Engenheiros Municipais, começou a circular em outubro de 1955 sob a direção de Heitor Eiras Garcia. Abordava assuntos relacionados à evolução da metrópole ,obras e serviços públicos, projetos urbanisticos, legislação municipal e documentação referente à história de São Paulo. O periódico passou a dar cada vez mais importância 'a temática do urbanismo,

62 conforme Feldman, Sarah, , 1996, opus cit p 22

63 conforme Feldman, Sarah, , 1996, opus cit p 27 
revelando uma preocupação quanto ao crescimento desordenado da cidade. Com breve existência a Revista Bem Estar : Urbanismo , Habitação começou a circular em fevereiro de 1958 do arquiteto e professor da FAU USP, Gustavo Neves da Rocha Filho. Ele foi o diretor da revista durante os dois anos e três meses de existência, publicando seis números. A revista teve Brenno Cyrino Nogueira como secretário de redação e vários colaboradores. Priorizou os temas da habitação e do urbanismo sob o ponto de vista da historia e das realizações

A Comissão do Plano da Cidade só é colocada em atividade em 1954 pela lei 4494 e apresenta sua primeira proposta de plano para a cidade. Tratava-se do estudo elaborado por Anhaia Mello “O Plano Regional de São Paulo- Uma contribuição da Universidade para o estudo de um código de ocupação lícita do solo" que finalmente aplicava para São Paulo as teses que vinha desenvolvendo ao longo das ultimas duas décadas .Inicia o documento propondo a articulação do planejamento , do nivel nacional ao local . Está implícita nesta proposta a sua postura metodológica de compreensão de interação entre partes do particular para o geral e vice versa.

No nivel nacional se constituiria uma nova organização, também no formato de Comissão responsável pela elaboração de estudos e planos para as cinco regiões do país (norte/sul/centro/leste/oeste) .Segue-se, no plano estadual , a proposta de organização de um conselho de urbanismo, a elaboração de um plano para o estudo da distribuição da população e das atividades e a obrigatoriedade, nos moldes franceses, de organização de planos para as cidades acima de uma determinada população.

Um fato novo, Anhaia propunha uma instancia intermunicipal, articulando municípios em torno de São Paulo para tratar das questões em comum: saneamento, energia, comunicações, localização de industrias e atividades agrícolas. No nível municipal e da cidade ele detalha as idéias que vinha divulgando nos artigos publicados nas revistas de urbanismo: defende a tese da limitação do crescimento de São Paulo através da descentralização industrial e adoção do repertório do modelo cidade jardim como forma de organização territorial .0 "esquema Anhaia "como ficou conhecido este estudo estabelecia um limite preciso, que ele denomina de urban 
fence a partir do qual ficava impedida a expansão da cidade .Fixava limites às alturas das edificações comerciais, estimulava a adoção da unidade de vizinhança nos novos loteamentos e cobrança da taxa de melhoria dos proprietários favorecidos por melhoramentos urbanos.

As propostas de Anhaia despertaram intensa polêmica entre os urbanistas e fortes críticas no parecer de Prestes Maia por encomenda da própria Comissão ${ }^{64}$, principalmente porque a proposta de limitação ao potencial construtivo é encaminhada ,sob forma de legislação, pelos engenheiros do Departamento de Urbanismo. A lei 5261 limitava a densidade ao fixar o coeficiente de aproveitamento máximo de seis para edificios comerciais e de quatro para os edificios residenciais, densidade liquida residencial máxima de 600 habitantes por hectare e área mínima de 35 metros quadrados de terreno por habitação.

Carlos Brasil Lodi diplomado engenheiro arquiteto em 1933 pela Escola Politécnica, é um exemplo interessante na formação de quadros técnicos em planejamento urbano na Prefeitura de São Paulo. Foi estagiário na seção de Arquitetura e após se formar trabalhou sempre na prefeitura.

Na primeira gestão de Prestes Maia (1938-1945) trabalhou no detalhamento de suas propostas urbanísticas.Foi o diretor, a partir de 1950 , da divisão de Planejamento geral da cidade e depois diretor do Departamento de Urbanismo .Afinado com as idéias de Anhaia Mello, fe $\mathrm{z}^{65}$ críticas importantes ao planejamento apenas viário que se fazia em São Paulo. Atento à formação de loteamentos clandestinos Carlos Lodi é excessão no departamento por suas posições politicas .Aponta como uma das causas da formação de loteamentos clandestinos ,a estrutura viária radial, a diferença de tratamento entre a área central onde se localizavam os melhoramentos e a periferia , objeto apenas de legislação regulando os arruamentos. Defende uma legislação mais exigente quanto aos loteamentos serem comercializados com infraestrutura instalada.

64 ver sobre o embate de posições entre Anhaia e Prestes Maia Meyer, Regina "Metrópole e Urbanismo São Paulo, anos 50"tese de doutoramento, FAUUSP, 1991.

${ }^{65}$ Lodi, Carlos "Planejamento Geral" in Ciclo de Conferencias da Secretaria de Obras, São Paulo , Gráfica Municipal , 1949 
$\mathrm{Na}$ palestra que faz no Instituto de Engenharia ${ }^{66}$ retoma o conteúdo do relatório da administração de Adhemar de Barros na prefeitura “ Planejamento 1957 - 1961 " quando era diretor do departamento de Urbanismo.Através deste relato é possivel se perceber as questões em pauta no departamento naquele período. Ele inicia definindo planejamento como processo "o que deve prevalecer é o conceito dinâmico de planejamento, não podendo o mesmo ser ocasional e definitivo, mas constante e flexivel, e sendo o Plano diretor apenas um instrumento, dos mais importantes sem dúvida, do próprio processo de planejamento cujo principal caráter é o da continuidade" ${ }^{\text {6? }}$. O primeiro capitulo do documento da prefeitura reproduzia parte da pesquisa elaborada pela SAGMACS.

O segundo capítulo abordava o plano viário e de transportes. Lodi defende nos planos s das cidades a adoção do que denomina esquemas abertos e vias diametrais em lugar de padrões definidos como o radio concêntrico e o em xadrez. Relata para o caso de São Paulo as transformações propostas no Plano ${ }^{68}$ em relação ao sistema originalmente radio concêntrico convergindo para o perímetro de irradiação .0 sistema incluía vias expressas diametrais, algumas já existentes e outras projetadas que se interligariam na zona central Propunha ainda uma ligação perimetral periférica de forma a interligar as rodovias Dutra, Anchieta e Anhanguera e estabelecendo ligação entre os bairros.

Quanto ao transporte propõe duas linhas de metrô ${ }^{69} \mathrm{com} 20 \mathrm{~km}$ de extensão cada uma servindo a diretriz Lapa - Centro - Penha e a outra, na diretriz Pinheiros - Barra Funda - Ponte Grande- canindé Bras - Mooca - Ipiranga.

66 Lodi, Carlos "Situação do planejamento da cidade de São Paulo" em 1960 Revista Engenharia, no 226 set 1961

${ }_{67}$ Lodi, Carlos, opus cit, p55

$68 \mathrm{O}$ sistema projetado era hierarquizado em vias expressas, principais urbanas, principais locais e locais.

69 Dois estudos precedem esta proposta de metro Um elaborado, em 1945, por Mario Lopes Leão, denominado "O Metropolitano de São Paulo" e outro, em 1955, a pedido do prefeito Lino de Matos havia sido realizado amplo estudo do metropolitano ,por uma Comissão coordenada por Prestes Maia.Este estudo denominado "Ante projeto de um sistema de transportes rápido metropolitano". 
No capitulo seguinte relaciona a estruturação urbana à legislação, zoneamento e organização. Chama especial atenção para o plano de divisão distrital da cidade proposta de uma nova divisão administrativa do município. Quanto ao zoneamento havia sido realizado uma classificação das industrias e de sua localização no município e pesquisados terrenos aptos à instalação de novas atividades visando um zoneamento industrial. São propostas zonas ao longo dos rios Tietê e Tamanduateí e em trechos ao longo do rio Pinheiros. Apresentaram toda a legislação de uso e aproveitamento do solo de todo o município ${ }^{70}$, todos os arruamentos aprovados $\mathrm{e}$ levantamento de todas ruas públicas, base como afirma Lodi "para um zoneamento residencial entrosado com seus núcleos comerciais e suas zonas de industria local e para uma ação municipal voltada para a defesa dos espaços livres de arruamento" Anexo ao relatório era apresentado um projeto de lei de zoneamento com a regulamentação do parcelamento do solo, classificação do sistema viário, estabelecimento de zonas de uso com categorias de uso e indices urbanisticos.

\section{A penetração do Urbanismo modernista}

\section{"A cidade é uma casa}

a casa é uma cidade" Artigas, 1969

Ao mesmo tempo que se desenvolvia a linhagem de urbanismo, formada desde o século XIX a partir das Escolas de Engenharia , uma outra formada principalmente por arquitetos começa a se configurar nos anos trinta .Nesta vertente o urbanismo é concebido a partir da arquitetura na relação entre o espaço edifícado e o espaço livre. Tem como objetivo principal a atividade do projeto e da construção de novos espaços urbanos, de novas cidades. A tecnologia da construção define o projeto. Esta vertente se define a partir das idéias veiculadas pelos Congressos do CIAM. Tendências diferentes definem uma periodização destes congressos. A que chega ao Brasil é

\footnotetext{
70 Feldman descreve em sua tese de doutorado o processo de elaboração da legislação de zoneamento de 1947 a 1957.Em 1955 havia sido encaminhado o projeto de lei elaborado por Rogério Cesar de Andrade Filho consolidando propostas elaboradas em 1947, 1949 e 1952.0 projeto incluía divisão do município em zonas de uso com descrição de perímetros, classificação de usos, áreas, recuos e alturas .

${ }^{71}$ Lodi, Carlos, 1961, opus cit, p 62
} 
dominada pelas idéias de Corbusier. A versão da Carta de Atenas do arquiteto suiço influencia a produção dos arquitetos brasileiros como pode ser observado nas propostas para o concurso do Plano Piloto de Brasília.

As teses do Movimento já circulavam no meio técnico paulistano como pode ser percebido pelas citações de Prestes Maia, no Plano de Avenidas às propostas de Le Corbusier para a hierarquização da circulação viária e verticalização e a referência à habitação mínima de Walter Gropius. A revista Engenharia Mackenzie publica em 1929 uma tradução do artigo "Architetura da época machinista" de Le Corbusier. São ainda referências esparsas e consideradas, nas palavras de Prestes Maia , fantasiosas. Em São Paulo as adesões ao Movimento Moderno são, desde o início, importantes porem isoladas $^{72}$.

A passagem de Le Corbusier por São Paulo e Rio de Janeiro em 1929 e o retorno em 1936 foram momentos importantes para a difusão deste movimento no Brasil. Ele profere duas conferências no Rio :a primeira sobre arquitetura - Revolução Arquitetural - e a segunda sobre Urbanismo. Estes dois temas estão estreitamente articulados em sua fala- a cidade e a arquitetura moderna .

A revista Movimento Brasileiro ${ }^{73}$ as reproduz em parte ."Depois de fazer varias considerações de ordem geral e doutrinárias, em tomo do problema do urbanismo Le Corbusier explicou, por desenhos, a origem da cidade, o primeiro nucleo até os desenvolvimentos espantosos modernos. Traçou o modo por que ela cresceu, $o$ caminho dos burros em linha curva, pela qual se comunicava com a peripheria, as defesas militares, o nascimento dos arredores, em summa toda a sua vida até que o apparelhamento moderno criou as grandes metrópoles, cidades de desespero O urbanismo appareceu da necessidade de resolver o problema da cidade. Preocupada

72 Gregorio Washavchik escreve o manifesto a favor da arquitetura moderna em 1925. Na viagem a São Paulo Le Corbusier conhece a casa de Vila Mariana e indica o arquiteto a ser representante no CIAM. Dois anos depois ,o projeto de Flavio de Carvalho no concurso para a construção do palácio do Governo foi , segundo Daher o mais discutido entre os que participaram do concurso .O próprio autor afirmava que no projeto prevalecia a doutrina corbusiana modificada para melhor. Daher, Luis Carlos "Flavio de Carvalho: arquitetura e expressionismo" São Paulo, Ed Projeto, 1982.

73 conforme fac - simile da revista Movimento Brasileiro in Santos, Cecília Rodrigues et altrii"Le Corbusier e o Brasil", São Paulo, Tessela , Projeto ed, 1897, p 57 e 58 
com a felicidade ou desgraça do homem eis uma sciençia que demonstra ao mesmo tempo a solidariedade projectando uma vontade poderosa para um fim claro, constructor e criador. $O$ urbanismo é questão de apparelhamento. $O$ seu aspecto fundamental não é esthetico, mas econômico, a belleza virá depois .E a propósito deu o seu conceito de belleza como o estudo da satisphação plena, do contentamento do homem deante da ordem e da harmonia.(..)

Desenhou então os seus planos da construção moderna. É preciso construir no ar livre. Descreveu a cidade standard com os seus arranha-céus em vidro, como centros de actividade, as casas cellulas, com os seus jardins ao lado, as grandes auto estradas elevadas, para descongestionar o transito em summa segundo o modelo que estaleleceu para uma cidade-modelo de 3 milhões de habitantes".

Nos desenhos-esquemas de sua palestra aparece com ênfase a questão da velocidade representados pelos meios de comunicação : telégrafo ,av.ão.O impacto das suas idéias é ,sem duvida , maior no Rio quando ele fala no Instituto Central de Arquitetos do que em São Paulo, quando ele profere conferência junto ao Instituto de Engenharia. A existência de um meio institucional acadêmico e profissional diretamente ligado à arquitetura explica, a nosso ver, esta maior penetração entre os arquitetos cariocas.

No final dos anos 40 se forma, na maior parte das cidades brasileiras o meio da arquitetura autonomizando -se do da engenharia .Neste movimento, são criadas Faculdades de Arquitetura. Na Universidade de São Paulo, por iniciativa de Anhaia Mello a arquitetura leva com ela o ensino do urbanismo. É criada em 1947 a Faculdade de Arquitetura Mackenzie e um ano depois a Faculdade de Arquitetura e Urbanismo da Universidade de São Paulo. A separação da engenharia confere uma maior consistência à atividade de projeto e novos temas são abordados .A investigação e o projeto de habitação de interesse social é parte do curriculum da nova faculdade refletindo a inserção dos arquitetos paulistas na problemática dos primeiros congressos do $\mathrm{CIAM}^{74}$.

74 O segundo e o terceiro Congressos Internacionais de Arquitetura Moderna em 1929 e 1930 abordam a questão da habitação tendo como paradigma as experiências das municipalidades socialistas na Alemanha e na Austria. 
A referência a palavra urbanismo é rara nos textos dos arquitetos paulistanos.

Encontra- se com freqüência arquitetura e construção cujos significados são mais amplos abarcando da casa à cidade como pode ser visto no texto de João Vilanova Artigas $^{75}$ fonte da citação inicial "construir foi para o homem primeiramente construir sua habitação .Alojar-se no espaço, dominá-lo como parte da natureza. Num belo ensaio sob o título Construir, habitar, pensar, Heideger junta elementos para a prova desta afirmação. Na lingua alemã o verbo construir, nas suas formas linguísticas mais antigas exprimia também habitar e ser. 0 anglo saxão primitivo era porque habitava a sua construção.(...)Construir em alemão é bauen, que tem a mesma origem de ser, revelada na forma bin(sou). As formas lingüisticas para habitar, habitação perderam-se para a definição atual de casa"76.

Uma palavra compartilhada é plano diretor Para os urbanistas com origem na engenharia, plano diretor é um conjunto de estudos e de diretrizes produto da atividade de planejamento urbano. Para os arquitetos urbanistas plano diretor é um detalhamento do plano piloto, sendo este um projeto de cidade. Em 1950 estas duas etapas de um plano urbanístico são desenvolvidas por Le Corbusier e José Luis Sert para a cidade de Bogotá , na Colômbia. "O plano de Bogotá oferece esta particularidade de ser o primeiro onde aparece o principio dos setores urbanos, divisão do terreno em retângulos de superfície e de porte suficientes para organizar e canalizar de uma maneira racional o sistema de circulação de velocidade rápida. $O$ plano piloto é de Le Corbusier e o plano diretor para a cidade é de José Luis Sert .O presidente do CIAM e seu associado foram encarregados de desenvolver o plano de urbanismo colocar em prática o plano piloto em condições locais" Da mesma forma, o concurso de Brasília se identificava com esta vertente ao se constituir em propostas para um plano piloto.

Iniciamos esta parte do trabalho com uma breve descrição dos quatro primeiros

\footnotetext{
75 Formado engenheiro civil pela Escola Politécnica

76 Artigas , João Batista Vilanova Arquitetura e Construção in "Caminhos da arquitetura" 2 a ed São Paulo, PINI , Fundação Vilanova Artigas 1986 p 102, 103
} 
Congressos de Arquitetura Modema ${ }^{77}$.Não se trata apenas de identificar os principais períodos ou as forma de organização que permitiram a difusão de conceitos e métodos. Na comparação entre duas versões da Carta de Atenas, a atribuída a Le Corbusier e a publicada por José Luis Sert procuramos esclarecer alguns dos elementos que explicariam a constatação de uma adesão declarada aos principios da Carta por profissionais vinculados à diferentes correntes de pensamento urbanístico.

\section{Os Congressos Internacionais de Arquitetura Moderna}

Foram dez congressos de 1928 a $1956^{78}$. Conforme observa Tafuri ${ }^{79}$, na segunda metade dos anos 20 , os arquitetos modernos (que ele designa também como arquitetura radical européia ) já estariam organizados, dispondo e utilizando ,largamente, de meios de divulgação. As experiências eram divulgadas em revistas especializadas e os temas da "nova arquitetura" estariam presentes, também , na imprensa diária

A decisão de organizar congressos de arquitetura modema teve por objetivo a

\footnotetext{
${ }^{77}$ Como neste estudo analisamos a formação da vertente do urbanismo modernista em São Paulo nos limitamos a descrever as teses dos quatro primeiros congressos, necessárias para se compreender os princípios em que se basearam os arquitetos paulistas nas suas propostas urbanísticas. No momento em que os membros do CIAM estavam em processo de profunda revisão critica das formulações dos primeiros congressos, no Brasil ainda se percebe a influência dos arquitetos fundadores do movimento de arquitetura moderna.

78 Foram dez congressos de 1928 a 1956 :

$1^{\circ}$ Congresso 1928 Declaração de La Sarraz -afirmam sua opinião sobre os conceitos fundamentais de arquitetura e sobre suas obrigações profissionais..

$2^{\circ}$ Congresso Frankfurt, Alemanha, 1929 Padrões mínimos de vida .

$3^{\circ}$ Congresso Bruxelas, 1930 Estudo do loteamento racional

$4^{\circ}$ Congresso ,Atenas, 1933, A cidade funcional

$5^{\circ}$ Congresso Paris , 1937( durante a Exposição Arte e Tecnica) Estudo do problema da moradia e do lazer.

$6^{\circ}$ Congresso Bridgwater, 1947 Reafirmação dos objetivos do CIAM

$7^{\circ}$ Congresso Bergamo, Italia, 1949 Execução da carta de Atenas

$8^{\circ}$ Congresso Hoddesdon, 1951 O coração das cidades

$9^{\circ}$ Congreso Aix- en- Provence, 1953 Estudo do habitat humano

$10^{\circ}$ Congresso Dubrovnik, 1956 objetivo "relação mais precisa entre a forma física e a necessidade sociopsicológica"apud apud Frampton , Keneth "História crítica da arquitetura moderna"São Paulo,Ed Martins Fontes, 1997,op cit , p 329330.Neste congresso o CIAM é oficialmente extinto.

${ }^{79}$ Tafuri, Manfredo Dal Co, Francesco, 1991,opus cit , p 211.
} 
articulação do movimento em escala internacional e, certamente, está na forma de organização dos CIAM a capacidade de difusão do ideário em arquitetura e em urbanismo.

No primeiro congresso, em junho de 1928,no castelo de La Sarraz, na Suiça ${ }^{80}$ já estão presentes estes elementos. Apesar de serem apenas arquitetos provenientes de países da Europa, o congresso se propõe internacional .A declaração ${ }^{81}$, em forma de manifesto é assinada por representantes de grupos nacionais de arquitetos modernos.

Afirmam a necessidade de uma concepção nova de arquitetura vinculando- a ao sistema econômico e ao modo de produção industrial. A racionalização e a padronização deveriam estar presentes tanto na concepção - arquitetura - como na realização- construção. Estabelecem a estreita relação entre a arquitetura e o urbanismo. As três funções básicas do urbanismo ( habitar, trabalhar e recrear) devem ser resolvidas em função da relação espaço construído, espaço livre.

São abordados temas polêmicos como a relação com o Estado e a questão da propriedade da terra. A não concordância para uma declaração de princípios comuns sobre estes temas mostram a diversidade das experiências profissionais dos participantes, divergências que se evidenciam nos próximos congressos.

${ }^{80}$ Gideon na introdução do livro de José Luis Sert "Can our cities survive" ao narrar a forma como foi organizado o primeiro encontro, observa que La Sarraz foi proposto e escolhido por ser um lugar neutro, visto que a tentativa anterior de organização de um congresso por arquitetos alemães se frustrara.

81 São completamente diferentes as versões encontradas da Declaração de La Sarraz .Segundo a publicação "Congrés Internationaux d'Architecture Moderne"Coleção Documentos del siglo veinte, Buenos Aires, Artes Graficas Alfonso Ruiz, , 1957 , a Declaração é composta dos seguintes capítulos: economia geral, urbanismo ( 3 funções fundamentais : habitar, trabalhar circular ; objetos : ocupação do solo, organização da circulação, legislação) a arquitetura e a opinião, a arquitetura e o estado( crítica a arquitetura suntuária das academias .Frampton ao iniciar o capitulo sobre o CIAM destaca cinco pontos da Declaração de La Sarraz, que coincidem apenas em parte com a versão anterior: a necessária relação entre arquitetura e o sistema economico e entre arquiteura e o modo de produção industrial (racionalização e padronização)Frampton, Kenneth, 1997opus cit, p 327 
Conforme observa Benevolo ${ }^{82}$, os arquitetos alemães e italianos vinham de uma experiência de trabalho junto ao estado, com maior consciência dos compromissos e limitações desta relação. Le Corbusier representava uma outra corrente que pretendia manter independência em relação ao aparelho de Estado com quem teria apenas relações de contrato.

Corbusier pretendia uma relação de distancia instrumental entre o intelectual autor do projeto e o Estado executor ${ }^{83}$.Nesta visão o arquiteto é o intelectual demiúrgico ,esclarecido que conduz através das suas idéias a sociedade. Como observa o autor esta não é a postura de Gropius, que vê um novo papel para as elites assumindo a tarefa de mediação cultural ,garantindo a passagem dos valores da antiga para a nova estrutura social, em termos técnicos do artesanato para a industria. É diferente a própria concepção de Estado concentrando o interesse de todos e onde se concentram os meios de intervenção.

Necessário ,porem dificil , distinguir o que são as declarações dos Congressos e o que são escritos de Le Corbusier divulgados como conclusões. Para La Sarraz ele teria levado pronto um texto que versava principalmente sobre arquitetura e que teria sido recusado pelos participantes. $O$ documento oficial seria um início de uma carta de urbanismo. Entretanto, é a versão de Corbusier a mais difundida e conhecida. A forma esquemática como se expressava pode ser responsável pela difusão ampla de suas idéias. À facilidade de exposição soma-se ao empenho em registrar e publicar .

No segundo congresso a representação amplia-se para os Estados Unidos com a participação de José Luis Sert .Organizado por Ernest May, em 1929 em Frankfurt, tinha como objeto o estudo a condição minima de existência ${ }^{84}$ As discussões se fazem a partir do estudo de uma moradia mínima analisando mais de cem projetos de

82 Benevolo, Leonardo "História da arquitectura moderna Madri , 2 vol Ed Taurus, 1963.

${ }^{83}$ Benevolo observa em Corbusier uma concepção formal de poder enquanto posse dos meios jurídicos e fínanceiros necessário para executar certos programas .Benevolo Leonardo, opus cit ,.p 476.

84 Em muitas versões será veiculado o tema como o de 'habitação mínima' o que significa uma restrição ao âmbito das discussões do congresso. 
habitações elaborados em 27 diferentes cidades .Este esforço de catalogação de informações estará presente também no $4^{\circ}$ congresso. Informações apresentadas de forma padronizada sobre 33 cidades formam a base para a Carta de Atenas.

É apenas aparente o confronto entre as diferentes metodologias de projeto de moradia.$O$ esforço em comum é dirigido no sentido da definição de um modelo de gestão urbanística, muito mais do que a sugestão de ordem tipológica ou formal ${ }^{85}$. $\mathrm{O}$ segundo e terceiro congressos são marcados pelas realizações em habitação dos governos socialistas na Alemanha e na Holanda .Estas experiências por um lado ,ampliam a problemática do vínculo entre o projeto de arquitetura e a racionalização e padronização da produção industrial ao focalizar esta relação como diretamente ligada às políticas de gestão urbana . Por outro lado ,os debates em Bruxelas demonstraram que as experiências foram parâmetro e limite, não se procurando ou propondo soluções que ultrapassassem as realizações das administrações socialistas

O significado da relação entre a arquitetura e a produção industrial teve diferentes e por isso mesmo importantes interpretações .Le Corbusier associa a possibilidade de standardização ${ }^{86}$ à produção em massa : a multiplicação de elementos construtivos tornaria a construção da moradia mais barata ,e portanto mais acessível .

Os arquitetos alemães atribuíam à possibilidade de uma racionalização da produção de moradia , a transferência de atividades que se davam, de forma privada no interior da habitação, para o espaço público em equipamentos de uso comunitário ${ }^{87}$ Esta transferência teria o importante papel de liberar a mulher do trabalho doméstico e possibilitar a inserção no mercado de trabalho. Lucio Costa confere um significado de mudança à estas teses, porém adaptadas ao contexto da sociedade no Brasil “A casa

85 Tafuri aponta os limites da cultura arquitetônica do CIAM ao propor a continuidade absoluta entre a produção em série e a construção das cidades. "Seguindo os debates do CIAM poderia se crer que a natureza da cidade foi identificada à do patrimônio imobiliário. Uma vez que é assegurado o controle dos modos de formação e produção deste patrimônio se detém a chave para planejar o desenvolvimento."opus cit ,p211.

86 Os elementos compreendem a ossatura independente o plano e a fachada livre. O uso do ferro e cimento armado.

87 Bonduki, Nabil "Origens da habitação social no Brasil" São Paulo, ed Estação Liberdade , 1998.,p 138. 
moderna seria um instrumento de libertação dos trabalhadores .A máquina de morar ao tempo da colonia dependia do escravo (..) O negro era esgoto; era água corrente quente e fria ; era interruptor de luz e botão de campainha .As facilidades modernas diminuiriam a necessidade de empregados domésticos, que passariam a trabalhar nas industrias" ${ }^{88}$

No segundo e principalmente no terceiro congresso a problemática ampliara-se da unidade habitacional para a cidade.$O$ ponto de inflexão é o congresso de Bruxelas quando, segundo Gideon , o planejamento urbano passa a ser central nas discussões ${ }^{89}$. A partir do quarto congresso a questão do urbanismo domina os debates.

Iniciado,em 29 de julho de 1933 a bordo do navio Patris, o $4^{\circ}$ congresso foi concluido alguns dias depois em Atenas. Cem delegados durante a viagem estudaram 33 cidades ${ }^{90}$, com forte representação européia .Todas as principais cidades capitais de países da Europa estão representadas. Dos Estados Unidos destaca-se , apenas ,Los Angeles e Detroit. Não há representação de cidade da América do Sul. A representatividade procurada e relatada por Gropius nos informa sobre a percepção do papel e importância das cidades pelos arquitetos modernos: as capitais seriam as européias Paris, Londres e Berlim; os centros industriais representados pelas cidades americanas Los Angeles e Detroit; centros residenciais representadas por Hague e Estocolmo e as cidades coloniais por Dalat e Bandoing

O material de estudo foi apresentado em uma cartografia uniformizada para a comparação : dois mapas na escala 1: 10 000; um documentando residências, atividades produtivas e áreas públicas equipadas ; o outro documentando o tráfego e a

\footnotetext{
${ }^{88}$ Apud Cavalcanti 1987 in Bonduki, 1998,opus cit, p 139

${ }^{89}$ Conforme .Gideon, sinalizando esta mudança é eleito presidente do CIAM Cornel Van Eesteren, chefe do departamento de planejamento urbano de Amsterdam, in Sert ,opus cit $p$ IX.

90 Conforme Benevolo ,as cidades estudadas foram : Amsterdam, Atenas, Bruxelas, Baltimore, Bandung, Budapest, Berlin, Barcelona , Charleroi, Colonia, Como, Dalat, Detroit, Dessau, Frankfurt, Genebra, Genova, La Haya, Los Angeles, Littoria, Londres, Madri, Oslo, Paris, Praga, Roma, Rotterdam ,Estocolmo, Utrech ,Verona, Varsovia, Zagreb, Zurich . Benevolo, Leonardo "Historia da Arquitetura Moderna"vol 2 Madri, Taurus Ediciones, 1963, p 601 .
} 
rede viária e um mapa em escala $1: 50000 \mathrm{com}$ o entomo imediato à cidade representando as ligações suburbanas e as características de relevo e paisagem.

A carta de Atenas é estruturada em capítulos subdivididos em duas partes : uma descrevendo de forma crítica o estado atual das cidades e outra prescrevendo o que fazer. $\ddot{E}$ um documento que tem uma enorme capacidade de divulgação - as mais opostas correntes urbanísticas, com posições políticas diferentes identificam seus princípios na Carta de Atenas .Esta capacidade de penetração deve-se a uma conjugação de fatores: sob o ponto de vista político está ausente o caráter propositivo e reformador do primeiro e segundo congressos, em favor de uma neutralidade resultante de um consenso redutor. Sob o ponto de vista urbanístico os princípios são de caráter tão genérico que podem ser adotados tanto como uma intervenção de regulação na cidade existente como propostas planejadas para uma nova cidade. Correntes urbanísticas diferentes percebem-se como tributárias dos princípios da Carta de Atenas Por exemplo, os princípios podem ser interpretados tanto como a indicação para o zoneamento monofuncional como por zonas polifuncionais na tradição do zoning alemão; a hierarquização do sistema viário tanto separa por tipo de circulação, como apenas classifica velocidades e larguras de vias.

A leitura das duas versões- a que é publicada pela primeira vez em 1941 pelo grupo CIAM França coordenado por Le Corbusier e a de José Luis Sert "Can our cities survive?"91 são muito semelhantes no texto.Porem, a comparação mais interessante pode ser feita entre o texto e as ilustrações da "Ville Radieuse" "pablicada no mesmo ano do congresso e as ilustrações ao texto da Casta no livro de Sert.

A cidade idealizada por Corbusier é uma totalidade ${ }^{93}$, uma cidade pensada a partir de

91 José Luis Sert "Can our cities survive ? an abc of urban problems, their analysis, their solutions based on the proposals formulates by the CIAM" Cambridge, Harvard Press, 1944. 92 Le Corbusier "La ville radieuse elements d'une doctrine d'urbanisme pour l'equipement de la civilisation machiniste"Paris , Ed Vincent , Fréal\& Cie, [1933], 1964.

93 'É questão de criar 'la ville radieuse'. Ela está no papel. Assim que uma obra da técnica é desenhada(números e desenhos) ela existe.A certeza está na execução apenas para os espectadores .A ' ville radieuse'que dissipará nossa angustia que sucederá ao crepúsculo ela existe no papel.Esperamos um 'sim'de uma autoridade que a queira e que vele por ela" $L e$ Corbusier, 1964,opus cit, p 92. 
um plano. Esta cidade grande, cidade capital é menos expandida porque mais densa Ela não tem suburbio. Corrigindo o paradoxo proposto na cidade contemporânea para 3 milhões de habitantes ,exposta em 1922 , não existe cidade -jardim , segundo ele "uma utopia pré maquinista" Nesta cidade as grandes densidades, três a seis vezes maior do que o existente nas cidades, garantem a viabilidade financeira do empreendimento. $O$ pedestre nunca encontra o veículo .0 solo é livre para o pedestre , desaparece a concepção de rua ,o esporte, o espaço livre toma conta da cidade. É uma cidade verde e ensolarada.

As palavras de ordem desta nova ordem urbana:

Viver (respirar) -é necessário sup rimir o subúrbio, colocar a natureza no interior da cidade.

Viver (habitar)é necessário organizar o mundo moderno, equipar a sociedade. A era maquinista liberando o homem, menos horas de trabalho, mais horas de lazer.

Morte à rua: hierarquia das velocidades; sem cruzamentos

Descartes era americano? Razão de ser do arranha céu.

Uma nova cidade substitue a antiga cidade- "la ville radieuse"

O elemento biológico a célula de $14 \mathrm{~m} 2$ por habitante.

As pranchas que ilustram este manifesto, terminado em 1931, mostram que com a edificação escalonada ( en redent) a rua corredor desaparece ; a densidade preconizada é de 1000 habitantes por hectare ; a hierarquia é elemento de separação da circulação : no solo o pedestre, ruas sobre pilotis 5 metros acima do solo para circulação dos automóveis, elevadores para o serviço publico, o teto jardim ; a unidade de vizinhança equipada com creche, escola pré primaria e primária e no centro de negócios os arranha céus; as industrias leves servidas por ferrovia e transporte rodoviário.

Os capítulos do livro de Sert que precedem a Carta por outro lado consistem em uma versão abrandada dos princípios.Ausentes as palavras de ordem de Corbusier .Sem uma visão radical de uma nova ordem urbana, fornece os elementos para intervir na cidade existente, através por exemplo do zoneamemto, destaca os elementos que compõem a totalidade idealizada por Corbusier e os adiciona à cidade existente . 
Sert inicia com "habitar - primeira função humana" e aborda o tema da congestão das grandes cidades nos Estados Unidos e na Europa, as áreas degradadas e os cortiços. Contra a localização arbitrária da habitação ele propõe ,tanto, o controle com um discurso favorável à legislação de zoneamento, como o planejamento de novas áreas habitacionais. A habitação, organizada em unidades de vizinhança ,com limite de densidade, dependeria de uma localização adequada tendo em vista clima, solo, meio ambiente. A imagem que ilustra esta descrição é de um conjunto habitacional planejado na cidade de Barcelona.

O segundo tema é a área verde .Não avança muito na discussão deste tema .Alem de mostrar a escassez e preconizar a substituição-via demolição - de cortiços por áreas verdes ele aborda o lazer de fim de semana mostrando o congestionamento das praias.

O trabalho, terceiro tema abordado, apresenta ,como a habitação, o problema da localização. Identifica os elementos que influenciam a escolha da localização, utilizando a teoria clássica de localização industrial : acesso a matéria prima, mão de obra, transporte, acessibilidade ao mercado, recursos financeiros. A industria é a atividade econômica estudada. A redistribuição preconizada é a criação de distritos industriais.

$\mathrm{Na}$ questão do transporte está a principal diferença propositiva entre Sert e Corbusier. Concordam no diagnóstico - o congestionamento, a escassez de áreas de estacionamento, a crítica aos traçados para criação de grandes visuais e localização de monumentos .Porem o traçado viário resultante, para Corbusier, quando hierarquizado separa setores da cidade definidos por funções urbanas .Para Sert ,como ilustrado no livro, a hierarquia viária é obtida pelas grandes obras de cruzamentos em diferentes niveis resultando nas estruturas viárias que dominam as cidades no pós guerra com grandes viadutos e rotatórias.

A comparação entre as duas obras permite apontar algumas precisões quanto a origem e a circulação de idéias. Os princípios da Carta de Atenas tem sua origem na obra de Corbusier , porem, como resultado de um consenso, é muito menos radical sob o ponto de vista urbanístico. Nesse sentido o que é muitas vezes interpretado como 
tributário da Carta é na realidade uma proposta adaptada dos ideais corbusianos de uma nova cidade. O plano piloto de Lucio Costa para Brasilia é o melhor exemplo.

Scherer observa na introdução à publicação da $\mathrm{Carta}^{94}$ "Na Carta de Atenas o Estado e a administração pública são vistos como elementos neutros, voltados para a consecução do bem comum, que devidamente informados, pautariam sua ação pela suposta racionalidade inerente ao conhecimento técnico e científico. Esta perspectiva deixa de lado tanto o acesso preferencial que as classes dominantes têm do poder do Estado, quanto aos grupos de poder constituídos no interior do próprio aparelho estatal."

Esta observação das relações diferenciadas que os urbanistas presentes nos Congressos mantém com o poder do Estado podem, a nosso ver ser também importante elemento de análise das inserções sociais e políticas dos profissionais do urbanismo no Brasil.

Diferem as versões sobre as razões do hiato de dez anos entre a realização do quarto congresso e a publicação. Sert atribue apenas às inseguranças dos anos que precedem a guerra. Tafuri interpreta de forma diferente a possibilidade do consenso em torno de um documento de princípios. "Não é por acaso que a Carta de Atenas vem a luz quando as experiências de urbanismo já foram realizadas. As hipóteses que ela formula encontram eco no plano de Amsterdam elaborado por Corbusier. Trata-se entretanto de uma regressão em relação à síntese que ele havia procurado no plano Obus .Em outro fronte, a experiência dos arquitetos radicais alemães está liquidada"95. O seu principal mérito é também a sua principal fraqueza - ao fornecer um modelo universal para o urbanismo moderno, ignora as diferenças, esquece as experiências sucedidas, confunde os traços.

\footnotetext{
94 Scherer, Rebecca "Apresentação" _in Le Corbusier A Carta de Atenas EDUSP Hucitec, 1986.

95 Tafuri ,Manfredo, 1991, opus cit , p 211
} 


\section{Le Corbusier e o Brasil}

Le Corbusier no Salão de Outono em 1922 expõe o projeto de uma cidade de 3 milhões de habitantes onde estão presentes os elementos de intensificação da vida moderna proporcionada pela metrópole: o trabalho correspondendo à posição central dos negócios na cidade, a velocidade da circulação hierarquizada, a alta densidade, o solo livre ,a altura dos edifícios .A organização rígida e ortogonal dos espaços de trabalho, a repetição da tipologia em reentrância dos edificios são elementos estruturadores da proposta. Em nenhum momento, a reforma ou a nostalgia pelo passado. Na proposta para o centro de Paris -Plan Voisin-plano para redimir o papel do automóvel - a cirurgia é indicada. No lugar da tipologia de quadras fechadas de seis pavimentos definida desde a reforma de Haussmann no século XIX ele propõe os altos arranha céus deixando o solo livre .

Nos planos para as cidades na América do Sul: São Paulo, Rio de Janeiro, Buenos Aires e Montevideo a solução se faz sob o mesmo princípio do elemento que se repete e estrutura o espaço. Sobre a cidade existente, congestionada, aprisionada pela topografia, apertada junto ao mar ele cria novos espaços artificiais, projeta grandes estruturas que pousam sobre as cidades existentes. Nada de reformas ou de acertos .

Como observa Martins ${ }^{96}$ o diagnóstico sobre a situação de Buenos Aires embora impreciso e pouco técnico serve, porém, para a afirmação de sua tese dando ênfase aos problemas que considera fundamentais : $a$ inadequação do traçado à circulação motorizada à velocidade que deve caracterizar a cidade contemporânea, ao posto de comando da civilização maquinista e a perda de contato vital entre o habitante da cidade e a natureza.

Estabelecendo relações com a posição geográfica, com a natureza ele projeta para

\footnotetext{
96 Martins, Carlos Alberto Ferreira "Le Corbusier en la conquista de America: ciudad y paisaje en los proyectos sudamericanos y el embate contra el SFU"in Seminário Internacional As origens das Políticas modernas na América Latina 1900-1945 IPPUR, Rio de Janeiro, agosto/setembro 1994.
} 
Buenos Aires uma grande plataforma sobre o rio, onde se localizam torres de negócios Ocupando $5 \%$ do solo e reservando $95 \%$ para a circulação e estacionamento de automóveis, articulando a localização, também em plataforma, de um novo aeroporto, ele está, com nova proposta formal reafirmando o principio já expresso no projeto de cidade contemporânea de 1922, a convergência de todas as formas de comunicação e circulação para o centro de negócios.

Para São Paulo ele projeta eixos que se cruzam e pousam sobre morros e vales .0 plano Obus para Alger retoma a essência das soluções propostas para o Rio e São Paulo.

Na conferência que faz na Associação dos Arquitetos no Rio de Janeiro, em 8 de dezembro de 1929 , Le Corbusier descreve as propostas desenhadas para São Paulo depois de sobrevoar a cidade e percorre-la de carro: "Propus o seguinte para os meus amigos de São Paulo. A origem destas estradas que se encontram no centro vem de muito longe Santos, Rio de Janeiro. $O$ diâmetro urbano da cidade é muito alargado: 45 quilômetros. Vocês constroem auto estradas; por enquanto, estando coladas ao solo , elas sofrem a sua influencia. Se fizéssemos isso : construir, de colina a colina de pico a pico, uma régua horizontal de 45 quilômetros, depois uma segunda em angulo quase reto para servir os outros pontos cardeais.(.)Vocês não sobrevoarão a cidade de carro, mas sobre rodarão. Estas auto estradas que lhes proponho são viadutos gigantescos. Não façam arcos onerosos para sustentar seus viadutos, construam-nos sobre estruturas de concreto armado que constituirão escritórios no centro da cidade e habitações na periferia .0 volume desses escritórios e dessas habitações será imenso, de acordo com o espirito do tempo trata-se portanto de uma magnífica valorização ,Um projeto preciso, um edital .Operação já descrita(..)Para vencer as sinuosidades do planalto acidentado de São Paulo, pode se construir as auto estradas em nivel, sustentadas por "arranha terras"

Em 1936 Corbusier retorna e permanece um mês entre julho e agosto no Rio de Janeiro . Profere seis conferencias na Escola Nacional de Musica e, mais importante,

${ }^{97}$ Santos Cecilia Rodrigues et alt , opus cit ,pp 92,93 
dirige dois ateliers, um para o projeto do edifício do Ministério da Educação e Cultura, outro para o projeto da Cidade Universitária., quando trabalha com Lucio Costa, Oscar Niemeyer e Affonso Reidy. ${ }^{98}$

A associação de Corbusier com o governo de Vichy no periodo da ocupação alemã na França é mostra da ambiguidade das suas posições politicas. A ansiedade em ver seus projetos realizados Corbusier faz contatos e apela para amigos. Desta forma vem ao Brasil na esperança de projetar Planaltina , a nova capital de que havia ouvido falar através de Blaise de Cendrars.

\section{A criação das Faculdades de Arquitetura e Urbanismo: um ponto de inflexão.}

Ficher identifica na organização do Departamento São Paulo do Instituto de Arquitetos do Brasil , em novembro de 1943, o início do movimento de autonomização da arquitetura em relação à engenharia , já dentro do contexto da arquitetura moderna. ${ }^{99}$

A arregimentação de arquitetos se fez entre os considerados "de vanguarda" ${ }^{100}$ e que aderiam aos princípios do Movimento Modemo .0 vínculo com as vanguardas artísticas é constituinte do movimento moderno na arquitetura e urbanismo. Segundo Tafuri,o melhor exemplo de integração da arquitetura às vanguardas pode ser observado através do grupo holandês $D e$ Stjil :a decomposição e recomposição de superficies e de elementos singulares na obra de Rietveld é exemplar neste sentido.

Ficher observa, também, que desde o início dominava uma clara tendência política de

98 O objetivo desta viagem é controverso e cheio de mal entendidos .Para descrição ver Santos Cecilia Rodrigues et alt opus cit, pp 106-112.

99 "No $5^{\circ}$ Congresso Pan Americano de Arquitetos reunido em Montevideu de 4 a 9 de março de 1940 surgiu uma articulação entre os arquitetos do Instituto de Arquitetos do Brasil , IAB, e o arquiteto Eduardo Kneese de Mello para organizar a sucursal daquela entidade em São Paulo"Ficher, Sylvia, opus cit , p 423

100 "Os arquitetos modernos em São Paulo formavam um grupo ligado aos artistas plásticos , como Portinari, Di Cavalcanti, Volpi , Bonadei, Rebolo, etc...Estes eram Warchavchik, Flávio de Carvalho, Rino, Artigas, Kneese de Mello, Ruchti, Bratke, Zenon Lotufo e Ciampaglia; depois vieram salvador Candia, Plinio Croce, Aflalo e carlos Milan"Forte, 1985, p 2 apud Ficher, Sylvia, opus cit, p 424 
esquerda e a defesa de movimentos nacionalistas e pela democracia. Uma das primeiras realizações da nova associação foi o $1^{\circ}$ Congresso Brasileiro de Arquitetos, em 1945 , onde dominou a campanha pelo fim da ditadura e pela redemocratização do pais $^{101}$.

A defesa do projeto, do reconhecimento da paternidade do projeto, constituía ponto programático do IAB.

Quatro eram os mercados de trabalho para o engenheiro- arquiteto, segundo o diretor do curso de engenheiro arquiteto do Mackenzie, Christiano Stockler das Neves ${ }^{102}$ : "o emprego público, onde se vai fossilizar, na maioria das vezes e padecer as torturas do regime da hierarquia burocrática, percebendo uma ridicula remuneração, inferior, muitas vezes a de um carpinteiro, chauffer ou maquinista; o emprego particular, no qual a situação moral é melhor mas as garantias do emprego público não existem, isto é, a vitalicidade e o monte pio e o ordenado que recebe nem sempre corresponde à responsabilidade dos serviços que lhe confiam ; o empreiteiro que parece exercer independência, mas é onde mais depende e isso não só de seus auxiliares e operários mas dos proprietários e até dos burocratas, precisando uma capacidade administrativa extraordinária para defender seus interesses ; finalmente $o$ administrador, a fase ideal da profissão mas raramente adotada, cujos serviços devem ser remunerados como os do médico e do advogado".

Apesar do viés da argumentação, privilegiando claramente o projeto e a inserção do arquiteto, como profissional liberal, no mercado de trabalho, as quatro opções parecem dar conta das possibilidades profissionais no momento. Estava se delineando a separação entre a atividade de construção e a de projetar como uma estratégia de valorização da profissão de arquiteto. Christiano das Neves defende esta posição desde os anos 20 e Rino Levi será, segundo depoimentos de colegas contemporâneos ,o primeiro a se dedicar com exclusividade a projetos completos da execução à fiscalização .

101 Ficher, Sylvia, 1989 opus cit, p 426.

102 De re aedificatoria ,Revista de Engenharia Mackenzie São Paulo, $\mathrm{n}^{0} 48$, p 19-22, set 1928 apud Ficher,Sylvia ,1989, opus cit , p 413 
Como observa Ficher estão imbrincadas, neste momento uma estratégia de prestígio profissional, uma mudança de orientação estética em direção ao modernismo e uma reforma do ensino que permistisse caracterizar um novo profissional arquiteto. ${ }^{103}$

Como corolário desta posição, a defesa da criação de uma escola independente de arquitetura. Em 1947 é criada a Faculdade de Arquitetura Mackenzie e um ano depois, na Universidade de São Paulo, criava-se a Faculdade de Arquitetura, incluindo, por orientação de Anhaia Mello o Urbanismo, desmembrada da Escola Politecnica. ${ }^{104}$

$\mathrm{Na}$ Escola Politécnica , as disciplinas para a formação do curso de engenheiro arquiteto ${ }^{105}$ eram: Desenho Arquitetonico e esboço do natural no $1^{\circ}$ ano; Desenho de Perspectiva , no $2^{\circ}$ ano ; Composição geral I e aulas de Desenho de Perspectiva e Desenho de composição geral no $3^{\circ}$ ano ; Construções civis , higiene das habitações , noções de arquitetura ; Composição geral II no $4^{\circ}$ ano e História da arquitetura, Composição geral III e urbanismo e Desenho de composição geral e modelagem no último ano.

Os professores destas disciplinas foram :Alexandre Albuquerque, até 1934, ministrando duas disciplinas : História da Arquitetura e Construções civis, higiene das habitações , noções de arquitetura, Luiz Ignácio de Anhaia Mello catedrático de Estética, Composição Geral e Urbanismo e Francisco Prestes Maia responsável até 1937 pelas aulas de Desenho de composição geral e modelagem e Desenho de Perspectiva. Foram assistentes de Anhaia Mello, José Maria da Silva Neves ,Zenon Lotufo, João Batista Vilanova Artigas e Ariosto Mila. A cadeira de Hidráulica urbana e saneamento, do curso de engenheiro civil era ministrada, até 1937 por João Florence de Ulhôa Cintra.

103 Aponta a relação entre a crescente regulação do governo federal, após a Revolução de 30 ,e as mudanças na formação e nas atividades profissionais dos engenheiros arquitetos .Em seguida à criação do Ministério da Educação e Saúde Pública e do Ministério do Trabalho, Industria e Comercio são criadas normas de defesa do diploma profissional através do Decreto Federal no 23569 de 11 de dezembro de 1933, Ficher, Sylvia, 1989 ,opus cit ,p422

104 Para uma descrição detalhada deste processo ver Ficher, Sylvia ,1989, opus cit , pp 428-435.

${ }^{105}$ Conforme pesquisa, em especial neste período nos $8^{\circ}, 9^{\circ}$ e $10^{\circ}$ regulamentos da Escola realizado por Ficher, Sylvia ,1989,opus cit, p 452 a 455. 
Segundo Ficher ${ }^{106}$, a cadeira de Composição geral II centrava-se no estudo da estética. A partir de 1951 passou a introduzir o estudo do movimento moderno estudando a obra de Corbusier e abordando os Congressos de Arquitetura Moderna .

O movimento de autonomia da arquitetura em relação a engenharia é um momento de inflexão importante .Caracteriza a constituição das duas vertentes em urbanismo: a herdeira dos estudos de engenharia e a que se constitue vinculada estreitamente à arquitetura.

$\mathrm{Na}$ Universidade de São Paulo ,a primeira vertente tem continuidade com Anhaia Mello .Responsável pela cadeira 23 de Urbanismo ${ }^{107}$, aborda nos primeiros anos da nova faculdade os temas que vinha tratando desde as conferencias proferidas no Instituto de Engenharia no final dos anos vinte .Inicia diferenciando o conceito de urbanismo do conceito de urbanização para , em seguida ,passar às questões práticas do governo da cidade : as finanças públicas , avaliação de imóveis e legislação urbanística. Avança na discussão dos serviços de utilidade pública ao tratar da questão da concessão e das formas de regulação. Esta disciplina de final do curso preparava o profissional arquiteto urbanista para elaborar planos nas diferentes escalas da regional à local.Articulado ao ensino de urbanismo Anhaia Mello organizou um centro de estudos urbanísticos, o CPEU, responsável por estudos e planos para cidades e regiões do estado de São Paulo.

Até a reforma de ensino em $1962,{ }^{108}$ o programa da disciplina segue a mesma estrutura , cada vez mais detalhada, o que a transforma em um verdadeiro manual de urbanismo e de planejamento municipal.

A definição de urbanismo apoia-se em documentos muito diferentes : a Carta de Atenas produzida no $4^{\circ} \mathrm{CIAM}$ e a Charte de l'Aménagement elaboração do

106 Ficher, opus cit p 450.

107 Conforme programas da Cadeira da FAU USP em 1952,1955, 1958 in Birkholz, Lauro , opus cit, pp $218-242$

108 Conforme Birkholz ,a cadeira é denominada urbanismo até a reforma de ensino em 1962 quando passa a ser chamada planejamento, seu conteúdo é ampliada e para a ser ministrada no $03^{\circ} 4^{\circ}$ e $5^{\circ}$. 
Movimento Economia e Humanismo. Não explicita as diferenças , não evidencia as contradições entre estes documentos enquanto ideário urbanístico e ideologia política . Não nos parece casual o rebaixamento das diferenças e os destaques que podem ser observados na introdução, assinada por Anhaia Mello, da apostila do curso que contem a tradução dos dois documentos e da Carta de Andes:

Três são os diplomas que orientam o planejamento territorial:

Carta de Atenas,

Charte de 1 'aménagement,

a Carta de los Andes

O primeiro - Carta de Atenas ( ..) abre as portas do urbanismo moderno(..)

O urbanismo, afirma a carta de Atenas, não pode se submeter às regras de um esteticismo gratuito e esterilizante mas é, por sua própria essência, de ordem funcional.

E se enumeram as funções fundamentais , cujo equilíbrio cabe ao urbanismo realizar: Habitar, Trabalhar, Recrear, Circular"

E destaca: "O primeiro preceito anunciado na Carta é este:

“a cidade é parte de um conjunto econômico, social e político que constitue a região .Não se pode abordar um problema de urbanismo sem referência constante aos elementos constitutivos da Região".

A tradução da Carta de Atenas é livre e seletiva. Destacam-se, conferindo outro significado, pontos que se somarão aos outros documentos, como, por exemplo, a ênfase nas diversas escalas de plano- do local ao nacional, na necessidade de pesquisa "cuidadosa realizada por especialistas" e na insistência da elaboração de documentos legais $^{109}$. São traduções livres dos princípios da Carta. Desta forma esses princípios se

109 Conforme Planejamento Territorial, Curso de Planejamento, Faculdade de Arquitetura e Urbanismo USP, 1971. Na apostila lê -se "É da maior urgência que cada cidade possua seu plano de urbanismo em articulação com o respectivo plano regional e com o do pais como um todo. É imprescindivel que a execução destes planos, assim em escala nacional, como na regional e municipal, seja assegurada pelos diplomas legais competentes" p 13 Este tema corresponde ao item 83 da Carta de Atenas "A cidade deve ser estudada no conjunto de sua região de influencia .Um plano de região substituirá o simples plano municipal .o limite da aglomeração será função do raio de sua ação econômica" Le Corbusier, Carta de Atenas ,São Paulo , Hucitec EDUSP , 1993. 
tomaram universais, servindo as mais diferentes tendências urbanisticas.

Solidariedade, distribuição equitativa dos recursos são os princípios do Movimento Economia e Humanismo. Não bastava identificar os diversos escalões mas de ordena$\mathrm{bs}^{10}$ "indo desde a pequena unidade básica local, até a grande unidade nacional e mesmo a supra - nacional" 111 A ordenação compreenderia da fase do inventário ao programa ou plano e execução, aproximando-se da idéia de planejamento. A participação da população é desejada, individualmente ou organizada. A Charte del 'Aménagement reflete ainda a situação do pós guerra Elaborada em La Tourette. $O$ objetivo final do ordenamento do território é a paz a justiça uma civilização humanista.

A Carta dos Andes, o terceiro documento que compõe a apostila, é formulada em um Seminário de Técnicos e Funcionários em Planejamento Urbano. No caso da introdução redigida por Anhaia Mello evidencia-se o ideário urbanístico e a filiação a determinadas correntes do urbanismo. Ele defende o controle do processo de urbanização através da adoção de políticas de descentralização urbana. Na disciplina , como o fizera desde a introdução do ensino de urbanismo na Escola Politécnica em 1927 , a difusão do modelo cidade jardim de Letchworth ,como objeto de estudo reflete ,além da opção pelo modelo cidade- jardim , a defesa do controle do crescimento da cidade através do planejamento regional

Os princípios do urbanismo modemista, não estão presentes nos anos de formação do ensino na Faculdade de Arquitetura e Urbanismo. São divulgados nos artigos publicados, em especial, por duas revistas dedicadas ao tema da arquitetura: Acrópole e Habitat.

A Revista Acrópole foi fundada em maio de 1938, por Roberto A. Corrêa de Brito, no

110 ordenar como tradução de aménagement .Como observamos anteriormente é empregado em francès da mesma forma que se usa a palavra planejamento em português. Têm significados semelhantes

111 "Charte de 1 'Aménagement"in o Planejamento Territorial Curso de Planejamento, Faculdade de Arquitetura e Urbanismo USP, 1971, p 20 
escritório do arquiteto Eduardo Kneese de $\mathrm{Mello}^{112}$.No início a revista divulgava principalmente a produção em arquitetura, publicando projetos recém construídos. A partir de 1951, com novo prop rietário e editor foram reservados espaços para textos com temas específicos, geralmente publicados em série, além de textos complementares aos projetos publicados. ${ }^{113}$.

A Revista Habitat começou a circular em outubro de 1950 e teve nomes importantes em sua direção como Lina Bo Bardi, Flávio Motta, Pietro Maria Bardi e Geraldo N. Serra.

O periódico abordou desde as artes populares até a arquitetura, sendo que neste último campo preocupou-se em enfatizar as inovações, principalmente aquelas condizentes com o ambiente sócio-cultural brasileiro. Foram publicados também textos sobre teatro, música, cinema, além de conter ensaios sobre história da arte brasileira, cujo objetivo era buscar um melhor entendimento da atualidade e fugir das eventuais classificações, que dividem o antigo do assim chamado moderno. A partir do número 25 , é dado um maior enfoque para a arquitetura e o urbanismo.

\section{O Movimento moderno na arquitetura e urbanismo em São Paulo}

A partir da criação da Faculdade, compõem o corpo docente engenheiros arquitetos como Icaro de Castro Mello e Zenon Lotufo, com obras de orientação moderna ,que haviam militado pela criação do IAB São Paulo. ${ }^{114}$. No ensino de arquitetura na nov

112 Entre 1938 e 1952, Roberto A. Corrêa de Brito, além de dono da revista, também foi seu diretor geral. Em 1953 a revista foi vendida à Max M. Gruenwald, que também foi seu diretor geral de sua posse, até o encerramento da revista em dezembro de 1971.

113 Dentre estas publicações em série, podem ser citadas:o livro "Notas sobre a Evolução da Morada Paulista", do arquiteto Luiz Saia (1957); um número especial sobre Brasília (no 256/257 em 1960).Durante cinco anos publicou mensalmente (de janeiro de 1954 a junho de 1959) o "Boletim do Instituto dos arquitetos do Brasil", Departamento de São Paulo; 114 Ícaro de Castro Mello, formado pelo Mackenzie, projetou o setor esportivo da Cidade universitária a convite de Anhaia Mello, foi professor assistente da cadeira de Pequenas Composições de 1950 a 1953 e catedrático de Grandes Composições de 1954 a 1957. Zenon Lotufo engenheiro arquiteto formado pela Escola Politécnica ensinou na Escola como assitente de Anhaia Mello desde 1938. Ingressou na FAUUSP em 1950 ministrando a disciplina Composição . Ficher identifica nos dois engenheiros uma aproximação com a corrente carioca do movimento de arquitetura moderna .Para uma biografia mais completa ver Ficher, Sylvia 1989, opus cit. 


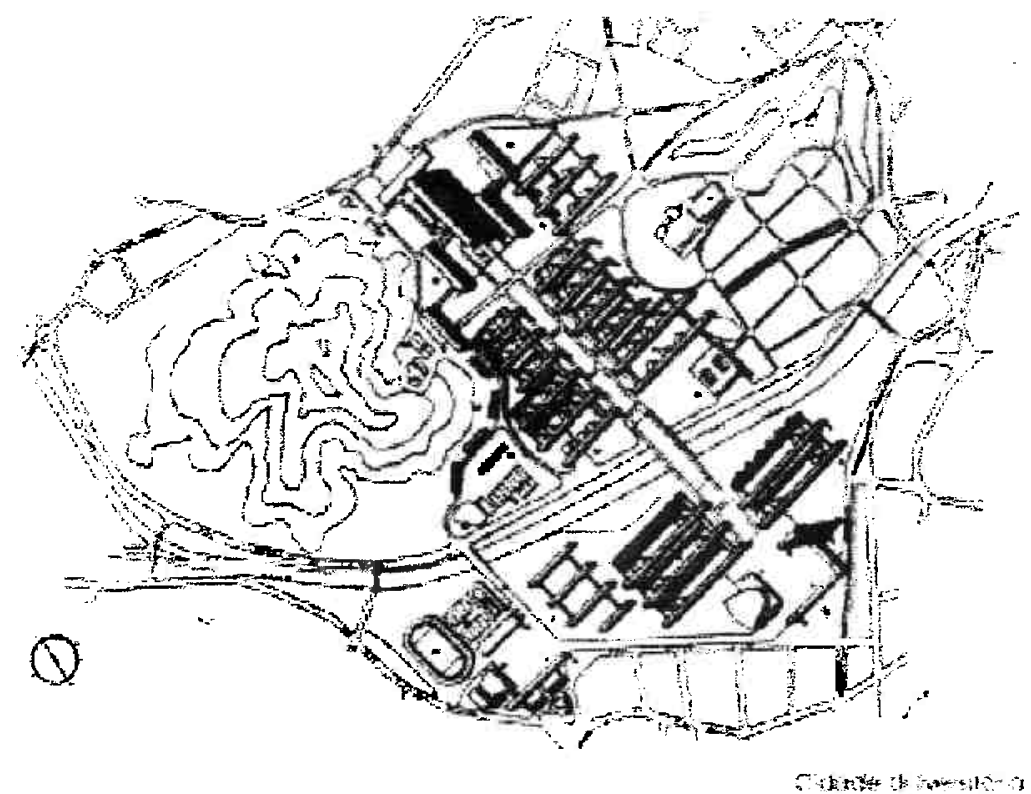

Vista geral da Cidade Universitária do Recife. Fonte: SPHAN/ Fundação Nacional Pró Memória, 1991

introduzia-se o tema da habitação social para alunos do segundo ano orientado pelos professores Vilanova Artigas e Abelardo de Souza. Tratava-se do estudo 'in loco' do problema da favela e da habitação auto construida. Incluía uma pesquisa das

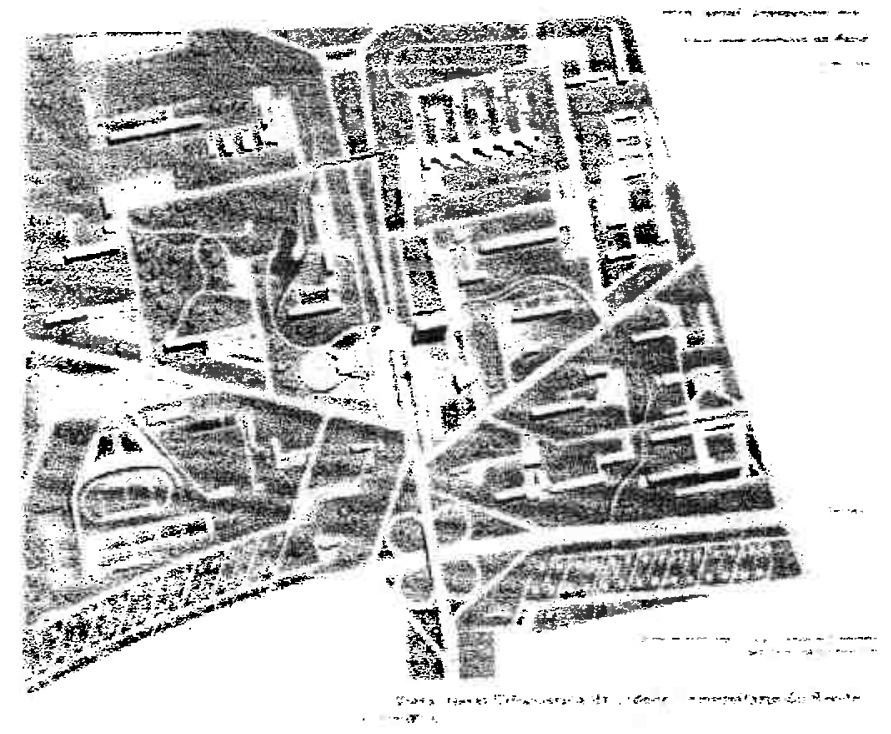

Cidade Universitária na Quinta da Boa Vista .Projeto de Lúcio Costa por solicitação do Minsitro Capanema. Fonte: Revista da Diretoria de Engenharia , maio 1937 
condições de moradia, e uma proposta de solução. ${ }^{115}$

A penetração do Movimento Moderno na produção em arquitetura e urbanismo entre os engenheiros arquitetos e arquitetos em São Paulo pode ser observada desde os anos quarenta na produção de conjuntos habitacionais dos Institutos de Previdência e em experiências mais pontuais como o plano e os projetos de edifícios para a Cidade Universitária.

Bonduki apresenta como experiências deste período a construção do Conjunto Residencial da Baixada do Carmo projetado pelo arquiteto Attílio Corrêa Lima, o Conjunto Residencial Santa Cruz projeto do arquiteto Marcial Fleury de Oliveira e o Conjunto Residencial da Mooca do arquiteto Paulo Antunes Ribeiro. Ele identifica nestes projetos a filiação aos princípios da vertente alemã do CIAM -padronização, industrialização da construção, habitação minima, pouca ou nenhuma ornamentação. No Conjunto Residencial Japurá , projeto do arquiteto Eduardo Kneese de Melo estariam presentes os princípios da Unité d 'Habitation de Corbusier : teto-jardim , pilotis, apartamento duplex , equipamentos coletivos ${ }^{116}$.

A construção de cidades universitárias acompanha a transformação de faculdades isoladas em universidades .A primeira a ser projetada, em 1936, é a do Rio de Janeiro por uma equipe formada por Lúcio Costa ,Affonso Reidy, Oscar Niemeyer e com a participação de Corbusier . Algumas das características da Cidade Universitária construída na Ilha do Fundão apontam para princípios do urbanismo modernista e aparecem também nos projetos para as universidades das cidades de Belo Horizonte, Recife, São Paulo, Vitória. O programa compreende uma grande autonomia e isolamento do conjunto em relação à cidade, além dos edifícios das faculdades são previstos conjuntos para a administração, hospital, centro de esportes, centro cultural, blocos residenciais para alunos e professores . ${ }^{117}$

115 "Dez milhões de brasileiros moram em favelas e choupana"Uma colaboração dos alunos da Faculdade de Arquitetura para a dolução do problema.Revista Habitat no 16, 1954.

116 Bonduki, Nabil , 1998, opus cit, p 182-199.

117 Ver Leme, Maria Cristina da Silva (coord), 1999, opus cit pp325-329,332-335 
Em 1945 é formada uma comissão para estudos da Cidade Universitária de São Paulo. Anhaia Mello, que havia trabalhado no levantamento do programa de necessidades da Politécnica para sua instalação na Cidade Universitária, a partir de 1945 presidiu a Comissão até sua dissolução em 1948 e a formação, no mesmo ano, da Comissão do Plano da Execução da Cidade Universitária, assumindo tam bem a presidência desta comissão até 1951 .

Consideramos, porém, que o momento de inflexão na produção urbanística é o concurso do Plano Piloto de Brasilia em 1956. Vinte e seis equipes apresentaram projetos, todos, sem excessão, segundo Ficher, exemplos do urbanismo modernista.. ${ }^{118}$ Esta vertente não pode ser atribuída aos termos do edital do concurso genéricos o suficiente para possibilitar que diferentes vertentes urbanísticas se apresentassem $^{119}$.As experiências anteriores em projeto de novas cidades haviam

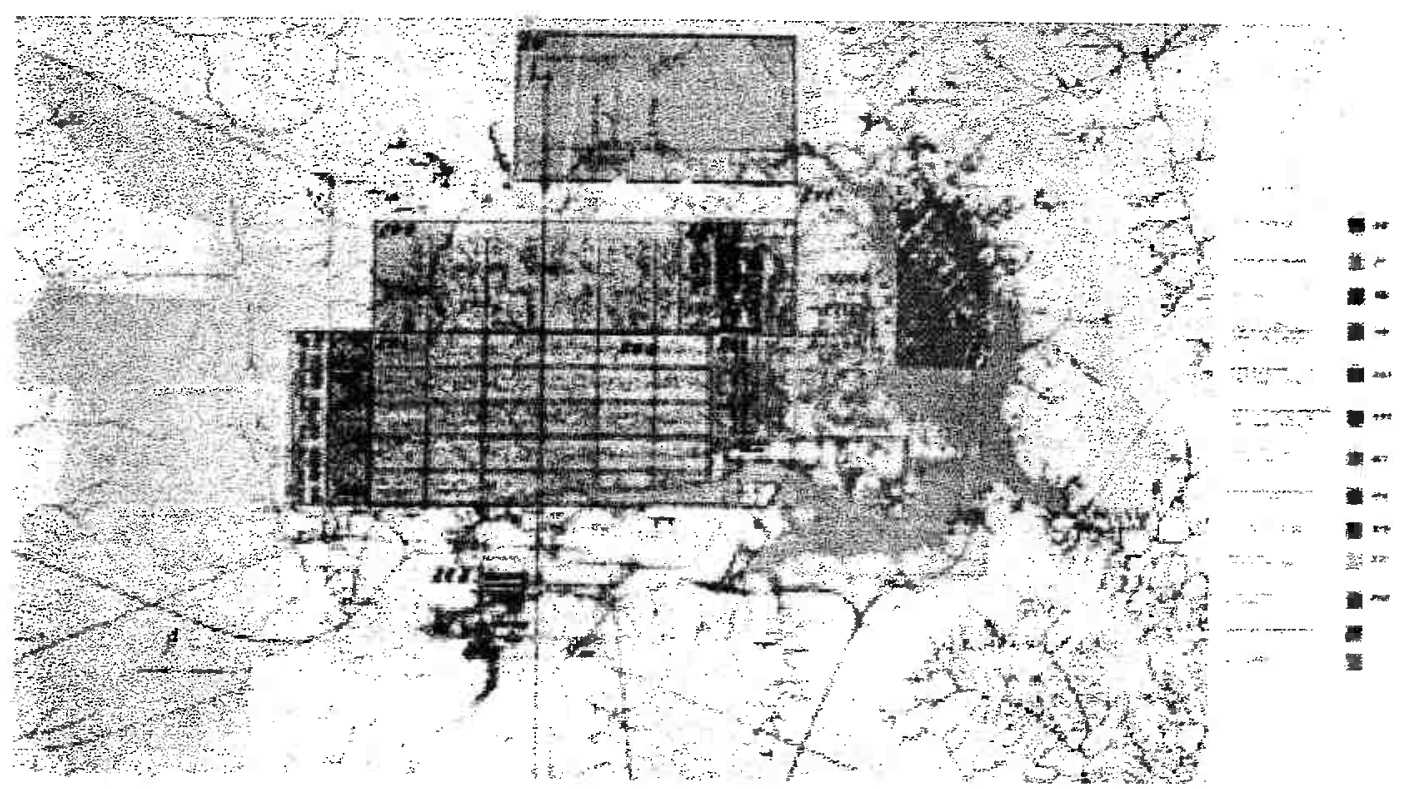

Plano Piloto Brasília . Zoneamento urbano . Equipe João Vilanova Artigas ..Fonte Revista Módulo julho 1957.

118 Ficher, Sylvia, "Brasilia e seu plano piloto"in Leme, Maria Cristina da Silva (coord), 1999, p230-239.

119 "O plano piloto deverá abranger: a)traçado básico de cidade, indicando a disposição dos principais elementos da estrutura urbana, a localização e interligação dos diversos setores, centros, instalações e serviços, distribuição dos espaços livres e vias de comunicação b)relatónio explicativo". In Revista Módub, $\mathrm{n}^{\circ} 8$ julho de 1957 , p 9 


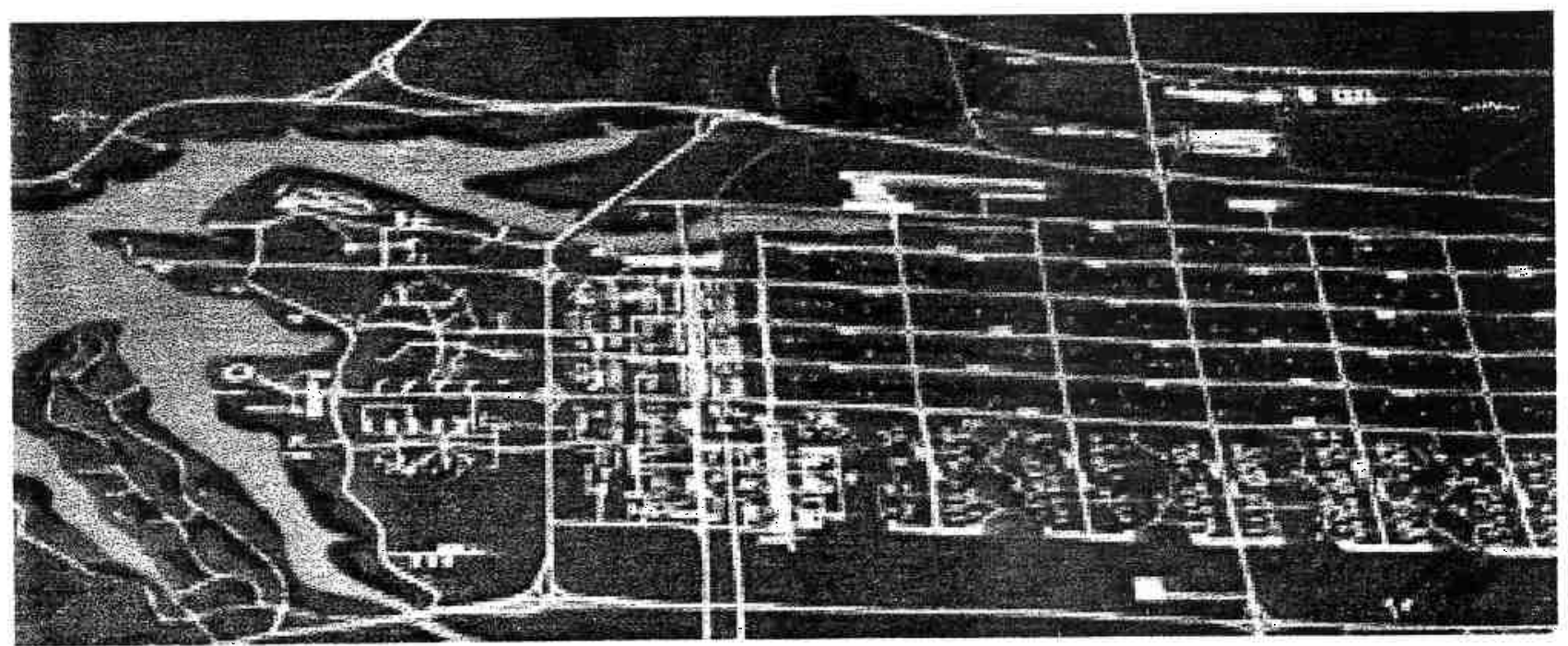

Plano Piloto Brasilia. Vista aérea da cidade. Equipe João Vilanova Artigas. Fonte Revista Módulo, julho 1957

utilizado um repertório urbanístico distante do Movimento moderno. Predominavam as soluções que tinham como paradigma o repertório mais divulgado do modelo cidade jardim: traçado viário adaptado à topografia ,uso da solução viária em cul de sac, espaços livres internos às quadras ${ }^{120}$.

Na reflexão de Artigas, em 1965, respondendo sobre a falência do movimento funcionalista é possivel perceber as expectativas e os limites da adesão ao movimento moderno. "O funcionalismo tinha um programa ,um projeto para colocar a arquitetura a serviço de sua própria "desalienação" como também a serviço do esforço geral da cultura, na transformação do homem. Não pode e não poderia cumprí-lo até o fim mas, ao levá-lo a prática, concorreu para o melhor conhecimento, por parte dos arquitetos da natureza dos obstáculos a vencer." No mesmo texto, mais adiante, ele observa os vínculos entre o processo de industrialização do Brasil, naquele momento, e as teses funcionalistas "Os países subdesenvolvidos desejam a industrialização, quaisquer que sejam as suas decorrências, pois que, partindo das teses funcionalistas,

120 A influência do modelo cidade jardim pode ser observado tanto no projeto de Armando de Godoy para a na parte sul do projeto de Goiania como nas cidades de colonização no norte do Paraná. 
seria possível o seu controle, já agora para transformar o nosso mundo no qual o atraso do desenvolvimento capitalista, ou a sua convivência com o feudalismo, provoca espetáculos de miséria social muito piores."121

A proposta que a equipe de Artigas desenvolve para o plano piloto compõe-se de uma primeira e extensa parte denominada plano regional em que estuda as características de clima, insolação, vegetação, solo, mananciais e propõe um zoneamento regional e o sistema de comunicação de rodovias e ferrovias .No plano urbano parte substancial é dedicada à estimativa da futura população residente e das possibilidades de ocupação para a os operários após a construção da cidade

O Plano urbano foi organizado em "zonas perfeitamente delimitadas". O que as caracteriza não é uma norma jurídica proibitiva ou permissiva, como não é a idéia de um campo neutro a ser ocupado, por um nucleo inicial de atividade em expansão, com tonalidades mais concentradas em um ponto e diluídás nas margens. Ao contrário tratam -se de áreas interligradas, unas, é que , no seu todo, se caracterizam pelo gênero de vida que aí vai se desenvolver" "222. A recomendação sobre as etapas de construção da cidade é coerente com esta noção de partes constitutivas de um todo as zonas poderiam ser construídas por partes mas não a cidade .As zonas deveriam ser construídas em proporções que guradassem o equilíbrio do todo. São Programadas três zonas residenciais em unidades de vizinhança variando a tipologia de unidades isoladas e individuais à unidades coletivas com gabarito alto; uma zona militar, um centro cívico, uma zona de comercio e escritórios, uma zona de comercio atacadista, e três zonas verdes próximas à região dos lagos. Sobre esta estrutura de zonas se soprepoe uma estrutura de rede de serviços e comercio do nivel local ao mais geral para toda a cidade.

No primeiro croquis do plano urbano são projetadas quatro macro zonas que definem

121 Artigas, Vilanova "Uma falsa crise" in Caminhos da arquitetura, Ed Pini, $2^{a}$ ed, $1986 \mathrm{pp}$ 97101 .

122 Cascaldi, Carlos, Artigas, João Vilanova, Cunha, Mario Wagner Vieira, Almeida,Paulo de Camargo "Futura capital federal ,Brasilia ,Plano piloto .Relatório apresentado à Comissão julgadora do concurso para o Plano Piloto da nova capital federal"São Paulo, março 1957. 


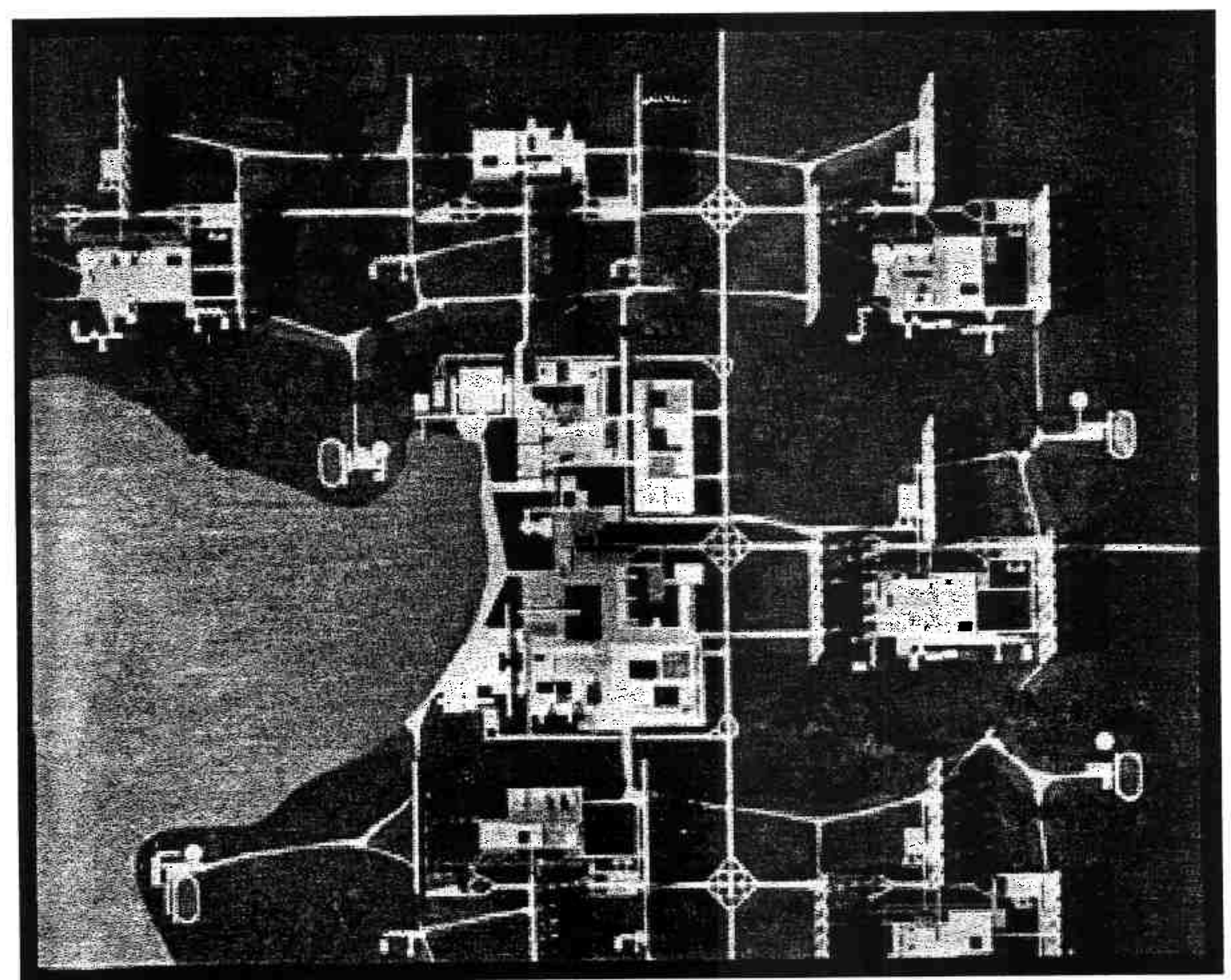

Plano Piloto de Brasília Vista geral da cidade. Equipe Rino Levi. Revista Módulo, julho 1957

a concepção do plano a parte central é ocupada por um grande retangulo contendo as unidades de vizinhança, deslocado, acima à direita um pequeno quadrado delimita o centro cívico. A zona industrial é situada à esquerda das residências e a direita a zona comercial. Junto aos lagos um parque municipal e ao sul da zona residencial a zona de comercio atacadista.

A leitura do relatório e a análise das plantas revela que foi maior a ênfase no detalhamento dos aspectos relativos ao plano regional e urbano com poucas referências à arquitetura dos edificios. 
Na proposta da equipe de Rino Levi para o concurso de Brasília ${ }^{123}$, pelo contrário,sobressai a importância conferida aos blocos de edifício no setor de habitação intensiva.

A cidade foi projetada na região plana envolvida pelo lago. $O$ centro cívico foi localizado em posição de destaque na parte central do plano. Este centro composto pelos edificios do governo federal junto com as super laminas dos blocos de habitação intensiva estruturam a cidade. A circulação é formada por um sistema de vias expressas elevadas junto aos setor de habitação intensiva voltam ao nível do solo nos prolongamentos. Os trechos elevados foram dispostos em trama ortogonal.

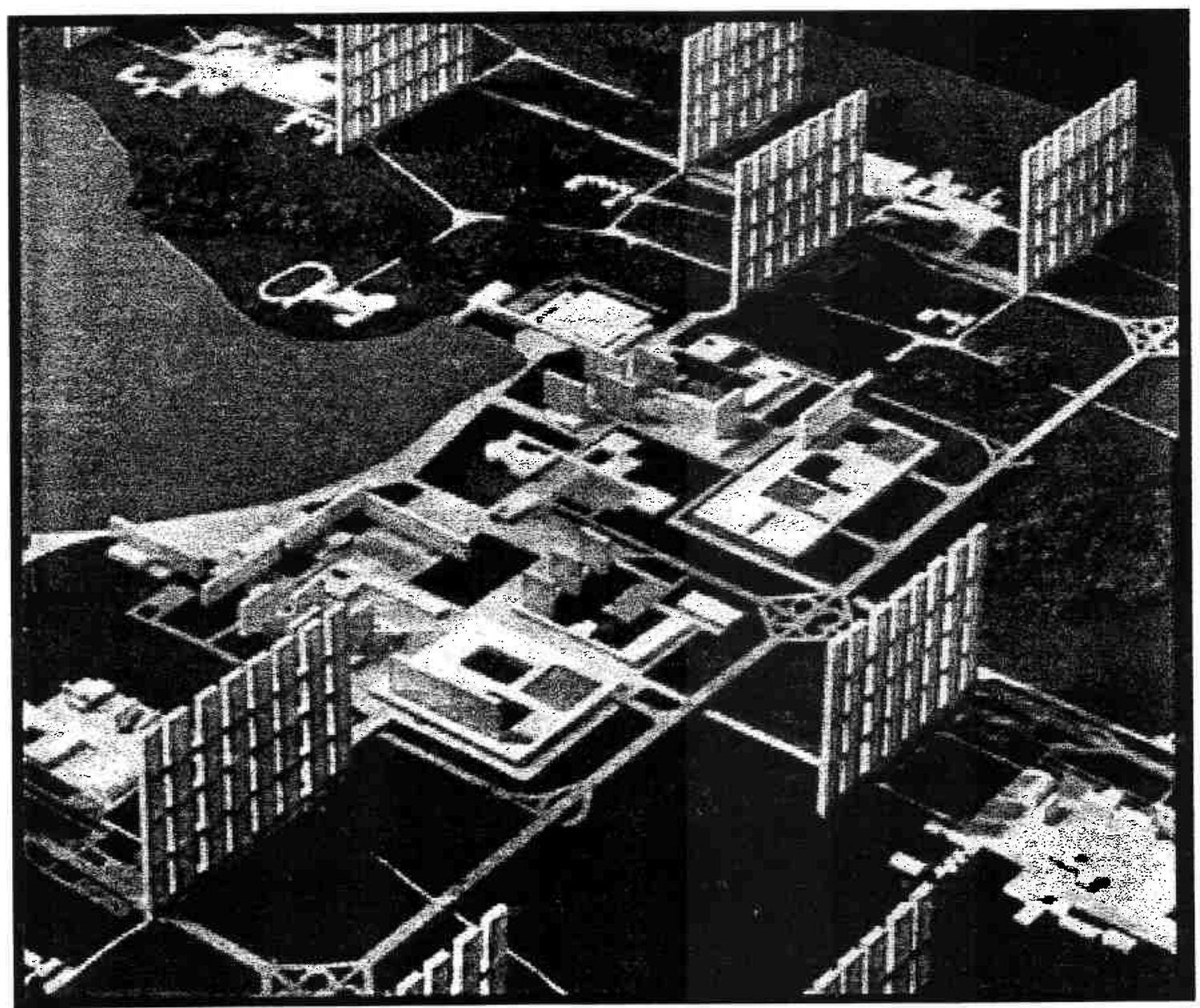

Plano Piloto de Brasília Centro cívico .Equipe Rino Levi. Revista Módulo, julho 1957

\footnotetext{
1 A equipe foi composta por Rino Lei, Roberto Cerqueira Cesar, L R Carvalho Franco, Paulo Fragoso.A proposta recebeu o $3^{\circ}$ lugar.
} 
São seis conjuntos de habitação intensiva compostas por três superblocos para 16000 pessoas cada. Dispostos ao longo das vias expressas elevadas a cada 400 metros de lados alternados. Assim a menor distancia entre blocos seria de 800 metros.

Projetados como verdadeiras unidades de vizinhança vertical, cada superbloco é composto por oito edificios, de oitenta andares cada, com 300 metros de altura Cada edificio tem dimensões de $18 \mathrm{~m}$ x 40 $\mathrm{m}$ x 60m, totalizando um bloco de $18 \mathrm{~m} \times 435 \mathrm{~m}$, com $300 \mathrm{~m}$ de altura. São acessados na extremidade pela via expressa elevada, que

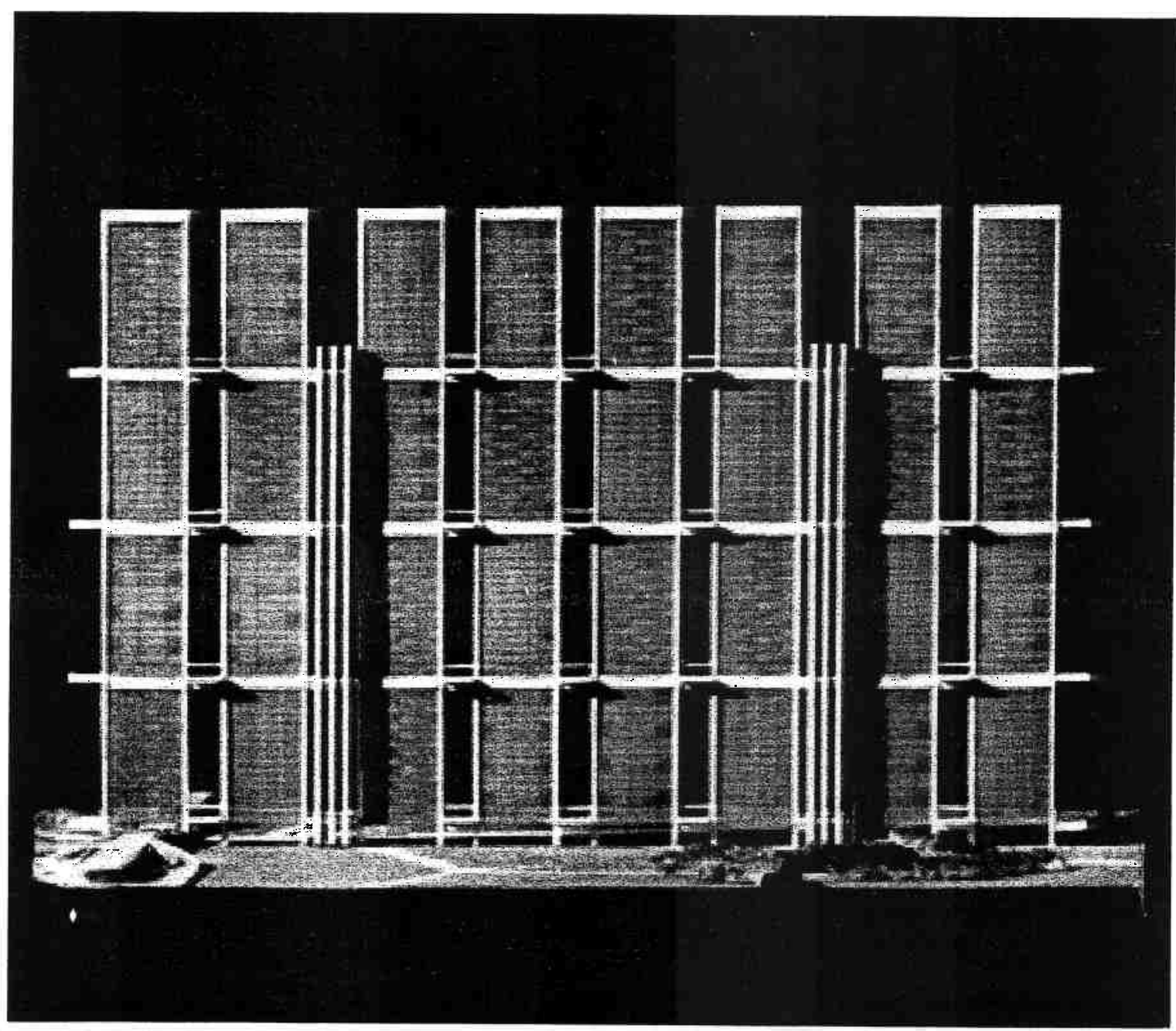

Plano Piloto de Brasilia Superbloco . Equipe Rino Levi. Revista Módulo, julho 1957 
deriva diretamente às garagens no subsolo. Uma vez acessado o superbloco, o usuário se dirige a um dos dois conjuntos de elevadores de alta capacidade que dá acesso às 4 ruas elevadas entre os blocos de edifícios e depois se dirige ao seu edifício, onde toma seu elevador convencional. Os elevadores funcionam assim como ruas verticais, inclusive hierarquizadas entre "vias expressas" e "vias locais". As ruas internas elevadas abrigam comércio local, jardim de infância, creche, posto de saúde e praças nos intervalos entre os edifícios. A estrutura dos superblocos, em aço, foi estudada em detalhes pela equipe.

Os setores de habitação semi-intensiva e extensiva se situam à beira do lago, no extremo noroeste, junto à área industrial, e nos extremos sudeste e sudoeste, também às margens do lago. Compostos por habitações individuais e edificios de apartamento nestes setores são propostos possuem um núcleo onde se situam as escolas primária e secundária, play-ground, centro comercial local, centro social e igreja . São acessados por vias secundárias partindo das vias expressas.

\section{Avanços e permanências .}

Na reflexão de Artigas, em 1965, respondendo sobre a falência do movimento funcionalista ,é possível perceber as expectativas e os limites da adesão ao movimento moderno. " $O$ funcionalismo tinha um programa, um projeto para colocar a arquitetura a serviço de sua própria "desalienação" como também a serviço do esforço geral da cultura, na transformação do homem. Não pode e não poderia cumpri-lo até o fim mas, ao levá-lo a prática, concorreu para o melhor conhecimento, por parte dos arquitetos da natureza dos obstáculos a vencer." No mesmo texto, mais adiante, ele observa os vínculos entre o processo de industrialização do Brasil, naquele momento, e as teses funcionalistas "Os países subdesenvolvidos desejam a industrialização, quaisquer que sejam as suas decorrências, pois que, partindo das teses funcionalistas, seria possivel o seu controle, já agora para transformar o nosso mundo no qual o atraso do desenvolvimento capitalista, ou a sua convivência com o feudalismo, provoca espetáculos de miséria social muito piores." 124

${ }^{124}$ Artigas, Vilanova "Uma falsa crise"in Caminhos da arquitetura,Ed Pini, 2" ed, 1986 pp 971 
No campo do planejamento urbano, nos anos que se seguem, intensifica-se a atuação dos urbanistas na elaboração de planos diretores e planos regionais.

A criação do CPEU, em 1955, por Anhaia Melo, junto à Faculdade de Arquitetura e Urbanismo representou a abertura de um novo campo profissional onde se articulava o ensino e o trabalho junto às prefeituras de cidades no Estado de São Paulo. O Centro desenvolvia atividades de assessoria para a elaboração de planos diretores mas também procurava organizar equipes locais de planejamento.

Segundo Birkholz ${ }^{125}$, o centro iniciou com planos para os municípios- estâncias hidrominerais e climáticas, obrigados por lei a terem planos diretores. Esta atuação se ampliou nos anos sessenta. Participam do CPEU, além dos professores da faculdade, pesquisadores formados nas equipes da SAGMACS, iniciando um processo de colaboração que representa a articulação das duas vertentes que haviam se formado na década anterior.

Cabe assinalar também a realização de um evento que pode ser considerado como uma continuidade e um novo patamar na propostas de reforma social veiculadas pelo Movimento Economia e Humanismo é a realização do Seminário sobre Habitação e Reforma Urbana organizado pelo IAB Instituto de Arquitetos do Brasil, com o apoio do IPASE Instituto de Pensões e Aposentadorias dos Servidores do Estado, no Hotel Quitandinha em Petrópolis no Rio de Janeiro ${ }^{126}$. No Encontro foi elaborado um projeto de reforma urbana que se pretendia que fosse incluído no conjunto mais amplo de Reformas Sociais de Base. A instauração do regime militar em março de 1964 põe fim a continuidade deste movimento.

125 Birkholz , Lauro, 1967, opus cit p 105

126 Ver sobre a influência deste evento para o planejamento urbano em São Paulo Antonucci, Denise"Plano Diretor de São Paulo 1991 Avanços e Permanências"dissertação de mestrado FAU USP , 1999 


\section{Conclusão}

O trabalho procurou mostrar a formação do urbanismo em São Paulo como campo de conhecimento e de atuação profissional desde o final do século XIX, quando se inicia uma intervenção planejada na cidade, até o ponto de inflexão representado pela configuração de duas novas vertentes, nos anos cinquenta.

A primeira vertente que vimos denominando de forma simplificada de 'urbanismo politécnico' possibilitava a dupla formação tanto nos aspectos técnicos do urbanismo como nos aspectos estéticos das composições arquitetônicas.

Na segunda vertente, o urbanismo modernista é concebido a partir da arquitetura, na relação entre o espaço edificado e o espaço livre. Como vimos a autonomização do ensino da arquitetura em relação à engenharia consolida o meio profíssional. A terceira vertente é resultado da penetração do Movimento Economia e Humanismo nos meios políticos católicos e aparece na formação dos escritórios da SAGMACS em São Paulo.

A pesar de se originarem de uma matriz comum - a transformação da cidade através da intervenção do urbanista - diferenças de ordem urbanística e de posições político ideológicas marcam a configuração destas vertentes.

A primeira tem como objetivo a reforma das estruturas urbanas herdadas de uma economia colonial. $\mathrm{O}$ urbanismo é uma atividade de previsão, de mediação e de regulação para a intervenção pública, da qual estes profissionais fazem parte.

O urbanismo modernista é marcado pela experiência da metrópole e as possibilidades de transformação radical das estruturas urbanas pré existentes. Conforme descrevemos, este movimento, na sua origem, apresenta diferentes posições político ideológicas e é marcado por fissuras e pela contradição entre as posições de Corbusier, as elaborações ideológicas das vanguardas históricas e a tradição do urbanismo moderno ${ }^{1}$.

${ }^{1}$ Tafuri, Manfredo Dal Co Francesco, 1991,opus cit, p 14 
Le Corbusier pretendia uma relação de distância instrumental entre o intelectual autor do projeto e o Estado executor Nesta visão o arquiteto é o intelectual demiúrgico ,esclarecido que conduz através das suas idéias a sociedade. Como observa Benevolo², esta não é a postura de Gropius, que vê um novo papel para as elites assumindo a tarefa de mediação cultural, garantindo a passagem dos valores da antiga para a nova estrutura social, em termos técnicos do artesanato para a indústria. É diferente a própria concepção de Estado concentrando o interesse de todos e onde se concentram os meios de intervenção.

Scherer, na introdução à publicação da Carta, alerta para a suposta neutralidade na concepção da relação de poder entre estes urbanistas e o Estado deixando de lado tanto o acesso preferencial que as classes dominantes têm do poder do Estado, quanto aos grupos de poder constituidos no interior do próprio aparelho estatal.

Os Congressos Intemacionais de Arquitetura Modema desempenham um importante papel na difusão destas idéias e experiências, ressoando de formas diferentes entre os urbanistas brasileiros.

As três vertentes não são isoladas, porém se estabelecem e legitimam em meios diferentes. Para a compreensão dos rumos que assume o urbanismo a partir dos anos sessenta é fundamental entender os pontos de aproximação e diferenças entre estas vertentes.

$\mathrm{Na}$ formação da vertente do urbanismo ligado à engenharia foi fundamental a imbricação desde o início da formação do ensino de urbanismo na Escola Politécnica e a estruturação dos quadros na Prefeitura Municipal e no Governo do Estado nos setores ligados às obras públicas. Estes engenheiros ocuparam cargos de chefia no serviço público e eram também os responsáveis pelas cátedras na escola. Esta dupla inserção reproduzia-se nos cargos diretamente subordinados e que, muitas vezes,

\footnotetext{
${ }^{2}$ Benevolo observa em Corbusier uma concepção formal de poder enquanto posse dos meios jurídicos e financeiros necessário para executar certos programas .Benevolo Leonardo, opus cit ,pp 476
} 
substituíam os titulares nos afastamentos e depois nas aposentadorias. Configura-se, desta forma, a transmissão de um conhecimento técnico e uma forma de administrar a cidade.

Salientamos duas questões na comparação entre as gerações de urbanistas que atuaram no ensino e na administração publica em São Paulo. Em primeiro lugar é a relação que estabelecem com as elites politicas e econômicas locais. A primeira e a segunda geração de urbanistas, por ocuparem os principais cargos da estrutura administrativa municipal, são responsáveis pela configuração do setor de urbanismo em temos de áreas de atuação.

Destacamos na análise da trajetória profissional destes engenheiros a relação entre o conhecimento técnico que detinham e as mudanças nas propostas de regulação e regulamentação das atividades responsáveis pela produção do espaço urbano.

A qualidade dos projetos e planos urbanísticos elaborados demonstram que estes engenheiros estavam sintonizados com os conhecimentos técnicos, os mais atualizados, em obras de infra-estrutura e serviços urbanos e detinham uma cultura urbanística onde estava presente a preocupação com o resultado estético .

Por outro lado, os limites desta atuação modernizadora na cidade são evidentes quando se analisa o âmbito e a qualidade dos projetos realizados. Observa-se que estes limites estão relacionados à forma como se manifestam os interesses privados de valorização imobiliária de partes da cidade. A imbricação de interesses destes profissionais com empresas imobiliárias e empresas concessionárias de serviços públicos marca as relações entre o poder público e a iniciativa privada nas primeiras décadas do século $\mathrm{XX}$.

Na primeira geração de engenheiros que atuam no urbanismo em São Paulo destacamos como mais significativo para analisar o primeiro período de formação do urbanismo o estudo do percurso profissional do diretor de Obras da Prefeitura Municipal, o engenheiro português Victor da Silva Freire. 
Alguns aspectos deste percurso mostram os rumos e os limites da intervenção urbanística do período. A partir de uma crítica às 'idéias feitas' que haviam moldado os padrões vigentes na legislação edilícia, ele propõe novos parâmetros para a legislação urbanística atualizados aos conceitos de salubridade, em circulação naquele momento no circuito urbanístico internacional. Ele introduz também uma nova concepção de regulação dos serviços públicos.

Procuramos mostrar que as propostas de remodelação do sistema viário e o projeto proposto para o vale do Anhangabaú, revelam o processo de modernização da cidade, porém parcial e incompleto tanto pela escala ,envolvendo apenas a sua porção central ,como pelo aspecto formal.

A partir dos anos vinte, a palavra urbanismo se torna de uso corrente. Não designa apenas uma prática planejada de intervenção na cidade, mas pretende conceituar uma área de conhecimento. É utilizada referindo-se, inicialmente, às questões da administração e, em seguida, ao planejamento da cidade. $O$ engenheiro Luiz Ignácio de Anhaia Mello desempenha um importante papel na formação e na consolidação tanto do ensino do urbanismo como na estrutura deste setor na administração municipal Anhaia Mello no cargo de vereador de São Paulo imprime uma nova forma de atuação da Prefeitura na gestão do setor de obras viárias. Suas propostas abordam a questão dos parâmetros de projeto, em uma linha de continuidade às críticas de Victor da Silva Freire à rigidez imposta à largura e ao traçado de ruas e praças, até a necessária articulação das vias de novos loteamentos ao sistema viário existente na cidade. Defendendo a cobrança de uma taxa de melhoria imprime uma preocupação nova com os recursos financeiros para a realização de obras viárias.

Junto com a defesa da regulação e regulamentação das atividades imobiliárias e de serviços urbanos na cidade Anhaia Mello escreverá sobre urbanismo e o governo da cidade. É também uma linha consistente de argumentação que terá efeitos importantes na constituição e no papel que desempenhará o setor de urbanismo na estrutura administrativa da prefeitura de São Paulo.

Inicialmente, ele defende, inspirando-se no modelo americano de administração 
pública, a criação de comissões - instâncias intermediárias que vê como imparciais, não partidárias, nem políticas. Propõe a organização das comissões para diversos fins. Articuladoras entre o executivo e o legislativo, sem compromisso direto com o eleitorado elas garantiriam, segundo ele, a defesa do interesse público.

A partir de meados da década de quarenta a configuração do Departamento de Urbanismo assume forma mais definitiva. Abandonando a idéia de comissões desvinculadas da estrutura administrativa da prefeitura, Anhaia Mello advoga a criação do departamento diretamente vinculado ao prefeito e fora da rotina administrativa .

Esta forma de conceber o planejamento urbano 'fora da rotina administrativa' tem conseqüências na forma como se separam gradativamente as atividades ligadas ao zoneamento e ao planejamento da cidade. Por um lado, na prefeitura de São Paulo, compondo os quadros do Departamento de Urbanismo, como demonstra Feldman ${ }^{3}$, um pequeno grupo de engenheiros civis e arquitetos, inicia a construção da legislação de zoneamento de São Paulo. Esta elaboração, como ela observa, se fará em resposta a demandas de interesses pontuais de proteção de qualidade ambiental e de valores imobiliários no quadrante sudoeste, a parte mais valorizada da cidade de São Paulo.

O saber desenvolvido nesta atividade de proposição legislativa toma-se gradativamente um saber codificado entendido e decifrado por poucos. Em um período de abertura democrática em que acontece com alguma freqüência a substituição de prefeitos, sendo a prefeitura de São Paulo um patamar para alcançar outros cargos políticos, este grupo, estável, permanece alheio a estas mudanças. Feldman mostra também que o trabalho se realiza "no gabinete" sem nenhuma forma de respaldo político, nem da Câmara, nem de outros setores da população. ${ }^{4}$

Trata-se tanto em São Paulo como em outras cidades brasileiras do que denominamos

\footnotetext{
3 Feldman, Sarah "Planejamento e zoneamento 1947-1972" tese de doutorado FAU USP ,1996.

${ }^{4}$ São duas as constatações importantes da autora: por um lado ao demonstrar que o processo de construção do zoneamento se inicia no pos guerra, momento de grande crescimento de São Paulo e não como muitos entendiam no final dos anos sessenta.Associava-se o caráter tecnocratico da forma como foi aprovada a lei de zoneamento, sem debate,ao período político autoritário por que passava o Brasil.Este é o outro mito que é desfeito pela autora
} 
a terceira geração de urbanistas .Formados pelas Escolas de Engenharia, ocupam de forma permanente os quadros de urbanismo das prefeituras. Os novos engenheiros municipais têm uma ação mais restrita ao âmbito da Prefeitura sem vínculos com o ensino.

Nos escritos dos engenheiros Francisco Prestes Maia e João Florence de Ulhôa Cintra pode se observar, também, indicações da influência que começam a exercer no urbanismo paulista as idéias de urbanistas americanos. A mais importante é a introdução de princípios de racionalidade e eficiência na administração pública. Critérios como a efíciência e a eficácia dos planos urbanos passam a ser passiveis de averiguação.

Em uma linha de argumentação diferente da proposta por Anhaia Mello, defendem um espaço profissional para o engenheiro na administração municipal .Mas, segundo este ponto de vista, ao garantirem um espaço profissional reduzem o papel do engenheiro municipal ao controle e operacionalização de obras públicas. Nesta perspectiva, o casamento é perfeito, ninguém melhor que o engenheiro para ser o responsável pela administração da cidade.

Em uma linha de intervenção centrada na questão viária os textos escritos em coautoria por Ulhôa Cintra e Prestes Maia representam o momento de transição entre as idéias de Victor da Silva Freire e o novo modelo urbanístico adotado para a cidade.

Sob o ponto de vista das propostas de remodelação do sistema viário a adoção do esquema combinando as propostas de Eugène Hénard às de Joseph Stubben apontam para uma intervenção muito mais radical no tecido urbano, um rompimento com a tradição de adaptação ao traçado histórico das cidades preconizado por Camillo Sitte e adotado por Victor Freire no seu projeto para a área central.

A concepção de cidade, implícita nas propostas do Plano de Avenidas de ocupação extensiva do solo estruturada por um sistema viário radial-perimetral, corresponde a nível da estrutura urbana por um lado ao novo padrão de ocupação periférico da cidade e, por outro lado, garante uma integração mais eficiente entre os diferentes 
bairros e o centro da cidade. Prepara-se dessa forma uma estrutura urbana mais integrada e homogênea, condições necessárias à expansão do processo de industrialização que ocorrerá na próxima década.

A experiência de São Paulo não é isolada. Nos anos trinta e quarenta serão elaborados planos para um grande número de cidades brasileiras propondo a remodelação do sistema viário ${ }^{5}$. Na comparação destes documentos constata-se alguns pontos em comum: o modelo radial - perimetral e a presença de sistemas de parques e jardins.

O plano de melhoramentos elaborado pelo IIBEC, sob o ponto de vista urbanístico, pode ser considerado em uma linha de continuidade com o Plano de Avenidas, ao enfatizar mais uma vez como solução para São Paulo o transporte sobre pneus, em um sistema de vias expressas. Projetadas em trincheira atualizam para os anos cinqüenta os projetos em escala mais modesta elaborados por Prestes Maia.

Duas questões, porém, abordadas no Plano: a indicação de compra de ônibus para suprir o transporte coletivo da cidade e a proposta de formação de uma corporação com a participação da Light Tramway and Power para urbanizar as terras ao longo do canal do Rio Pinheiros, revelam que não se tratava apenas de um plano urbanístico, mas que abria a possibilidade de um campo de negócios entre as empresas estrangeiras e a municipalidade. Evidenciam uma mudança na forma como se estruturam os interesses em torno da cidade, se comparamos aos contratos estabelecidos entre as empresas de serviços públicos e a municipalidade no início do século. Conferem um novo papel ao planejamento como suporte para formas contratuais entre empresas $\mathrm{e}$ municipalidade na produção do espaço urbano.

Também para compreender a formação da SAGMACS em São Paulo, nos parece necessário inseri-la no quadro político do após guerra. Como mostra o depoimento de Celso Lamparelli à Revista Espaço \& Debates, para os meios políticos católicos o Movimento Economia e Humanismo respondia a uma expectativa de uma via

5 ver sobre planos e conjunto elaborados neste período Leme, Maria Cristina da Silva, opus cit pp358-412 
alternativa à polarização do quadro político entre o capitalismo e o comunismo. A rede de contatos que o Padre Lebret estabelece desde o início é de grande prestígio, são quadros de direção da universidade de São Paulo e lideranças políticas católicas o que propiciou contratos para a formação dos escritórios da SAGMACS.

Para os estudos urbanos em São Paulo identificamos três importantes contribuições do método introduzido por Lebret. Em primeiro lugar, a percepção da diversidade sócio econômica na composição de bairros da cidade, associada a esta visão a compreensão da existência da periferia e de sua relação dialética com o centro tem ,a nosso ver, um enorme impacto na formulação do pensamento urbanístico em São Paulo. Derivam do conceito de desenvolvimento e sub - desenvolvimento elaborados por Lebret nos seus estudos para a América Latina. O terceiro está diretamente vinculado aos dois primeiros .É a formação de um profissional engajado tanto no conhecimento profundo de cada situação urbana como também comprometido com a sua transformação.

O movimento de autonomia do ensino de arquitetura em relação ao de engenharia é um momento de inflexão importante. Caracteriza a constituição, na Universidade ,das duas vertentes em urbanismo: a herdeira dos estudos de engenharia e a que se constitui vinculada estreitamente à arquitetura.

A primeira vertente tem continuidade com Anhaia Mello. Responsável pela cadeira de Urbanismo, aborda nos primeiros anos da nova faculdade os temas que vinha tratando desde as conferências proferidas no Instituto de Engenharia no final dos anos vinte preparando o profissional arquiteto urbanista para elaborar planos nas diferentes escalas da regional à local. Articulado ao ensino de urbanismo, ele organiza uma nova esfera de elaboração de planos, desvinculada do serviço público. Através do centro de pesquisas e estudos urbanísticos, o CPEU, professores da faculdade, alunos junto com equipes locais elaborarão até os anos setenta estudos e planos para cidades e regiões do Estado de São Paulo

Até a reforma de ensino em 1962, o programa da disciplina segue a mesma estrutura, cada vez mais detalhada, o que a transforma em um verdadeiro manual de urbanismo e 
de planejamento municipal.

Observamos porém que para o ensino de urbanismo Anhaia Mello apoia-se em documentos muito diferentes: a Carta de Atenas produzida no $4^{\circ} \mathrm{CIAM}$ e a Charte de l'Aménagement elaboração do Movimento Economia e Humanismo sem explicitar as diferenças, nem evidenciar as contradições entre estes documentos enquanto ideário urbanístico e ideologia politica.

Não nos parece casual o rebaixamento das diferenças e os destaques que podem ser observados na introdução, assinada por Anhaia Mello, da apostila do curso quando ele afirma que estes são os documentos sobre os quais de estrutura o urbanismo. Mostramos que a tradução da Carta de Atenas é livre e seletiva. Destacam-se, conferindo outro significado, pontos que se somarão aos outros documentos, como, por exemplo, a ênfase nas diversas escalas de plano- do local ao nacional, na necessidade de pesquisa -cuidadosa realizada por especialistas- e a insistência da elaboração de documentos legais .Constituem-se em traduções livres dos princípios da Carta de Atenas que, desta forma, se tornaram universais, servindo às mais diferentes tendências urbanísticas.

Da mesma forma nos detivemos no estudo de duas versões da Carta de Atenas, a atribuida a Le Corbusier e a publicada por José Luis Sert procurando esclarecer alguns dos elementos que explicariam a constatação de uma adesão declarada aos princípios da Carta por profissionais vinculados a diferentes correntes de pensamento urbanístico.

Constatamos que os textos das duas versões são muito semelhantes o que reforça o argumento da procura de um consenso como resultado do Congresso. Entretanto ao compararmos as ilustrações da "Ville Radieuse" de Corbusier, onde estão presentes os princípios do congresso e as ilustrações ao texto da Carta no livro de Sert observamos diferenças importantes.

A cidade idealizada por Corbusier é uma totalidade, uma cidade pensada a partir de um plano. Esta cidade grande, cidade capital é menos expandida porque mais densa. 
Ela não tem subúrbio. Corrigindo o paradoxo proposto no seu projeto para a cidade contemporânea para 3 milhões de habitantes, exposta em 1922, não existe cidade jardim, segundo ele "uma utopia pré maquinista". Nesta cidade as grandes densidades, três a seis vezes maior do que o existente nas cidades, garantem a viabilidade financeira do empreendimento. $O$ pedestre nunca encontra o veículo. $O$ solo é livre para o pedestre, desaparece a concepção de rua , o espaço livre toma conta da cidade. É uma cidade verde e ensolarada.

As pranchas que ilustram este manifesto, terminado em 1931, mostram que com a edificação escalonada ( en redent) a rua corredor desaparece; a densidade preconizada é de 1000 habitantes por hectare; a hierarquia é elemento de separação da circulação: No solo o pedestre, ruas sobre pilotis 5 metros acima do solo para circulação dos automóveis, elevadores para o serviço publico, o teto jardim; a unidade de vizinhança equipada com creche, escola pré primaria e primária e no centro de negócios os arranha céus; as indústrias leves servidas por ferrovia e transporte rodoviário.

Os capítulos do livro de Sert que precedem a Carta, por outro lado, consistem em uma versão abrandada dos princípios. Ausentes as palavras de ordem de Corbusier. Sem uma visão radical de uma nova ordem urbana, fornece os elementos para intervir na cidade existente, destaca os elementos que compõem a totalidade idealizada por Corbusier e os adiciona à cidade existente. Nos exemplos e nas fotos que ilustram o texto estão presentes os elementos que irão estar presentes nas cidades no pós guerra.

Contra a localização arbitrária da habitação ele propõe, tanto o controle com um discurso favorável à legislação de zoneamento, como o planejamento de novas áreas habitacionais. A habitação, organizada em unidades de vizinhança, com limite de densidade, dependeria de uma localização adequada, a imagem que ilustra o texto é de um conjunto habitacional planejado na cidade de Barcelona.

O distrito industrial ,outro exemplo de Sert, ilustra a exposição sobre o tema do trabalho. Porem como observamos, na questão do transporte está a principal diferença propositiva entre Sert e Corbusier. Concordam no diagnóstico - o congestionamento, a escassez de áreas de estacionamento, a crítica aos traçados para criação de grandes 
visuais e localização de monumentos. Porém o traçado viário resultante, para Corbusier, quando hierarquizado separa setores da cidade definidos por funções urbanas. Para Sert, como ilustrado no livro, a hierarquia viária é obtida pelas grandes obras de cruzamentos em diferentes níveis resultando nas estruturas viárias que predominam nas cidades no pós guerra com grandes viadutos e rotatórias.

Nossas análises sobre a penetração do urbanismo modernista são ainda preliminares. Procuramos nas suas manifestações mais visiveis: os projetos propostos para o concurso do Plano Piloto para Brasília, os projetos de cidade universitária, os conjuntos habitacionais projetados e construídos ,os indícios da forma como ressoam os princípios deste movimento no meio urbanístico paulistano.

A leitura dos textos escritos por Vilanova Artigas são reveladoras da uma postura política que procuram imprimir na concepção da arquitetura. A crítica que faz à proposta do Modulor de Corbusier, ${ }^{6}$ em 1950 ,denunciando a como instrumental à penetração do imperialismo tem um significado político ideológico. Conforme observa em $1982^{7}$, procurava naquele momento inaugurar um caminho peculiar ou próprio à crítica da arquitetura inserindo a em uma visão de mundo.

Em 1965, Artigas respondendo sobre a falência do movimento funcionalista, é possível perceber as expectativas e os limites da adesão ao movimento moderno como um projeto para colocar a arquitetura a serviço de sua própria "desalienação" como também a serviço do esforço geral da cultura, na transformação do homem .

No mesmo texto, mais adiante, ele observa o nexo orgânico e deliberado entre o movimento da arquitetura moderna com a sociedade industrial capitalista. "Os países subdesenvolvidos desejam a industrialização, quaisquer que sejam as suas decorrências, pois que, partindo das teses funcionalistas, seria possível o seu controle,

6 "Le Corbusier e o imperialismo"in Artigas João Vilanova , 1986, opus cit pp 55-62

7 Depoimento prestado à Sylvia Ficher em 10 de agosto de 1982 , cedido pela autora para este trabalho 
já agora para transformar o nosso mundo no qual o atraso do desenvolvimento capitalista, ou a sua convivência com o feudalismo, provoca espetáculos de miséria social muito piores. ${ }^{18}$ Nesta reflexão estaria uma das pistas para explicar a adesão ao modelo funcionalista presente em todas as propostas para o Plano Piloto de Brasilia.

Afirmamos na introdução deste trabalho que o recurso à pesquisa histórica representa uma fonte privilegiada de questionamento para a compreensão e reapropriação do presente. Esperamos com este trabalho ter fornecido algumas pistas para entender os rumos do planejamento urbano a partir dos anos sessenta.

8 Artigas, Vilanova "Uma falsa crise"in Caminhos da arquitetura,Ed Pini, 2a ed, 1986 pp 97101 


\section{Referências Bibliográficas}

AGACHE, Donat Alfred Agache. Cidade do Rio de Janeiro: extensão, remodelação, embellezamento. Paris, Ed Foyer Brésilien, 1930.

ALBUQUERQUE, Alexandre de. "Higiene da residência urbana". scp, São Paulo, 1917. conforme Campos Neto, 1999, p 204.

ANDRADE, Carlos Roberto Monteiro de. A peste e o plano. O urbanismo sanitarista do engenheiro Saturnino de Brito. Dissertação de Mestrado, FAUUSP, 2 vol, 1992.

ANDRADE, Carlos Roberto Monteiro de .Barry Parker, um arquiteto inglês na cidade de São Paulo. Tese de Doutoramento, FAUUSP, 1998.

ANDRADE, Carlos Roberto Monteiro de e LEME, Maria Cristina da Silva. "O rio Tietê: dos meandros às avenidas marginais" in II Seminário Metrópoles Latino Americanas, São Paulo, Anais, UNCRD, FAUUSP, FUPAM, 1993, v.1. ANDRADE, Oswald. Um homem sem profissão. Sob as ordens de mamãe. 2 ed Rio de Janeiro, Civilização Brasileira, 1976.

ANTONUCCI, Denise. Plano Diretor de São Paulo 1991. Avanços e Permanências. Dissertação de Mestrado, FAUUSP, 1999.

ARQUITETURA E ENGENHARIA n 42, novembro/dezembro 1956.

ARQUITETURA E ENGENHARIA n 44, março/abril 1957.

ARTIGAS, João Batista Vilanova. Caminhos da arquitetura $2^{\mathbf{a}}$ ed,São Paulo, PINI, Fundação Vilanova Artigas, 1986.

BALLANGÉ, Guy. "Joseph Stubben (1845-1936) Héritier ou fondateur”in DETHIER, Jean e GUILHEUX, Alain. La Ville, art et architecture en Europe, 1870-1993. Paris, Centre Georges Pompidou, 1994.

BENEVOLO, Leonardo. História da arquitectura moderna. $2^{\circ}$ vol, Madri, Taurus, 1963.

BIRKHOLZ, Lauro. "O ensino do planejamento territorial no Brasil”, São Paulo, 1967.

BONDUKI, Nabil. Origens da habitação social no Brasil. São Paulo, Estação Liberdade, 1998.

BOSI, Bosi. Memória de Velhos. São Paulo, T.A. Queiroz, 1979.

BRAGA, Milton Liebentritt de Almeida. O concurso de Brasilia: os sete 
projetos premiados. Dissertação de Mestrado, FAUUSP, 1999.

BRUANT, Catherine. "Donat Alfred Agache: urbanismo, uma sociologia aplicada" in RIBEIRO, Luiz Cesar e PECHMAN, Robert (org). Cidade, povo e nação: gênese do urbanismo moderno. Civilização Brasileira, 1996.

BOURDIEU, Pierre.A economia das trocas simbólicas. São Paulo, Perspectiva, 1974.

CAMPOS NETO, Cândido Malta. Os rumos da cidade: urbanismo e modernização em São Paulo. Tese de Doutoramento, FAUUSP, 1999, $2^{\circ} \mathrm{vol}$. CANDIDO ,Antonio "Alguns tópicos para a reflexão" Folha de São Paulo,29/ 11/99, Ilustrada,

CASCALDI, Carlos, ARTIGAS, João Vilanova, CUNHA, Mario Wagner Vieira, ALMEIDA, Paulo de Camargo. Futura capital federal, Brasilia, Plano piloto. Relatório apresentado à comissão julgadora do concurso para o Plano Piloto da nova capital federal. São Paulo, março 1957.

CERDA, Ildefonso. La Théorie Générale de l'Urbanization. Paris, Seuil, 1979. CINTRA, João Florence de Ulhôa. "Projeto de uma avenida circular constituindo perímetro de irradiação". $\mathrm{n}^{\circ} 24$ Boletim do Instituto de Engenharia, 1924.

CINTRA, João Florence de Ulhôa. "Sugestões para orientação do estudo de um plano geral de remodelação e expansão da cidade de Recife". Prefeitura Municipal de Recife, A Recife, Arquivos ${ }^{\circ}$ 10, 1943.

COHEN, Jean Louis. "Presentation: les visions métropolitaines d'Eugène Hénard" in Henard, Eugène Les transformations de Paris. Paris, L'Enquerre, 1982.

"Congrès Internationaux d'Architecture Moderne". Coleção Documentos del siglo veint, Buenos Aires, Artes Gráficas Alfonso Ruiz, 1957.

DAHER, Luis Carlos. Flavio de Carvalho: arquitetura e expressionismo. São Paulo, Projeto, 1982.

DAL CO,Francesco. "De los Parques a la region" in CIUCCI, Giorgio et alti $L a$ ciudad americana. Barcelona, Gustavo Gili, 1975.

DEAK, Csaba e SHIFFER, Sueli (orgs). O Processo de urbanização no Brasil. São Paulo, FUPAM.

FELDMAN, Sarah. Planejamento e zoneamento São Paulo 1947- 1972. Tese de doutorado. FAUUSP, 1996. 
FICHER, Sylvia. Ensino e profissão: o curso de engenheiro-arquiteto da Escola Politécnica de São Paulo. Tese de doutoramento, Departamento de História FFLCHUSP, 1989.

FRAMPTON, Keneth. História critica da arquitetura moderna. São Paulo, Martins Fontes, 1997.

FREIRE, Victor da Silva. "A planta de Belo Horizonte" in Revista Politécnica $n^{0} 52,1916$.

FREIRE, Victor da Silva. "Os Melhoramentos de São Paulo" in Revista Politécnica. São Paulo, n 33 fev/mar 1911.

FREIRE, Victor da Silva. "A Cidade salubre" in Revista Politécnica n ${ }^{\circ} 48$, out/ nov 1914.

FREIRE, Victor da Silva. "A planta de Belo Horizonte ( a propósito da cidade salubre)" in Revista Politécnica $\mathrm{n}^{\circ}$ 52, 1916.

FREIRE, Victor da Silva. "Códigos Sanitários e Posturas Municipais sobre habitações. .Um capitulo de urbanismo e economia nacional" in Boletim do Instituto de Engenharia $\mathrm{n}^{\circ} 3$, fevereiro 1918.

FREIRE, Victor da Silva. "O futuro das Concessões Municipais na cidade de São Paulo". in Revista Politécnica n .60, 1919.

FREIRE, Victor da Silva. "Os Melhoramentos de São Paulo" in Revista Politécnica $\mathrm{n}^{\circ}$ 33, 1911.

GATAI, Zélia. Anarquistas, graças a Deus. 2a ed, São Paulo, Record, 1980.

GAUDIN, Jean Pierre. "Savoirs, savoir-faire et mouvement de professionalisation dans l'urbanisme au début de siécle". Sociologie du Travail $\mathrm{n}^{\circ} 21987$.

GAUDIN, Jean Pierre. Dessein de Ville, Paris, L'Harmattan, 1991.

IBEC "Programa de Melhoramentos Públicos para a cidade de São Paulo.

Program of Public Improvements", Robert Moses, diretor de estudos, New York City, novembro 1950.

GUNN, Philip Oliver. Frank Loyd Wright e a passagem para o fordismo.

Revista Espaço \& Debates n 28,1989.

KOWARICK, Lucio (org). As lutas sociais e a cidade. São Paulo: passado e presente. Rio de Janeiro, Paz e Terra, 1988.

LAMPARELLI, Celso. "Joseph Louis Lebret e a pesquisa urbanos regional no Brasil: crônicas tardias ou história prematura". in Espaço \& Debates n $^{\circ} 37$, 
1994

LE CORBUSIER. "La ville radieuse élements d'une doctrine d'urbanisme pour l'equipement de la civilisation machiniste". Paris, Vincent, Fréal \& Cie, [1933], 1964.

LE MAÎTRE D'OEUVRE. Revue Française d'Urbanisme. Numéro spécial sur le Rio de Janeiro, n 33, avril/mai 1929.

LEÃO, Mario Lopes. “O Metropolitano de São Paulo”. PMSP, São Paulo, 1945.

LEBRET, Louis Joseph. Guide Pratique de l'enquete sociale. vol III,

L'enquête urbaine l'analyse du quartier et de la ville. Paris, PUF, 1955.

LEBRET, Louis Joseph. "Princípios para a ação". Suplemento Especial Folha de São Paulo, 1968.

LEME, Maria Cristina da Silva. Planejamento em São Paulo. Dissertação de mestrado, FAUUSP, 1982.

LEME, Maria Cristina da Silva e PACHECO, Regina S.V. "A questão fundiária, imobiliária e os serviços urbanos: conceitos e referênciais teóricos em teses e dissertações recentes". Espaço \& Debates, n 28. São Paulo, NERU, 1989.

LEME, Maria Cristina da Silva. Revisão do Plano de Avenidas: 1930 um estudo sobre o planejamento urbano em São Paulo. Tese de Doutoramento.

FAUUSP, 1990.

LEME, Maria Cristina da Silva. “A formação do pensamento urbanístico em São Paulo no início do século". Espaço \& Debates n 34, 1991.

LEME, Maria Cristina da Silva. "As portas da cidade moderna” in Arquitetura e Urbanismo $\mathrm{n}^{\circ}$ 64, fevereiro/março 1996.

LEME, Maria Cristina da Silva. "A formação do urbanismo como disciplina e profissão: São Paulo na primeira metade do século XX". in RIBEIRO, Luiz Cesar e PECHMAN, Robert (org) Cidade, povo e nação : gênese do urbanismo moderno. Civilização Brasileira, 1996.

LEME, Maria Cristina da Silva. "La formazione dell 'urbanistica come disciplina e professione a San Paolo del Brasile 1892-1957”. in Storia Urbana $\mathrm{n}^{\circ} 78$,jan/mar 1997.

LEME, Maria Cristina da Silva (coordenadora). Urbanismo no Brasil 18951965. São Paulo, NOBEL, FAUUSP, FUPAM, 1999.

LEMOS, Carlos. A alvenaria burguêsa. São Paulo, Nobel, 1985. 
LEWIS, Nelson P. The planning of the modern city. A review of the principles governing city planning. $2^{\text {nd }}$ New York, John Wiley \& Sons, Inc., 1923.

LILLE, Laurent Coudroy. "Urbanisme" in Urbanisme. Paris, janeiro, 1999.

LODI, Carlos. "Planejamento Geral" in Ciclo de Conferências da Secretaria de Obras. São Paulo, Gráfica Municipal, 1949.

LODI, Carlos. "Situação do planejamento da cidade de São Paulo em 1960". in Revista Engenharia $\mathrm{n}^{\circ}$ 226, setembro 1961.

MACHADO, Antonio de Alcântara. Novelas Paulistanas. 4a ed. Rio de Janeiro, Livraria José Olympo, 1976.

MAGRI, Suzana e TOPALOV, Christian. "De la cité jardin à la ville rationalisée: un tournant du projet réformateur" Révue Française de Sociologie $\mathrm{n}^{\circ} 28,1987$.

MAIA, Francisco Prestes e CINTRA, João Florence de Ulhôa."Um problema actual: os grandes melhoramentos de São Paulo". in Boletim do Instituto de Engenharia, São Paulo, $n^{\circ} 26 / 27$ outubro 1924 a março $1925 ; n^{\circ} 28$ março a junho 1925, n 29 julho a outubro 1925; nº 31 março a junho 1926.

MAIA, Francisco Prestes. Introdução ao estudo de um Plano de Avenidas para a cidade de São Paul. São Paulo, Melhoramentos, 1930.

MAIA, Francisco Prestes. O Zoneamento Urbano São Paulo. Edições Amigos da Cidade, 1936.

MAIA, Francisco Prestes. Os melhoramentos de São Paulo. São Paulo, Prefeitura Municipal de São Paulo, 1945.

MAIA, Francisco Prestes. "O Programa Norte Americano de Melhoramentos para São Paulo."'in Digesto Econômico, abril, 1951.

MAIA, Francisco Prestes. "Arquitetura e arte". in Revista de Engenharia Mackenzie, $\mathrm{n}^{\circ}$ 126, 1955.

MARTINS, Carlos Alberto Ferreira. "Le Corbusier en la conquista de America: ciudad y paisaje en los proyectos sudamericanos y el embate contra el SFU'.in Seminário Internacional As origens das politicas modernas na América Latina 1900-1945 IPPUR, Rio de Janeiro, agosto/setembro 1994.

MARQUES, Sônia. Les professions de l'urbanisme au Bresil. Thèse de Doctorat. École des Hautes Études en Sciences Sociales, s/d.

MELLO, Luiz Ignácio de Anhaia. "Problemas de Urbanismo: mais uma contribuição para o calçamento". Revista Politécnica, n 83, 1927. 
MELLO, Luiz Ignácio de Anhaia. "Um grande urbanista francês: Donat Alfred Agache." Revista Politécnica, n 85/86, 1928.

MELLO, Luiz Ignácio de Anhaia. "A cidade problema de governo." Boletim do Instituto de Engenharia $n^{\circ} 43$, dezembro de 1928.

MELLO, Luiz Ignácio de Anhaia. "O recreio activo e organizado das cidades modernas." Boletim do Instituto de Engenharia n $\mathrm{n}^{\circ}$ 47, abril 1929.

MELLO, Luiz Ignácio de Anhaia. "A verdadeira finalidade do urbanismo." in Boletim do Instituto de Engenharia, $\mathrm{n}^{\circ}$ 51. São Paulo, agosto 1929.

MELLO,Luiz Ignácio de Anhaia "Regulamentação dos serviços de utilidade pública" in Boletim do Instituto de Engenharia $n^{\circ} 59$ abril 1930 MELLO,Luiz Ignácio de Anhaia "Regulamentação dos serviços de utilidade pública" in Boletim do Instituto de Engenharia $\mathrm{n}^{\circ} 60$ maio 1930.

MELLO, Luiz Ignácio de Anhaia. "A Sociedade Amigos da Cidade e sua função no quadro urbano" in Boletim do Instituto de Engenharia $\mathrm{n}^{\circ} 115$, junho 1935.

MELLO, Luiz Ignácio de Anhaia. "Engenharia e urbanismo - profissão e personalidade" in Revista de Engenharia Mackenzie, $\mathrm{n}^{\circ} 124,125$.

MELLO, uiz Ignácio de Anhaia. "Urbanismo e Organização Administrativa" in Revista Engenharia n 38 outubro de 1945.

MELLO, Luiz Ignácio de Anhaia. "Um plano regulador para o município de São Paulo. Elementos constitutivos do plano." Revista Engenharia ${ }^{\circ} 41$, janeiro 1946.

MENDONÇA, Adolpho Luis Machado. "A trajetória dos técnicos da SAGMACS." in Anais V Encontro Nacional ANPUR, Belo Horizonte, 1993. MEYER, Regina. Metrópole e Urbanismo São Paulo, anos 50. Tese de Doutoramento, FAUUSP, 1991.

MÓDULO, $\mathrm{n}^{\circ} 8$, julho 1957.

MUSÉE SOCIAL Mémoires et Documents $\mathrm{n}^{\circ} 11,1912$.

OLIVEIRA, Francisco de. "O Estado e o urbano." Espaço \& Debates n 6 , 1982.

PAES, Célia da Rocha. Bexiga e seus território.s Dissertação de Mestrado, FAUUSP, 1999.

PELLETIER, Denis. Economie et Humanisme .De l'utopie communautaire au combat pour le tiers monde 1941-1966. Paris, Ed du CERF, 1996. 
PONTUAL, Virginia. "O saber urbanístico no Governo da Cidade: uma narrativa do Recife das décadas de 1930 a 1950. Tese de Doutoramento, FAUUSP, 1998.

PORTINHO, Carmem. "O ensino do urbanismo." in Revista Municipal de Engenharia, Rio de Janeiro, julho 1934.

REIS FILHO, Nestor Goulart. Aspectos da história da engenharia civil em São Paulo 1860-1960. São Paulo, Companhia Brasileira de Projetos e Obras/CBPO, Livraria Kosmos Editora, 1989.

RONILK, Raquel. A cidade e a lei. São Paulo, Studio Nobel, FAPESP, 1997. s.n.a "O Projecto Alexandre Albuquerque "Revista de Engenhari, $1^{\circ}$ Volume, junho de 1911/maio de 1912.

s.n.a "O Relatório Bouvard." Revista de Engenharia, $1^{\circ}$ volume, junho de 1911/maio de 1912.

s.n.a "Projecto Freire Guilhem." Revista de Engenharia, $1^{\circ}$ volume, junho de 1911/maio de 1912.

s.n.a "Projecto Samuel das Neves." Revista de Engenharia, $1^{\circ}$ volume, junho de 1911/maio de 1912.

s.n.a. "As grandes Avenidas e os Melhoramentos." in Revista de Engenharia, $1^{\circ}$ volume, junho 1912.

s.n.a "Uma colaboração dos alunos da Faculdade de Arquitetura para a solução do problema". Habitat n' 16, 1954.

SAES, Flávio Azevedo Marques de. A grande empresa de serviços públicos na economia cafeeira. São Paulo, Hucitec, 1986.

SAMPAIO, Maria Ruth do Amaral. "O papel da iniciativa privada na formação da periferia paulistana" in Espaço \& Debates, $\mathrm{n}^{\circ} 37$.

SANTOS, Cecília Rodrigues et altrii. "Le Corbusier e o Brasil." São Paulo, Tessela, Projeto, 1897.

SANTOS, Antonio da Costa. Compra e venda de terra e água e um tombamento na primeira sesmaria da freguesia de Nossa Senhora da Conceição das Campinas do Mato Grosso de Jundiai 1732-1992. Tese de doutorado, FAUUSP, 1999.

SÃO PAULO, Departamento de Urbanismo da Prefeitura Municipal, Secretaria de Obras, Prefeitura Municipal de São Paulo, "Planejamento 1957/1961." São Paulo, 1961. 
SCHERER, Rebecca. "Apresentação" in LE CORBUSIER A Carta de Atenas. EDUSP/Hucitec, 1986.

SCHERER, Rebecca. Descentralização e planejamento urbano no municipio de São Paulo. Tese de doutorado. FAUUSP, São Paulo, 1987.

SERT, José Luis. "Cant our cities survive? an abc of urban problems, their analysis, their solutions based on the proposals formulated by the CIAM." Cambridge, Harvard Press, 1944.

SILVA, Antônio de Moraes. Dicionário da lingua portuguesa. Lisboa, Lacerdina, 1813.

SILVA TELLES, Augusto Carlos. Melhoramentos de, São Paulo. Escolas Salesianas.

SILVA, Janice Theodoro. São Paulo 1554 -1880 Discurso Ideológico e organização espacial. São Paulo, Editora Moderna, 1984.

SIMÕES Jr, José Geraldo. O Setor de Obras Públicas e as origens do urbanismo na cidade de São Paulo .Dissertação de mestrado. EAESP FGV, 1990.

SIMÕES Jr, José Geraldo. Anhangabaú: história e urbanismo. Tese de doutoramento. FAUUSP, 1995.

SOMEKH, Nadia. A (des) verticalização de São Paulo. Dissertação de mestrado. FAUUSP, 1987.

SOMEKH, Nadia. A cidade vertical e o urbanismo modernizador. p.40. São Paulo, EDUSP, Nobel, FAPESP, 1997.

TAFURI, Manfredo e DAL CO, Francesco. Architecture Contemporaine., Paris, Gallimard/Electa 1991.

TOLEDO, Benedito Lima de. Prestes Maia e as Origens do Urbanismo Moderno. São Paulo, Empresa das Artes, 1996.

TOPALOV, Christian. "Os saberes sobre a cidade: tempos de crise?" in Espaço \& Debates n 34, 1991.

TOPALOV, Christian. "De la planification à l'ideologie, naissance d'un nouveau paradigme de l'action sur la ville et l'habitat? 'mimeo, 1992. VILLAÇA, Flávio. A estrutura territorial da metrópole sul brasileira. Tese Doutoramento. Departamento Geografia FFLCH USP, 1979. 